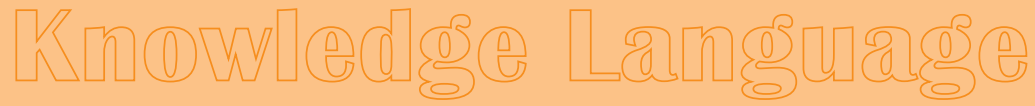 \\ Communicarting «
}

\section{La sabiduría de Mnemósine}

Ensayos de historia

de la lingüística

José Luis Mendívil Giró María del Carmen Horno Chéliz (eds.)

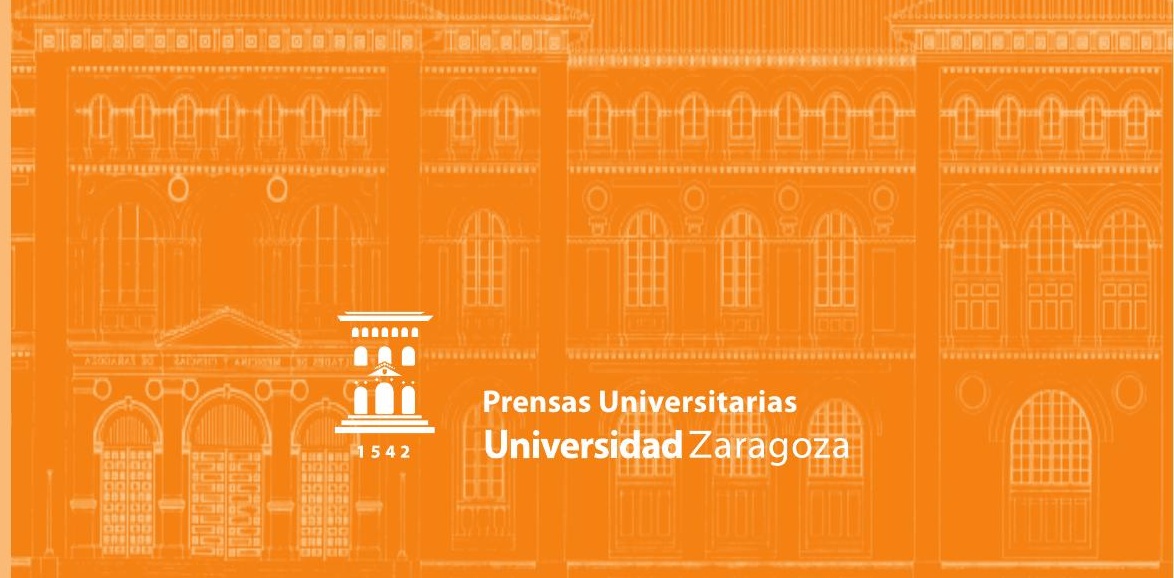





\section{LA SABIDURÍA DE MNEMÓSINE}

Ensayos de historia de la lingüistica ofrecidos a José Francisco Val Álvaro 


\section{Knowledge Language Communication \\ Conocimiento Lenguaje Comunicación}

\section{Editores}

José Francisco Val Álvaro (Universidad de Zaragoza)

María del Carmen Horno Chéliz (Universidad de Zaragoza)

\section{Comité editorial}

Ignacio Bosque (Universidad Complutense de Madrid), José M.a Brucart (Universidad Autónoma de Barcelona), João Costa (Universidad de Lisboa, Portugal), Violeta Demonte (Universidad Autónoma de Madrid), Victoria Escandell (Universidad de Alcalá), Salvador Gutiérrez (Universidad de León), Ángel López García (Universidad de Valencia), Juan Uriagereka (Universidad de Maryland, EE. UU.), Jacqueline Guéron (Universidad París III, Francia)

\section{Secretario editorial}

José Luis Mendívil

Departamento de Lingüística General e Hispánica

Facultad de Filosofía y Letras

Universidad de Zaragoza

Pedro Cerbuna, 12

E-50009 Zaragoza

jlmendi@unizar.es 


\title{
LA SABIDURÍA DE MNEMÓSINE Ensayos de historia de la lingüistica ofrecidos a José Francisco Val Álvaro
}

\author{
José Luis Mendivil Giró \\ Maria del Carmen Horno Chéliz \\ (eds.)
}


La SABIDURÍA de Mnemósine : ensayos de historia de la lingüística ofrecidos a José Francisco Val Álvaro / José Luis Mendívil Giró, María del Carmen Horno Chéliz (eds.). - Zaragoza : Prensas Universitarias de Zaragoza, 2012

274 p. ; $22 \mathrm{~cm}$. - (Knowledge Language Communication = Conocimiento Lenguaje Comunicación ; 4)

ISBN 978-84-15538-09-7

1. Val Álvaro, José Francisco-Homenajes. 2. Lingüística-Historia MENDÍVIL GIRÓ, José Luis

HORNO CHÉLIZ, María del Carmen

929Val Álvaro, José Francisco

81(091)

Cualquier forma de reproducción, distribución, comunicación pública o transformación de esta obra solo puede ser realizada con la autorización de sus titulares, salvo excepción prevista por la ley. Diríjase a CEDRO (Centro Español de Derechos Reprográficos, www.cedro.org) si necesita fotocopiar o escanear algún fragmento de esta obra.

(C) Los autores

(C) De la presente edición, Prensas Universitarias de Zaragoza

1. ${ }^{\text {a }}$ edición, 2012

Prensas Universitarias de Zaragoza. Edificio de Ciencias Geológicas, cl Pedro Cerbuna, 12 50009 Zaragoza, Espańa. Tel.: 976761 330. Fax: 976761063

puz@unizar.es http://puz.unizar.es

U17e Esta editorial es miembro de la UNE, lo que garantiza la difusión y comercialización de sus publicaciones a nivel nacional e internacional.

Impreso en España

Imprime: Servicio de Publicaciones. Universidad de Zaragoza

D.L.: Z-640-2012 
A Pepe 



\section{ÍNDICE}

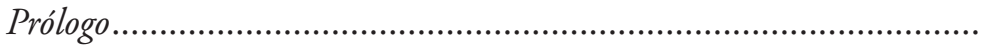

Introducción

José Luis Mendívil y María del Carmen Horno

PARTE I

Historia DE LA LINGÜÍSTICA: PERSPECTIVAS Y PARADIGMAS

Acerca del imaginario lingüistico del pasadolatrás Daniel H. Cabrera Altieri

Una visión foucaultiana sobre la historia reciente de la lingüistica Ángel López García

¿ ¿Si Coseriu viviera, sería cognitivista»? Exploraciones sobre los antecedentes lingüísticos históricos de las bases epistemológicas de la lingüistica cognitiva

Iraide Ibarretxe-Antuñano

El concepto de lengua en la lingüistica reciente: breve reflexión sobre un malentendido duradero

José Luis Mendívil Giró 
El nacimiento de las escrituras y los orígenes de la reflexión lingüistica Jesús Tusón Valls.

"El món és una al.legoria». Nombrar lo metalingüistico en la poesía de Pere Gimferrer

Túa Blesa

\section{PARTe II}

HisTORIA DE LA GRAMÁTICA: NIVELES, UNIDADES Y TRADICIONES

La domesticación de un salvaje: breve repaso histórico a la fonología de la entonación

Javier Simón Casas

Noventa años de descripción de la morfología léxica española: tratados de formación de palabras en español (1920-2010)

David Serrano-Dolader

Aspectos de la sufijación en español

Félix Tadeo Monge Casao

El elemento cero como recurso morfológico en el modelo Item and Arrangement

Jesús Pena.

El significado procedimental: rutas hacia una idea

Manuel Leonetti y M. Victoria Escandell

Entre Kufa y Basora: nombres, verbos y raices

Antonio Fábregas

En el Principio era el verbo. La categoría verbal en las obras de PortRoyal

María del Carmen Horno Chéliz 


\author{
PARTE III \\ LA EVOLUCIÓN DE LA LINGÜÍSTICA APLICADA: \\ COMPARACIÓN, ENSEÑANZA Y APRENDIZAJE DE LENGUAS
}

Listas de lenguas en el siglo XVIII. Ideología y taxonomía en los vocabularios poliglotos de Pallas y Hervás (1787)

Juan Carlos Moreno Cabrera

La actuación lingüistica de los misioneros españoles "arabistas» en el siglo XVI

Federico Corriente.

Dos lenguas y una mente. Historia de la influencia interlingüistica en la adquisición de segundas lenguas

Alberto Hijazo Gascón

Las actividades de práctica gramatical en la enseñanza de español como lengua extranjera

Enrique Aletá Alcubierre

La calidad de la descripción en la pedagogía de modelo de La parfaicte méthode pour entendre, escrire, et parler la langue Espagnole (1596) Covadonga López Alonso

Notas sobre la sintaxis de Doergangk

Emilio Ridruejo Alonso

La enseñanza de la lengua española en el Plan Villalobos (1934):

Caracteristicas, fundamentos y proyección posterior

María Antonia Martín Zorraquino 



\section{PRÓLOGO}

Hay muchas maneras de estar en la vida. Hay personas que no quieren ser el epicentro de su propia existencia, sino que se sitúan en la misma junto a los demás, con ellos y no frente a ellos. Pepe Val es una de esas (raras) personas.

También hay personas que se comportan de distinta manera cuando están entre sus familiares y amigos o cuando están con sus alumnos, sus colegas y colaboradores. Pepe Val no es de esas (abundantes) personas.

Si es cariñoso, solidario y compasivo con su familia y con sus amigos, también lo es con sus alumnos y con sus colegas. Nosotros hemos tenido el privilegio de ser sus alumnos, sus colegas y, por supuesto, sus amigos, y por eso podemos afirmarlo.

Ninguno de nosotros dos estaría donde está (y estamos muy contentos de dónde estamos) sin su apoyo desinteresado, sin su inteligencia y sus conocimientos y, por supuesto, sin su cariño incesante, tozudo, incondicional.

También de él hemos aprendido que el funcionario público no solo está para engrosar su currículo y perpetuar su (vana) gloria, sino para servir a la Universidad y a la sociedad que nos mantiene, sin escatimar esfuerzos y sin demandar privilegios.

Por todo ello hemos impulsado este volumen en su honor, y porque sabemos que un lingüista de raza apreciaría superlativamente un libro de lingüística como el mejor regalo para su sesenta cumpleaños.

No nos ha sido nada difícil convencer al resto de autores que integran esta obra, a quienes agradecemos muy sinceramente su complicidad y que 
compartan con nosotros, y con Pepe, su talento y su saber. Podrían haber sido muchos más, pero hemos querido invitar, dentro de los límites de lo editorialmente razonable, a aquellos investigadores que forman parte de su círculo más estrecho, a aquellos a los que admira, a aquellos a los que ha formado, o a aquellos a los que simplemente quiere mucho. Afortunadamente para él, muchos de los autores se incluyen en más de una categoría de las anteriores.

Mnemósine es la diosa de la memoria y la memoria es uno de los fuertes de nuestro maestro. De entre sus múltiples intereses en el ámbito de la lingüística, la mirada al pasado de nuestra disciplina, el respeto por los gigantes (y algún cabezudo) sobre los que nos apoyamos siempre ha ocupado un lugar central. No solo ha dedicado parte de su investigación y afanes a la historia y evolución de las ideas lingüísticas, sino que nos obligó, cuando nos dirigía la tesis doctoral, a leer todo lo que se había escrito antes, con la sabia advertencia de que ya había demasiada gente inventando la misma rueda y de que es mejor esforzarse por comprender lo que aún no comprendemos que en trillar los caminos ya recorridos, aunque esto suela ser más fácil.

E iluminar parte de esos caminos recorridos para aprender del tránsito pasado a trazar la ruta hacia el futuro es precisamente el objetivo de este libro que, además de un homenaje gozoso, es también una contribución a la historia de las ideas sobre el lenguaje, sobre las lenguas, sobre la lingüística.

José Luis Mendívil Giró María del Carmen Horno CHÉLIz 


\title{
INTRODUCCIÓN
}

\author{
José Luis Mendívil Giró \\ María del Carmen Horno Chéliz \\ (Universidad de Zaragoza)
}

Mnemósine es la diosa de la memoria.

De su encuentro amoroso con Zeus

dio a luz a las musas,

que serán las inspiradoras de las ciencias y de las artes.

Una vez más, la mitología clásica expresa de forma novelada una importante reflexión que hoy más que nunca es preciso recordar: para que haya arte y para que haya ciencia (esto es, para que el ser humano pueda ser creativo), hace falta una inspiración que se base en dos ingredientes principales: un don (divino, si se quiere, del que da cuenta la aportación de Zeus) y un buen conocimiento de lo que hasta ese momento se ha hecho en la disciplina en la que se trabaja (esto es, la aportación de Mnemósine). Sin cualquiera de esos dos ingredientes, la ciencia no podría avanzar.

La capacidad «divina» de hacerse las preguntas adecuadas, de reconocer las herramientas metodológicas más útiles y de sacar conclusiones ajustadas a los datos se nutre, en ocasiones, de un talento innato en el científico. Pero dicho talento natural, incluso cuando existe de manera superlativa, se ha de enriquecer con la práctica científica y con la lectura de los hallazgos de los demás. En caso contrario, se puede desaprovechar el talento en vano. Como no puede ser de otra manera, en el ámbito de la lingüística resulta absolutamente necesario que el devenir diario de la investigación se 
complemente con los momentos de reflexión sobre lo que otros dijeron acerca de problemas similares. De esta convicción surge la necesidad de seguir realizando estudios de historiografía lingüística y darlos a conocer en obras como la que el lector tiene entre sus manos. Porque la ciencia, aunque parezca hecha de momentos intensos de creación individual, es, en realidad, la obra más colectiva y cooperativa de todas las que los humanos llevan a cabo.

El volumen que presentamos se estructura en tres grandes partes. En primer lugar (Historia de la lingüística: perspectivas y paradigmas), se proponen reflexiones de amplia perspectiva sobre los paradigmas, modelos y tipos de aproximación al lenguaje humano. La segunda parte (Historia de la gramática: niveles, unidades y tradiciones) comprende aportaciones que se centran en aspectos históricos de la descripción gramatical (fonología, morfología, sintaxis, semántica y pragmática), bien centrándose en niveles y unidades, bien en tradiciones u obras concretas. La tercera parte (La evolución de la lingüística aplicada: comparación, enseñanza y aprendizaje de lenguas) agrupa, por fin, trabajos centrados en la historia y evolución de obras y conceptos orientados a la práctica o al estudio de los procesos de enseñanza y aprendizaje de lenguas.

Los contenidos de cada contribución son los siguientes:

\section{Parte I. Historia de la lingüistica: perspectivas y paradigmas}

Daniel Horacio Cabrera Altieri («Acerca del imaginario lingüístico del pasado/atrás») propone una reflexión sobre lo que la cultura occidental valora el pasado y su recuerdo. La lectura de estas páginas ha de motivar al lector a una reflexión sobre el modo en el que en nuestra cultura se ha gestado esta relación y cómo culturas distintas a la nuestra pueden concebirla de otro modo.

ÁNGEL López GARcía («Una visión foucaultiana sobre la historia reciente de la lingüística») reflexiona sobre el modo en el que se presentan en los libros de historiografía las diversas escuelas lingüísticas y cómo dicha presentación responde a un modo particular de entender la historia de la ciencia.

Iraide Ibarretxe Antuñano (“Si Coseriu viviera, sería cognitivista? Exploraciones sobre los antecedentes lingüísticos históricos de las bases epistemológicas de la lingüística cognitiva») ofrece una completa presenta- 
ción de los orígenes de la lingüística cognitiva, con el objetivo de mostrar cómo las distintas teorías no constituyen, en general, marcos contradictorios, sino más bien complementarios, con múltiples relaciones entre ellos.

José Luis Mendívil Giró («El concepto de lengua en la lingüística reciente: breve reflexión sobre un malentendido duradero») continúa en esta línea de compatibilidad de modelos lingüísticos, advirtiendo de que en realidad en muchas ocasiones las discrepancias teóricas entre lingüistas están basadas en que tienen distintos objetos de estudio. Efectivamente, pese a que todos ellos dicen estudiar las lenguas humanas, las abordan desde concepciones diferentes de qué naturaleza última tienen estas.

Jesús Tusón («El origen de la escritura y la historia de la lingüística») realiza una intensa revisión del origen de la escritura y de lo que la aventura de la supuestamente imposible invención de la escritura revela sobre la naturaleza del lenguaje humano.

TÚa Blesa ("El món és una al.legoria. Nombrar lo metalingüístico en la poesía de Pere Gimferrer») se sumerge en la tradición de la aproximación estética y poética al lenguaje a través de un análisis de la visión del mundo como libro escrito en la poesía de Gimferrer.

Parte II. Historia de la gramática: niveles, unidades y tradiciones

Javier Simón Casas («La domesticación de un salvaje: una revisión historiográfica sobre la fonología de la entonación») revisa el origen, motivación y dificultades del estudio de la entonación como un fenómeno analizable empírica y sistemáticamente.

David Serrano Dolader ( Noventa años de descripción de la morfología léxica española: tratados de formación de palabras en español [1920-2010]») propone una informada revisión bibliográfica de las fuentes esenciales para el estudio de la morfología léxica del español.

Félix Tadeo Monge Casao («Aspectos de la sufijación en español»). Este artículo, rescatado de la RSEL para esta ocasión, representa una valoración crítica de los principales hitos en el estudio de la sufijación de la lengua espańola.

Jesús Pena («Origen y aplicación del morfo cero en el análisis morfémico») aborda el surgimiento y desarrollo del concepto de morfo cero en la lingüística estructural y muestra las dificultades de tal noción para el 
mantenimiento de un modelo de descripción morfológica basado en la aproximación de tipo Item and Arrangement.

Manuel Leonetti y Victoria Escandell ( $E$ El significado procedimental: historia de una idea») proponen una revisión de la emergencia y desarrollo del concepto de significado procedimental, junto con una valoración de su impacto en la lingüística presente y del futuro inmediato.

Antonio FÁbregas («Entre Kufa y Basora: nombres, verbos y raíces») nos lleva al siglo octavo para retomar una controversia sobre la nominalización que ha continuado en el ámbito de la sintaxis actual hasta nuestros días. Aplicando modelos y herramientas de última generación concluye que la vieja controversia entre gramáticos del árabe se hubiera resuelto con un justo empate.

María del Carmen Horno Chéliz («En el Principio era el verbo. La categoría verbal en las obras de Port-Royal») repasa la definición de la categoría verbal en las obras de los maestros racionalistas y reflexiona sobre el modo en el que dicha definición se puede relacionar con problemas vigentes en la lingüística actual.

Parte III. La evolución de la lingüistica aplicada: comparación, enseñanza y aprendizaje de lenguas

Juan Carlos Moreno Cabrera («Listas de lenguas en el siglo XviII. Ideología y taxonomía en los vocabularios políglotos de Pallas y Hervás [1787]») propone un examen comparativo de dos muestras del género de las listas de lenguas y de palabras que en el siglo XviII constituye uno de los fundamentos de la eclosión de la lingüística histórica y comparada del siglo posterior.

Federico Corriente («La actuación lingüística de los misioneros "arabistas" del siglo XVI») examina la obra de autores comisionados por la Iglesia para evangelizar en lengua árabe a la población musulmana tras la finalización de la Reconquista, lo que representa un capítulo esencial en la historia del arabismo español.

Alberto Hijazo («Dos lenguas y una mente. La influencia interlingüística a lo largo de la historia») relata el discurrir de la aproximación al fenómeno de la influencia interlingüística e introduce los problemas actuales y las perspectivas de desarrollo de la investigación sobre cómo se relacionan e influencian entre sí dos o más lenguas en la mente de un individuo. 
Enrique Aletá Alcubierre («Las actividades de gramática en la enseñanza de español como lengua extranjera») propone un análisis crítico e histórico de las diversas modalidades de actividades docentes enfocadas a la enseñanza de la gramática del español como lengua extranjera en el contexto de las diversas metodologías generales de la enseñanza de lenguas segundas.

Covadonga López Alonso ( $«$ La calidad de la descripción gramatical en La parfaicte méthode pour entendre, escrire, et parler la langue Espagnole [1596]») analiza la tipología y perfil de la descripción gramatical en la obra atribuida a Nicolas Charpentier dentro del contexto histórico y científico de la enseñanza de lenguas en general y en el siglo Xviı en particular.

Emilio Ridruejo ( Notas sobre la sintaxis de Doergangk») aborda la estructura e influencias en la obra sobre el español de Heinrich Doergangk en el contexto histórico de su momento y en estrecha comparación con las obras del mismo autor sobre las lenguas italiana y francesa.

M. a Antonia Martín Zorraquino («La enseñanza de la lengua española en el Plan Villalobos (1934): características, fundamentos y proyección») explora la estructura y fundamentos del llamado «Plan Villalobos» de reforma de la educación durante la Segunda República, centrándose especialmente en la enseñanza de la lengua española y en la proyección del mismo en el desarrollo posterior en el sistema educativo español. 

PARTE I

\section{HISTORIA DE LA LINGÜÍSTICA: PERSPECTIVAS Y PARADIGMAS}





\title{
ACERCA DEL IMAGINARIO LINGÜÍSTICO DEL PASADO/ATRÁS
}

\author{
Daniel H. Cabrera Altieri \\ (Universidad de Zaragoza)
}

\begin{abstract}
pasado, -a 1 Participio adjetivo de PASAR: 'Volver la vista a lo pasado'. Se aplica especialmente a un nombre de tiempo para referirse al transcurrido inmediatamente antes de aquel en que se está: 'La noche pasada' [...].

atrás 1 adv. Hacia la parte que está detrás: 'Echarse atrás. Marcha atrás'. 2 Se empela equivaliendo a detrás, con o sin preposición, para referirse al lugar que está a espaldas del que habla o de la cosa que se considera o al ocupado por una cosa que está después de otra en una serie en movimiento o en el tiempo: 'Hizo andar el coche hacia atrás. El viento venía de atrás'. La preposición a se suprime: 'Dar un paso atrás' [...].
\end{abstract}

María Moliner, Diccionario de uso del español

\section{Introducción}

Tenemos recuerdos del pasado y no conocemos el futuro; sin embargo, consideramos el pasado como lo que quedó atrás y el futuro como lo que está ante nosotros. Hemos visto el pasado y podemos seguir mirándolo pero no vemos el futuro. Alguien que viniera de afuera de Occidente podría llamar la atención acerca de la rareza de la relación entre lo conocido que se ubica a las espaldas y lo que aún no se conoce señalado hacia adelante. Máxime cuando la luz, la visibilidad y la mirada consti- 
tuyen el paradigma del conocimiento. A ello remiten las etimologías de palabras como "teoría», "especulación», «evidencia», "contemplación», «reflexión», entre otras. También las metáforas y expresiones como "punto de vista», "la perspectiva», "visto desde otro ángulo», "lo visible», «lo invisible», "la luz de la razón». Entender es iluminar, hacer visible o ver de otra manera, y la verdad, ámbito por excelencia del pensamiento, es des-ocultar, traer a la luz lo oculto, lo que estaba ahí pero no era percibido. El pasado se conoce pero se ubica a las espaldas, del futuro no se sabe nada pero se ubica enfrente. No en toda cultura el lenguaje remite a esta relación que la modernidad occidental ha consagrado como el imaginario del progreso y el desarrollo. El presente texto constituye un conjunto de notas que consideran comparativa y brevemente el imaginario moderno del pasado. ${ }^{1}$

\section{El imaginario occidental: del espacio al tiempo}

El «pasado» es lo que ha sucedido, es lo que queda y donde queda al "pasar» de un sitio o situación a otro. El léxico parte de la experiencia antropológica del caminante que en su andar deja a sus espaldas lo que ya ha recorrido: el espacio y sus objetos. La experiencia del movimiento espacial ha moldeado el imaginario de la experiencia del tiempo como travesía del pasado al futuro. "Lo pasado, pisado» dice el refranero anudando la experiencia espacial con una semántica temporal. Así el «pasado»aparece como un "nombre de tiempo» que refiere a lo que queda detrás, «al lugar que está a espaldas del que habla». Atrás: "hacia la parte que está o queda a las espaldas de uno" (DRAE) y que se opone a lo que aparece delante de la vista en el avanzar — una cosa «tras» otra - permitiendo imaginar el «trans», lo que está más allá o incluso, al otro lado de. El pasado aparece como el atrás, lo que se deja, el lugar del olvido. En consonancia con ello, en la cultura Occidental el «atrás» está resguardado por la prohibición ancestral de "no mirar hacia atrás», de "no volver la mirada». Tanto en la tradición semítica como en la griega el castigo divino pesa sobre la mirada retrospectiva.

1 Para un desarrollo algo más amplio ver Cabrera (2011). 
En el libro del Génesis, Lot recibe el permiso de salir para salvarse de la destrucción de Sodoma y Gomorra con la condición de no mirar atrás ni pararse. «Su mujer miró hacia atrás y se convirtió en estatua de sal» (Gn 19, 26). Ya antes, el mismo Génesis relata que tras la expulsión de Adán y Eva del paraíso, Dios se había asegurado de que no regresaran al Jardín del Edén y al árbol de la vida resguardándolo con querubines y una «llama de espada fulgurante» (cf. Gn 3, 24). La gran tentación de los seguidores de Moisés en el desierto era la nostalgia por la comida de Egipto: «¡Cómo nos acordamos del pescado que comíamos en balde en Egipto, y de los pepinos, melones, puerros, cebollas y ajos! En cambio ahora nos encontramos débiles. No hay nada. No vemos más que el maná» (Números 11, 5-6).

Yahvé lo reprocha a través del profeta: «se volvieron de espaldas, por no darme la cara» $(J r 7,24)$. En el caso del Jardín del Edén "no mirar atrás» significaba no regresar a la bienaventuranza del Paraíso. Algo similar sucedía en el desierto, Egipto era sinónimo de comida. En el caso de Sodoma y Gomorra, ¿habría algo «bueno» que recordar y extrańar? Independientemente de lo que fuera, lo que atraía no debía ser mirado.

La tradición cristiana consagra el mirar hacia delante. El evangelista lo expresa claramente: «le dijo Jesús: nadie que ponga la mano en el arado y mira hacia atrás es apto para el Reino de Dios» $(L c 9,62)$. Y Pablo lo tiene como consigna de vida cristiana: «una cosa hago: olvido lo que dejé atrás y me lanzo a lo que está por delante, corriendo hacia la meta» (Fil 3, 13-14).

Virgilio y Ovidio, desde otra tradición, narran el viaje de Orfeo al Hades en búsqueda de Eurídice, su amada (cf. Virgilio, Georg. IV 453527; Ovidio, Met. X 1-90; XI 1-66; ver también Séneca, Herc. furens 569591; Herc. Oetaeus 1031-1101). Orfeo salva todos los obstáculos y consigue el permiso de retornar con Eurídice pero con la condición de que ella lo siga y que él no vuelva la mirada hasta que hayan abandonado totalmente el inframundo. Según lo convenido, Eurídice seguía a Orfeo en el camino hacia la luz y en el momento en que estaban a punto de abandonar las oscuras profundidades, Orfeo no pudo soportar la tentación y se volvió para mirarla. Cuando esto ocurrió, Eurídice fue arrastrada hacia el Hades por una fuerza irresistible. Ella desaparece definitivamente y él queda en la versión de Ovidio como "petrificado anímicamente» (Albrecht 1995: 1733, cf. González Delgado, 2003: 7-35). 


\section{El imaginario andino: el pasado está delante}

El que mira, lo hace «hacia el frente». «Adelante» está lo que viene cuando uno camina y se mueve, por ello se dice que se "avanza». Casi todas las lenguas se hacen eco de esta concepción espacial del tiempo derivada de la corporalidad humana. De allí que casi todas las culturas e idiomas no solo caracterizan el tiempo con propiedades del espacio sino que atribuyen al futuro una posición espacial delante del hablante mientras ubican el pasado detrás.

El caso del pueblo Aymara ${ }^{2}$ se aparta de este modelo típico. Ellos tienen una particular concepción del tiempo expresada en el idioma y en la gestualidad. ${ }^{3}$ La palabra aymara que indica el pasado (nayra) significa literalmente ojo, a la vista o al frente. La palabra que traduce futuro (qhipa) quiere decir detrás o a la espalda. La palabra aymara (Qhipüru) que se traduce como mañana, combina qhipa (atrás) y uru (día), siendo literalmente 'día que está a la espalda'. La expresión nayra mara que significa 'año pasado', literalmente dice 'año adelante'.

En cuanto a los gestos que acompañan sus palabras los aymaras, especialmente los más ancianos (menos conocedores del español gramaticalmente correcto), cuando hablan de futuro indican un espacio detrás de ellos ya sea apuntando directamente con el dedo o por encima del hombro. Por el contrario, al hablar de pasado indican un espacio delante de sí mismos con sus manos y brazos más próximos al cuerpo para el presente o el pasado cercano, y con todo el brazo extendido para indicar épocas antiguas. Es decir, usan los mismos gestos a los que estamos acostumbrados pero exactamente al revés.

El idioma aymara concede gran importancia al hecho de que el hablante haya presenciado o no un acontecimiento o acción. Cuando habla-

2 «El aymara altiplánico, ó simplemente aymara, es un lengua andina hablada por un millón y seiscientos mil personas, en las proximidades del lago Titicaca. Más precisamente, según los últimos censos de Bolivia y Chile (1992) y del Perú (1993) existen 1237658 aymaristas bolivianos, 296465 aymaristas peruanos y 48477 aymaristas chilenos. También existen varias comunidades de las provincias argentinas de Salta y Jujuy que se autoproclaman aymaristas aunque no hablen esta lengua». Cf. http://aymara.org/. Ültima consulta en octubre de 2011.

3 En este comentario sigo a Núñez y Sweetser (2006). 
ban de períodos de varias generaciones el eje es «adelante-atrás» con ellos - los hablantes - en el punto central. Pero, si hablan de períodos de tiempo dilatados, sus gestos señalan de izquierda a derecha excluyéndose ellos mismos.

Entre los visitantes de los pueblos precolombinos es recurrente hablar de la experiencia en la diferencia de concepción del tiempo como, por ejemplo, el «ahorita» de ascendiente mexica o el «ahicito» de influencia quechua. La "gran paciencia» de los aymaras no juzga excesivo esperar medio día un transporte que les lleve al mercado. El visitante acostumbrado a la planificación, los horarios medidos cuantitativamente y las duraciones previstas sufre — rara vez disfruta — esta experiencia.

El resultado de tal concepción es que - como sostiene Martha Hardman, antropóloga de la Universidad de Florida— «si usted no puede ver el futuro, la planificación pierde parte de su importancia». ${ }^{4} Y$ con ello, pierde su sentido la idea de progreso (o su sucesora, desarrollo sustentable, sostenible, etc. Cf. Cabrera (2006: 91ss.), corazón del imaginario moderno.

De todas maneras habría que recordar que la importancia de la planificación se basa en la imagen de futuro, en las previsiones y en las expectativas. El futuro sólo existe como apuesta (capitalista, revolucionaria, social, personal, o la que fuera). El futuro es pura imagen. Por el contrario, el pasado fue real, existió. Por lo tanto, la imagen del pasado existe a partir de algo, es reconstrucción de algo que se supone existió con relativa independencia de los sujetos. Lo que el ser humano «tiene» es el presente y el pasado y, en ese sentido, es más «realista» mirar el pasado que sucedió y, por lo tanto, puedo conservarlo de alguna manera, que mirar hacia adelante donde no hay nada que ver.

\section{La modernidad y la negación del pasado}

Desde finales del siglo Xvin se concibe la historia como un proceso de perfeccionamiento continuo y creciente de la Humanidad. Esta con-

4 Citado en Spinney, Laura, «How time flies. For the Aymara people living in the Andes, the past lies ahead and the future lies behind. Laura Spinney looks at how different languages reflect, and shape, our conception of time», The Guardian, 24 de febrero de 2005. http://www.guardian.co.uk/science/2005/feb/24/4. 
cepción relaciona el «espacio de la experiencia», el presente de la acción, de una manera nueva con el «horizonte de expectativas» (cf. Koselleck 1993) creando una situación que justifica el sacrificio de unas generaciones por la felicidad de las que vendrán. El argumento asegura que la acumulación de la abundancia permitirá, con el tiempo, su redistribución. El mejor hecho que justifica este razonamiento son los grandes avances de la técnica que animan a la sociedad moderna para lanzarse hacia adelante.

La hybris moderna busca el adelante con particular obsesión. En el mismo acto en que la sociedad europea se autodefinió «moderna» tuvo que afirmar que venía de un pasado oscuro, de opresión y de ignorancia con el que debía romper y del que debía escapar. La luz de la razón descubría la oscuridad de su pasado inmediato y la imaginación alimentó el deseo de una sociedad nueva hacia la que había que huir. El Progreso, en tanto creencia incuestionable de la sociedad, convencía de la necesidad de mirar siempre hacia adelante, lo cual significaba también, no mirar atrás. La modernidad es, en este sentido, un viajero que corre motivado por las promesas de su creencia y sin tener en cuenta su atrás. Un atrás que es el pasado que opera como la narración de «lo sucedido» en una relación causal con lo que en el presente se considera «bueno» y "deseable». Un atrás formado retrospectivamente desde los valores, individuos y sociedad privilegiados por su condición de "triunfadores» o «exitosos». En esa versión causal, que desde el pasado «demuestra» la necesidad de que «las cosas fueran así», los oprimidos y las víctimas son "daños colaterales» (por seguir con el vocabulario de moda en las guerras del siglo XXI). Aunque se ha hecho bastante para contar sus historias, por ejemplo, el periodismo con todos sus errores y matices, no se narra la historia de los oprimidos y las víctimas porque «no conduce a nada».

La modernidad europea occidental tiene problemas con el atrás y el abajo; el retroceso y la lentitud (cf. Cabrera 2011) y con ello, problemas con los «retrasados», los «subdesarrollados» y en general con las víctimas del progreso que le recuerdan que la modernidad es producción sistémica de víctimas y marginación basada en el olvido. Dicho de otra manera, no hay modernidad — tal como se la define desde la idea de progreso (con sus sinónimos, matizaciones y metáforas)— sin injusticia (cf. Mate 2006). 


\section{Ante la mirada vs. mirar atrás}

«Tener el pasado frente a los ojos» $\mathrm{y}$ «mirar hacia atrás» tienen connotaciones muy diferentes. La primera expresión —en sus variaciones- sugiere recordar, tener presente lo sucedido. La segunda connota añoranza, es decir, un detenerse a recordar con pena una ausencia o una pérdida.

El tener el pasado ante la mirada sugiere la presencia de una imagen para no repetir los errores que ya se han cometido. Sería el requisito para protegernos a nosotros mismos de los errores de otros en el pasado y sus posibles efectos negativos y, en ese mismo sentido, puede servir también para recordar las salidas y soluciones ya experimentadas. El decir popular afirma que «el hombre es el único animal que mete la pata dos veces en el mismo agujero". ¿Por qué? Porque el pasado para el animal es a la manera de "tener el pasado ante la mirada", adiestramiento del individuo y memoria genética de la especie. El ser humano olvida y recuerda selectivamente.

La expresión mirar hacia atrás entraña detenerse, girarse y sentir la pérdida. No busca protegerse de los errores de los otros, sino simpatizar con las personas, sus acciones y su destino. El que mira atrás no solo busca «aprender» mirando los errores y aciertos de otros sino también, recordar al otro aún a costa de la eficacia de la propia acción.

El ser humano, al contrario que el resto de animales, puede reconsiderar lo pasado. Tiene la libertad de reinterpretarlo y recrearlo. Mirar atrás puede ser, incluso, una manera de ensayar nuevas posibilidades de acción, de adaptación y de supervivencia. En los animales el pasado se vuelve instinto, en el ser humano un territorio siempre por explorar.

Estas frases — tener el pasado ante la mirada y mirar hacia atrás - connotan dos modos muy diferentes de la memoria. La primera se refiere al recuerdo como traer a la conciencia hechos y personas del pasado para «aprender», esquivar los errores y repetir los aciertos. Los historiadores preparan ese saber. En el segundo sentido la memoria se comunica con el pasado para rememorar, celebrar y revivir, los antepasados.

El pensar es re-flexión, una "vuelta atrás de la mirada», para mirar de frente y percibir el reflejo, es decir, la devolución de la vista. Pensar, en este sentido, constituye percibir cómo nos mira lo que vemos. Porque somos mirados podemos ver, porque somos pensados podemos pensar. El pensar 
comienza cuando se siente la mirada y nos damos vuelta para ver lo que nos mira. El pensar no nace de un acto de iluminación del ser humano sino de su respuesta al advenimiento inquietante de la mirada de un algo o alguien que está allí. Un algo o alguien cuya presencia incomoda y reclama re-conocimiento, re-cuerdo, re-flexión. El mirar atrás se manifiesta así como sinónimo de un despertar e, incluso, de un renacer.

\title{
6. Mnemósine y Leteo: las aguas de la memoria y del olvido
}

\author{
Soñé que el río me hablaba \\ con voz de nieve cumbrera \\ y dulce me recordaba \\ las cosas de mi querencia. \\ Tú que puedes, vuélvete, \\ me dijo el río llorando; \\ los cerros que tanto quieres, \\ me dijo, allá te están esperando. \\ Atahualpa Yupanqui
}

En el sueño, narra el cantor tradicional argentino, el río le hablaba y con ello le recordaba su querencia. Le decía «tú que puedes, vuélvete» porque la montaña, fuente del río y casa del soñador, «allá te están esperando». Según la liturgia cristiana, el sueño es hermano de la muerte y para los griegos la muerte implicaba un «bajar» a los infiernos (Hades o Averno).

Normalmente la entrada al mundo de los muertos se relacionaba con algunas oquedades geológicas bien conocidas. En el interior se imaginaba un medio acuático por el que el muerto debía navegar para llegar «al otro lado». En ese contexto los grupos gnósticos mistéricos redefinieron el papel del agua para ese tránsito.

La iniciación a los misterios era una condición necesaria para no perderse en el inframundo porque en su recorrido final el viajero experimentaba una gran sed que ansiaban satisfacer. Los no iniciados, los que no tenían el conocimiento necesario, bebían del río Leteo el agua del olvido. Bebiéndola el alma se embrutecía y se lanzaba a una nueva vida en la tierra sometida a la ignorancia y condenada a la repetición. En cambio el viajero iniciado en los misterios bebía de Mnemósine el agua de la memoria y se abría paso a una bienaventuranza post-mortem reservada a los sabios. 
El mirar atrás lleva a considerar el tema de la memoria y el olvido haciendo surgir el problema del perdón (cf. Arendt 1996; Ricoeur 2003). Es probable que, como aconsejaban algunos gnósticos, las aguas de Mnemósine y las de Leteo deban ser bebidas alternativamente para poder poner lo pasado ante la mirada y evitar la ancestral condena de petrificación.

La navegación aprecia el viento en popa, también los velocistas, sin embargo, la aviación teme al viento de cola. Lo que viene de atrás puede ayudar o perjudicar el avance dependiendo del transporte. La modernidad occidental euro-americana ha nacido bajo el signo del poniente y el ocaso, teme lo que viene de abajo y de atrás porque su transporte - la tecnología - solo puede avanzar con la promesa incuestionable del progreso y el desarrollo. Mirar hacia atrás puede resultarle literalmente desastroso, por eso la modernidad prefiere beber de Leteo y mirar hacia adelante.

\section{Referencias}

Albrecht, M. von (1995): "Orfeo en Virgilio y Ovidio», Myrtia, 10: 17-33.

Arendt, H. (1996): La condición humana, Barcelona, Paidós.

Bauman, Z. (2005): Vidas desperdiciadas. La modernidad y sus parias, Buenos Aires, Paidós.

Benjamin, W. (2005): Libro de los Pasajes, Madrid, Akal.

CABrera, D. H. (2006): Lo tecnológico y lo imaginario. Las nuevas tecnologías como creencias y esperanzas colectivas, Buenos Aires, Biblos.

- (2011): Comunicación y cultura como ensoñación social, Madrid, Fragua.

Díez de Velasco, F. (2004): «Imaginando el más allá en el mundo griego», en

M. L. Sánchez León, El más allá, Universidad de La Laguna, Palma de Ma-

llorca. Disponible en http://webpages.ull.es/users/fradive/artic/masallapalma. pdf Consultado en octubre de 2011.

DodDs, E. R. (1999): Los griegos y lo irracional, Madrid, Alianza.

González Delgado, R. (2003): «Interpretaciones alegóricas del mito de Orfeo y Eurídice por Fulgencio y Boecio y su pervivencia en la Patrología Latina», Faventia 25/2, 2003: 7-35.

Hillman, J. (1994): «El sueño y el inframundo», en K. Kerényi, E. Neumann, G. Scholem y J. Hillman: Arquetipos y simbolos colectivos. Círculo Eranos I, Barcelona, Anthropos.

Koselleck, R. (1993): Futuro Pasado. Para una semántica de los tiempos históricos, Barcelona, Paidós. 
Mate, R. (2006): Medianoche en la Historia. Comentario a las tesis de Walter Benjamin, "Sobre el concepto de Historia», Madrid, Trotta.

- (2008): La herencia del olvido. Ensayos en torno a la razón compasiva, Madrid, Errata Naturae.

Minors, G. (2004): Historia del infierno. De la Antigüedad hasta nuestro dias, México, Taurus.

Núñez, R. E. y E. Sweester (2006): «With the Future Behind Them: Convergent Evidence From Aymara Language and Gesture in the Crosslinguistic Comparison of Spatial Construals of Time», Cognitive Science, 30: 1-49. Disponible en http://www.cogsci.ucsd.edu/ nunez/web/NSaymaraproofs.pdf. Última consulta en octubre de 2011.

Ricoeur, P. (2003): La memoria, la historia, el olvido, Madrid, Trotta. 


\section{UNA VISIÓN FOUCAULTIANA SOBRE LA HISTORIA RECIENTE DE LA LINGÜÍSTICA}

Ángel López García (Universidad de Valencia)

Como es sabido, la obra de Karl Popper sentó las bases de la moderna epistemología de la ciencia, aunque el racionalismo ingenuo que postulaba, basado en el rechazo de toda hipótesis que hubiese sido falsada antes, fue prontamente enmendado por dos autores que siguen siendo el marco de referencia todavía hoy: Kuhn y Lakatos. La aportación de Kuhn consistió básicamente en sociologizar la ciencia, esto es, en destacar el hecho de que las circunstancias externas influyen enormemente en la tarea del científico, siendo responsables de las creencias en las que se forma. Dichas ideas modelan el conjunto de problemas de los que se ocupa y a los que debe dar respuesta. Es lo que llamó paradigma: cada periodo estaría caracterizado por un paradigma y la revolución consistiría en la sustitución de dicho paradigma por otro. La aportación de Lakatos, llamada programas de investigación cientifica, es menos radical en cuanto a la unicidad del paradigma: los programas son paradigmas coexistentes que presentan un núcleo duro y un cinturón auxiliar de hipótesis, que son las que se someten a contrastación empírica. Además, no solo no puede decirse que haya una sucesión de modelos que van desplazando a los anteriores, sino que, junto a los programas progresivos, existen otros que son regresivos. Podríamos resumir estos tres planteamientos como sigue: 


\begin{tabular}{|l|l|l|}
\hline \multicolumn{1}{|c|}{ A: Karl Popper } & \multicolumn{1}{|c|}{ B: Alwin Kuhn } & \multicolumn{1}{c|}{ C: Imre Lakatos } \\
\hline $\begin{array}{l}\text { Las teorias pueden ser } \\
\text { falsadas y, al hacerlo, la } \\
\text { ciencia las abandona y } \\
\text { pasa a otras. }\end{array}$ & $\begin{array}{l}\text { Los paradigmas se } \\
\text { suceden inclusivamente, } \\
\text { los nuevos incluyen a } \\
\text { los antiguos. }\end{array}$ & $\begin{array}{l}\text { Los programas coexisten } \\
\text { con otros programas y } \\
\text { pueden mejorar o } \\
\text { empeorar. }\end{array}$ \\
\hline
\end{tabular}

La representación gráfica de las perspectivas A, B y C sería:

A:

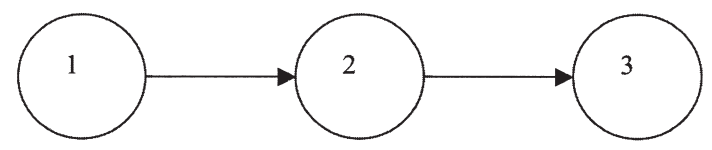

B:

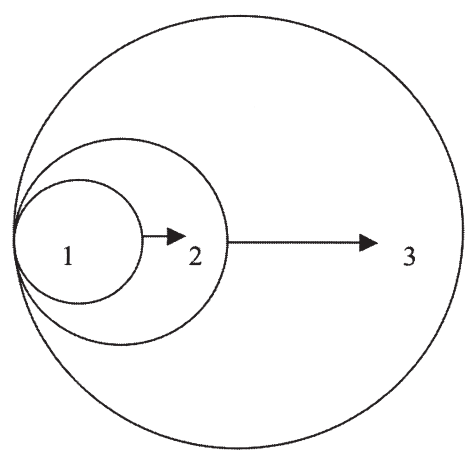

C:

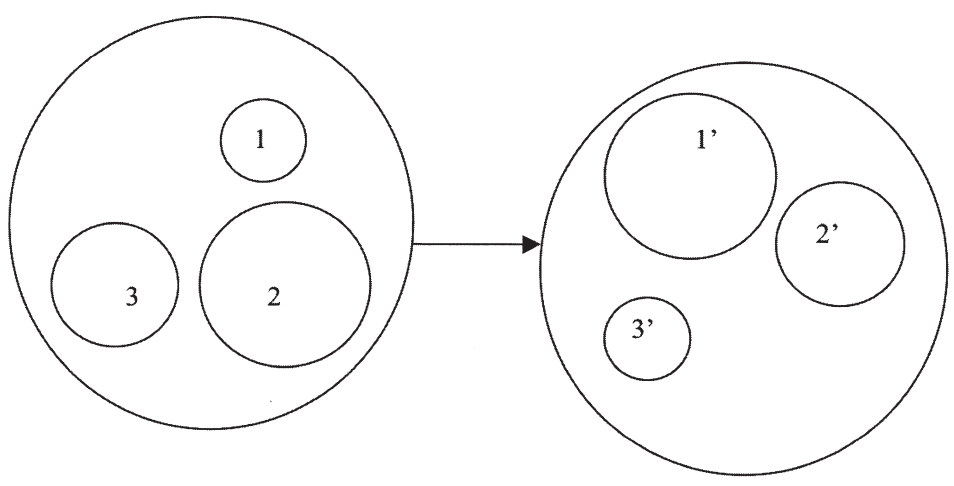


Si ahora acudimos a la forma que suelen adoptar los manuales de historia de la lingüística, advertiremos que los tres modelos que se reparten modernamente las preferencias de los lingüistas, el estructuralista, el generativista y el cognitivista, se presentan al lector siguiendo alguna de las disposiciones de la figura de arriba:

A) Para muchos historiadores de la lingüística, el estructuralismo, como modelo dominante en la década de los cincuenta y sesenta del siglo pasado, habría sido reemplazado por el generativismo, que tuvo su apogeo en los setenta y en los ochenta, hasta que este fue sustituido a su vez por el cognitivismo en los noventa y en la primera década del presente siglo. No hay que decir que en cuanto a los datos externos esto es exactamente así: el grueso de los autores, de los departamentos y de las publicaciones, fueron estructuralistas, más tarde generativistas y hoy son cognitivistas. Con independencia de la postura personal de cada cual, esta sucesión de modelos responde a la vez al cambio de las modas y a la erosión de propuestas que fueron irremediablemente falsadas. Sin embargo, más interesante es el hecho de que ciertos manuales presenten la historia de la disciplina exactamente conforme al patrón A. Así lo hace, por ejemplo, Cerny (1996), quien tras exponer las escuelas estructuralistas de Ginebra, Praga, Copenhague y EE.UU., pasa a ocuparse de la gramática generativa y finalmente, desconocedor al parecer de la aportación de Langacker, Lakoff o de la teoría de prototipos, trata del paradigma cognitivo que representa la gramática estratificacional.

B) El modelo inclusivo (Koerner 2004) concibe la gramática generativa como una superación del estructuralismo, cuyas contradicciones resolvería, al tiempo que trata el cognitivismo como una consecuencia de los interrogantes abiertos por la gramática generativa y que fueron resueltos por autores como Lakoff o McCawley que, en definitiva, son generativistas heterodoxos. Es el punto de vista expuesto por Searle (1972) en su célebre artículo sobre la presunta revolución chomskiana.

C) El planteamiento más actual consiste en atribuir a cada escuela la focalización del interés en cierto nivel o tipo de fenómenos y tratarlos todos como un conjunto (Lakoff 1989: 985-986):

We have tried for most of this century to force language into the Procrustean bed of 'science', and the chaos and dissension that we have experienced in the field are the result. If we are a science, we must assume that 
only one paradigm has access to the truth, and it had better be our own. But the impossibility of getting everyone in the field to accept a single paradigm, to settle down to Kuhnian 'normal science', demonstrates that we have been seeing things incorrectly. [...] each linguist, or each theoretical perspective, captures a different vision of the linguistic reality, and all, though incompatible as scientific theories, have something to add to our knowledge. But we can no longer require that perspectives be combinable into one single theory: We must settle for different, but equally valid,

rechazando decididamente el sectarismo de la etapa anterior (Lakoff 1989: 956, nota 5):

To abjure non-discrete theories because they are unsettling, or because they conflict with the kinds of formalism we currently feel comfortable with, is antiscientific in the most dangerous way: analogous to the Church's determination that Galileo's claims were heretical because they were antithetical to current established wisdom.

Y es que, como nota Kertész (2010: 31-32), el pluralismo de la lingüística actual responde a un planteamiento gnoseológico cercano a los programas de investigación de Lakatos:

New insights: research topics, methods, data. It is at least partly due to this pluralism that the research we have overviewed and analyzed enriched the historiography of linguistics with new topics, new data, and new methods. A rich inventory of topics has emerged, has triggered interesting debates and has shaped historiographic thought in linguistics —as outlined in the previous section-. A great variety of methods have been applied including, among others, 'conservative' historiographic research, postmodernism, sociological research, the Lakatosian framework, etc. New data were detected and interpreted from many different points of view.

Curiosamente, en todo lo que llevamos dicho hasta ahora, la lingüística nunca se discute, se da por supuesto que está ahí y que los académicos que se ocupan de ella han estado más o menos acertados en la forma de tratarla. Pero también podría adoptarse otro tipo de perspectiva, mucho más radical: ¿đe veras existe la lingüística?; ¿no será una invención (en el sentido de inventio) humana, propia de un determinado momento histórico e imputable a circunstancias que podrían no haberse dado o acabar desapareciendo? Este planteamiento es típico de Foucault. No en relación con la lingüística, pero sí sobre otros muchos temas, entre ellos el lenguaje (Foucault 1966). La base de partida de su pensamiento es el rechazo de las ideas generales, las cuales tienen siempre un valor de época legitimado por un determinado discurso: los contemporáneos están encerrados en discur- 
sos como en peceras falsamente transparentes, que no solo desconocen, sino que incluso podrían no existir. El discurso sobre el lenguaje, resulta inseparable de los siglos XIX y xx porque (Foucault 1966: IX-1):

Que la littérature de nos jours soit fascinée par l'être du langage, ce n'est là ni le signe d'une fin ni la preuve d'une radicalisation: c'est un phénomène qui enracine sa nécessité dans une très vaste configuration où se dessine toute la nervure de notre pensée et de notre savoir. Mais si la question des langages formels fait valoir la possibilité ou l'impossibilité de structurer les contenus positifs, une littérature vouée au langage fait valoir, en leur vivacité empirique, les formes fondamentales de la finitude. De l'intérieur du langage éprouvé et parcouru comme langage, dans le jeu de ses possibilités tendues à leur point extrême, ce qui s'annonce, c'est que l'homme est "fini», et qu'en parvenant au sommet de toute parole possible, ce n'est pas au coeur de lui-même qu'il arrive, mais au bord de ce qui le limite: dans cette région où rôde la mort, où la pensée s'éteint, où la promesse de l'origine indéfiniment recule... En fait, il s'agit là du dépli rigoureux de la culture occidentale selon la nécessité qu'elle s'est donnée à elle-même au début du XIX ${ }^{\circ}$ siècle. Il serait faux de voir, en cet indice général de notre expérience qu'on peut appeler le «formalisme», le signe d'un dessèchement, d'une raréfaction de la pensée incapable de ressaisir la plénitude des contenus; il ne serait pas moins faux de la placer d'emblée sur l'horizon d'une nouvelle pensée et d'un nouveau savoir. C'est à l'intérieur du dessin très serré, très cohérent de l'epistémè moderne que cette expérience contemporaine a trouvé sa possibilité; c'est même lui qui, par sa logique, l'a suscitée, l'a constituée de part en part, et a rendu impossible qu'elle n'existe pas. Ce qui s'est passé à l'époque de Ricardo, de Cuvier, et de Bopp, cette forme de savoir qui s'est instaurée avec l'économie, la biologie et la philologie, la pensée de la finitude que la critique kantienne a prescrite comme tâche à la philosophie, tout ceci forme encore l'espace immédiat de notre réflexion. Nous pensons en ce lieu.

O sea que el interés por el lenguaje es propio de la época moderna en la medida en la que se han acabado todos los trascendentalismos. La muerte de Dios, que diría Nietzsche, es a la vez el triunfo de la forma y, con ella, el de la apariencia. El lenguaje no transporta la verdad, como pensaban los racionalistas de Port Royal y los positivistas lógicos, la enmascara dotándola de múltiples visajes. Lo curioso es que este tipo de planteamiento, que debería haber hecho desconfiar a Foucault de la lingüística, no le lleva consecuentemente a mirarla con recelo. Así en su célebre conferencia de 1994, impartida en el CERS de la Universidad de Túnez, se ocupa de la lingüística por primera y única vez en estos términos (Foucault 1994: 821-822):

On trouve fréquemment exprimée la thèse suivante [...]: l'analyse du langage par Saussure et ses successeurs, c'est-à-dire la linguistique structurale, vient d'atteindre, au cours $\mathrm{du} \mathrm{Xx}^{\mathrm{e}}$ siècle, ce qu'on pourrait appeler un seuil de 
scientificité. Ce seuil de scientificité est rendu manifeste, d'un côté, par les techniques de formalisation dont maintenant la linguistique est susceptible, d'un autre côté, par le rapport quélle entretient avec la théorie des communications, avec la théorie de l'information en général, troisièmement, par ses liens récents avec la biologie, la biochimie, la génétique, etc., et, en fin, par l'existence d'un domaine technique d'application dont les machines à traduire ne sont, après tout, qu'un des exemples. La linguistique aurait donc franchi un certain seuil, émergé des sciences humaines vers les sciences de la nature, du domaine de la connaissance interprétative à celui de la connaissance formelle... Deuxième thèse que l'on rencontre fréquemment: à partir du moment où la linguistique aurait quitté sa vieille appartenance et son familiarité avec les sciences humaines, elle se serait trouvée par rapport à ces sciences humaines dans une position de modèle à suivre... Ainsi se serait instaurée une sorte de course-poursuite, la linguistique passant du côté des sciences exactes et toutes les sciences humaines essayant de rejoindre avec la linguistique le niveau normatif des sciences exactes.

La anterior es una descripción bastante exacta del ambiente en el que nos hemos formado todos los que cursamos estudios universitarios en la década de los setenta del siglo pasado. O deformado, si se quiere. Lo cierto es que Foucault objeta a este planteamiento, pero objeta poco. Por un lado, afirma que la idea de que el pensamiento de una época se expresa en moldes lingüísticos ya estaba en autores del siglo XviII como D’Alembert (y también en nuestro Diccionario de Autoridades académico, según ha mostrado Val, 1993, añadiría yo). Por otro lado, matiza que lo importante no es la condición de la lingüística como ancilla hominis scientiarum, sino (Foucault 1994: 823-824):

Le fait nouveau serait plutôt que la linguistique vient de donner aux sciences sociales des possibilités épistémologiques différentes de celles que’elle leur offrait jusque-là... On pensait que l'on avait rationalisé un domaine empirique lorsqu'on avait pu établir une relation de causalité entre un phénomène et un autre. Et voilà que maintenant, grâce à la linguistique, on découvre que la rationalisation d'un champ empirique ne consiste pas seulement à découvrir et à pouvoir assigner cette relation précise de causalité, mais à mettre au jour tout un champ de relations qui sont probablement du type des relations logiques.

¿Qué clase de lógica es la que permite descubrir la lingüística? Según Foucault (1994: 825-826) la que Marx llamaba el análisis lógico de lo real, el cual tiene por fundamento la comunicación:

Du coup, l'analyse du langage, au lieu d'être rapportée à une théorie de la représentation ou à une analyse psychologique de la mentalité des sujets, se trouve maintenant mise de plain-pied avec toutes les autres analyses qui 
peuvent étudier les émetteurs et les récepteurs, le codage et le décodage, la structure des codes et le déroulement du message... Le collectif dans cette nouvelle perspective ne sera plus l'universalité de la pensée... Le collectif, maintenant, c'est un ensemble constitué par des pôles de communication, par des codes qui sont effectivement utilisés et par la fréquence et la structure des messages qui sont envoyés.

Los foucaultianos se debieron sentir decepcionados con esta conferencia de Foucault. No porque no fuera estrictamente actual y aun premonitoria: pronunciada en 1969, a fines del siglo xx la lingüística ya se había vuelto, como sabemos, análisis del discurso. Incluso puede que le perdonasen su contestación (Foucault 1994: 838) a uno de los autores que participaron en el debate, cuando niega ser estructuralista y se proclama - pasmosamente - partidario de la gramática generativa o transformacional que dice ser el método que ha intentado introducir en la historia de las ideas. Es evidente que a esas alturas Foucault empezaba a chochear, pues nada hay más alejado del estudio de los mensajes y de quienes participan en ellos que dicho modelo formalista. No, lo verdaderamente sorprendente es el trato de favor que dispensa a la lingüística en comparación con las demás ciencias.

La base del pensamiento de Foucault es la relación que establece entre el conocimiento y el poder, para él no existen ciencias absolutas, sino que se han ido formando en el seno de una determinada sociedad en función del juego de tensiones sociales que la constituye (Foucault 1969). Esto se aprecia claramente en su emblemático libro sobre la locura (Foucault 1972). En él muestra que el concepto de locura ha ido cambiando a través del tiempo y ha venido determinado en cada caso por la percepción y la práctica sociales. En la Edad Media la locura era sagrada y los locos circulaban libremente. En el Renacimiento su carácter sagrado se transformó en sabiduría: el bufón sabio (Don Quijote) expresaba, en su desvarío, el de la sociedad a la que pertenecía. Durante el clasicismo del Siglo de las Luces, el siglo de la razón cartesiana, la locura fue tildada de no-razón y los locos pasaron a ser encerrados junto con los mendigos y los criminales. Tras la Revolución francesa, la evaluación de la locura cambió una vez más: se le dio un tratamiento médico a base de fármacos y corrientes y pasó a ser considerada una enfermedad de la mente. Todavía, el paso al siglo xx conocerá una nueva etapa, la psiquiatría freudiana, en la que el loco se convierte en personaje público que se confiesa, pero queda sometido a la auto- 
ridad «burguesa» del psicoanalista. Sería interesante saber lo que habría dicho de estos nuevos locos del siglo XXI — Foucault fallece en 1984_, los "terroristas», que pueden ser indistintamente fundamentalistas religiosos, fanáticos nacionalistas o cualquier otra cosa.

Llama la atención que quien tan lúcidamente analizó la evaluación de la locura y de muchos otros fenómenos, se haya mostrado tan dócilmente tópico al tratar la lingüística. Y es que, de acuerdo con sus planteamientos, la lingüística no debería existir, más bien existirían diferentes lingüísticas esencialmente contingentes y que se suceden por razones que tienen que ver con los cambios sociales antes que con los modelos evolutivos de la ciencia que examinábamos arriba.

¿Cuáles son estos cambios sociales? Después de la Primera Guerra Mundial, con la que propiamente acaba el viejo orden simbolizado por el hundimiento del Imperio austro-húngaro, ha habido en Occidente tres tipos básicos de configuración política y social: el periodo de entreguerras, caracterizado por fuertes tensiones económicas - el crack de Wall Street en 1929, la hiperinflación de la república de Weimar-y el estallido de los nacionalismos dominantes - el fascismo en Italia, el nazismo en Alemania- , todo lo cual culmina en la gran tragedia de la Segunda Guerra Mundial; la guerra fría, que fue la consecuencia del reparto del mundo operado en dicho conflicto bélico; la caída del muro, con la aparición de un mundo global en el que nuevos estados emergentes toman la alternativa e instauran una hegemonía compartida. Sugiero que cada uno de estos periodos, reconocidos unánimemente por los historiadores, se corresponde con uno de los tres modelos lingüísticos que se han sucedido desde entonces:

\begin{tabular}{|c|c|c|}
\hline $\begin{array}{c}\text { Belle époque y guerra } \\
(1919-1944)\end{array}$ & $\begin{array}{c}\text { Guerra fria } \\
(1945-1988)\end{array}$ & $\begin{array}{c}\text { Globalización } \\
(1989-\ldots)\end{array}$ \\
\hline esctructuralismo & generativismo & cognitivismo \\
\hline
\end{tabular}

El movimiento estructuralista puede ser caracterizado en Europa por la escuela de Praga, la cual había sido precedida por el círculo de Moscú y por el de Ginebra. Las obras fundacionales son todas de este periodo. El Cours de linguistique générale de Ferdinand de Saussure (1916), aparecido prematuramente a iniciativa de los discípulos del maestro fallecido, repre- 
senta una transición entre el mundo antiguo de la lingüística indoeuropea y el mundo naciente de la nueva lingüística. Plenamente estructuralista se revela, en cambio, el llamado periodo clásico del círculo de Praga, fundado en 1926 y que termina con la segunda guerra en 1939, el cual podríamos simbolizar con la Sprachtheorie (1934) de Karl Bühler, con los Grundzüge der Phonologie (1939) de Nikolai Trubetzkoy o con el artículo «Zur Struktur des russischen Verbums» (1932) de Roman Jakobson. Fuera de esta corriente principal, surgieron escuelas estructuralistas de menor alcance, como la psicomecánica, que se formula teóricamente en Temps et verbe (1929) de Gustave Guillaume, o como la escuela de Copenhague, algo más tardía, cuyo texto fundacional fue Omkring sprøgteoriens grundlaeggelse (1943) de Luis Hjelmslev. En cuanto al estructuralismo americano, alcanza su madurez propiamente con Language (1923) de Edward Sapir y con la obra homónima Language (1933) de Leonard Bloomfield, alargándose en la década de los treinta y de los cuarenta mediante una serie de trabajos de Rulon S. Wells, W. Freeman Twaddell, Morris Swadesh, Charles F. Hockett o Zellig Harris que se recogen en la compilación Readings in Linguistics publicada en 1957 por Martin Joos.

No me interesa caracterizar metodológicamente el estructuralismo ni el sesgo que cada uno de estos autores representa con respecto al tronco común. Lo que importa es destacar la visión que todos ellos comparten con respecto al lenguaje como instancia gnoseológica fundamental, ya desde Saussure. Dicha visión considera que el valor de cada elemento lingüístico es una resultante del conjunto de las interacciones hablante-oyente y que el sistema que estas perfilan caracteriza como tal a la sociedad que se sirve del mismo, según refleja de la llamada hipótesis del relativismo lingüístico, que podríamos caracterizar con las siguientes palabras de Benjamin Lee Whorf (1956: 251-252, 1. ${ }^{a}$ ed., 1942).

Thus he implies, wrongly, that thinking is an obvious, straightforward activity, the same for all rational beings, of which language is the straightforward expression. Actually, thinking is most mysterious, and by far the greatest light upon it that we have is thrown by the study of language. This study shows that the forms of a person's thoughts are controlled by inexorable laws of pattern of which he is unconscious. These patterns are the unperceived intricate systematizations of his own language, shown readily enough by a candid comparison and contrast with other languages, especially those of a different linguistic family. His thinking itself is in a language - in English, in Sanskrit, in Chinese- . And every language is a vast pattern-system, different from others, in which are culturally ordained the forms and categories by which the 
personality not only communicates, but also analyzes nature, notices or neglects types of relationship and phenomena, channels his reasoning, and builds the house of his consciousness.

No es de extrañar. La época de entreguerras fue una época caracterizada por las pulsiones nacionalistas que había abierto la disgregación del imperio austro-húngaro resultante de la primera guerra mundial. Se suele decir que el nacionalismo lingüístico es una ideología típicamente romántica. Pero esto es inexacto. En el siglo XIX, también como consecuencia de otro hundimiento, el del antiguo régimen, comienza el nacionalismo, pero la importancia de las lenguas para apuntalar las nacientes naciones fue más bien testimonial. Como advierte Zabaltza (2006: cap. 3), en el siglo xIx los límites de la nación se confían al territorio antes que al idioma. La uniformización de todas estas "naciones» emergentes con criterios lingüísticos es muy posterior, se produce en el periodo de entreguerras que estamos considerando.

Enteramente diferente fue la visión del mundo que desplazó a la que acabamos de examinar. La guerra fría consistió en que la totalidad de lo pensable se encara desde una de las dos ideologías antagónicas, la capitalista neoliberal o la marxista-leninista, que rigen respectivamente la vida de los ciudadanos en Occidente o en los países socialistas (Hunt 1987). Los dos sistemas se consideraban mutuamente incompatibles y determinaron sendas cazas de brujas - la del senador McCarthy en EE. UU. y las purgas de Stalin en la URSS, aunque no sean comparables por sus efectos sobre las víctimas - contra los enemigos de los principios monolíticos que regían cada bloque. Resulta difícil dar cuenta del increíble sectarismo que, de una y otra parte, caracterizó a esta época. Cada lado del llamado telón de acero estaba convencido de poseer toda la verdad y que los otros no decían sino falsedades.

Era inevitable que este extremado maniqueísmo epistemológico tuviera su correlato en la lingüística de la época. Las siguientes palabras de Chomsky (1965: 4-5) constituyen toda una declaración de principios:

A fully adequate grammar must assign to each of an infinite range of sentences a structural description indicating how this sentence is understood by the ideal speaker-hearer. This is the traditional problem of descriptive linguistics, and traditional grammars give a wealth of information concerning structural descriptions of sentences. However, valuable as they obviously are, traditional grammars are deficient in that they leave unexpressed many of the 
basic regularities of the language with which they are concerned... An analysis of the best existing grammars will quickly reveal that this is a defect of principle, not just a matter of empirical detail or logical preciseness.

Este radicalismo, que conduce a rechazar todas las demás corrientes lingüísticas, convertidas en adversarios a los que nunca se cita y a los que jamás se reconoce ningún acierto, no se atenuó con el paso del tiempo. Al contrario, treinta años más tarde (Chomsky 1995: 1-2) el rechazo se hace extensivo a otras ciencias que pudieran sostener un punto de vista diferente:

Any progress toward this goal will deepen a problem for the biological sciences that is already far from trivial: how can a system such as human language arise in the mind/brain, or for that matter, in the organic world, in which one seems not to find anything like the basic properties of human language? That problem has sometimes been posed as a crisis for the cognitive sciences. The concerns are appropriate, but their locus is misplaced; they are primarily a problem for biology and the brain sciences, which, as currently understood, do not provide any basis for what appear to be fairly well established conclusions about language.

En medio queda una vertiginosa sucesión de modelos teóricos que se van desechando cada poco tiempo, una sorprendente limitación a los ejemplos tomados del inglés y una tendencia creciente de los discípulos a aplicar las propuestas chomskianas a sus lenguas maternas, pero sin contradecirlas jamás. También, la propensión a controlar los departamentos de Lingüística de EE.UU. y de otras partes del mundo con técnicas implacables de exclusión de todos los que osan disentir del credo (Bernárdez 2008). Es notable que Chomsky haya desarrollado una trayectoria paralela de activista antiimperialista y que se le pueda considerar un marxista. Pero este posicionamiento ideológico no cambia lo esencial de nuestro argumento, pues su valentía no deja de estar teñida del radicalismo típico del periodo.

La ideología de la guerra fría ha sido desplazada por la ideología de la aldea global. Según Marshall MacLuhan «the new electronic interdependence reveals the world in the image of a global village» (McLuhan 1962: 31 ), de manera que "today, after more than a century of electric technology, we have extended our central nervous system in a global embrace, abolishing space and time as far as our planet is concerned» (McLuhan 1964: 3). Dicho soporte ha permitido desarrollar una economía fluida que escapa al control de los estados nacionales y amenaza con llevar al mundo a la catástrofe (Herman 1999). La nueva lingüística cognitiva comparte 
esta ubicuidad de manifestación. Ya no hay niveles, como destaca Langaker (1987) siguiendo de cerca a los neurobiólogos (Damasio 1995), el lenguaje no existe como módulo independiente, sino que es una parte integral de la cognición-emoción humana; las relaciones lingüísticas no se presentan casi nunca como una cuestión de todo o nada porque los rasgos que definen las unidades semánticas o fonológicas se mezclan, generando compuestos que no equivalen a la simple suma de las partes. La polisemia y la metaforización se han adueńado de nuestras representaciones simbólicas. De ahí resulta un constante proceso de reestructuraciones gestálticas y una inestabilidad permanente que, si bien se ajusta mejor que ningún otro modelo a la naturaleza del lenguaje, resulta inquietante cuando de lo que se trata es de regular la economía y con ella la vida de las personas. Pero esta ya es otra historia, la de nuestro hic et nunc.

\section{Referencias}

Bernárdez, E. (2008): El lenguaje como cultura, Madrid, Alianza.

Cerny, J. (1996): Dejiny lingvistiky, Olomouc, Votobia [ed. española: Historia de la Lingüistica, Cáceres, Universidad de Extremadura, 1998].

Сномsкy, N. (1965): Aspects of the theory of syntax, Cambridge, The MIT Press.

- (1995): The Minimalist Program, Cambridge, The MIT Press.

Damasio, A. (1995): Descartes' error. Emotion, Reason, and the Human Brain, Nueva York, Harper Perennial.

Foucault, M. (1966): Les mots et les choses, París, Gallimard.

- (1969): L'archéologie du savoir, París, Gallimard.

- (1972): Histoire de la folie à l'áge classique, París, Gallimard.

- (1994): «Linguistique et sciences sociales», en D. Defert y F. Ewald (eds.), Dits et écrits 1954-1988, vol. I, París, Gallimard, 821-842.

Herman E. S. (1999): «The Threat of Globalization», New Politics, 7-2.

Hunt, M. H (1987): Ideology and American Foreign Policy, New Haven, Yale University.

Kertész, A. (2010): «From 'scientific revolution' to 'unscientific revolution': an analysis of approaches to the history of generative linguistics», Language Sciences, 32: 507-527.

Koerner, E. F. K. (2004): «Linguistics and Revolution. With Particular Reference to the 'Chomskyan Revolution'», Antwerp Papers in Linguistics, 106: 3-62.

Kunn, T. S. (1970): The Structure of Scientific Revolutions, Chicago, The University of Chicago Press. 
Lakatos, I. (1970): "Falsification and the Methodology of Scientific Research Programmes», en I. Lakatos y A. Musgrave (eds.), Criticism and the Growth of Knowledge, Cambridge, Cambridge University Press: 91-195.

Lakoff, R. (1989): «The Way We Were; or: The Real Truth About Generative Semantics: A Memoir», Journal of Pragmatics, 13: 939-88.

Langaker, R. W. (1987): Foundations of Cognitive Grammar. Volume I: Theoretical Prerequisites, Stanford, Stanford University Press.

McLuhan, M. (1962): The Gutenberg Galaxy, Londres, Routledge \& Kegan Paul.

- (1964), Understanding Media. The Extensions of Man, Nueva York, Mentor.

Searle, J. (1972): "Chomsky's Revolution in Linguistics", The New York Review of Books, junio 29.

Trier, J. (1931): Der deutsche Wortschatz im Sinnbezirk des Verstandes, Heidelberg, Winter.

Val Álvaro, J. F. (1993): Ideas gramaticales en el Diccionario de Autoridades, Madrid, Arco.

Whorf, B. L. (1956): Language, Thought and Reality. Selected Writings of B.L.W., ed. John B. Carroll, Cambridge, The MIT Press.

Zabaltza, X. (2006): Una historia de las lenguas y los nacionalismos, Barcelona, Gedisa. 



\section{¿SI COSERIU VIVIERA, SERÍA COGNITIVISTA»? EXPLORACIONES SOBRE LOS ANTECEDENTES LINGÜÍSTICOS HISTÓRICOS DE LAS BASES EPISTEMOLÓGICAS DE LA LINGÜIISTICA COGNITIVA*}

IRAIDE IbARRETXE-ANTUÑANO

(Universidad de Zaragoza)

En este trabajo se exponen sucintamente los principales principios teóricos y metodológicos de la lingüística cognitiva, y se relacionan, en la medida de lo posible, con algunas de las ideas lingüísticas, así como con algunas de las críticas, especialmente sobre algunos aspectos más controvertidos (categorización, metáfora), que han sido propuestas por diversos autores y escuelas a lo largo de la historia de la lingüística, pero con especial atención al ámbito románico.

El tema de este trabajo, así como el título, son un guiño muy especial al profesor José Francisco Val Álvaro, gran conocedor de teorías lingüísticas de todo tipo y condición, y aunque no mi maestro de iure, sí mi maestro de facto desde que estoy en Zaragoza. Tanto el tema como el título surgen de varias conversaciones en las que discutíamos sobre las semejanzas y las di-

* Este trabajo se encuadra dentro del proyecto MovEs, financiado por el Ministerio de Ciencia e Innovación del Gobierno de España (FFI2010-14903). 
ferencias entre los modelos formalistas y los funcionalistas, de 'lo malo' de Chomsky y 'lo bueno' de la lingüística cognitiva, y viceversa. En una de ellas, donde creo recordar que, al azote del cierzo zaragozano, habíamos llegado a la conclusión de que en el fondo todas las teorías tienen algo aprovechable y que no son tan distintas unas de otras, sino complementarias, Pepe planteó la posibilidad de que «si Coseriu viviera sería cognitivista». En este artículo retomo esta idea y, siempre con las limitaciones de no dedicarme a la historiografía lingüística, me propongo escudriñar en los posibles antecedentes de la lingüística cognitiva en general; ${ }^{1}$ antecedentes, eso sí, no entendidos como los precursores en los que después desemboca la lingüística cognitiva, sino en el sentido como define el $D R A E$ de "Acción, dicho o circunstancia que sirve para comprender o valorar hechos posteriores». Este trabajo, además de ser un sincero y cariñoso homenaje a Pepe, tiene como objetivo mostrar que los modelos lingüísticos no son 'nuevos' sino inteligentes reinterpretaciones y reformulaciones de ideas anteriores, y que, a veces, los defensores y los detractores de los mismos no se dan cuenta de ello.

\section{La lingüística cognitiva: un 'nuevo' 'movimiento' lingüístico}

La lingüística cognitiva es un movimiento lingüístico que concibe $e l$ lenguaje como un fenómeno integrado dentro de las capacidades cognitivas humanas (Croft y Cruse 2004; Evans y Green 2006; Geeraerts y Cuyckens 2007; Ibarretxe-Antuñano y Valenzuela en prensa). A pesar de que se suele considerar un modelo que nace en los ochenta en la costa oeste de los Estados Unidos (U. California), el germen de la lingüística cognitiva también se estaba desarrollando en Europa, especialmente en Alemania y en los Países Bajos. Posiblemente, una de las diferencias más importantes entre los lingüistas de un lado y otro del Atlántico se encuentra en su bagaje lingüístico y en sus diferentes trayectorias como lingüistas. Mientras que en Europa provienen más de una larga tradición funcionalista (en sus dife-

1 He procurado sobre todo dar el mayor número posible de referencias de publicaciones que han tratado este tema, para que el lector interesado se dirija a estas fuentes y, así, sobrepase las limitaciones de este trabajo. 
rentes versiones), en Estados Unidos, la mayoría de estos se han formado dentro de la escuela generativista chomskiana. De hecho, debemos recordar que el propio Lakoff junto con Ross y McCawley fueron los impulsores de la frustrada semántica generativa (McCawley 1976).

Este hecho es importante porque algunas de las críticas que ha recibido la lingüística cognitiva, especialmente por parte de lingüistas europeos, están relacionadas precisamente con la falta de perspectiva histórica de la misma (véase Jäkel 1999; Nerlich y Clark 2007); en otras palabras, algunos autores le han achacado a ciertos teóricos de la lingüística cognitiva su falta de (re)conocimiento de las ideas lingüísticas tradicionales europeas. Hasta cierto punto, esta falta es totalmente cierta, el (re)conocimiento no existe, pero también algunos de los críticos muestran un verdadero desconocimiento de las bases epistemológicas de la lingüística cognitiva, que hacen que estas críticas, aunque válidas, se queden en superficiales (Martínez del Castillo 2008).

Además de estos inicios, también es importante destacar que la lingüística cognitiva, a diferencia de otros modelos lingüísticos que son bastante homogéneos y siguen las doctrinas de un 'líder' consumado (p. ej., el generativismo y Chomsky), no es una teoría lingüística unificada sino que se suele considerar un 'movimiento' o 'corriente' que engloba a su vez diversos submodelos ${ }^{2}$ que tratan de diversos aspectos del lenguaje y tienen unos objetivos ligeramente diferentes, pero, eso sí, que comparten unos supuestos y unos principios sobre el funcionamiento de la lengua y el lenguaje que vamos a resumir en la siguiente sección.

\section{Principios epistemológicos y metodológicos de la lingüística cognitiva y sus antecedentes}

Posiblemente, el principio epistemológico más importante de la lingüística cognitiva es la premisa de que el lenguaje es una capacidad integrada en la cognición general, ya que se entiende como el resultado de las habili-

2 El lector interesado en estos submodelos puede consultar Ibarretxe-Antuñano y Valenzuela (en prensa); en esta obra en español se ofrece para cada submodelo una caracterización y una bibliografía básica. 
dades cognitivas generales tales como la memoria, el razonamiento, la categorización o la atención. Este principio se recoge en el llamado 'compromiso cognitivo' (Lakoff 1990: 40) que señala que todo cognitivista tiene que estar preparado para aceptar esta unión entre el lenguaje y las otras facultades cognitivas, ya que tanto la teoría como la metodología han de ser consistentes con lo que se conoce empíricamente sobre la cognición, el cerebro y el lenguaje. Es decir, entre el lenguaje y los otros procesos mentales existe solamente una diferencia de grado. Como consecuencia, los principios lingüísticos se deben investigar en relación con otras facultades mentales y además cualquier explicación de los diferentes niveles de análisis lingüísticos (fonología, semántica, sintaxis...) han de llevarse a cabo de una forma simultánea.

Esta opción conlleva una serie de consecuencias. Una de ellas es el rechazo del modularismo, es decir, analizar el lenguaje como un módulo autónomo. Este rechazo choca con algunos modelos más formalistas, al menos en sus inicios, como la lingüística generativa tradicional (Chomsky 1988), semántica fregueana (Geach y Black 1952) y la semántica de modelos teóricos de Montague (Cann 1993; Dowty et al. 1981), ya que entienden el conocimiento de las estructuras y reglas lingüísticas como independientes de otros procesos mentales, y proponen que los diferentes niveles de análisis lingüístico son módulos independientes.

Otro de los principios básicos de la lingüística cognitiva es la organización de la estructura conceptual. En este modelo, todo concepto está basado en una estructura de conocimiento, a la que se denomina genéricamente dominio conceptual, y que ha recibido según el autor otras etiquetas como 'marco semántico' (Fillmore 1982, 1985), 'modelo cognitivo' (Lakoff 1987), entre otros. A pesar de las diferencias entre estas etiquetas, la idea principal es que todo concepto necesita estar cimentado (o contextualizado) en una estructura coherente de conocimiento basado en nuestra experiencia humana, y según autores como Taylor (1999: 41) también en un conocimiento más lingüístico que da cuenta de las relaciones paradigmáticas y sintagmáticas de ese concepto. Normalmente, estas esquematizaciones del conocimiento se guardan en la memoria a largo plazo y siempre se han de filtrar a través de una base cultural. En términos de Langacker (1987), este conocimiento es el necesario, es el fondo, sobre el cual se puede perfilar el concepto que estamos tratando; operación que en la termino- 
logía de Langacker se denomina perfilamiento (profiling en inglés) y consiste en 'segregar' o 'filtrar', de una manera más o menos automática e inconsciente que puede llegar a manipularse, el conocimiento que juzgamos como más relevante en una determinada situación. La necesidad de un dominio cognitivo es fundamental, ya que cualquier concepto ha de estar siempre entendido no solo como una simple «designación» (un perfilamiento), sino también como una "significación» en términos estructuralistas (véase Coseriu 1990 y la réplica en Taylor 1999; Willems 2011).

La organización de la estructura conceptual y el perfilamiento langackeriano son claramente elementos que la lingüística cognitiva ha tomado de la psicología gestáltica (Ash 1985; Köhler 1917, 1924, 1969; Rubin 1914; von Ehrenfels 1890), y que también estaban presentes en la psicología de Wundt $(1880,1900,1901)$. Aunque la influencia de la psicología gestáltica está clara en este modelo, autores como Nerlich y Clark (2007: 600), también nos recuerdan que otros lingüistas como Bühler (1934 [1950]) y su concepto de 'esfera', anteriores al movimiento cognitivista, ya apuntaban que el significado - el concepto en lingüística cognitiva - ha de estar cimentado en otras estructuras de conocimiento.

La categorización humana, es decir, la habilidad de juzgar si un elemento en particular pertenece o no a una categoría en concreto, es otro de los mecanismos fundamentales en la lingüística cognitiva y que ejemplifican esa relación compartida entre la facultad lingüística y otras facultades cognitivas. Se parte del presupuesto de que las categorías lingüísticas son, en realidad, otro tipo de categorías cognitivas, razón por la cual para saber cómo funciona la categorización lingüística es necesario saber cómo funciona la categorización a nivel global. Se adopta el modelo de categorización propuesto en los ańos setenta por Rosch y su equipo (Rosch 1973, 1978; Mervis y Rosch 1981; véanse también Kleiber 1995 y Taylor 1995 [2009], para un análisis crítico). Las categorías en este modelo, a diferencia de aproximaciones más estructuralistas cercanas a las propuestas aristotélicas basadas en un conjunto de rasgos suficientes y necesarios, se consideran entidades graduales con límites difusos y la categorización como un proceso mucho más flexible y matizado. Una interpretación que Geeraerts (1988) señala como mucho más afín a autores pertenecientes a la tradición histórico-filológica europea como Breál (1897), Darmesteter (1887), Paul (1880), Stern (1931) y Wundt (1900), entre otros. 
Rosch y su equipo, a través de datos experimentales, establecen la categorización humana en dos dimensiones: la dimensión vertical de la categorización (o teoría del nivel básico) que se basa en el nivel de detalle o de inclusión de los miembros que forman una categoría y la dimensión horizontal de la categorización (o teoría de prototipos) en la que lo importante es la representatividad o prototipicidad de los elementos que forman la categoría. En esta última, los miembros se organizan de acuerdo con una escala gradual de prototipicidad, donde en un extremo está el prototipo que es el mejor ejemplo porque comparte la mayoría de las características definitorias de la categoría, y en el otro extremo opuesto, el marginal, que comparte menos rasgos. La propuesta de categorización de prototipos está basada en parte en el trabajo de Wittgenstein (1953) y en lo que este filósofo denominaba semejanza de familia. Las relaciones entre los miembros de una categoría serían como las que se encuentran en los miembros de una familia, en la que un hijo puede parecerse a su padre, y este al suyo, pero no implica que necesariamente, el nieto y el abuelo se parezcan. Este mismo razonamiento se aplica a la estructuración interna de una categoría, el miembro central no tiene que estar directamente relacionado con el marginal, ni siquiera con los otros miembros de la categoría. Estos se incluyen en la categoría a través de diferentes grados de semejanza, es decir, que comparten algunas características, pero no necesariamente todas y cada una de ellas.

Hasta hace poco, de hecho, la lingüística cognitiva se identificaba exclusivamente con la semántica de prototipos en el mundo hispánico (véanse Casas Gómez 2004: 133-138; Coseriu 1990; Gutiérrez Ordóñez 2002: cap. 15), lo cual, como estamos dejando patente, es un error, ya que es solamente uno de los elementos que componen el conglomerado de la lingüística cognitiva. Estos autores normalmente critican la semántica de prototipos porque confunde «las significaciones con las cosas designadas "[...] al saber acerca de las cosas [... y no] al saber propiamente lingüístico» (Coseriu 1990: 267). Sin embargo, la mayoría de estas críticas se explican (y se desechan) precisamente porque estos autores siguen partiendo de puntos de vista diferentes. Por un lado, nos encontramos con la creencia de que el saber lingüístico está desligado de otros tipos de conocimiento (p. ej., el enciclopédico) y de otros ámbitos (como dice Casas Gómez [2004: 137]: «la noción de prototipo nace en el ámbito psicológico del análisis de los conceptos y no de los significados lingüísticos»). Por otro 
lado, tenemos también la división tradicional estructuralista entre Lingüística de la Lengua y Lingüística del Habla — que no se admite en lingüística cognitiva - y la subjetiva interpretación de que la primera es la fundamental, la verdadera Lingüística. Basten las palabras de Gutiérrez Ordónez al final de su revisión: «La Lingüística Cognitiva constituye una aproximación digna de consideración si se aplica a dar cuenta de este aspecto: cómo desmontamos en el discurso los mensajes. Si, por el contrario, persiste en su empeño de ser aplicada al campo de la Lingüistica como ciencia, los resultados serán desastrosos» (2002: 387, cursivas mías). ${ }^{3}$

Otra de las capacidades cognitivas que comparte el lenguaje es la imaginación, la cual permite que experiencias más abstractas, que no se pueden aprehender de forma directa, se experimenten a través de experiencias más directas y aprehensibles (Johnson 1987: 172). Desde este punto de vista, surgen dos de los mecanismos cognitivos básicos, la metáfora conceptual y la metonimia conceptual. Ambos se definen como correspondencias o proyecciones entre dominios conceptuales (áreas de conocimiento como hemos definido más arriba). La diferencia radica en que en la metáfora estos dos dominios, el dominio fuente y el dominio meta, son diferentes (p. ej., VISIÓN y COGNICIÓN), mientras que en la metonimia estas correspondencias se realizan dentro de un mismo dominio (p. ej., PRODUCTOR y PRODUCTO). Estos conceptos de metáfora y metonimia se diferencian radicalmente de interpretaciones anteriores que las consideran figuras o recursos retóricos utilizados por expertos para embellecer la lengua de una manera consciente (Halliday 1985: 319-20) o como el resultado de implicaturas contextuales (Papafragou 1996; Sperber y Wilson 1986). La metáfora y metonimia conceptuales son fenómenos de cognición que se dan en el lenguaje cotidiano y que se lexicalizan a través de expresiones metafóricas (no veo lo que me dices) y metonímicas (me he comprado un porsche) (Lakoff y Johnson 1980). De ahí, que se distinga entre metáfora/metonimia conceptual (normalmente en versalitas) y la expresión metafórica/metonímica (en cursiva). También se suele decir que estas proyecciones suelen ser inconscientes y comunes al ser humano, universales; aunque recientemente estas dos características se están criticando dentro de la lingüística cogniti-

3 Véanse Taylor (1999) y Willems (2011) para una comparación crítica entre la lingüística cognitiva (especialmente la gramática cognitiva) y el estructuralismo. 
va, ya que en parte estos procesos de correspondencias entre dominios/ dentro de un dominio tienen que ser también en parte conscientes (Itkonen 2008; Zlatev 2008), y la universalidad tiene siempre que filtrarse a través de la cultura en la que se desarrolla esa metáfora (Caballero e Ibarretxe-Antuñano en prensa). La metáfora ha sido una de las áreas más estudiadas dentro de la lingüística cognitiva (y más criticadas dentro y fuera de la misma), pero como indican algunos autores como Jäkel (1999) muchas de las ideas que subyacen al concepto de metáfora conceptual ya se pueden encontrar con algunas diferencias en otros autores. Por ejemplo, el reconocimiento de que las metáforas se usan en la vida cotidiana por gente ordinaria ya está presente en filósofos como Hartung (1831), y más recientemente, Blumenberg $(1960,1971,1979)$, quien además las ve como estructuras de pensamiento. Otros como Kant (1790), aunque no usan el término metáfora sino analogía, también observan que se realizan transferencias entre dos dominios que no tienen relación gracias a la sensualización simbólica. Para Jäkel (1999), sin embargo, la propuesta de Weinrich (1976) es la que más se acerca a la metáfora conceptual, al considerar que las metáforas son enlaces entre dos dominios conceptuales, el que dona la imagen y el que recibe la imagen, y que no son ejemplos aislados. Recientemente, la teoría de la metáfora conceptual también ha sido abordada desde la perspectiva de la lingüística de Coseriu (véase Faur en prensa $a, b$ ), quien ya en 1952 abordaba este tema, aunque no de una forma sistemática, y al igual que la lingüística cognitiva consideraba que la metáfora está relacionada con la cognición («el conocimiento lingüístico es muchas veces conocimiento metafórico», Coseriu 1952/1985: 80), tiene carácter universal y se corresponde con la imaginación («cierta unidad universal de la fantasía humana, por encima de las diferencias idiomáticas, étnicas o culturales", ob. cit., 80). Sin embargo, una de las diferencias fundamentales es que la metáfora en esta teoría sigue siendo algo lingüístico exclusivamente, al contrario que en la lingüística cognitiva (recuérdese metáfora conceptual vs. expresión metafórica). ${ }^{4}$ Faur (en prensa $a, b$ ) en su comparación de ambas teorías señala que la teoría de la metáfora no explica la finalidad

4 Coseriu (1990) (véase también Faur en prensa b; Zlatev en prensa) sostiene que la lingüística cognitiva identifica el significado lingüístico solamente con la designación, de ahí que este autor rechace algunas de las consideraciones básicas de la lingüística cognitiva, ya que, en su modelo, este va más allá porque incluye la designación, el significado y el sentido (Coseriu 1977, 1978, 1988, entre otros; véase también Willems 2011). 
de las metáforas, ni tampoco cómo se crean; pero que la propuesta couseriana, que considera la creatividad metafórica como un proceso (energeia) y no como producto (ergon), podría resolverlos.

Otro de los principios teóricos básicos de la lingüística cognitiva es que el lenguaje es simbólico por naturaleza. Según Langacker (1987), el lenguaje es simbólico porque está basado en la asociación entre la representación semántica y la representación fonológica. La asociación entre estos dos polos se refiere a la concepción saussuriana del signo lingüístico; es fácil ver la 'imagen acústica' que distinguía Saussure (1916) en la representación fonológica y el 'concepto' en la representación semántica (véase Willems 2011: 33-40). Sin embargo, el concepto de signo lingüístico y la relación entre estos dos polos es diferente en lingüística cognitiva. Por un lado, como señala Taylor (1999: 19), el signo lingüístico no se reduce solamente a los lexemas, sino que se extiende tanto a los patrones de formación de palabras (morfología) como a la formación de estructuras más complejas (sintaxis), que también son de naturaleza simbólica aunque en diferentes grados de complejidad.

Por otro lado, esta relación entre estos polos se diferencia de la saussuriana en la interpretación del concepto de arbitrariedad del signo lingüístico. Aunque es cierto que existe cierta arbitrariedad en la asociación entre los elementos lingüísticos y su significado, especialmente la que tiene que ver con la convencionalización, esta arbitrariedad está restringida. Para los cognitivistas, el lenguaje no se estructura arbitrariamente, es decir, el tener un significante que realice un significado en una lengua determinada no es arbitrario sino motivado (véase también la propuesta de los diferentes tipos de motivación propuesta por Ullman [1965]). Según la lingüística cognitiva, el lenguaje está motivado, está corporeizado. La corporeización (o embodiment en inglés) se define como la motivación más o menos directa del lenguaje en nuestra experiencia corpórea, física, social y cultural (Johnson 1987). Esta noción de corporeización encuentra sus raíces en la tradición fenomenológica (Merleau-Ponty 1962, 1963; Varela, Thompson y Rosch 1993; véase Zlatev 2010 para una comparación exhaustiva entre la lingüística cognitiva y la fenomenología) y postula que las categorías lingüísticas no son abstractas e independientes de los seres humanos, sino que las creamos basándonos en experiencias concretas y siempre restringidos por nuestro propio cuerpo. La utilización del con- 
cepto de corporeización y motivación ha sido fundamental en el desarrollo de la semántica cognitiva, especialmente en estudios sobre polisemia, pero también ha sido criticado dentro y fuera de la lingüística cognitiva (Caballero e Ibarretxe en prensa; Sinha y Rodríguez 2008; Zlatev 2005, 2007, 2008, 2010, en prensa). Una de las más insistentes, especialmente en los últimos años, es que en muchas ocasiones la parte socio-cultural de la corporeización se ha olvidado, ha pasado a un segundo plano, lo cual ha originado que en muchos casos se sobrevalore el carácter universal de algunos mecanismos cognitivos como la metáfora que hemos comentado más arriba. En realidad, si es cierto que el lenguaje está motivado por nuestra experiencia física, por un lado, es normal que pensemos que hay cierta universalidad; todos los seres humanos tenemos el mismo cuerpo y las mismas capacidades cognitivas, pero no se puede olvidar que vivimos en unos contextos diferentes, y que nuestras interacciones se dan también en unas situaciones distintas.

La afirmación de que el lenguaje está basado en el uso es otro de los pilares de la lingüística cognitiva. Se puede interpretar de dos formas diferentes. Por un lado, con la idea de que toda afirmación o hipótesis teórica debe estar no solo avalada sino fundamentada en datos empíricos sólidos. De ahí, que la utilización de corpus y de métodos empíricos sea imprescindible (González-Márquez 2007; Gries y Stefanowitsch 2004; Stefanowitsch y Gries 2005). Por otro lado, el más importante, con la propuesta de que la abstracción de unidades simbólicas del uso regular del lenguaje es la que fundamenta y constituye el conocimiento del lenguaje de los hablantes. Es decir, los hablantes de una determinada lengua según se van topando y utilizando una determinada estructura (palabra y/o construcción), van apre(he)ndiendo cómo se ha de utilizar esta estructura (sus contextos de uso, su contexto lingüístico, etc.). En definitiva, lo que se propone es que a partir de nuestra experiencia lingüística continua se crea o se extrapola nuestra 'gramática' (Barlow y Kemmer 2000). El hecho de que se postule que el lenguaje está basado en el uso hace que las dicotomías tradicionales como la saussuriana entre lengua y habla, o la chomskiana entre competencia y actuación se rechacen y desaparezcan, porque los conocimientos del hablante y las abstracciones generales de la lengua se basan en el uso individual y colectivo de las mismas. En realidad, esta idea de que no se puede 'desechar' la parte de la lengua o de la competencia a la hora de describir el sistema tampoco es nueva. Coseriu ya propone una revisión y 
crítica minuciosa de estos conceptos (véase especialmente Coseriu 1988, pero también 1967, 1977, 1978), y en todos sus escritos siempre incide en que se tiene que partir de una lingüística del habla para llegar a una lingüística de la lengua. A pesar de estas similitudes, el hecho de seguir confiando plenamente en lo puramente lingüístico hace que siga habiendo diferencias entre estas dos teorías.

\section{Conclusiones}

En este trabajo hemos querido dar una visión global de la lingüística cognitiva y relacionarla con otras corrientes y con otros estudios anteriores en la medida de lo posible. Hemos partido de dos ideas fundamentales: por un lado, la lingüística cognitiva es un conglomerado de diversos submodelos y, por otro lado, todos estos submodelos comparten en mayor o menor medida algunos principios metodológicos y teóricos (p. ej., lenguaje es cognición, simbólico y basado en el uso) que en muchas ocasiones se pueden encontrar ya discutidos, intuidos o esbozados en otras teorías y modelos anteriores, aunque nunca en la forma en la que se presentan conjuntamente en esta corriente lingüística. No sabemos si Coseriu, hoy en día, sería cognitivista, posiblemente seguiría habiendo diferencias, pero quizás tal como parecen revelar algunos autores modernos (Faur, Willems, Zlatev), habría muchos puntos de encuentro en los que ambas teorías podrían llegar a converger; algo que, por otra parte, también sería posible con otros modelos tanto funcionalistas como formalistas, a veces considerados tan divergentes. Las teorías lingüísticas, en definitiva, no solamente son complementarias, sino que además ninguna de ellas es incuestionable, porque como diría Karl Popper «el aumento del conocimiento depende por completo de la existencia del desacuerdo».

\section{Referencias}

Ash, M. (1985): «Gestalt psychology: Origins in Germany and reception in the United States", en C. E. Buxton (ed.), Points of view in the modern history of psychology, Londres, Academic Press: 295-344.

Barlow, M. y S. Kemmer (eds.) (2000): Usage-based Models of Language, Cambridge, Cambridge University Press. 
Blumenberg, H. (1960): «Paradigmen zu einer Metaphorologie», Archiv für Begriffsgeschichte, 6: 7-142.

- (1971): «Beobachten an Metaphern», Archiv für Begriffsgeschichte, 15: 161-214.

- (1979): Schiffbruch mit Zuschauer. Paradigma einer Daseinsmetapher, Frankfurt am Main, Suhrkamp.

BrÉAL, M. (1897): Essai de sémantique, París, Hachette.

BüHLeR, K. (1934 [1950]): Teoría del lenguaje, Madrid, Revista de Occidente.

Caballero, R. e I. IbarretXe-Antuñano (en prensa): «Ways of perceiving and thinking: Re-vindicating culture in conceptual metaphor research", Cognitive Semiotics, 8/9.

Cann, R. (1993): Formal Semantics, Cambridge, Cambridge University Press.

Casas Gómez, M. (2004): Los niveles del significar, Cádiz, Universidad de Cádiz Servicio de Publicaciones.

Сномsку, N. (1988): Language and Problems of Knowledge. The Managua Lectures, Cambridge, Mass., MIT Press.

Coseriu, E. (1952/1985): «La creación metafórica en el lenguaje», en E. Coseriu, El hombre y su lenguaje. Estudios de teoría y metodología lingüistica, Madrid, Gredos: 66-102.

- (1967): Teoría del lenguaje y lingüistica general: cinco ensayos, Madrid, Gredos.

- (1977): Principios de semántica estructural, Madrid, Gredos.

- (1978): Gramática, semántica, universales. Estudios de lingüistica funcional, Madrid, Gredos.

- (1988): Competencia lingüistica. Elementos de la teoría del hablar, Madrid, Gredos.

- (1990): «Semántica estructural y semántica cognitiva», en Profesor Francisco Marsá: jornadas de filologia, Barcelona, Universitat de Barcelona: 239-282.

Croft, W. y D. A. Cruse (2004): Cognitive Linguistics, Cambridge, Cambridge University Press.

Darmesteter, A. (1887): La vie des mots étudiée dans leurs significations, París, Delagrave.

Dowty, D. R., R. E. Wall y S. Peters (1981): Introduction to Montague Semantics, Dordrecht, D. Reidel.

Evans, V. y M. Green (2006): Cognitive Linguistics, Edinburgh, Edinburgo University Press.

Faur, E. (en prensa $a$ ): "Conceptual metaphor and integral semantics», en Proceedings of the Second International Congress "Eugenio Coseriu: Contemporary Perspectives», Cluj-Napoca, Rumanía, 23-25 de septiembre de 2009.

- (en prensa $b$ ): «Why Conceptual Metaphor Theory Needs Integral Semantics? Rethinking Conceptual Metaphor within an Integral Semantics Framework», Cognitive Semiotics, 8/9. 
Fillmore, C. (1982): «Frame semantics», en Linguistic Society of Korea (ed.), Linguistics in the Morning Calm, Seúl, Hanshin Publishing: 111-137.

- (1985): «Frames and the semantics of understanding», Quaderni di Semantica, 6: 222-254.

GeACH, P. y M. Black (eds.) (1952): Translations from the Philosophical Writings of Gottlob Frege, Oxford, Blackwell.

Geeraerts, D. (1988): "Cognitive grammar and the history of lexical semantics», en B. Rudzka-Ostyn (ed.), Topics in Cognitive Linguistics, Ámsterdam/Filadelfia, John Benjamins: 647-694.

- y H. Cuyckens (eds.) (2007): Handbook of Cognitive Linguistics, Oxford, Oxford University Press.

González-Márquez, M., I. Mittelberg, S. Coulson y M. J. Spivey (eds.) (2007): Methods in cognitive linguistics, Ámsterdam/Filadelfia, John Benjamins.

Gries, S. y A. Stefanowitsch (2004): Corpora in cognitive linguistics. The syntaxlexis interface, Berlín/Nueva York, Mouton de Gruyter.

Gutiérrez Ordóñez, S. (2002): De pragmática y semántica, Madrid, Arco/ Libros.

Halliday, M. A. K. (1985): An Introduction to Functional Grammar, Londres, Baltimore y Melbourne, Edward Arnold.

Hartung, J. A. (1831): Ueber die Casus, ihre Bildung und Bedeutung, in der griechischen und lateinischen Sprache, Erlangen, Palm y Enke.

IbarretXe-Antuñano, I. y J. Valenzuela (en prensa): Lingüistica Cognitiva, Barcelona, Anthropos.

Itronen, E. (2008): «The role of consciousness in linguistics», Journal of Conciousness Studies, 15.6: 10-31.

JäKEL, O. (1999): «Kant, Blumenberg, Weinrich. Some forgotten contributions to the cognitive theory of metaphor", en R. W. Jr. Gibbs y G. J. Steen (eds.), Metaphor in Cognitive Linguistics, Ámsterdam/Filadelfia, John Benjamins: 9-27.

Johnson, M. (1987): The Body in the Mind: The Bodily Basis of Meaning, Imagination, and Reason, Chicago, Chicago University Press.

Kant, I. (1790 [1981]): Crítica del juicio, Madrid, Espasa-Calpe.

Kleiber, G. (1995): La semántica de los prototipos. Categoría y sentido léxico, Madrid, Visor Libros.

KöHLER, W. (1917): Intelligenzprüfungen an Anthropoiden, Berlín, Springer Verlag.

- (1924): Die physischen Gestalten in Ruhe und im stationären Zustand: Eine naturphilosophische Untersuchung, Erlangen, Verlag der Philosophishen Akademie.

- (1969): Psicología de la forma, Buenos Aires, Paidós. 
LAKoff, G. (1987): Women, fire and dangerous things. What categories reveal about the mind, Chicago, Chicago University Press.

- (1990): «The invariance hypothesis: is abstract reason based on image-schemas?», Cognitive Linguistics, 1.1: 39-74.

- y M. Johnson (1980): Metaphors we live by, Chicago, Chicago University Press.

LANGACKeR, R. W. (1987): Foundations of cognitive grammar, Vol. 1: theoretical prerequisites, Stanford, Stanford University Press.

Martínez del Castillo, J. (2008): La lingüistica cognitiva. Análisis y revisión, Madrid, Biblioteca Nueva.

McCaWley, J. D. (ed.) (1976): Syntax and semantics 7: notes from the linguistic underground, Nueva York, Academic Press

Merleau-Ponty, M. (1962): Phenomenology of Perception, trad. Colin Smith, Londres, Routledge \& Kegan Paul.

- (1963): The Structure of Behaviour, trad. Alden Fisher, Boston, Beacon Press.

Mervis, C. B. y E. Rosch (1981): "Categorization of natural objects», Annual Review of Psychology, 32: 89-115.

Nerlich, B. y D. D. Clarke (2007): "Cognitive linguistics and the history of linguistics», en D. Geeraerts y H. Cuyckens (eds), Handbook of Cognitive Linguistics, Oxford, Oxford University Press: 489-607.

Paul, H. (1880): Prinzipien der Sprachgeschichte, Halle, Niemeyer.

Papafragou, A. (1996): «On metonymy», Lingua, 99.4: 169-195.

Rosch, E. (1973): «Natural Categories», Cognitive Psychology, 4: 328-50.

- (1978): «Principles of categorization», en E. Rosch y B. B. Lloyd (eds.), Cognition and categorization, Hillsdale, NJ, Erlbaum: 27-48.

Rubin, E. (1914): «Die visuelle Wahrnehmung von Figuren», en F. Schumman (ed.), Bericht über den 6. Kongress für experimentelle Psychologie, Leipzig, Barth.

Saussure, F. de (1916): Cours de Linguistique Général, C. Bally y A. Sechehaye (eds.), con la colaboración de A. Riedlinger, París/Lausana, Payot.

Sinha, C. y C. Rodríguez (2008): «Language and the signifying object: from convention to imagination", en J. Zlatev, T. Racine, C. Sinha y E. Itkonen (eds.), The shared mind: perspectives on intersubjectivity, Ámsterdam/Filadelfia, John Benjamins: 357-378.

Sperber, D. y D. Wilson (1995 [1986]): Relevance. Communication and Cognition, Oxford, Mass., Blackwell.

Stefanowitsch, A. y S. Gries (eds.) (2005): Corpora in cognitive linguistics: conceptual mappings, Ámsterdam/Filadelfia, John Benjamins.

Stern, G. (1931): Meaning and change of meaning, Göteborg, Elanders.

TaYlor, J. (1995 [2009]): Linguistic Categorisation. Prototypes in Linguistic Theory, Cambridge, Cambridge University Press. 
TAYLOR, J. (1999): "Cognitive semantics and structural semantics», en A. Blank y P. Koch (eds.), Historical semantics and cognition, Berlín, Mouton de Gruyter: $18-48$.

Ullman, S. (1965): Semántica. Introducción a la ciencia del significado, Madrid, Aguilar.

Varela, F. J., E. Thompson y E. Rosch (1993): The Embodied Mind. Cognitive Science and Human Experience, Cambridge, Mass., MIT Press.

Von Ehrenfels, C. (1890): «Über Gestaltqualitäten». Vierteljahrschrift für wissenschaftlichen Philosophiek, 14: 249-292.

WeInrich, H. (1976): Sprache in Texten, Stuttgart, Klett.

Willems, K. (2011): «Meaning and interpretation: The semiotic similarities and differences between Cognitive Grammar and European structural linguistics", Semiotica, 185: 1-50.

Wittgenstein, L. (1953): Philosophical Investigations, Nueva York, MacMillan.

Wundt, W. (1880): Logik: Eine Untersuchung der Prinzipien der Erkenntnis und der Methoden Wissenschaflicher Forschung, Stuttgart, Enke.

- (1900): Völkerpsychologie: Eine Untersuchung der Entwicklungsgestze von Sprache, Mythus und Sitte, Leipzig, Engelmann.

- (1901): Sprachgeschichte und Sprachpsychologie: Mit Rücksicht auf B. Delbrücks «Grundfragen der Sprachforschung», Leipzig, Engelmann.

Zlatev, J. (2005): "What's in a schema? Bodily mimesis and the grounding of language», en B. Hampe (ed.), From perception to meaning: image schemas in cognitive linguistics, Berlín, Mouton de Gruyter: 313-343.

- (2007): «Embodiment, language and mimesis», en T. Ziemke T, J. Zlatev y R. Frank (eds.), Body, language and mind, vol 1: Embodiment, Berlín, Mouton de Gruyter: 297-338.

- (2008): «The dependence of language and consciousness», Journal of Conciousness Studies, 15.6: 34-62.

- (2010): «Phenomenology and cognitive linguistics», en D. Schmicking y S. Gallagher (eds.), Handbook of Phenomenology and Cognitive Sciences, Dordrecht/Nueva York, Springer: 415-446.

- (en prensa): «From cognitive to integral linguistics and back again», Intellectica. 



\section{EL CONCEPTO DE LENGUA EN LA LINGÜÍSTICA RECIENTE: BREVE REFLEXIÓN SOBRE UN MALENTENDIDO DURADERO}

José Luis Mendívil Giró (Universidad de Zaragoza)

\section{Introducción}

Un científico que se acerque a la lingüística teórica actual desde fuera contemplará un campo fragmentado, enfrentado y muchas veces contradictorio. Si lee a Chomsky o a Pinker, acabará concluyendo que el lenguaje humano es un órgano mental característico de la especie y que, por tanto, debe ser abordado científicamente como cualquier otro órgano del cuerpo, esto es, como cualquier otro objeto natural. Leerá también que todas las lenguas humanas son variaciones superficialmente distintas de un único sistema de conocimiento, que es uniforme en la especie, dado que tiene un estrecho condicionamiento natural. Leerá que el lenguaje es esencialmente innato y que el desarrollo de una lengua en la mente y el cerebro del niño se parece más al crecimiento de los tejidos o al desarrollo del sistema visual que al aprendizaje de normas y convenciones culturales.

$\mathrm{Si}$, por el contrario, aborda algún material inspirado por la tradición funcionalista o, más recientemente, por la llamada lingüística cognitiva (si lee, por ejemplo, a Croft, a Levinson o a Tomasello) descubrirá que las lenguas humanas son profundamente distintas, dado que cada lengua humana es una 
solución histórica distinta a un mismo conjunto de tareas o funciones comunicativas y cognitivas. Aprenderá que la estructura de cada lengua es extraída por el nińo a partir de los datos del entorno junto con el resto de su cultura, y que en esa tarea se sirve de sistemas de aprendizaje comunes a los empleados para el desarrollo de otros sistemas de creencias y de conocimiento. Incluso leerá que cada lengua condiciona el pensamiento de manera distinta.

No debe ignorarse que tras estos dos grandes bloques de pensamiento residen diferentes concepciones de cuál es la naturaleza humana, de cómo se forman los sistemas de conocimiento que caracterizan a nuestra especie e incluso de qué es la propia ciencia. Sin embargo, este antiguo enfrentamiento es también consecuencia de graves malentendidos sobre cuál es la naturaleza última de las lenguas, el objeto de estudio de la lingüística. En esta breve contribución intentaré mostrar que esta situación deplorable de nuestra disciplina viene causada por la incapacidad de algunas corrientes actuales para reconocer que por debajo de una 'realidad sociolingüística' existe una 'realidad biolingüística' y que, reconocida dicha dualidad, más que de incompatibilidad entre modelos, habría que hablar de cierta complementariedad.

\section{Lingüistas-moleculares y lingüistas-naturalistas}

A partir del momento en el que en marzo de 1953 Francis Crick, acompañado de James Watson, entró en el Eagle, su pub favorito de Cambridge, revelando — a la vez que pedía una pinta - que habían descubierto «el secreto de la vida», la biología se partió en dos. Había nacido la biología molecular. Los biólogos mayores se resistieron y se ensayó una división entre la macrobiología y la microbiología, pero la suerte de la primera estaba echada. La élite de la investigación biológica dejó de hablar de rumiantes, de reinos y de migraciones y se centró en genes, proteínas y aminoácidos. Por así decirlo, el pensamiento analógico de Darwin fue sustituido por la digitalización de la vida en moléculas, reacciones químicas y hasta fórmulas matemáticas, abrazando para siempre la química y la física. Los cuadernos de campo y los prismáticos quedaron relegados por los microscopios y las probetas. Y los 'macrobiólogos' se convirtieron en naturalistas. Para el naturalista, la especie es el centro de su universo. Para el biólogo molecular, la especie es un dato más, un factor emergente en el que se empaqueta lo que le interesa, pero el biólogo moderno no opera 
con especies, sino con individuos y, sobre todo, con sus componentes y sus intrincadas relaciones.

Todo esto es relevante porque, desde el punto de vista biolingüístico, las lenguas humanas se parecen mucho a las especies naturales. Ya Darwin se percató de ello y declaró que la evolución de unas y de otras era «curiosamente paralela» («curiosamente la misma» llegó a escribir). ${ }^{1} \mathrm{Y}$, en efecto, como las especies naturales, las lenguas (eso que llamamos ruso o alemán) no son sino agrupaciones de 'individuos' semejantes. Como las especies, las lenguas cambian, se separan en ramas descendentes y, con frecuencia, se extinguen.

Pero la semejanza entre lenguas y especies no se queda ahí. También hay, por así decirlo, lingüistas-moleculares y lingüistas-naturalistas. Unos no son mejores que otros, simplemente son distintos. Y también son distintos sus afectos y sus intereses. Para el lingüista-naturalista lo que importan son las lenguas: cómo surgen, cómo cambian y varían sus dialectos, cómo las usan las personas, cómo se pueden dignificar y regular, cómo mueren y cómo se pueden preservar. Para el lingüista-molecular lo importante no son las lenguas, sino de qué están hechas. Interesan los 'individuos' (las gramáticas mentales de las personas) y, sobre todo, sus mecanismos internos, cómo se relacionan con otros componentes de la mente y qué principios o propiedades explican su estructura y su desarrollo. La diferencia entre ambos radica en la diferente naturaleza de sus objetos de estudio. El objeto de estudio del lingüista-naturalista es un constructo social y cultural, externo a la mente y el cerebro del individuo; el objeto de estudio del lingüistamolecular es un objeto natural, es una propiedad, un estado de la mente y del cerebro del individuo.

\section{Lengua-i y lengua-e}

He sugerido que tanto las especies como las lenguas son agrupaciones de individuos semejantes. Así, una especie natural está formada por individuos (por ejemplo, animales) lo suficientemente semejantes como para

1 «The formation of different languages and of distinct species, and the proofs that both have been developed through a gradual process, are curiously the same» (Darwin 1871). La edición revisada de 1874 y las posteriores dicen «curiously parallel». 
procrear otros individuos capaces, a su vez, de reproducirse. Un orangután y una persona se parecen más entre sí que un orangután y una vaca, pero las tres son especies distintas. Sabemos que la mayor semejanza entre un orangután y una persona se debe a que el ancestro común de ambos es mucho más reciente (de hace unos seis millones de años) que el ancestro común de los dos con las vacas (de hace cientos de millones de años).

Por su parte, una especie lingüística, una lengua, está formada por individuos (gramáticas mentales) lo suficientemente similares como para permitir a sus poseedores comunicarse fluidamente. El equivalente lingüístico del organismo natural (por ejemplo, un tigre) es, por tanto, el órgano del lenguaje de cada persona, esto es, aquel estado de su cerebro que le permite hablar con otras personas. El equivalente lingüístico de la especie natural (por ejemplo, la de los tigres) es la agrupación de órganos lingüísticos de ese tipo basada en la mutua inteligibilidad, esto es, la lengua en el uso habitual de la palabra. Y del mismo modo, el español y el francés se parecen más entre sí que el francés y el ruso, pero son dos lenguas distintas. Sabemos que la mayor semejanza entre el español y el francés se debe a que su ancestro común es mucho más reciente (de hace unos 1500 años) que el ancestro que comparten con el ruso (de hace unos 6000 ańos).

En biología no hay confusión entre el organismo y la especie, pero en lingüística la terminología es más confusa, así como las ideas al respecto. Si aceptamos el modelo de comparación esbozado, parecería que la palabra lengua sirve tanto para el equivalente del organismo como para el equivalente de la especie, lo que ha sido - y sigue siendo - fuente de controversia y de graves equívocos en nuestra disciplina.

Una estrategia (en absoluto novedosa) para resolver ese problema es la de proponer convenciones terminológicas para evitar la confusión. Así, aquello que el lector tiene en la cabeza y que le permite entender lo que ahora está leyendo se puede denominar, siguiendo a Chomsky (1985), lengua interna (lengua-i). La lengua-i es el órgano del lenguaje de una persona, su facultad del lenguaje. Así pues, al menos hay tantas lenguas-i como personas, puesto que cada persona (casos patológicos al margen) tiene al menos una lengua-i en su cerebro. Como lo más habitual en nuestra especie (en contra de la creencia occidental) es que las personas hablen más de una lengua, puede decirse con total seguridad que hay muchas más lenguas-i que personas. 
Lo único real desde el punto de vista biolingüístico son esos miles de millones de lenguas-i. Todo lo demás (variedades, dialectos, lenguas, familias, etc.) son (útiles) abstracciones que hacemos agrupando lenguas-i en función de su semejanza o de su origen histórico. Lo mismo sucede en el ámbito biológico: lo que existen son los estados emergentes de la materia que denominamos formas de vida, los organismos (los billones de animales, plantas, hongos, etc., que viven en el planeta), mientras que las variedades, especies, familias, reinos, etc., son (útiles) abstracciones que hacemos basándonos en la semejanza genética y morfológica y en el origen histórico.

Una lengua-i, desde el punto de vista naturalista, es un objeto natural históricamente modificado. $\mathrm{Y}$ eso es lo que son los organismos naturales que se agrupan para formar especies naturales: objetos naturales históricamente modificados. Que el órgano del lenguaje de una persona, su lengua-i, sea un objeto natural implica que no es un objeto netamente social o cultural, lo que no implica que no sea también un objeto histórico. El órgano del lenguaje de una persona que habla francés es distinto al de una persona que habla espańol; los dos comparten (supuestamente) un diseño común que llamamos convencionalmente Gramática Universal, pero se diferencian por sucesos contingentes que solo podemos explicar históricamente: migraciones, cambios divergentes, préstamos y aislamiento produjeron dos objetos naturales distintos (en realidad, millones de ellos, tantos como hablantes de las dos lenguas). Pero es importante subrayar que el hecho de que la lengua-i de un francés y de un español sean históricamente distintas no debe hacernos pensar que se trata de objetos puramente históricos, del mismo modo que un caballo y un búfalo son objetos históricos distintos, pero no son netamente históricos, sino también naturales.

$\mathrm{Al}$ igual que no hay dos personas — ni dos tigres — iguales, tampoco hay dos lenguas-i iguales. Por supuesto, si vemos dos personas y un tigre, enseguida decidimos que, comparadas con el tigre, las dos personas son iguales, haciendo abstracción de sus obvias diferencias. Del mismo modo, si oímos hablar a dos rusos y a un japonés, enseguida decidiremos — aunque no hablemos esas lenguas - que los rusos hablan lo mismo, y que el japonés no. Lo que estamos afirmando entonces es que los dos rusos hablan la misma lengua. Pero aquí ya no estamos hablando de la lengua-i (que es diferente en cada persona), sino de la lengua externa (o lengua-e). 
El término lengua-e ha tenido usos muy variados en la bibliografía (véanse, p. ej., Chomsky 1985, Smith 1999 o Isac y Reiss 2008) y resulta llamativo lo mucho que se ha usado el término si tenemos en cuenta que quien lo acuñó, Chomsky, lo hizo para negar su relevancia. ${ }^{2}$ En general, la corriente generativista considera la lengua-e como un objeto heterogéneo e inconsistente, ya que se define, bien como el conjunto de emisiones lingüísticas de una comunidad, bien como el resultado del uso del lenguaje, bien como una institución social o cultural. ${ }^{3}$ En efecto, tales nociones son irrelevantes para el punto de vista biolingüístico, lo que obviamente no implica que lo sean para aproximaciones sociolingüísticas, de lingüística de corpus, etc.

Sin embargo, hay muchos lingüistas que no aceptarían estas definiciones de lengua-i y de lengua-e, en el sentido de que afirman que lo que realmente existe es la lengua-e, mientras que la lengua-i no es más que una manifestación de la lengua-e en la mente de las personas. Esta postura recuerda claramente a Saussure, para quien la lengua (langue), en oposición al habla (parole), «es social en su esencia e independiente del individuo» (p. 81); «la lengua es la parte social del lenguaje [...] no existe más que en virtud de una especie de contrato establecido entre los miembros de la comunidad» (p. 81). Nótese que Saussure no ignora la existencia de la lengua-i como conocimiento del lenguaje de cada persona, ya que también define la lengua como «un tesoro depositado por la práctica del habla en los sujetos pertenecientes a la misma comunidad" (p. 29), sino que invierte los términos, confiriendo preeminencia ontológica a la lengua-e, siendo las lenguas-i registros parciales de la misma. Así, define la lengua como la suma de lenguas-i: "la lengua existe en la colectividad bajo la forma de una suma de acuñaciones depositadas en cada cerebro», «la suma de las imágenes verbales almacenadas en todos los individuos», «la suma de los tesoros de lengua individuales» (p. 30). ${ }^{5}$

2 «Podemos definir 'lengua-e' de una forma u otra, o de ninguna, puesto que este concepto no desempeña ningún papel en una teoría del lenguaje» (Chomsky 1985 [1989]: 42).

3 Como señala Smith, «si bien es habitual hablar del 'idioma inglés' hablado en distintos continentes y en distintos siglos, una entidad tan dispersa en el espacio y en el tiempo no puede responder a ninguna realidad mental ni psicológica» (1999 [2001]: 203).

4 Citas de Saussure tomadas de Mounin (1968 [1971]), a cuyas páginas se remite.

5 El concepto de langue de Saussure se parece por tanto más a lo que Chomsky (véase Isac y Reiss 2008: 71) denomina lengua-p (por platónica), un constructo ideal al que pueden pertenecer palabras o frases que no necesariamente forman parte de la lengua-i de muchos hablantes de cierta comunidad y que, sin embargo, 'pertenecen' a la lengua-p. 
Pero, aunque relativamente frecuente aún en la lingüística contemporánea, es una manera extraña de pensar desde un punto de vista naturalista. Sería lo mismo que decir que lo que existe realmente es la especie de los tigres, y que los tigres que encontramos en la naturaleza no son sino manifestaciones de la especie de los tigres. Parece más razonable asumir que los individuos (sean lingüísticos u orgánicos) preceden a los grupos que podemos hacer basándonos en sus semejanzas y diferencias.

Esta distinción terminológica nos permite ser más precisos. Así, a la pregunta de cuántas lenguas hay en el mundo, deberíamos responder que depende: si nos preguntan por lenguas-i, tendríamos que responder que hay miles de millones; si nos preguntan por lenguas-e, tendríamos que decir que quizá unos pocos miles (entre cinco y siete mil será la respuesta que hallemos en manuales y catálogos). A la pregunta de qué es una lengua, también tendremos que responder con un depende: si hablamos de lengua-i, entonces tendremos que responder, vagamente, que una lengua-i es un sistema de conocimiento de una persona, un órgano mental, un estado de su cerebro; si hablamos de lengua-e, entonces tendremos que responder que es un conjunto o población de lenguas-i lo suficientemente semejantes entre sí. Cualquier otra definición de lengua-e (como acervo cultural común, institución social, código compartido, etc.) es lícita e interesante en sí misma, pero ajena a la aproximación biolingüística. Ese es el ámbito de la sociolingüística, usando el término en sentido amplio y meramente contrastivo.

\section{Delimitando las lenguas-e}

Como hemos visto, cuando nos preguntamos qué es una lengua (por ejemplo, qué es el francés), desde el punto de vista biolingüístico nos tenemos que limitar a responder que es una agrupación de lenguas-i suficientemente semejantes. Esta respuesta, aun siendo la mejor que podemos dar, plantea no pocos problemas, especialmente si se quiere fundamentar la investigación del lenguaje en alguna noción de lengua-e y no en la lengua-i. Uno de ellos es qué cuenta como suficientemente semejante, esto es, qué grado de semejanza hace falta para decidir si dos lenguas-i forman parte de la misma lengua-e o no. 
Ya no debería resultar curioso observar que el mismo problema se le plantea al naturalista. ¿Cómo decide si dos organismos que son muy parecidos pero tienen ciertas diferencias pertenecen a dos variedades de la misma especie o a dos especies distintas? El criterio habitual en biología se basa en la capacidad reproductiva fértil. Así, un mastín y un chiguagua son animales relativamente distintos, pero los agrupamos en la misma especie (Canis canis) porque —al menos en teoría - pueden procrear entre ellos otros perros que, a su vez, pueden seguir procreando perros. Un toro y un búfalo son animales relativamente semejantes, pero pertenecen a distintas especies porque no pueden procrear entre ellos. En general, es un criterio claro que se centra en el aislamiento reproductivo (no en vano las especies se definen como comunidades reproductivas), pero eso no significa que esté libre de zonas borrosas. Es bien conocido el caso de las llamadas especies anillo. Una especie anillo es una serie conectada de poblaciones vecinas cada una de las cuales puede cruzarse con las adyacentes. Sin embargo, entre poblaciones distantes en los extremos se han acumulado tantas diferencias que ya no pueden cruzarse entre sí. En todo caso, aún es posible un cierto flujo de genes entre las poblaciones, a través de las 'fronteras fértiles'. El caso más conocido es el de ciertas gaviotas en el ártico (Larus). El problema, claro está, tiene que ver con el hecho biológico de que la reproducción fértil no es una relación transitiva. Si A puede cruzarse con $\mathrm{B}$ diremos que A y B forman parte de la misma especie. Si B puede cruzarse con C, diremos que $\mathrm{B}$ y $\mathrm{C}$ pertenecen a la misma especie, pero entonces $\mathrm{A}$ y $\mathrm{C}$, que no pueden cruzarse entre sí, tienen que ser a la vez la misma especie y una especie distinta.

Claro que a los lingüistas nada de esto debería extrañarles. Ya en el siglo XIX se hablaba de continuos dialectales y Bloomfield (1933) los definió precisamente como áreas dialectales entre cuyos extremos se perdía la intercompresión. ${ }^{6}$

Si el criterio de delimitación de una especie natural es difuso y relativamente arbitrario, otro tanto sucede con las lenguas, lo que está agravado además por la naturaleza abstracta y relativamente inaccesible de los indi-

6 "The difference from place to place is small, but, as one travels in any one direction, the differences accumulate, until speakers, say from opposite ends of the country, cannot understand each other, although there is not a sharp line of linguistic demarcation between the places where they live» (Bloomfield 1933: 51). 
viduos lingüísticos, esto es, de las lenguas-i. Tanto los profanos como no pocos lingüistas creen que un conocimiento relativamente profundo de la estructura y propiedades de las lenguas puede ser de utilidad a la hora de determinar si dos lenguas-i cualesquiera son ejemplares de la misma lengua o de dos lenguas distintas. Pero no es así. Esa creencia es errónea no porque no tengamos suficiente información sobre la estructura del lenguaje (que no la tenemos), sino porque se basa asimismo en otra creencia falsa, la de que las lenguas-e tienen una existencia propia más allá de las lenguas-i que hay dentro de las personas. Pareciera como si las lenguas-e tuvieran existencia 'ahí fuera' y que, dadas dos muestras de dos lenguas-i concretas, nuestra tarea sería la de decidir si pertenecen a una u otra lengua-e. Claro que hacemos cosas así a menudo, pero solo en apariencia: en realidad lo que hacemos es intentar determinar, basándonos en las semejanzas y diferencias, a qué tipos de lenguas-i se parecen más dichas emisiones.

Nótese que no se trata de identidad o de pertenencia en sentido matemático, sino de mayor o menor grado de semejanza. La cuestión crucial es entonces cómo determinamos qué grado de semejanza cuenta como suficiente, esto es, cómo determinamos en qué aspectos y en qué grado deben parecerse dos lenguas-i para que las consideremos variantes de la misma lengua-e. Aunque suele resultar frustrante para el profano, la única respuesta que la lingüística puede ofrecer es que dicho criterio se basa en la mutua inteligibilidad, esto es, en si dadas dos lenguas-i cualesquiera, sus respectivos usuarios pueden entenderse mutuamente. ${ }^{7}$ El problema es que la mutua inteligibilidad también es una cuestión de grados (al fin y al cabo, se basa, como la capacidad de reproducción fértil, en un umbral de semejanza) y, por tanto, también tendremos que imponer al final un criterio arbitrario para decidir si la hay o no. Esto es así simplemente porque las lenguas-i no son ejemplares (tokens) de tipos (types) previamente definidos. Muchas personas piensan que las lenguas-i son como los objetos matemáticos, de manera que dados varios ejemplares, podemos determinar objeti-

7 Este es el criterio que Dixon (1997) denomina criterio lingüístico. Todos los demás criterios que empleamos son, también en términos de Dixon, criterios políticos. Así, por poner ejemplos relativamente claros, según el criterio lingüístico el serbio y el croata son la misma lengua, pero según criterios políticos son dos lenguas diferentes. Hace no muchos años el serbo-croata se consideraba una única lengua también desde el punto de vista del criterio político, lo que pone de manifiesto su carácter arbitrario. 
vamente su identidad tipológica. Si nos dan un conjunto cualquiera de números naturales (sean 3, 5, 34 y 35), podemos demostrar cuáles pertenecen al conjunto de los número pares y cuáles al conjunto de los números impares, o cuáles son números primos y cuáles no lo son. Lo importante es que en esa operación no entran cálculos de grado de semejanza: no hay un número un poco menos par que el 34 pero menos impar que el 35, o uno un poco más o menos primo que el 5 .

Imaginemos que en lugar de un conjunto de números nos ofrecen un conjunto de animales (por ejemplo, dos ratones, una rata y un gato) y nos piden que los agrupemos por especies. Obviamente, nunca podremos ofrecer una demostración matemática de a qué clase pertenecen ni de que los dos ratones pertenecen a la misma especie. En el mejor de los casos podríamos compararlos gen a gen. Si hiciéramos eso, en un momento dado estaríamos en disposición de decir que los dos ratones comparten algunos genes más entre sí que con el resto de organismos, por lo que decidiríamos que pertenecen a la misma especie, de la que están excluidos los demás. Tendríamos razón, pero no como en el caso de los números, sino simplemente porque hemos establecido que el grado de semejanza entre los dos ratones es suficientemente alto como para considerarlos, arbitrariamente, de la misma clase. Nótese que el que afirmemos que el criterio es arbitrario no significa que sea gratuito o que no sea relevante. Lo único que eso significa es que previamente hemos establecido, basándonos en criterios externos al propio objeto en cuestión, cuál es el límite que consideraremos suficiente. La tarea de decidir si dos lenguas-i pertenecen a la misma lengua-e es, pues, más parecida a la de los ratones que a la de los números, una tarea basada en consideraciones externas (políticas, sociales, culturales) a los propios objetos (las lenguas-i).

\section{Separando la biolingüística de la sociolingüística}

Lo que esto significa entonces es que la realidad que subyace es la de una continuidad. A pesar de las apariencias, esto es lo real, tanto en biología como en lingüística. Pero si lo que existe como objeto básico de la investigación lingüística es una continuidad de lenguas-i, entonces no es lícito construir una teoría lingüística bajo el supuesto de que el objeto de estudio de partida es un conjunto discreto de lenguas-e. Mi opinión es que es esta 
maniobra errónea lo que motiva la concepción de las lenguas humanas como objetos externos a la mente y todo lo que dicha concepción implica en relación con la valoración del grado de diversidad de las lenguas, la concepción de cómo se desarrollan en el individuo, e incluso el tipo de disciplina que debe ser la lingüística. Así, por ejemplo, Evans y Levinson (2009) presentan un programa de investigación basado en dicha concepción y orientado precisamente a combatir la idea de los universales del lenguaje, considerados un mito. Pero si la realidad subyacente es una continuidad de lenguas-i, se hace más fácil aceptar que todas las lenguas-i son variaciones superficiales de un mismo sistema de conocimiento, al igual que, como ha sugerido el bioquímico Michael Sherman (2007), desde un punto de vista lo suficientemente abstracto, solo existiría un organismo pluricelular con patrones superficiales de variación.

Esta reflexión no busca trivializar ni, por supuesto, descartar la noción (o nociones) de lengua-e como un concepto central de la lingüística, sino señalar lo incoherente y grave que sería para la teoría lingüística dar preferencia ontológica a la lengua-e (en cualquiera de sus definiciones) sobre la lengua-i, algo que, sin embargo, de manera más o menos explícita caracteriza a parte de la lingüística actual.

Pero si se parte de la lengua-e como el objeto básico (considerando, d̀ la Saussure, que las lenguas-i son manifestaciones parciales de la lengua-e en la mente de los hablantes), entonces emerge una concepción antinaturalista del lenguaje, una concepción en la que las lenguas naturales son concebidas como objetos socioculturales y no como objetos naturales. Si perdemos el punto de vista naturalista y hacemos partir nuestra investigación del nivel superior, esto es, el de la lengua-e, nuestras conclusiones sobre la propia naturaleza del lenguaje humano acabarán irremisiblemente distorsionadas, dado que las lenguas-e se definen frente al resto de lenguase usando un criterio diferencial lingüísticamente arbitrario.

$\mathrm{Si}$, por el contrario, nuestro compromiso último es la lengua-i (aunque por razones prácticas sigamos hablando de lenguas-e), seremos más capaces de soslayar la evidente diversidad que el cambio en el tiempo produce en las agrupaciones de lenguas-i y estaremos en mejor disposición de abordar el estudio del lenguaje humano como una propiedad de la especie, el único objetivo científico lícito desde el punto de vista biolingüístico. 
Si se adopta el punto de vista biolingüístico, la relación entre el lenguaje y las lenguas es proporcional a la relación entre la vida y las formas vivas, los organismos. Por supuesto que lo que encontramos en el mundo son los organismos y no la vida en sí. La vida solo existe como organismos, y es bien cierto que estos son notoriamente diversos y que se agrupan en especies, pero ello no implica negar que la vida exista (por ejemplo, en contraste con el mundo inorgánico), ni implica que consideremos secundario buscar qué propiedades comunes la definen y la explican. De hecho, ese es el objetivo central de la biología como ciencia. No hay razones para pensar que no deba ser del mismo modo en lingüística.

\section{Referencias}

Bloomfield, L. (1933): Language, Londres, George Allen \& Unwin.

Сномкку, N. (1985): Knowledge of Language: Its Nature, Origin and Use, Nueva York, Praeger (citado por la versión espańola: El conocimiento del lenguaje, Madrid, Alianza, 1989).

Darwin, C. (1871): The Descent of Man and Selection in Relation to Sex (citado por la reproducción accesible en On Line Literature Library: www.literature. org).

Dixon, R. M. W. (1997): The Rise and Fall of Languages, Cambridge, Cambridge University Press.

Evans, N. y S. C. Levinson (2009): «The Myth of Language Universals: Language diversity and its importance for cognitive science», Behavioral and Brain Sciences, 32: 429-448.

Isac, D. y C. ReIss (2008): I-Language, Oxford, Oxford University Press.

Mounin, G. (1968): Saussure ou le structuralisme sans le savoir, París, Seghers (citado por la versión española: Saussure: presentación y textos, Madrid, Anagrama, 1971).

Sherman, M. (2007): «Universal genome in the origin of metazoa: thoughts about evolution", Cell Cycle, 6/15: 1873-1877.

Sмітн, N. (1999): Chomsky: Ideas and Ideals, Cambridge, Cambridge University Press (citado por la versión española: Chomsky: Ideas e ideales, Madrid, Cambridge University Press, 2001). 


\title{
EL NACIMIENTO DE LAS ESCRITURAS Y LOS ORÍGENES DE LA REFLEXIÓN LINGÜÍSTICA
}

\author{
Jesús Tusón Valls \\ (Universidad de Barcelona)
}

\section{Primeras consideraciones}

No tardará demasiado en cumplirse medio siglo desde que John Lyons calificase de "falacia clásica» el tópico consistente en considerar que la escritura representaba un modelo de pureza indiscutido y, por lo tanto, la materia objeto de estudio para las investigaciones sobre el lenguaje y las lenguas. Pero nuestros últimos decenios de práctica lingüística han dejado también muy claro, por fin, que las antiguas preferencias academicistas por la escritura no habían hecho sino desviar la atención del objeto primario de estudio, desplazando la mirada desde su centro esencial, la dimensión oral (o, en su caso, signada), hasta una especie de sucedáneo de más que dudosa calidad. Hoy, pues, queda claro para la mayoría de los lingüistas que la escritura, además de ser un artificio secundario, es también pobre y, en consecuencia, solo cabría considerarla como vía de acceso para la investigación si nos ocupásemos de las llamadas «lenguas muertas».

Pese a todo, la losa de la escritura sigue lastrando algunas investigaciones, especialmente las tipológicas, como ha advertido en diversas ocasiones el profesor Juan Carlos Moreno al abordar de manera contundente la crítica de las clasificaciones habituales que nos hablan de lenguas aislantes, 
aglutinantes, flexivas y polisintéticas; tipos claramente condicionados por unas tradiciones de escritura en las que se separan las problemáticas «palabras». Si alguien quiere asomarse a un ejemplo eminente, puede entretenerse considerando la "palabra más larga» aducida por David Crystal (en su Enciclopedia, página 115), que se traduce por 'La estación de Mawddach y sus dientes de dragón [unas estructuras para la defensa] en la carretera del norte de Panrhyn, sobre la playa dorada de la bahía de Cardigan'; una palabra realmente polisinténtica (o tal vez muy aglutinante)... cuya longitud resultaría apliamente superada si ahora mismo el autor del presente artículo tuviese la ocurrencia insana de prescindir, de golpe y porrazo, de la amable costumbre de separar las palabras escritas. De repente, nos encontraríamos no ya con una lengua caracterizada por tener palabras-oración; sino por ofrecernos generosamente palabras-artículo.

Por otra parte, conviene no perder de vista que la escritura, cuyas muestras más antiguas apenas rebasan los cinco mil años, es un fenómeno muy reciente; y más si tenemos en cuenta que los paleoantropólogos, en coincidencia con los especialistas en genética de las poblaciones, han establecido que el Homo sapiens anatómicamente moderno hizo su aparición estelar hace unos doscientos mil años. Lo que nos indica que los humanos, ya plenamente evolucionados y con un cerebro de $1400 \mathrm{~cm}^{3}$, hicimos la mayor parte de nuestro recorrido verbal sin necesidad de la escritura (y, además, sin contar con que la abrumadora mayoría de la humanidad ha llegado a la condición de alfabetizada en tiempos muy recientes). Un argumento más, y de peso, para situar la escritura en un lugar claramente secundario en lo que se refiere al desarrollo de la facultad del lenguaje. Sin embargo, no estará de más reconocer que la actividad escriptural es realmente útil para la humanidad allá donde resulta indispensable; es decir, en las circunstancias de gran complejidad administrativa en las que vivimos algunos pueblos; por lo menos desde la revolución neolítica, con la consiguiente sedentarización y con la formación de unas primeras ciudades que no se podían gestionar de memoria y que requerían de la ayuda indispensable de registros escritos de todo tipo.

Sirvan estas observaciones preliminares para proclamar, una vez más, que la dimensión primaria, esencial y más general del lenguaje es la oralidad. Y así ha quedado establecido en el ámbito profesional de la Lingüística. Pese a todo, no parece ocioso plantearse también, en su justa (y, acaso, 
modesta) medida, si una consideración de los diferentes tipos históricos de escritura, al menos en sus momentos fundacionales, podría aportarnos algunos indicios útiles sobre la reflexión lingüística en la antigüedad, cosa que nos permitiría remitirnos a etapas bastante anteriores a los hitos que suelen marcar los inicios de la historia de la Lingüística en la India o en Grecia.

\section{El ingenio de los profesionales de la escritura}

Simplificando un poco los planteamientos preliminares, parece ser que la escritura, como fijación del habla, solo se ha producido de tres maneras, si tenemos en cuenta las primeras muestras y si las relacionamos con algunas características de las lenguas: o bien la escritura es representación «de la palabra», o bien es representación «de la sílaba» o es, finalmente, representación «de las unidades sonoras mínimas de la lengua». Dicho lo cual no es ocioso que nos preguntemos por qué no han sido posibles históricamente ni la escritura de las unidades morfológicas (con signos globales, específicos y arbitrarios, para las formas de "género», «número», «diminutivo», «comparación», «relación», etc., asociadas a los morfemas léxicos), ni que tampoco se haya dado el caso de la existencia de signos que valgan para marcar las estructuras sintácticas (por ejemplo, con grafias independientes para "pasiva», «agente», «objeto», «modo», etc.). La asunción por la escritura de los niveles morfológico y sintáctico, claro está, hubiese requerido un análisis avanzado de la gramática de una lengua; y los tiempos iniciales de esta técnica (y sus funciones prácticas) no parece que hubiesen podido incluir reflexiones de esta índole. Así pues, los tipos de escritura, lógica y culturalmente posibles, han sido la léxica, la silábica y la fonológica (frecuentemente combinadas, eso sí, en algunas culturas que practicaron y practican sistemas híbridos). Lo cierto es, por otra parte, que especialmente los dos últimos tipos, al representar segmentos no significativos de las lenguas, pueden dar cuenta de toda la gama de realidades del sistema lingüístico, también de las estructuras morfológicas y de las sintácticas: por ejemplo, con una escritura alfabética podemos escribir camión (un elemento léxico), camionero (un elemento léxico al que se añaden un morfema de "relación» y otro de "género»), y también podemos dar cuenta de valores sintácticos como de (encabezador de "complemento»), pues (indicador de 
"consecuencia»), ágilmente (un elemento de «modo» incorporado al morfema léxico), etc. Veamos ahora qué pueden dar de sí estos tres tipos de escritura y qué reflexiones podrían asociarse a sus diferentes nacimientos.

La escritura léxica apareció de manera independiente en tres ámbitos geográficos distintos: Mesopotamia, China y Mesoamérica. En estos tres territorios, la escritura de la palabra surgió de forma muy natural gracias a los pictogramas; es decir, a unas figuras realistas que se vinculaban con las cosas y también con las palabras que las designaban. Lo interesante de este primer paso es que los pictogramas, como norma general, se convirtieron en logogramas (antes llamados, impropiamente, «ideogramas») en virtud de un proceso de desfiguración producido, sin duda, por la necesidad de escribir más rápidamente en menos tiempo, con lo que se introdujo una especie de «cursividad» que simplificó el número de trazos de cada signo (y más si no olvidamos la esquematización que se produjo en Mesopotamia con la introducción de la técnica cuneiforme). No cuesta nada imaginar que, como consecuencia de esta desfiguración, los escribas vieron allanado el camino para que también pudiesen recibir un signo gráfico todas aquellas realidades que no podían ser dibujadas: a partir de este proceso, palabras referidas a conceptos abstractos como la «bondad» o la «maldad», la «inteligencia» o la «armonía», pudieron ser acogidas por la escritura y representadas arbitrariamente con la máxima facilidad, si así lo acordaban los escribas. Este paso ha de ser considerado como auténticamente revolucionario porque supuso que las figuras visuales dejaban de sugerir los objetos (ya no los representaban icónicamente) y, necesariamente, había que vincularlas con las palabras; es decir, con la lengua. Por primera vez, pues, con los logogramas la escritura pasa a depender exclusivamente de la estructura lingüística (y no directamente de la referencia).

Por su parte, los sistemas silábicos son una segunda revolución en la historia de la escritura; y, aunque no tengamos constancia testimonial de ello, no cuesta mucho imaginar que un escriba, abrumado por la necesidad de usar tantísimos signos como los que requiere una escritura vinculada a la palabra, descubrió que en la lengua existían unidades recurrentes (las sílabas) en un número considerablemente inferior al de las palabras y al de sus correspondientes logogramas. Conviene, además, no perder de vista que, en la Antigüedad, los escribas eran una casta cerrada y privile- 
giada, dedicada de por vida a un oficio muy apreciado y absolutamente necesario para la correcta administración de la cosa pública. Así pues, no se puede descartar que en los scriptoria y en las escuelas de escribas fuese habitual la solución de problemas relativos al oficio, para hacerlo más llevadero y de ejecución más rápida. El descubrimiento del silabario, además, se suele atribuir en las historias de la escritura, de forma natural, a la puesta en juego del principio de rebus (o del jeroglífico) que permite dividir una palabra en segmentos menores, cada uno de los cuales se corresponde, a su vez, con otra palabra. Así, por poner un ejemplo, antes del descubrimiento del silabario, col sería representado por una figura, mar por otra y colmar por una tercera; con un silabario, sin embargo, colmar puede escribirse con los signos de col y de mar, y así en todos los demás casos. De manera que el principio de rebus podríamos formularlo así: «el signo que hasta ahora representa a una palabra ( $\mathrm{col}$, mar, etc.) pasará a usarse para escribir esa secuencia de sonidos allá donde se encuentre». La introducción del principio silábico supuso un salto decisivo desde el punto de vista de la economía escritural, porque ahora solamente eran necesarios muy pocos signos para llevar a cabo el trabajo (por ejemplo, los silabarios antiguos solían tener entre seis y ocho docenas de figuras). Además, la gran economía del silabario y, sobre todo, la vinculación de la escritura con el nivel sonoro de la lengua vino a prefigurar el último estadio de muchas escrituras: el alfabeto.

Las escrituras fonológicas, o alfabéticas, son (al menos si solamente nos atenemos a la cantidad) sistemas sumamente minimalistas, que presentan ventajas obvias desde el punto de vista de la transmisión y de la adquisición; y esto explicaría el triunfo de los alfabetos entre muchísimos pueblos y, muy singularmente, en las riberas del Mediterráneo antiguo. Y si el silabario se organizó, como hemos visto, sobre el principio de rebus, el alfabeto únicamente pudo obtenerse a partir del principio de la acrofonía. Este principio diría aproximadamente: «el signo que hasta ahora se usa para representar una palabra (o, en su caso, una sílaba) quedará reservado desde este momento para escribir sólo el sonido inicial de la palabra (o de la sílaba), allá donde se encuentre». Es, exactamente, el artificio que ponemos en juego cuando tenemos que deletrear un apellido poco usual y decimos: T de Tauste, U de Uncastillo, S de Sobradiel, O de Orcajo y N de Nonaspe, costumbre que es posible a partir de una instrucción como la siguiente: «escribe A donde encuentres el sonido inicial de árbol, B para 
el de boca, C para el de casa, etc.». Con este recurso, los antiguos fenicios establecieron la escritura y orden alfabéticos: A de aleph («buey»), B de beth ("casa»), C de gimel ("camello»), D de daleth ("puerta»), etc. (obviamente con las grafías correspondientes a las primeras etapas), configurando así una lista que, con pocas modificaciones, ha llegado hasta nuestros diversos alfabetos. El descubrimiento del principio alfabético redujo aún más el número de signos necesarios para la escritura: entre veinte y treinta, en la mayoría de los casos.

Este breve recorrido tipológico ha de ser cerrado con dos observaciones. La primera es que el paso de una escritura a otra revela hasta qué punto se aguza el ingenio humano cuando es imprescindible dar solidez gráfica al habla huidiza y se inventan sistemas cada vez más prácticos, más fáciles de adquirir y también se elaboran técnicas para ejecutar la escritura con mayor rapidez. La segunda observación tiene que ver con un cierto escepticismo ante afirmaciones apresuradas sobre lo sagaces que fueron algunos pueblos del Oriente Próximo que, como a veces se ha sugerido, casi descubrieron la fonología. Vistas las cosas en su contexto puramente práctico, todo indica que los antiguos escribas lo único que, al parecer, hicieron fue resolver problemas cotidianos para aligerar la dureza de su oficio; y no hay pruebas de que los cambios en los sistemas de escritura pudieran haber sido el fruto de reflexiones sobre los aspectos estructurales de las lenguas. Es mucho más verosímil (ante la falta de documentos explícitos que sugieran lo contrario) que simplemente tratasen de reducir el número de símbolos apoyándose en las recurrencias típicas de las lenguas. Desde esta perspectiva, ahora sí, podríamos decir que los profesionales de las diversas escrituras, al abandonar la pictografía y la logografia, descubrieron que en una lengua era posible, a partir de muy pocas unidades, fijar por escrito cualquier texto práctico y, por extensión, las elaboraciones infinitas del pensamiento.

\section{Una revolución semiótica}

Y es este el momento ideal para orientar la exposición hacia territorios vecinos a los lingüísticos. Porque, si bien los inicios de las diferentes escrituras difícilmente pueden ser asociados a un nacimiento 
remoto de la reflexión lingüística, sí que es justo reconocer que la aparición de las escrituras debería constituir por derecho propio un hito (todavía no marcado, según parece) en el campo de la semiótica porque, como veremos, la escritura deriva de la capacidad netamente sapiens para generar imágenes y símbolos; es decir, objetos que, desde tiempos muy antiguos, usamos los humanos para referirnos a otras entidades. En este marco semiótico, la escritura sería un modo muy especial de suplantar la realidad verbal gracias a un modo decididamente ingenioso de jugar con algunas transferencias intersensoriales realmente problemáticas.

Porque la escritura ha de ser considerada forzosamente como un caso singular de representación (o transferencia semiótica) intersensorial teóricamente imposible. Digámoslo bien claro: a nadie se le ocurriría "oler el concierto para piano número 2 de Rachmaninov», o "escuchar Las Meninas», o "acariciar la rugosidad de un perfume». En estos tres casos se da una condición muy especial: la lengua nos permite elaborar, eso sí, las expresiones correspondientes: unas figuras retóricas llamadas sinestesias, con las que ponemos en relación dos entradas sensoriales diferentes (olfato-oído en la primera; oído-vista en la segunda y tacto-olfato en la tercera). Pero, aunque se trate de expresiones posibles, como demuestra el hecho de que las hayamos producido, no hay manera humana de realizar las tres acciones descritas, ni siquiera de concebirlas realmente. Sin embargo, en la escritura el flujo verbal, que es vocal y auditivo, queda efectivamente fijado por unas grafías que son captadas a través de la vista. Por eso, el gran problema que hay que tratar de resolver es el de aquellas sinestesias, imposibles en la práctica, que implican una transferencia desde el sentido auditivo al visual. Porque «ver las palabras» tendría que ser tan quimérico como «oler un concierto para piano». Veámoslo paso a paso y con la ayuda de unos cuadros en los que se expresan (entre paréntesis) los dominios sensoriales implicados en cada caso.

Una transferencia semiótica es posible si no saltamos desde un sentido a otro $\mathrm{y}$, por lo tanto, si no rebasamos el ámbito de las representaciones intrasensoriales. En esta situación, una manzana real puede ser representada por medio de la pintura de una manzana; o bien el canto real de un pájaro puede ser imitado con un instrumento musical: 
Cuadro 1. Transferencia intrasensorial

una manzana real $\rightarrow$ la pintura de una manzana

(visual) (visual)

el canto real de un pájaro $\rightarrow$ la imitación del canto

(sonoro) (sonoro)

Como puede observarse fácilmente, de visual a visual hay una línea continua de puntos con la que se pretende simbolizar la viabilidad de la transferencia y, de hecho, reconocemos en la pintura el referente implicado, de manera que la pintura será aceptada como representación del objeto real. Sin embargo, el panorama es muy distinto en el cuadro siguiente:

Cuadro 2. Transferencia intersensorial

\begin{tabular}{|c|}
\hline $\begin{array}{c}\text { una manzana real } \rightarrow \text { representación con sonidos } \\
\quad(\text { visual) } \ldots \ldots \ldots . . . . . \ldots \ldots \ldots . . .(\text { sonoro })\end{array}$ \\
\hline $\begin{array}{l}\text { eanto real de un pájaro } \rightarrow \text { representación pictórica } \\
\quad(\text { sonoro })\end{array}$ \\
\hline
\end{tabular}

En esta otra situación se pretendía obtener la representación de un producto visual (la manzana) por medio de sonidos (o también de un hecho auditivo, el canto de un pájaro en el segundo ejemplo, por medio de una pintura). Y, como vemos, la línea de puntos ha quedado interrumpida porque esta transferencia es imposible: no hay manera humana de conseguir una representación semejante. Justamente, este parece ser el caso de la escritura:

Cuadro 3. La transferencia de la escritura

el flujo real del habla $\rightarrow$ la representación gráfica

(sonoro) (visual)

Ahora tenemos una situación que, en principio, es del todo análoga a la del cuadro anterior. Se trataría, pues, de desplazarse desde el dominio sonoro al visual; es decir, a la representación gráfica de las unidades sonoras del habla. Para entender mejor este tránsito, casi sería forzoso volver al pasado y borrar de nuestra mente cualquier noción y ejemplo de escritura. Así pues, 
imaginemos por un momento que nuestro mundo, embrionariamente neolítico, se ha empezado a complicar; que nuestra capacidad para el recuerdo es limitada y que no hay alternativa: nos es forzoso obtener un método para dar durabilidad a los productos del habla. Y observemos que, en el cuadro inmediatamente anterior, la línea de puntos ha quedado interrumpida no por unas barras infranqueables, sino por unos interrogantes: los signos que representan el problema cuya solución ha de venir por fuerza, porque la transferencia semiótica implicada por la escritura es, volvamos ya a la realidad, un hecho incuestionable, pese a su incongruencia sinestésica. Trataremos, pues, de enfocar la solución, paso a paso, volviendo al principio:

Cuadro 4. Objetos e iconos

\begin{tabular}{|c|c|c|}
\hline $\begin{array}{l}\text { SISTEMA 'A': de los } \\
\text { vehículos reales como } \\
\text { referentes }\end{array}$ & $\rightarrow$ & $\begin{array}{l}\text { SISTEMA 'B': de los } \\
\text { iconos como signos }\end{array}$ \\
\hline 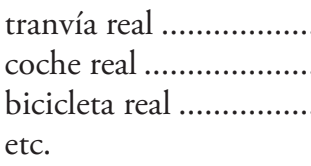 & .... & $\begin{array}{l}\text { dibujo de un tranvía } \\
\text { dibujo de un coche } \\
\text { dibujo de una bicicleta } \\
\text { etc. }\end{array}$ \\
\hline
\end{tabular}

Ahora hemos vuelto a la situación del cuadro primero que, en la historia de la escritura, habrá que asociar con la etapa pictogramática: de momento, nos mantenemos dentro de un mismo dominio, el visual, y convenimos en que el dibujo de un vehículo nos remite al referente. Demos ahora, por lo tanto, un paso más en la línea de la desfiguración logogramática a que antes nos hemos referido, y entremos en el dominio simbólico a través del uso de un sistema arbitrario (y, por lo tanto, no icónico) que solo podrá funcionar si establecemos una convención:

Cuadro 5. Objetos reales y convenciones gráficas

\begin{tabular}{|c|c|c|}
\hline $\begin{array}{l}\text { SISTEMA 'A': } \\
\text { referentes reales }\end{array}$ & $\rightarrow$ & $\begin{array}{l}\text { SISTEMA 'B': } \\
\text { signos convencionales }\end{array}$ \\
\hline 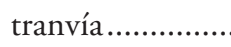 & ....... & $X$ \\
\hline coche & ....... & Y \\
\hline bicicleta................ & ....... & Z \\
\hline
\end{tabular}


Aquí hemos substituido los iconos por una serie de símbolos que son el resultado de una convención. Así pues, cuando nos queramos referir a una bicicleta lo haremos con una Z; y con los correspondientes signos en los otros casos. Pero todavía no hemos resuelto el problema porque, con iconos (cuadro 4) o con símbolos (cuadro 5), seguimos aludiendo a los referentes visuales con elementos también visuales; y nuestro problema pendiente sigue siendo la transferencia intersensorial.

La solución la tenemos muy cerca y nos la brinda el propio lenguaje que, como ya sabemos, es un sistema convencional de referencia gracias al cual aludimos a la realidad, independientemente de sus adscripciones sensoriales concretas, por medio de los símbolos auditivos que son producidos por los órganos del habla. Y todo se resuelve de la manera siguiente:

Cuadro 6. Objetos reales y convenciones lingüisticas

\begin{tabular}{lll}
\hline $\begin{array}{l}\text { SISTEMA 'A': } \\
\text { referentes reales }\end{array}$ & $\rightarrow$ & $\begin{array}{l}\text { SISTEMA 'B': } \\
\text { convenciones lingüísticas }\end{array}$ \\
tranvía (objeto).................................... & $\begin{array}{l}\text { tranvía (palabra) } \\
\text { (visual) }\end{array}$ \\
\hline
\end{tabular}

Ahora el panorama ha cambiado de forma radical, porque los sapiens tenemos incorporado, de forma natural, propia y exclusiva de nuestra especie, un mecanismo de transferencia intersensorial que nos permite aludir a la realidad (a los objetos de la realidad, a sus cualidades, a los acontecimientos del mundo y a todo tipo de relaciones como, por ejemplo, las causas, las consecuencias, las finalidades, etc.) por medio de símbolos sonoros que no proceden de la realidad externa, sino de la mente humana lingüística; y que se ejecutan gracias al complejo aparato vocal. Estos símbolos son el resultado de puras convenciones mentales: por poner algunos ejemplos, la palabra agua ni moja, ni apaga la sed; la palabra fuego ni quema, ni calienta; o la marca de relación causal porque no depende de la voluntad de la naturaleza, sino que solamente es la expresión de una conexión que nuestra mente establece entre dos acontecimientos: La carretera está cortada porque se ha producido un desprendimiento en la montaña. No hay nada en porque que derive de los hechos de la realidad: es una pura convención que nos permite marcar una relación mental, típicamente sapiens, entre dos sucesos por medio de una etiqueta sonora. 
Solo nos resta el último paso, guiados por la independencia sensorial del lenguaje, que se concreta en un último cuadro, ahora ya con tres estadios:

Cuadro 7. Una relación ternaria

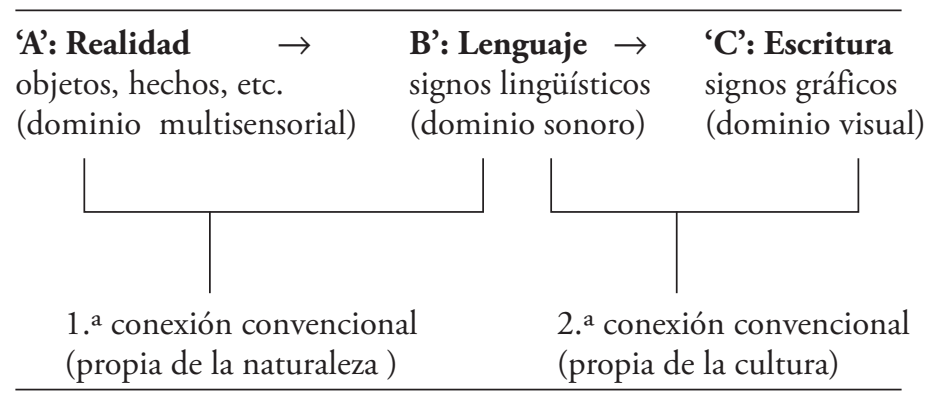

La consecuencia de este punto de vista es la siguiente: el propio lenguaje es un sistema convencional de transferencia intersensorial $(\mathrm{A} \rightarrow \mathrm{B})$ que se constituye en modelo para otros tipos de transferencia, también convencional e intersensorial. Así, es posible el paso $\mathrm{B} \rightarrow \mathrm{C}$ (el paso fundacional de la escritura) que, una vez ejecutado, permite tantos pasos como por convención establezcamos: $\mathrm{C} \rightarrow \mathrm{D}$ si se trata de transitar, ahora, del dominio visual al táctil, como sucede con la escritura Braille; o D $\rightarrow$ B si se convierte esta escritura táctil en registro sonoro. Es, pues, la condición sapiens la que incluye la potencialidad de la escritura, y son algunas circunstancias apremiantes, como la organización de las sociedades complejas desde el neolítico hasta nuestros días, las que determinarán que la escritura se realice efectivamente gracias a la capacidad humana para elaborar símbolos de símbolos. Y símbolos de símbolos de símbolos.

\section{Referencias}

André-Leicknam, G. y Ch. Ziegler (1982): Naissance de l'écriture, París, Éditions de la Réunion des musées nationaux de la France.

Gaur, A. (1987): A History of Writing, Londres, The British Library.

Hooker, T. S. (ed.) (1990): Reading the Past, Londres, British Museum Publications.

Mangel, A. (1996): A History of Reading, Toronto, Knopf Canada. 
Moreno Cabrera, J. C. (2003): «Síntesis y análisis en las lenguas. Crítica de la tipología morfológica clásica y de algunas de sus aplicaciones sincrónicas y diacrónicas», Estudios de Lingüistica de la Universidad de Alicante, 17 (2003): 465-504.

- (2005): Las lenguas y sus escrituras. Tipología, evolución e ideología, Madrid, Síntesis (cap. 1).

Ong, W. J. (1982): Orality and Literacy. The Technologizing of the Word, Londres, Methuen and Co.

Sampson, G. (1985): Writing Systems, Londres, Hutchinson.

Tuson, J. (2007): «Writing: The Story of a Cognitive Revolution», en Eva Teubal, Julie Dockrell y Liliana Tolchinsky (eds.), Notational Knowledge. Developmental and Historical Perspectives, Róterdam, Sense Publishers: 65-78. 


\title{
"EL MÓN ÉS UNA AL·LEGORIA». NOMBRAR LO METALINGÜÍSTICO EN LA POESÍA DE PERE GIMFERRER*
}

\author{
TÚA BLESA \\ (Universidad de Zaragoza)
}

Como cualquier otro campo léxico, también el de lo lingüístico, donde queda incluido todo lo relativo a lo literario - lo que es un argumento para pensar los estudios literarios dentro de la lingüística, una lingüística que atendiera a la literatura y, entonces, más ambiciosa, más rica-, también el conjunto de los términos de lo lingüístico, digo, se hace presente en los textos literarios. Sin embargo, y pese a lo dicho, ese conjunto verbal que remite al lenguaje y la literatura no es como cualquier otro campo léxico. $\mathrm{Al}$ ser lo literario una textualidad, palabras como "decir» o "poema», etc., están apuntando no solo a aquello que nombran, sino que por ese ser lingüístico lo nombrado se refieren de manera directa o indirecta al propio texto, a la literatura en general, etc., y esa metatextualidad otorga un carácter particular a los pasajes en que "escribir», o «signo", por poner otros ejemplos, tiene lugar. $\mathrm{Y}$ es que ese tener lugar tiene lugar en el que es propiamente su lugar. A algunos comentarios sobre esta cuestión en la poesía de Pere Gimferrer es a lo que están dedicadas estas páginas. ${ }^{1}$

* Este trabajo se inscribe en el Proyecto de Investigación del Ministerio de Ciencia e Innovación FFI2009-13573, cofinanciado con fondos FEDER.

1 Y están dedicadas al profesor José Francisco Val, a mi querido amigo y compañero Pepe. 
Acudiendo a su libro más reciente, Rapsodia (2011), ya en el verso inicial, espléndido, se encuentra una manifestación de ese léxico: «Se ha desencuadernado por la mitad mi vida", verso que no puede sino hacer recordar el arranque de la Commedia y aun el eco de la Vita nuova, ${ }^{2}$ y con ese juego metafórico, ese doble juego, queda dicho cómo vida y escritura poética están tan estrechamente imbricadas que un término - «desencuadernar»— que es a fin de cuentas un derivado del escribir, por cuanto el libro es un objeto que depende de la escritura, un objeto que guarda lo escrito, se traslada al campo léxico de la primera o viceversa; o, mejor - ya se ha nombrado la dualidad- se proyecta uno sobre el otro con lo que ambos quedan mutuamente superpuestos — convendrá anotar además que la forma rítmica que sirve de vehículo, el alejandrino con sus dos hemistiquios, es la contrapartida fónica a la desencuadernación por la mitad-, prolongando, aunque aquí con una implicación de lo personal o íntimo, la vieja equiparación entre el libro y el mundo, o alguna de sus partes. El libro, esa unidad de cultura, es, pues, una imagen de la unidad y se equipara a la de la persona, con su principio y su fin y, claro está, todo el intermedio, además de que lo es del devenir, de la transformación, como en el discurrir del discurso. Y queda ahí nombrada la identidad de vida y escritura de Gimferrer, manifestada, y no es esto nada irrelevante, en la elección de lengua para la poesía: a los primeros libros en español le suceden los ciclos «l'agent provocador» en catalán y «Cuca de Cominges» de nuevo en español. ${ }^{3}$

La frase del verso citado no es una excepción, sino que encuentra algunos otros lugares similares en la poesía gimferreriana. Así, el léxico del campo del lenguaje irrumpe en frases como «no calen armes / per vèncer l'home: ja els llampecs en són un signe» («Agost», en Foc cec; Gimferrer 1995: 174), ante lo que cabe preguntarse: ¿en qué sentido los relámpagos

2 «Nel mezzo del cammin di nostra vita», por supuesto, es el verso primero de la Commedia; no menos por supuesto, este es el comienzo de Vita nuova: «In quella parte del libro de la mia memoria». Entre uno y otro dan: «la mitad», «la vida» y «el libro». Añadiré que la sombra de Vita nuova es particularmente relevante en los libros del ciclo gimferreriano «Cuca de Cominges» (véase Blesa 2010).

3 Véase Blesa 2010 y también Blecua 2009, quien en ese texto que no conocía al redactar mi trabajo citado habla de dos cancioneros, donde yo de ciclos, en la poesía gimferreriana anudados a la biografía. Los aludidos ciclos merecen, como bien dice Blecua, la denominación de cancioneros. 
son un signo de lo que se afirma? y, en cuanto signo, ¿cuál sería el significante y cuál el significado de tal signo? y ese extraño signo ¿đe qué sistema formaría parte?, pues ¿acaso es pensable un signo que sea único, que sea él mismo todo el sistema?, ¿dónde, entonces, el trabajo de la diferencia?; o, por poner otro ejemplo, «tantes sivelles diu la claredat / de perles llunyes d'un veler pirata» ("Medalló», en La llum; Gimferrer 1995: 316), de lo que surge la interrogación, al menos, sobre cuál pueda ser la lengua en que esa claridad habla y, también enigmática sin duda, esta otra: ¡será ella el único hablante? Y un caso más, que es un desarrollo del tipo anterior: «el silencio / de senderos y uvas nos responde» (II, Rapsodia; 2011: 21), en lo que mencionar el no hablar de senderos y uvas implica que podrían hacerlo; y quede advertido que en ese mismo libro se encuentran algunos otros ejemplos más.

Este tipo de construcciones tienen como eje la analogía entre la naturaleza y el libro, de manera que el cielo se torna legible, las estrellas hablan, etc., y es de una notabilísima antigüedad, como ya mostró Ernst Robert Curtius en uno de los capítulos de su Literatura europea y Edad Media latina, ${ }^{4}$ donde quedaba documentada desde textos de los pueblos de Asia occidental y Egipto, entre quienes «la escritura y el libro tenían ya, siglos antes de nuestra era, un carácter divino» (Curtius 1955: 425). Así, cuando Gimferrer concede el estatus de signo a los relámpagos no hace sino continuar esa ancestral analogía y podrá afirmarse que está también atribuyendo ese carácter divino o mágico a las cosas del mundo o, cuando menos, a algunas de ellas. De hecho, los relámpagos, la claridad, venga esta de donde venga, etc., son entes mudos y ágrafos para el común de los hablantes. Y, sin embargo, ciertos poetas oyen y leen allí donde ni hay habla ni escritura. Sucede, por poner algún otro ejemplo, con el agua, la madera y las nubes en estos otros versos: "Jo em llegia el destí en els signes de l'aigua i la fusta. / Era escrit en els núvols perduts, tots crines i fumera al cel groc» («Sonet», en Foc cec; Gimferrer 1995: 177). Adoptando la figura de mago, de vidente, el yo del poema lee el destino allí donde no hay, es evidente, escritura propiamente dicha, pese al «escrit» del texto. Son muestras de la adopción por parte del yo de la figura de mago o similar, digamos que de alguna

4 «El libro como símbolo», en su Literatura europea y Edad Media latina (1976: 423489), véase además, entre otros trabajos, La legibilidad del mundo de Hans Blumenberg (2000). 
forma de orfismo - en cualquier caso, un cierto tipo de iniciado en saberes esotéricos-, figura que, no hay duda, se da en la escritura, aunque no, desde luego, en el estatus social que quienes leían las estrellas tuvieron en el mundo antiguo y que no es el que la sociedad contemporánea concede a los poetas, pero esa es otra cuestión.

Esta concepción que equipara la escritura y las cosas, las cosas y el mundo, alcanza en la obra de Stéphane Mallarmé la referencia máxima en la modernidad en su gran proyecto de Libro, un único Libro, el gran análogon del Mundo — las mayúsculas son deuda mallarmeana-, pues, como dejó dicho en una famosa carta a Verlaine: «L'explication orphique de la Terre [...] est le seul devoir du poëte et le jeu littéraire par excellence.» (Mallarmé 1992: 663).

Ahora bien, esa "explicación órfica», ese conocimiento, para decirlo con un término algo menos grandilocuente, que el poeta ha de poner en sus textos se produce a través de una singular operación que lleva a cabo con el lenguaje y por la cual las palabras tienen un modo de existencia diferente, una existencia que es poética y sobre lo que Gimferrer ha ido dejando en diversos lugares su visión.

Volviendo ahora al ya citado Rapsodia, en la sección xIV, donde la mención de Góngora en su inicio es clave — «Góngora vive sólo en sus palabras»—, se lee

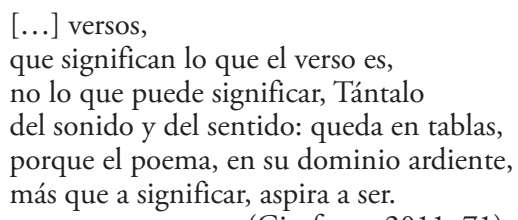

(Gimferrer 2011: 71).

Como es evidente, lo que ahí se afirma supone todo un reto, si es que no es una provocación, a lo que desde la lingüística, y aun desde el saber general de los hablantes sobre el lenguaje, se piensa sobre la significación: el tipo de texto que se conoce como poema dejaría atrás el deseo o la función, etc., de significar, o incluso renuncia a ello y tan solo «aspira a ser», a ser discurso que elude la significación. Con todo no puede pasarse por alto la mención de Tántalo inmediatamente anterior, lo que parece indicar que ni aun que se produjera el deseo o intento de alcanzar la significación, lo 
agónico que el personaje mitológico conlleva, esta está siempre presta a un movimiento de evasión del discurso, dejando a las palabras en un estado que habrá que nombrar como de asignificación o, al menos, como disponibles para una cierta significación que no es, sin embargo, la que significarían en su uso en otras modalidades distintas de la poética. A pasajes como el citado, en los que las palabras del texto se nombran a sí mismas, al lenguaje, me referí como «tránsitos» en Blesa (2010), adonde remito.

Años antes, en «Itinerari d'un escriptor», en 1989, citaba Gimferrer varios fragmentos poéticos y entre ellos los versos de Góngora que dicen "Quejándose venían sobre el guante / los raudos torbellinos de Noruega», a propósito de los cuales comentaba que

\footnotetext{
Non ens interessa que es digui que vénen uns falcons damunt d'un guant, acció que només tindria raó de ser si el llibre tractés de caceres.

El que crec és en la seva existencia verbal (Gimferrer 1997: 232).
}

Y, tras los aludidos ejemplos y algunos comentarios sobre ellos, Gimferrer concluirá con la idea de que lo propio de un poema es su «existència autònoma com a objecte verbal que arriba a denotar, per si mateix, una forma de coneixença no assolible per la parla habitual» (1997: 234-235).

Como queda ahora a la vista, lo central del ideario poético de Gimferrer radica en que cuando el poema es tal cosa alcanza un estatus que, renunciando a la referencialidad, a nombrar halcones noruegos sobre un guante, pongamos por caso, es expresión de conocimiento, claro que ese conocimiento es otro, o está expresado de un modo diferente, de lo que comúnmente se entiende por tal. Y por esa diferencia el discurso poético puede, o quizá incluso debe, transgredir las normas que rigen el habla en general, si es que no son sus transgresiones, con todas las implicaciones que ello conlleva, lo que establece de una vez por todas esa diferencia y son la esencia de lo poético. Aunque es muy evidente, no estará de más señalar que tal concepción de lo poético es coincidente con las propuestas del formalismo ruso y, en particular, de Roman Jakobson, es decir, de lo que fue la teoría de la vanguardia. ${ }^{5}$

5 Gimferrer pudo llegar a esta idea de lo literario por sí mismo o por medio de muy variadas lecturas, tanto literarias como teórico-críticas. Por tanto, sin pretender consignar aquí la fuente, sí anotaré que Gimferrer tradujo al español el libro de Michael Riffaterre Essais de stylistique structurale, donde se recoge esta teoría. Por ejemplo, en el capítulo «El 
Por tal singularidad, el habla del poema incide sin necesidad de explicaciones ni justificaciones en, por ejemplo, la contradicción, reprochable en cualquier otra manifestación ligüística salvo en casos como el chiste o en hablantes con patologías, como cuando se lee en L'espai desert: «Esclats. El verd és negre. El blau és blanc. [...] El blanc és verd» (Gimferrer 1995: 220), pasaje memorable que, a partir de la ceguera que producen unos resplandores - el texto podría dar a entender que la causa es el mirar directamente al Sol— da a leer la identificación, no puede obviarse el uso de la fórmula de la identidad "és», de aquello que es diferente y propone un repertorio cromático cuyo carácter es la inestabilidad, de donde se pasa a la intercambiabilidad de los componentes, con lo que el pasaje, pese a que se pueda proponer una lógica de la situación, una explicación, pone una resistencia tenaz, invencible, a la comprensión en su acepción más general, operación que queda como en suspenso. Ya Mallarmé dejó escrito en «La musique et les lettres» que «Strictement j'envisage, écartés vos folios d'études, rubriques, parchemin, la lecture comme une pratique désespérée» (1992: 647; la cursiva es mía). Tan desesperada debía de parecerle la lectura, la comprensión de la significación de los textos, que en uno de sus poemas pudo escribir una palabra de la que no tenía constancia de que existiera en francés ni en ninguna otra lengua, ese hápax que es "ptyx»: «Sur les crédences, au salon vide: nul ptyx» («Ses purs ongles...», Mallarmé 1992: 68) e incluso encontraba encantador el haberla escrito. ${ }^{6}$ En carta a Henry Cazalis dejó explicado que «J'extrais ce sonnet [...] d'une étude projetée sur la parole: il est inverse, je veux dire que le sens, s'il en a un [...] est évoquée par un mirage interne des mots mêmes» (1489), donde añadía misterio al misterio al dejar la duda sobre si carecería de sentido y, si lo tuviera, con la alusión a esa extraña operación sémica que exigiría desentrañar el espejismo interno de las palabras mismas. Sea como fuere, el caso es que la cuestión de la significación

formalismo francés» se lee: «la obra de arte como sistema autónomo de estructuras, es decir, independiente de la función referencial del lenguaje» (Riffaterre 1976: 320). El hecho es que, antes de traducir tal libro, la poesía de Gimferrer ya respondía a esos presupuestos.

6 A propósito del asunto escribe el poeta en una carta: «je fisse un sonnet, et que je n'ai que trois rimes en $y x$, concertes-vous pour m'envoyer le sens réel du mot ptyx: on m'assure qu'il n'existe dans aucune langue, ce que je préférerais de beaucoup à fin de me donner le charme de le créer par la magie de la rime» (Mallarmé 1992: 1488). No se puede dejar de anotar la existencia del soneto gimferreriano «Apoteosi» (Gimferrer 1995: 311), y el título ya es significativo, en el que «-ics», «-ix» es una de las rimas. 
encuentra en la práctica poética —y en la literaria en general, pues piénsese en las múltiples ocasiones en que parece quedar en suspenso en Finnegans Wake de Joyce- pasajes apurados, a los que quizá convendría considerar como de significación nula, para emplear el adjetivo mallarmeano, signos insignificantes, podría decirse, hechos de tan solo significantes. El propio Gimferrer lo ha advertido:

Las palabras pueden desvincularse no tan solo de su funcionalidad habitual sino incluso de su semántica y actuar como si fuesen sonidos en el espacio acústico o volúmenes y colores en el campo visual (Gimferrer, 2009: 63).

Por mucho que es en la modernidad cuando encuentra su gran momento de expresión, la cuestión del decir del poema, su puesta en crisis, tiene un antecedente ya absolutamente radical en la poesía provenzal. Me refiero, claro está, al verso «Farai un vers de driet nien» de Guilhem de Peitieu, ${ }^{7}$ y sobre el que Gimferrer ha escrito que:

El que resulta clar [...] és que ja, amb aquest poem remot, som decididament [...] en la regió on la literatura, més que no pas a esbrinar el paper de l'home en el joc còsmic, esmerça energies a fer-se i dir-se a si mateixa, a esdevenir una organització autònoma de material verbal (Gimferrer 1996: 65).

Si esa línea del trovador inaugura un espacio de escritura al deslizarla a «[l] a frontera del no-res» (ibíd.), es significativo que Gimferrer advierte allí mismo que «[d]'aquesta regió, no em sortim ni en Rimbaud ni en Mallarmé ni tan sols en Flaubert» (ibíd.), donde es notable que el uso del «nosotros» implica que él mismo se sabe habitante de tal región.

Es el escribir en esa frontera donde la nada linda con el decir donde el conocimiento está a la espera. Quizá no estará de más señalar que en la tradición poética española más inmediata esta misma idea, la de que el discurso poético es palabra de conocimiento, ha sido defendida por otros poetas más, entre ellos algunos muy relevantes como José Ángel Valente, Antonio Gamoneda, Clara Janés, José-Miguel Ullán o Andrés Sánchez Robayna, y con resultados textuales, por cierto, de toda excelencia.

7 En la obra de otro poeta coetáneo de Gimferrer y presente como él en Nueve novísimos poetas españoles (1970), la antología de José María Castellet, la de Leopoldo María Panero, el citado verso de Guilhem de Peitieu, y otros más suyos y también de otros provenzales, es cita reiterada en sus poemas e incluso ha traducido el poema en cuestión (Panero 2011: 198-203). 
Esta idea, que viene siendo una cuestión disputada tanto entre los poetas como en los estudios literarios, exige algunas palabras. Digamos para empezar que el conocimiento del que se habla es, sí, próximo al del discurso filosófico, al de la ciencia y de hecho se mantiene en continuo roce con ellos, como en una especie de contagio. Y no podrá ponerse en duda que el conocimiento, sea cual sea el calificativo que se le adhiera -lo que supone siempre circunscribirlo dentro de unos límites, es decir, unas limitaciones, con lo que se amputa algo a la noción misma de conocimiento-, no puede entenderse sino como el poner(se) el discurso en un cierto caminar hacia el conocimiento -el uso de "caminar» y enseguida el de «dar pasos» vienen dictados por la noción de movimiento que se contiene en «discurso»—, lo que implica que ese discurrir habrá de dar pasos en lo que necesariamente es desconocimiento, pues ¿qué conocimiento supondría decir lo conocido, repetirlo?, con lo que la palabra poética dice, o pretende decir, lo que se desconoce y, en cuanto que lo que se dice es desconocido, ¿cómo se puede saber de antemano, establecer desde lo conocido, cuáles habrían de ser las reglas a las que debería someterse el lenguaje del poema? En su función o aventura de dar a conocer lo desconocido el poema no puede decir lo que dice sino a su manera, a lo poético, de un modo que necesariamente ha de ser desconocido, al menos hasta que se da efectivamente como enunciado. Esto explica o justifica la singularidad de los usos verbales del lenguaje poético - pero también de todos de los que se pueden nombrar como «de conocimiento", siendo uno de ellos el de la lingüística—, sus tropos, sus elipsis, en fin, sus pasajes retóricos y, más en general, el desinterés por las máximas, la lógica de la conversación, como las que enunció H. Paul Grice (1975), que rigen el discurso en general. Esa cooperación de los hablantes de la que Grice habla estaría hiperdesarrollada, quizá como en ningún otro, en el caso del discurso de la poesía.

«Del mismo modo que el filósofo, el poeta busca y encuentra una verdad, del otro lado de las palabras y sin embargo a través de las palabras» ha escrito Gimferrer (2009: 65) y enseguida precisa que ese pensamiento que busca y encuentra «no nace necesariamente de conceptos, sino que puede nacer de las imágenes» (66), donde ese conocimiento aconceptual, dado en imágenes, viene a coincidir, en parte, con la exposición de Benedetto Croce en su fundamental Estetica come scienza dell'espresione e linguistica generale de 1902. Estas son sus primeras palabras: 
El conocimiento tiene dos formas. Es, o conocimiento intuitivo o conocimiento lógico, conocimiento por la fantasía o conocimiento por la inteligencia, conocimiento de lo individual o conocimiento de lo universal, de las cosas particulares o de sus relaciones. Es, en síntesis, o productor de imágenes, o productor de conceptos (Croce 1997: 35).

En parte, he escrito y así es. Como se ha visto, mientras Croce deja lo conceptual para el conocimiento lógico y lo excluye del estético, Gimferrer, desde una mirada más ambiciosa, afirma que el conocimiento poético se manifiesta tanto por medio de conceptos como de imágenes.

Entre estos conceptos e imágenes, creo, están aquellos pasajes que incluyen algún término lingüístico por cuanto suponen un desafío a la comprensión inmediata y remiten de algún modo a la explicación órfica de la que habló Mallarmé. La palabra poética sería una, o la, explicación de la realidad, según se lee en estos versos:

[...] el poema alhora pateix de la imperiosa necessitat de designar el real i no el pot designar: li calen les paràfrasis

per al.ludir al trànsit d'un núvol

[...]

Així, doncs, la paraula esdevindrà parany.

(Gimferrer 1995: 110).

De acuerdo con ello, lo que se lee no es exactamente lo que querría decir la frase (véase "paráfrasis» en el $D R A E$, donde se habla de "traducción» a la que le falta una «escrupulosa exactitud» o de «imitación» pero «con palabras diferentes»), aunque sí contendría lo que se querría decir con ella solo que la palabra ha pasado a ser "parany». ${ }^{8}$ Así, paráfrasis, en cuanto que no phrásis, en cuanto frase que no es $l a$ frase - el texto-, sino otra que está junto a ella, pará-, o con la que guarda relación y es en esta relación donde la significación, el sentido, la comprensión están puestos en juego, lo que hace, sí, de la lectura una práctica desesperada, donde quizá se deba entender que la significación, etc., están a la espera en su ocultación, su encubrimiento.

También en estado de ocultación, de encubrimiento está todo lo que las cosas dicen, lo que en ellas se lee, pues ¿qué habrá de entenderse en «el dia esdevé un mot» (Gimferrer 1995: 290)?, ¿tan solo que la cosa día es

8 También se lee en DRAE: «Explicación o interpretación amplificativa de un texto para ilustrarlo o hacerlo más claro o inteligible», solo que a esa inteligibilidad se llega por la oscuridad de la palabra poética: ¿obscurum per obscurius? 
nombrada «dia»?, demasiado simple; ¿qué en «la vida es ya metáfora de vida»? (Gimferrer 2011: 27) y así se podrían engarzar preguntas una tras otra sin poder empezar a dar respuestas. Lo advierte el propio poeta:

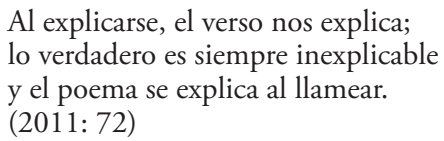

Digamos, quizá contaminados por ese modo de decir, que en ese mismo fuego arde la lectura.

No hay nada más verdadero que la realidad, que las cosas mismas, tangibles, visibles, mostrándose sin intermedio de lenguaje alguno, solo por su propia presencia, y ese "lo verdadero", dice el poema, "es siempre inexplicable», de manera que nada hay que explicar, las palabras se bastan a sí mismas, como si fuesen cosas y no signos, o, sin más, siendo cosas.

Pero ¿̇es que son cosas? Por lo que se deduce de todo esto, para el poeta, para Pere Gimferrer, para la poesía, las palabras sí son cosas y, por tanto, la significación de cada una de ellas habrá de ser su significante, extraña amalgama de lo que se piensa habitualmente como entidades diferentes.

Pero ¿es que las palabras son cosas? Para responder de nuevo a esta pregunta, desesperada, no encuentro ahora otro modo que el tomar, dar, la palabra a Gimferrer:

\author{
SIGNE \\ El món és una al.legoria. \\ És cabalístic el dibuix \\ amb què el cel nítid expia \\ l'ocell, ombra sense gruix. \\ No res: tan sols una unglada \\ en la llisor aserenada \\ del firmament esbandit. \\ Clarianes! La contrada \\ n'estrafa una altra, celada \\ en un invisible escrit. \\ (1995: 267)
}

Según dice «Signe», el mundo es un libro —y otorga con ello la primacía al lenguaje-, el libro, texto que está ahí a la espera de ser leído, pero 
lo que dice, por decirlo de un modo alegórico, ni debe ni puede ser tomado literalmente, sino por sustitución de cada palabra por otra, claro que sin dar la clave que necesariamente habrá de ser aplicada para comprender el sentido inscrito allí bajo el silencio del tropo.

\section{Referencias}

Blecua, A. (2009): «Discurso de contestación», Barcarola, 93: 72-81.

BlesA, T. (2010): Gimferrerías, Zaragoza, Eclipsados.

Blumenberg, H. (2000): La legibilidad del mundo, trad. P. Madrigal Devesa, Barcelona, Paidós.

Croce, B. (1997): Estética como ciencia de la expresión y lingüistica general, intr. P. Aullón de Haro y J. García Gabaldón, trad. Á. Vegue i Goldoni, Málaga, Ágora.

Curtius, E. R. (1976): Literatura europea y Edad Media Latina, trads. M. Frenk Alatorre y A. Alatorre, Madrid, Fondo de Cultura Económica, 2. ${ }^{a}$ reimpr.

Gimferrer, P. (1995): Obra catalana completa/1. Poesia, intr. A. Terry, Barcelona, Edicions 62.

- (1996): Obra catalana completa/3. Dietari complet, 2 (1980-1982), intr. A. Terry, Barcelona, Edicions 62.

- (1997): «Itinerari d'un escriptor», en Obra catalana completa/5. Assaigs crítics, intr. E. Bou, Barcelona, Edicions 62: 211-235.

- (2009): «Reflexiones sobre la palabra poética», Barcarola, 93: 59-70.

- (2011): Rapsodia, Barcelona, Seix Barral.

Grice, H. P. (1975): «Logic of conversation», en Syntax and Semantics, vol. 3, «Speech Acts», ed. P. Cole y J. L. Morgan, Nueva York, Academic Press: 41-58.

Mallarmé, S. (1992): Oeuvres complètes, ed. H. Mondor y G. Jean-Aubry, París, Gallimard.

Panero, L. M. (2011): Traducciones/Perversiones, ed. T. Blesa, Madrid, Visor.

Riffaterre, M. (1976): Ensayos de estilistica estructural, trad. P. Gimferrer, Barcelona, Seix Barral. 



\section{PARTE II \\ HISTORIA DE LA GRAMÁTICA: NIVELES, UNIDADES Y TRADICIONES}





\title{
LA DOMESTICACIÓN DE UN SALVAJE: BREVE REPASO HISTÓRICO A LA FONOLOGÍA DE LA ENTONACIÓN
}

\author{
Javier Simón Casas \\ (Universidad de Zaragoza)
}

\section{Introducción}

En esta contribución realizaremos una breve presentación del camino recorrido hasta llegar a la fonología entonativa actual. El modelo más utilizado actualmente para explicar el fenómeno que nos ocupa es el llamado autosegmental-metrical (AM) (Beckman y Venditti 2011). La denominación del marco teórico fue acuñada por Robert Ladd, quien la ha presentado en dos ediciones sucesivas de una monografía (Ladd 1996, 2008). Si pensamos que la entonación es un fenómeno susceptible de tener una interpretación fonológica, deberemos encontrar dentro de él un conjunto de unidades y de relaciones.

Un primer problema que suele plantearse es el relativo a la definición del propio término entonación. Este se refiere a la melodía que acompaña a las frases. Esta se genera por la frecuencia fundamental $\left(f_{0}\right)$ que, a su vez, se determina por las sucesivas aperturas y cierres de los pliegues vocales - pulsos glotales - durante la fonación. Cuanto más elevada es la $f_{0}$ durante la pronunciación de una sílaba o de una unidad mayor, más aguda es la sensación de tono que se percibe. 
La $f_{0}$ puede variarse voluntariamente hasta cierto punto. La limitación viene dada por los límites fisiológicos impuestos por la forma y el estado de las estructuras laríngeas. Así, la edad, el sexo, el estado de salud, el ambiente y las características genéticas individuales determinan lo que se denomina la tesitura o rango de la voz (organic range, Laver 1994). Se trata del recorrido en hercios $(\mathrm{Hz})$ que, en condiciones normales, los pliegues vocales permiten entre las frecuencias más bajas y las más altas (Mackenzie Beck 2010). Se han realizado algunos experimentos para averiguar los valores medios de la tesitura. Por ejemplo, Laver (1994) señala que los valores mínimos y máximos oscilan entre los 50 y los $250 \mathrm{~Hz}$ para la voz masculina adulta y entre los 120 y los $480 \mathrm{~Hz}$ para la voz femenina adulta. En cuanto a las medias de $f_{0}$ proporciona unos valores de $120 \mathrm{~Hz}$ para los hombres, $220 \mathrm{~Hz}$ para las mujeres y $330 \mathrm{~Hz}$ para los niños. Otros datos se pueden encontrar, por ejemplo, en Quilis (1981), Ball y Rahilly (1999), Prieto Vives (2002), o Reetz y Jongman (2009), entre otros.

Dentro de la tesitura permitida fisiológicamente, la variación de la frecuencia de los pulsos glotales puede modificarse a voluntad. Para ello, los hablantes ajustan finamente la masa efectiva y la rigidez de los pliegues vocales. Del intrincado complejo de músculos de la laringe, el que interviene directamente en la variación voluntaria del tono es el músculo cricotiroideo. También participa, aunque en menor medida, el músculo tiroaritenoideo (Hirose 2010). Es precisamente esta variación voluntaria del tono la que permite que percibamos la melodía que acompaña a los segmentos fonéticos.

La entonación también debe distinguirse de otro fenómeno muy extendido en las lenguas del mundo. Nos referimos al uso de la variación de la $f_{0}$ para realizar distinciones léxicas o gramaticales de un modo similar a como las lenguas de nuestro entorno utilizan las consonantes o las vocales. Las lenguas que utilizan este procedimiento se denominan tonales. No se trata de lenguas marginales, raras o con pocos hablantes. Entre el 60 y el $70 \%$ de las lenguas del mundo son lenguas de este tipo. $Y$ la lengua con mayor número de hablantes en el mundo, el mandarín, es una lengua tonal (Yip 2002). La distribución geográfica de esta clase de lenguas se encuentra especialmente en América central, África y el sudeste asiático (Laver 1994). Algunas lenguas europeas, escasas, también exhiben las distinciones tonales: serbocroata, lituano o algunos dialectos del vascuence, entre otras (Yip 2002). 
Podemos definir entonación como las variaciones de $f_{0}$ que acompañan a unidades prosódicas mayores que la sílaba y tienen fines distintos al contraste léxico o gramatical. Las funciones típicas de la entonación son discursivas, marcadoras de la modalidad, de focalización o demarcadoras de unidades. Por otro lado, la información del tono se ve acompañada por otros indicios fonéticos que colaboran en la percepción de la melodía. Nos estamos refiriendo a cambios estratégicos de la intensidad y de la duración.

Por otra parte, además de estas funciones, la entonación refleja perfectamente todo un conjunto de informaciones de naturaleza paralingüística en el sentido de Trager (1966). Así, a través del tono podemos percibir aspectos como el sexo del hablante, su estado emocional o su interés por la conversación. Por tanto, la información lingüística y paralingüística vienen empaquetadas juntas en el mismo canal a la hora de emitir los mensajes. Este punto no ha pasado desapercibido a quienes han negado un estatus fonológico al fenómeno entonativo. No obstante, como señala Ladd (2008), la coincidencia de ambos canales no enturbia la información de carácter puramente lingüístico.

En lo sucesivo, revisaremos brevemente las opiniones de quienes niegan que la entonación sea reductible a unidades y relaciones. Después, presentaremos algunas corrientes de análisis que han tratado el fenómeno desde un punto de vista fonológico, sea de un modo explícito o implícito. Terminaremos con una breve presentación del modelo AM, tal y como se entiende en la actualidad.

\section{El estructuralismo europeo}

Puede parecer que las corrientes estructuralistas de este lado del Atlántico no han prestado la debida atención al fenómeno de la entonación. Esta idea no es del todo exacta. Ha habido autores que han negado cualquier estatuto fonológico a la entonación pero, en general, encontramos una cierta preocupación por este aspecto en el estructuralismo europeo, sobre todo en la escuela de Praga.

El autor que se cita habitualmente como el adalid de la irreductibilidad de la entonación a unidades y relaciones es Martinet (1960). Este autor no niega un cierto carácter lingüístico a la entonación, pero esta queda 
fuera de la doble articulación, ya que no podemos descomponer sus unidades en fonemas. Apela a una función más bien expresiva de la entonación. Por otro lado, considera que el descenso de la $f_{o}$ al final de los enunciados es una tendencia a la economía y, por tanto, debe ser un rasgo universal.

Esta misma universalidad es la que hace dudar a Bolinger (1964) de que se pueda conseguir tratar la entonación con los procedimientos propios de la lingüística. En la discusión de este mismo trabajo de Dwight L. Bolinger, autores como Strang, Daneš o Morgan critican la supuesta universalidad de la entonación. Más tarde, Bolinger (1978) insistía en la dificultad de describir la entonación de acuerdo con las estructuras propias de la morfología o la fonología. Llegó a llamar a la entonación «a half-tamed savage», expresión a la que aludimos en el título. Al menos, reconoce que la mitad es reductible a la estructuración. Se trata del problema, ya comentado arriba, del empaquetado de diversa información dentro de un mismo canal.

Otros autores estructuralistas, aunque no europeos, como Arisaka (1940) o Hultzén (1964), insisten también por distintas razones en negar a la entonación una categoría dentro de la forma lingüística. El primero, por ejemplo, señala que la entonación es un fenómeno de orden estrictamente fisiológico.

No obstante, en el ámbito de la escuela praguense sí que hubo una preocupación por los elementos suprasegmentales, aunque el inmenso trabajo realizado en el campo segmental oscureció las ideas sobre aquellos. No debemos perder de vista que el interés de Roman Jakobson por el lenguaje le vino a partir de su vocación por la poesía. Realizó algunos trabajos sobre métrica eslava e indoeuropea. En realidad, lo que supuso una ruptura radical de la escuela praguense con las ideas anteriores sobre fonología (principalmente, la escuela de Kazan con Baudouin de Courtenay y Kruszewski) fue su preocupación por propiedades fónicas cuya vinculación con la estructura segmental se puede considerar, como mucho, laxa (Anderson 1985).

De hecho, en el código de la fonología de la escuela de Praga (Anderson 1985), los Principios de fonología de Trubetzkoy, se presenta un extenso y documentado estudio, junto a su interpretación, de propiedades de lenguas tonales y de lenguas que utilizan la duración de un modo fonológico, así como de la naturaleza del acento. Estas propiedades, aunque aparecen 
en los segmentos, poco tienen que ver con este y sí que funcionan en el nivel silábico como unidad mínima. Este autor también confiere carácter fonológico a la entonación: "la 'entonación' es en estas lenguas solo un medio fonológico para diferenciar las frases» (Trubetzkoy 1939: 201). ${ }^{1}$

También Hjelmslev continuó con esta tradición y asignó un papel funcional a la entonación. Su teoría de los suprasegmentos recuerda mucho a las ideas centrales de la fonología prosódica actual. La división de los enunciados en unidades jerárquicas con distintas propiedades es común a las dos teorías (Anderson 1985).

\section{La escuela británica ${ }^{2}$}

La escuela británica hunde sus raíces en una rica tradición de estudios fonéticos. Cuenta con antecedentes tan importantes como los fonetistas Alexander Graham Bell, Henry Sweet o Daniel Jones. Esta escuela se ha mostrado bastante independiente tanto de Europa como de Estados Unidos con respecto al desarrollo fonético y fonológico. Frente a las corrientes comentadas arriba — de naturaleza más teórica - la escuela británica ha tenido un carácter marcadamente práctico. Es famoso, a este respecto, el comentario de Householder (1952: 100) en su reseña a Jones (1950): «The European asks 'Is it true?,' the American 'Is it consistent?,' the Englishman 'Will it help?'». ${ }^{3}$ La gran preocupación de esta escuela desde el principio fue la aplicación de sus descubrimientos a la enseńanza de lenguas, principalmente el inglés como segunda lengua. El citado interés produjo una serie de excelentes descripciones de la entonación del inglés: Palmer (1922), Armstrong y Ward (1926), Kingdon (1958), Schubiger (1958), O’Connor y Arnold (1961), Crystal (1969) o Halliday (1970).

Todos estos manuales, como puede adivinarse por algunos de sus títulos, tratan la entonación del inglés desde un punto de vista más bien didáctico. Sin embargo, consiguieron realizar una seria sistematización que Ladd

1 Las comillas internas a la cita son textuales.

2 Para un resumen más exhaustivo de los modelos que vamos a presentar a partir de ahora, puede consultarse la edición de Prieto (ed.) (2003). En ella especialistas en cada paradigma explican detalladamente dichas teorías.

3 Las comillas internas a la cita son textuales. 
(2008: 11) denominó como «proto-phonological». Estos trabajos tuvieron en común un modelo de explicación de la entonación basado en las llamadas configuraciones.

Todos ellos operan con algún tipo de unidad entonativa que puede recibir diversas denominaciones. Estos grupos tienen una estructura interna. Todo grupo debe tener un acento tonal (pitch accent); se trata de un acento que corresponde a una sílaba con posibilidad de relevancia desde el lexicón y que presenta un movimiento importante de variación tonal que incluso afecta a las sílabas vecinas. Este acento tonal obligatorio constituye el núcleo de la unidad tonal. Si hay varios acentos tonales en la secuencia, suele considerarse como núcleo el último de ellos.

Resultan importantes las sílabas no acentuadas ${ }^{4}$ posteriores al núcleo, la llamada cola (tail). El último acento tonal proyecta sobre la cola parte de su movimiento tonal. Es por ello por lo que algunos autores consideran que el núcleo está compuesto por la sílaba con acento tonal más la cola. El término tonema de Navarro Tomás (1944: p. 69; \$21) se inserta en esta tradición:

La parte con que termina la unidad melódica comprende las sílabas finales, a partir de la que lleva el último acento. [...] Como elementos típicos en que concurren caracteres representativos y funcionales, estos tonos que cierran la línea de las unidades enunciativas pueden recibir propiamente el nombre de «tonemas». ${ }^{5}$

Según los autores que se consulten, se puede encontrar un número mayor o menor de tipos de núcleo. Por ejemplo, O'Connor y Arnold (1961) señalan siete núcleos distintos para el inglés. Navarro Tomás (1944) distingue cinco tipos para el español: tonemas de cadencia, anticadencia, semicadencia, semianticadencia y suspensión.

En la zona prenuclear, suelen distinguirse dos partes: head y pre-head (cuerpo e inflexión inicial en Navarro Tomás 1944). En el cuerpo puede haber varios acentos tonales no nucleares. Es la parte previa al núcleo que abarca desde la sílaba que lleva el primer acento tonal (incluida) hasta el

4 Evitamos intencionadamente los términos tónico o átono como sinónimos de acentuado o no acentuado. Silaba tónica significa sílaba relevante por su tono. Puede haber una sílaba acentuada pero sin relevancia tónica (Navarro Tomás 1918: pp. 21-22 y 25; \$\$ 22 y 28).

5 Las comillas son originales del texto. 
último acento tonal (excluido). Las sílabas inacentuadas iniciales constituyen la inflexión inicial. La importancia que se da a estas dos partes varía de unos autores a otros. Por ejemplo, Navarro Tomás (1944) señala que en el cuerpo se encuentran las diferencias entre las distintas lenguas. Por otro lado, señala que en la inflexión inicial ya se puede encontrar una diferencia entre la entonación de los enunciados declarativos y los interrogativos del español.

Este tipo de análisis por configuraciones se denomina así porque considera que la unidad entonativa completa (inflexión inicial, cuerpo, núcleo y cola) tiene una función semántica. Es decir, una configuración global particular presenta un significado distinto del de otras posibles configuraciones. Por tanto, el uso de una u otra configuración posee valor distintivo.

Fuera de la escuela británica, este modelo de configuraciones también lo podemos ver aplicado en la escuela holandesa con su modelo denominado IPO, siglas que hacen referencia al instituto donde surgió: Institute for Perception Research. Se dedicó desde principios de la década de los sesenta al estudio de la percepción. El equipo responsable del área de entonación estuvo dirigido por tres investigadores: Johan 't Hart, Antonie Cohen y René Collier. Sus ideas han gozado de una gran reputación en el campo de la entonación. Un compendio de sus principios se puede encontrar en ' $t$ Hart, Collier y Cohen (1990).

\section{La entonación en la lingüística norteamericana}

Mientras la escuela británica defendía un modelo descriptivo de la entonación mediante configuraciones, al otro lado del Atlántico los lingüistas norteamericanos describían el mismo fenómeno mediante niveles. Esto es, el hablante asigna a las sílabas con acento tonal un determinado nivel de tono. La configuración se obtendrá por la unión de estos niveles entre sí, pero no es un asunto fonológico sino de implementación fonética. La perspectiva es claramente distinta.

Al igual que lo ocurrido con las configuraciones, también hubo una serie de trabajos que describía la entonación del inglés de acuerdo con un modelo de niveles: Pike (1945), Wells (1945) o Trager y Smith (1951), por ejemplo. Del mismo modo que no había consenso en cuanto al número de 
configuraciones, tampoco lo hay en lo que respecta al número de niveles necesarios para describir las lenguas particulares.

Por tomar un ejemplo, Trager y Smith (1951) defienden la existencia de cuatro niveles tonales. Junto a estos postulan como necesarios cuatro tipos de acentos, una juntura interna y tres junturas terminales. En lo que se refiere a los acentos, distinguen tres niveles acentuales más el nivel de las sílabas que están inacentuadas. La juntura interna vendría a ser el límite de las palabras que no tiene demasiada influencia en la entonación. Finalmente, las junturas terminales se refieren a los cambios de tono que aparecen en los límites de los grupos entonativos.

Lo importante de todos modos es que postulan cuatro niveles tonales para el inglés. Cada uno de ellos constituye un fonema. Son el mismo número que los que se encuentran en los trabajos comentados arriba (Pike 1945 y Wells 1945). Los niveles tienen valores relativos y no absolutos. Cada uno de los tonos posee, a su vez, cuatro realizaciones alofónicas distintas. En las junturas terminales se pueden producir los tres finales típicos de las terminaciones de grupo de entonación: suspensión, elevación o descenso. Todo este sistema de tonos, acentos y junturas determina la entonación de las frases.

Ha habido varias aplicaciones de este modelo al español; por ejemplo, Stockwell, Bowen y Silva-Fuenzalida (1956), Silva-Fuenzalida (1956-7), la traducción española de Hockett (1958) —(Hockett 1964)—, o Quilis (1981, 1993), entre otros.

\section{Hacia el modelo AM de la fonología entonativa}

Precisamente las críticas a este modelo de análisis de la entonación mediante niveles ayudaron a configurar el actual modelo AM. Una parte de las críticas se refería al número de niveles. Así, por ejemplo, Cruttenden (1986) señala que la mayor parte de los tonos nucleares del inglés británico se pueden describir perfectamente con tres niveles. Pero, si se quieren abarcar todos los casos posibles, no es suficiente con cuatro.

Hay dos trabajos clave en el nacimiento de este modelo de entonación. Se trata de las tesis doctorales de Bruce (1977) y, especialmente, de Pierrehumbert (1980). El primero mostró algunos puntos clave en su aná- 
lisis de la entonación del sueco. En primer lugar, advirtió la importancia de los puntos de cambio (turning points) de la $f_{0}$. Se trata de puntos máximos y mínimos de frecuencia que se sincronizan en el tiempo de un modo muy preciso con la cadena segmental. Por otro lado, se percató de que el contorno de $f_{0}$ es el resultado final de la interacción de elementos de diversa naturaleza. En el caso del sueco, la entonación final depende de los acentos tonales léxicos, de los acentos tonales en la frase y de las junturas terminales. Estos elementos no actúan en niveles distintos, sino que se concatenan.

La teoría AM también hunde sus raíces en la fonología autosegmental ideada en los años setenta del siglo pasado a partir, sobre todo, de las tesis doctorales de Leben (1973) y Goldsmith (1976). Esta teoría surgió como una necesidad de encontrar explicación a determinados fenómenos de las lenguas tonales africanas.

Con estas dos teorías presentes, Pierrehumbert realizó un análisis de la entonación del inglés. La inició en su tesis doctoral (Pierrehumbert 1980) y la desarrolló más ampliamente en Beckman y Pierrehumbert (1986) y Pierrehumbert y Beckman (1988). A partir de estos trabajos, se fue conformando la teoría AM de la fonología entonativa tal y como la conocemos en la actualidad.

Desde entonces, el análisis dentro de este marco se ha aplicado al estudio de la entonación de diversas lenguas. Como muestra, puede servir la edición de Jun (2005), donde se realiza un análisis de trece lenguas de acuerdo con este marco. Para el español se han realizado algunos análisis. Recientemente se ha editado un estudio completo sobre diversas variedades del español (Prieto y Roseano 2010). Con anterioridad, el trabajo clásico sobre la fonología de la entonación del espańol, de acuerdo con este modelo, ha sido el de Sosa (1999).

Terminamos con la presentación de las ideas básicas de este enfoque, tal y como aparecen en lo que se considera la obra básica sobre el modelo (Ladd 2008: 44). Esta teoría se apoya en cuatro principios fundamentales:

1. La estructura tonal se basa en una serie secuencial de eventos (acentos tonales y tonos de frontera) que se asocian con determinados puntos del estrato segmental.

2. Los acentos tonales son rasgos propios del estrato tonal, aunque pueden servir para otros fines. 
3. Los acentos tonales se analizan por medio de dos tonos de nivel: $\mathrm{H}$ (alto/high) y L (bajo/low). Son «dianas» (targets) hacia las que el hablante dirige su tono.

4. La realización fonética concreta de los tonos depende de varios factores independientes de su propia naturaleza como $\mathrm{H}$ o L. El contorno global de $f_{0}$ refleja los eventos locales y su realización fonética.

\section{Referencias}

Anderson, S. R. (1985): Phonology in the twentieth century, Chicago, The University of Chicago Press.

Arisaka, H. (1940): Phonology, Tokio, Sanseido.

Armstrong, L. E. e I. C. WARD (1926): Handbook of English Intonation, Leipzig, Teubner.

Ball, M. J. y J. Rahilly (1999): Phonetics: The Science of Speech, Londres, Arnold. Beckman, M. E. y J. B. Pierrehumbert (1986): «Intonational structure in Japanese and English», Phonology Yearbook, 3: 255-309.

- y J. J. VenditTi (2011): «Intonation», en Goldsmith, Riggle y Yu (eds.), The Handbook of Phonological Theory, Oxford, Wiley-Blackwell, 2. ${ }^{\text {a }}$ ed.: 485-532.

Bolinger, D. L. (1964): «Intonation as a Universal», en Lunt (ed.), Proceedings of the Ninth International Congress of Linguists: Cambridge, Mass., August 27-31, 1962, La Haya, Mouton: 833-848.

- (1978): «Intonation Across Languages», en Greenberg, J. (ed.), Universals of Human Language, Stanford, Stanford University Press: 471-524.

Bruce, G. (1977): Swedish Word Accents in Sentence Perspective, tesis doctoral, recuperada de http://www.lunduniversity.lu.se/o.o.i.s?id=24732\&postid=528888.

Cruttenden, A. (1986): Intonation, Cambridge, Cambridge University Press.

Crystal, D. (1969): Prosodic Systems and Intonation in English, Cambridge, Cambridge University Press.

Goldsmith, J. A. (1976): Autosegmental Phonology, tesis doctoral, recuperada de http://dspace.mit.edu/bitstream/handle/1721.1/16388/03188555.pdf? sequence $=1$.

Halliday, M. A. K. (1970): A Course in Spoken English: Intonation, Londres, Oxford University Press.

Harcastle, W. J., J. Laver y F. E. Gibbon (eds.) (2010): The Handbook of Phonetic Sciences, Oxford, Wiley-Blackwell, 2. ${ }^{\mathrm{a}}$ ed.

Hirose, H. (2010): «Investigating the Physiology of Laryngeal Structures», en Hardcastle, Laver y Gibbon (eds.): 130-152. 
Hocketт, C. F. (1958): A Course in Modern Linguistics, Nueva York, Mcmillan. - (1964): Curso de lingüistica moderna, Buenos Aires, Eudeba.

Householder, F. W., jr. (1952): «Untitled [Reseña a Jones (1950)]», International Journal of American Linguistics, 18.2: 99-105.

HultzéN, L. S. (1964): «Grammatical Intonation», en Abercrombie et al. (eds.), In Honour of Daniel Jones: Papers Contributed on the Occasion of His Eightieth Birthday, 12 de septiembre de 1961, Londres, Longmans: 85-95.

Jones, D. (1950): The Phoneme: Its Nature and Use, Cambridge, Heffer.

Jun, S. (ed.) (2005): Prosodic Typology: The Phonology of Intonation and Phrasing, Oxford, Oxford University Press.

Kingdom, R. (1958): The Groundwork of English Intonation, Londres, Longman. LADD, D. R. (1996): Intonational Phonology, Cambridge, Cambridge University Press.

- (2008): Intonational Phonology, Cambridge, Cambridge University Press, $2 .^{\mathrm{a}} \mathrm{ed}$.

Laver, J. (1994): Principles of Phonetics, Cambridge, Cambridge University Press. Leben, W. (1973): Suprasegmental Phonology, tesis doctoral, recuperada de http:// dspace.mit.edu/bitstream/handle/1721.1/16364/04430493.pdf? sequence $=1$.

Mackenzie Beck, J. (2010): «Organic Variation of the Vocal Apparatus», en Hardcastle, Laver y Gibbon (eds.): 155-201.

Martinet, A. (1960): Éléments de linguistique générale, París, Armand Colin.

Navarro Tomás, T. (1918): Manual de pronunciación española, Madrid, Centro de Estudios Históricos.

- (1944): Manual de entonación española, Nueva York, Hispanic Institute in the United States.

O'Connor, J. D. y G. F. Arnold (1961): Intonation of Colloquial English: a Practical Handbook, Londres, Longman.

Palmer, H. E. (1922): English Intonation with Systemic Exercises, Cambridge, Heffer.

Pierrehumbert, J. B. (1980): The Phonology and Phonetics of English Intonation, tesis doctoral, recuperada de http://dspace.mit.edu/bitstream/handle/1721. 1/16065/07492108.pdf.

- y M. E. Beckman (1988): Japanese Tone Structure, Cambridge (Mass.), MIT Press.

Pike, K. L. (1945): The Intonation of American English, Ann Arbor, University of Michigan Press.

Prieto Vives, P. (2002): Entonació: Models, teoría, mètodes, Barcelona, Ariel.

- (ed.) (2003): Teorías de la entonación, Barcelona, Ariel.

- y P. Roseano (eds.) (2010): Transcription of Intonation of the Spanish Language, Múnich, Lincom. 
Quilis, A. (1981): Fonética acústica de la lengua española, Madrid, Gredos.

- (1993): Tratado de fonología y fonética españolas, Madrid, Gredos.

Reetz, H. y A. Jongman (2009): Phonetics: Transcription, Production, Acoustics, and Perception, Oxford, Wiley-Blackwell.

Schubiger, M. (1958): English Intonation: its Form and Function, Tubinga, Max Niemeyer Verlag.

Silva-Fuenzalida, I. (1956-7): «La entonación en el español y su morfología», Boletin de Filología, 9: 177-187.

Sosa, J. M. (1999): La entonación del español: Su estructura fónica, variabilidady dialectología, Madrid, Cátedra.

Stockwell, R. P., J. D. Bowen e I. Silva-Fuenzalida (1956): «Spanish Juncture and Intonation", Language, 32.2: 641-665.

'T Hart, J., R. Collier, y A. Cohen (1990): A Perceptual Study of Intonation: An Experimental-Phonetic Approach to Intonation, Cambridge, Cambridge University Press.

Trager, G. L. (1966): «Paralanguage: A First Approximation», en Hymes (ed.), Language in Culture and Society: A Reader in Linguistics and Anthropology, Nueva York, Harper \& Row: 274-288.

- y H. L. Sмiтh, Jr. (1951): An Outline of English Structure, Norman, Battenburg Press.

Trubetzkoy, N. S. (1939): Grundzüge der Phonologie, Prague [Travaux du cercle linguistique de Prague, 7]. Citado por la traducción española Principios de fonología, Madrid Cincel, 1949.

Wells, R. S. (1945): «The Pitch Phonemes of English», Language, 21.1: 27-39.

YIP, M. (2002): Tone, Cambridge, Cambridge University Press. 


\section{NOVENTA AÑOS DE DESCRIPCIÓN DE LA MORFOLOGÍA LÉXICA ESPAÑOLA: TRATADOS DE FORMACIÓN DE PALABRAS EN ESPAÑOL (1920-2010)}

David Serrano-Dolader

(Universidad de Zaragoza)

\section{Introducción}

Intentar condensar noventa años de investigación sobre morfología léxica del español en unas pocas páginas sería tarea condenada al fracaso si se aspirara a dar cuenta cabal del periodo que es objeto de atención. No se pretende ello aquí, sino simplemente ofrecer un listado, comentado y ordenado cronológicamente, de las distintas obras que, entre 1920 y 2010, se han ocupado - con pretensión globalizadora y fundamentalmente descriptiva- de los procedimientos de formación de palabras en nuestra lengua. En suma, se trata de ofrecer una breve guía sobre lo que, de modo más o menos laxo, podemos considerar tratados sobre lexicogénesis del español. Ello obliga a reconocer que algunas de las obras incluidas en este breve artículo no son, estrictamente hablando, verdaderos tratados; como necesario es admitir también que algunos trabajos no incluidos en nuestro listado podrían ser calificados por otros estudiosos como auténticos tratados sobre formación de palabras.

Algo que parece menos discutible es la operatividad del lapso temporal seleccionado para este breve repaso: en 1920 aparece la que podemos 
considerar primera obra de conjunto sobre procedimientos de creación léxica en español (Alemany Bolufer 1920), y cuando apenas faltaban unos días para 2010 fue presentada la Nueva Gramática de la Lengua Española, que incluye siete amplios capítulos dedicados a la formación de palabras. Son noventa años de muy irregular peso en la parcela que analizamos. Desde 1920 hasta 1970, el vacío más absoluto; desde 1970 hasta 1993, y salvo alguna honrosa excepción, breves tratados divulgativos. Desde 1993 hasta 2010, periodo de pleno florecimiento de tratados lexicogenéticos de diversa amplitud e interés, y vertebrados por dos hitos fundamentales: la aparición de la monumental obra de Rainer (1993), que sigue siendo hoy por hoy el estudio globalizador más completo sobre morfología léxica del español; y la atención pormenorizada a los diversos procesos de formación de palabras por parte de las dos obras gramaticales más ambiciosas de los últimos tiempos, tanto la Gramática Descriptiva de la Lengua Española (1999) como la Nueva Gramática de la Lengua Española (2009).

Toda selección bibliográfica obliga a dejar fuera de ella algunos trabajos que, de asumir perspectivas más amplias o disponer de mayor espacio, merecerían atención por guardar relación notable con la parcela que aquí hemos acotado. Sin posibilidad ahora de justificar razonadamente ausencias, sí apuntamos no obstante algunas carencias que el lector podrá encontrar en nuestra selección posterior:

- Hemos seleccionado tratados centrados exclusivamente en el español. Quiere ello decir que han quedado fuera, por ejemplo, obras generales sobre procedimientos de formación de palabras en otras lenguas cercanas al español y que, por ello, contienen informaciones que son también comparativamente muy interesantes para nuestra lengua [p. ej., Grossmann, M., y F. Rainer (eds.) (2004): La formazione delle parole in italiano, Tubinga, Niemeyer]. De la misma manera, quedan fuera obras que se ocupan globalmente de diversos aspectos generales de la formación de palabras en las lenguas románicas y que, consecuentemente, contienen informaciones atingentes también al español [p. ej., LüDTKE, J. (2011): La formación de palabras en las lenguas románicas: su semántica en diacronía y sincronía, Méjico, El Colegio de México].

- Dejamos también al margen de nuestro inventario algunas obras que se han concebido más bien como manuales o libritos orienta- 
dos directamente para determinados estudiantes, normalmente universitarios, de países específicos [p. ej., Bartoš, L. y H. VALíková (2002): La formación de palabras en español, Brno, Filozofická Fakulta, Masarykovy Univerzity].

- Prescindimos también de aquellos trabajos centrados en exclusividad en un determinado tipo de procedimiento lexicogenético en español. Se trata de monografías, muchas de ellas de notable extensión, cuyo objeto de análisis es no el conjunto de procesos de formación de palabras sino un peculiar tipo formación. En las dos últimas décadas, han florecido monografías sobre casi todos los ámbitos de la lexicogénesis del español. Se acumulan así estudios sobre ámbitos tan significativos como son la verbalización [p. ej., Rifón, A. (1997): Pautas semánticas para la formación de verbos en español mediante sufijación, Universidad de Santiago de Compostela], la prefijación [p. ej., STEHLÍk, P. (2011): Aspectos problemáticos de la prefijación en español, Brno, Masarykova Univerzita] o la composición [p. ej., BuENAFUENTES DE LA MATA, C. (2010): La composición sintagmática en español, San Millán de la Cogolla, Cilengua; Moyna, M. ${ }^{a}$ I. (2011): Compound Words in Spanish (Theory and History), Ámsterdam/Philadelphia, John Benjamins]. Pero también se han desarrollado trabajos sobre fenómenos más marginales o tradicionalmente olvidados, como la parasíntesis [p. ej., Serrano-Dolader, D. (1995): Las formaciones parasintéticas en español, Madrid, Arco Libros] o la interfijación [p. ej., Martín CAMACHO, J. C. (2002): El problema lingüistico de los interfijos españoles, Cáceres, Servicio de Publicaciones, Universidad de Extremadura]. El carácter monográfico de todos estos trabajos permite desarrollar en ellos no solo una descripción de los fenómenos sometidos a examen sino una reflexión teórica bastante notable.

- No se incluyen tampoco específicamente tratados sobre neologismos en español aunque resulta evidente que en los trabajos sobre neología se recogen procedimientos de creación léxica. Salvo honrosas excepciones, muchos de estos trabajos tienen más interés por la acumulación de ejemplos variopintos que por suponer una aportación significativa al estudio de la morfología léxica española.

- En la medida en que nos centramos en una perspectiva descriptiva y sincrónica, dejamos fuera también estudios de marcado carácter histórico o dialectológico. 
Desbrozado el camino, podemos ya centrarnos en lo que consideramos estudios que pretenden ser abarcadores de todos los procedimientos de formación de palabras en español. Como se verá, hay diferencias muy notables entre ellos, no solo en extensión o en lo ajustado (o desajustado) de la descripción que ofrecen sobre la morfología léxica del español, sino también en el carácter mismo de esos trabajos y, muy fundamentalmente, en el tipo de público al que pretenden ir destinados y los consecuentes objetivos que se pretenden alcanzar. La presentación de estos tratados es cronológica y, como se verá, aunque están aquí reunidos bajo la común etiqueta de tratados globalizadores sobre la formación de palabras en español, algunos son más tratados que otros y algunos son más globalizadores que otros. En algunos casos, los propios títulos de las obras no describen de manera adecuada lo que en ellas verdaderamente se contiene. En suma, están todos los que son pero, quizás, no deberían ser todos los que están...

\section{Alemany Bolufer, J. (1920):}

Tratado de la formación de palabras en la lengua castellana, Madrid, Librería General de Victoriano Suárez

Como es bien conocido, el de Alemany es el estudio pionero sobre el conjunto de los procedimientos de formación de palabras en español. A pesar de su año de aparición no es, desde luego, un estudio de tipo histórico; hasta el punto que se ha seńalado que en realidad refleja un estado de conocimientos muy anterior al inicio del siglo xx en el que apareció. Carece quizás de una sistematicidad que sea morfológicamente relevante, agrupa los prefijos y sufijos por orden alfabético y, dentro de cada uno de ellos, diferencia las clases de palabras a las que se añaden y las que resultan de la afijación. Aunque presenta lagunas (e incluso errores), en su época tuvo el interés y el mérito de aplicar criterios predominantemente sincrónicos que permiten una descripción relativamente ordenada de los fenómenos sometidos a examen. Sin duda, esta obra ha sido ampliamente superada por tratados más recientes pero, no solo por su valor de época, sigue siendo hoy digna de ser consultada. Está disponible completa en versión electrónica gracias a la iniciativa de la Universidad de Toronto: http://www.archive. org/stream/tratadodelaforma00alemuoft\#page/200/mode/2up. 


\section{Narváez, R. A. (1970): An Outline of Spanish Morphology. Formation of Words, Inflectional and Derivational, St. Paul, Minnesota, EMC Corporation}

En 1970, en el vacío más absoluto de publicaciones sobre la cuestión, apareció esta sinopsis de morfología derivativa y compositiva del español (no exenta de errores de análisis) orientada hacia estudiantes universitarios americanos y hablantes nativos de lengua inglesa. Tuvo escasa repercusión en el ámbito hispánico. El mayor mérito del autor fue abordar globalmente la morfología léxica del español transcurridos ya 50 años desde la obra de Alemany, y hacerlo con ciertas pretensiones de exhaustividad en la recopilación de materiales: recoge más de 40 tipos de compuestos y más de 300 afijos derivativos (78 prefijos, 136 sufijos nominales, 99 sufijos adjetivos, 9 sufijos verbales y... i3 sufijos adverbiales!: -ante, (durar $>$ durante); -mente $($ cierta $>$ ciertamente) y $-s($ ante $>$ antes, cuesta $>$ a cuestas, quizá $>$ quizás $)$.

\section{Pilleux, M. (1983): Formación de palabras en español, Valdivia (Chile), Alborada}

A pesar de su título, este breve tratadito (apenas 100 páginas) se centra solo en la descripción de la sufijación espańola (recoge 131 sufijos). Pensado con fines didácticos, está dirigido a estudiantes de enseñanza básica, media y universitaria. Consta casi solo de listas de ejemplos para cada sufijo y no ofrece mayor atractivo.

\section{García Lozano, F. (1989): «Wortbildung», en N. Cartagena y H. M. Gauger, Vergleichende Grammatik Spanisch-Deutsch, Mannheim, Duden, vol. II: 73-330}

Muy extensa, ordenada e informativa resulta esta contribución de García Lozano. Durante muchos años ha sido el mejor tratamiento sobre la formación de palabras en una gramática sobre el español aunque, al enmarcarse en una gramática comparada del español y del alemán, no fue aprovechada como merecía por los estudiosos de morfología española. Es un estudio descriptivo y comparativo bastante completo: se describe sepa- 
radamente cada procedimiento lexicogenético en alemán y en español, y luego se contrastan. Resulta muy rico en datos y ejemplos, y contiene algunas reflexiones de notable interés.

5. Lang, M. F. (1990): Spanish Word Formation (Productive Derivational Morphology in the Modern Lexis), Londres, Routledge [Edición traducida y revisada: Formación de palabras en español. Morfología derivativa productiva en el léxico moderno, Madrid, Cátedra, 1992]

Aunque este manual incluye más fundamentación teórica que la mayoría de los precedentes (su primera parte consta de dos capítulos dedicados, respectivamente, a trazar el marco teórico e histórico y a presentar algunas recientes teorías de la morfología léxica), se resiente notablemente de no tener el autor al español como lengua materna. La obra está pensada también para un público no español y, en ocasiones, equipara en importancia formaciones totalmente generalizadas, regulares y productivas con otras marginales, lúdicas e incluso extrañas a la configuración morfológica del español. Curiosamente, ha sido un manual más usado y citado que otros que resultan más ajustados en sus análisis. Su rápida traducción al español es prueba palmaria de la necesidad que había en el ámbito hispano de una obra de este género. Su mayor valor es precisamente el haber roto el fuego de las publicaciones globalizadoras sobre lexicogénesis del español en la década de los noventa del siglo xx. Sin negar lo oportuno de la obra, tiene algunas carencias notables en los análisis propuestos.

\section{Thiele, J. (1992): Wortbildung der spanischen Gegenwartssprache, Leipzig, Langenscheidt}

El libro se dirige fundamentalmente a docentes y estudiantes de hispanística. Es un interesante tratado que está estructurado de modo claro, coherente, muy lúcido y original: cada capítulo se dedica a una clase de palabras (sustantivo, adjetivo, verbo...) y, dentro de ella, diferencia los diversos tipos de procedimientos de formación de palabras que pueden observarse (por ejemplo, en el capítulo dedicado al sustantivo, estudia sepa- 
radamente cómo se puede producir la nominalización: sufijación, prefijación, reducción, composición, acortamiento y conversión). En su parte final, el trabajo contiene algunos cuadros generales con resúmenes muy informativos y bien elaborados. La validez del libro de Thiele y su idioma de redacción habrían merecido su traducción al español (curiosamente, su año de publicación coincide con el de la traducción española de la obra de Lang, cuyo atractivo es mucho menor). El libro no tuvo en España la difusión que merecía.

7. González Ollé, F., y M. Casado Velarde (1992): «Spanisch: Wortbildungslehre. Formación de palabras», en G. Holtus, M. Metzeltin y C. Schmitt (coords.), Lexikon der Romanistischen Linguistik (LRL), VI.1, Tubinga, Niemeyer: 91-109

Brevísima sinopsis de los procedimientos de creación léxica del español. Bien elaborada pero muy sucinta, de modo que apenas resulta hoy operativa ante la avalancha de publicaciones de conjunto y de acertados resúmenes sobre los procesos de la morfología léxica del español.

\section{Alvar Ezquerra, M. (1993): La formación de palabras en español, Madrid, Arco Libros, (7. ${ }^{\mathrm{a}}$ ed., 2008)}

Breve manual (80 páginas) de carácter evidentemente didáctico que aparece dentro de la colección "Cuadernos de Lengua Española», bien conocida por su valor práctico para los alumnos (y profesores) en los años previos a la universidad y en los primeros cursos universitarios. Las varias reediciones de la obrita dejan bien a las claras la utilidad del estudio, tan sencillo en sus contenidos como bien elaborado para alcanzar los objetivos buscados. Resulta evidente, sin embargo, que no puede incluir (ni lo pretendía) un estudio de conjunto de mediano calado. Como se reconoce en su introducción, no se trata en profundidad ninguna de las materias consideradas, aunque se ha procurado llegar a todos los rincones. El trabajo se cierra con una treintena de breves ejercicios prácticos y de reflexión (con sus correspondientes soluciones). 


\section{RaIneR, F. (1993): Spanische Wortbildungslehre, Tubinga, Niemeyer}

Es el tratado de formación de palabras sobre el español más extenso, plural y ambicioso redactado hasta hoy. Destaca por su magnitud y por las completas y, por lo general, acertadas descripciones que contiene sobre todos los procedimientos lexicogenéticos del español. Sin duda, es -y continuará siendo durante muchos años- el intento más generoso de abordar en profundidad (y con una sorprendente riqueza de materiales) los procedimientos de formación de palabras en español. A la presentación e interpretación de materiales léxicos del castellano se une la explícita preocupación por la fundamentación teórica de algunas cuestiones generales de la Wortbildung. De la amplitud del proyecto derivan inexcusablemente ventajas (el volumen de materiales y temas sometidos a examen) e inconvenientes (la imposibilidad de profundizar en el análisis de algunos problemas, que quedan simplemente apuntados). Además, el libro se cierra con una extensa y actualizada bibliografía (hasta 1993). Es la mejor y más completa presentación descriptiva de la lexicogénesis del español, no exenta de tomas de postura teóricas y metodológicas que, como tales, pueden resultar a veces criticables. Puede verse una valoración más pormenorizada del libro en una reseńa nuestra aparecida en Vox Romanica, 53 (1994): 410-420.

\section{Varela, S. (ed.) (1993): La formación de palabras, Madrid, Taurus}

Interesante recopilación de artículos de diversos autores editada por Soledad Varela. Aunque no es propiamente una obra de conjunto, sí incluye - además de un capítulo de estado de la cuestión y otro de selección bibliográfica comentada - trabajos sobre variadas facetas de la formación de palabras en español — desde una perspectiva sincrónica- - y sobre su relevancia para la morfología teórica en general. Los artículos coinciden en su objeto de estudio (no así en las teorías o los métodos seguidos) y ofrecen una muestra no exhaustiva pero sí variada de diversos procedimientos morfológicos: derivación y composición nominal, derivación verbal y adverbial, afijación apreciativa, interfijación y parasíntesis. 


\section{Miranda, J. A. (1994): La formación de palabras en español, Salamanca, Ediciones Colegio de España}

El libro ofrece una sistemática presentación descriptiva de los procedimientos lexicogenéticos del español. Está destinado, fundamentalmente, a estudiantes de lengua española (extranjeros y de primer ciclo de universidad). Su correcta sistematización y su riqueza de ejemplos lo hacen, sin duda, didácticamente útil aunque son escasos los ejercicios prácticos que incluye (con sus correspondientes claves). El libro, dentro de los objetivos que persigue, está correctamente elaborado y coherentemente estructurado, si bien cuenta con la circunstancia desfavorable de haber aparecido en una editorial modesta.

\section{Almela Pérez, R. (1999): Procedimientos de formación de palabras en español, Barcelona, Ariel}

Monografía general sobre los diversos procedimientos de formación de palabras en español, bien elaborada, con una correcta sistematización y con explicaciones claras. Obra de conjunto bastante completa en la que se describen los diversos procedimientos lexicogenéticos y se hace una revisión crítica sucinta del tratamiento de cada uno de ellos. Pretendía llenar un hueco que, a pesar de los intentos previos, permanecía todavía, si no vacío, sí abierto. Hoy en día, y como obra fundamentalmente descriptiva, se ha convertido — junto con la obra de S. Varela de 2005 a la que luego nos referiremos- en uno de los manuales de estudio de asignaturas universitarias sobre formación de palabras. En el ámbito hispanohablante, es hoy uno de los tratados de referencia más ajustados. Puede verse una valoración más detallada del libro en nuestra reseña aparecida en Verba, 28 (2001): 407-421.

\section{Bosque, I., y V. Demonte (dirs.) (1999): Gramática descriptiva de la lengua española, Madrid, Real Academia Española, Espasa-Calpe (Colección Nebrija y Bello)}

Sin duda, es esta una de las más ambiciosas y dilatadas empresas de descripción del español llevadas a cabo en los últimos siglos. En contra 
de lo habitual en las gramáticas del español, la obra dedica amplio espacio al tratamiento de diversos aspectos de la formación de palabras. En este sentido, puede afirmarse que es el punto de partida clave para la definitiva incorporación del ámbito morfológico en las descripciones gramaticales del español con pleno derecho y reconocida carta de naturaleza. La "Quinta Parte: Morfología» incluye 11 extensos capítulos consagrados a la exhaustiva descripción de los procesos de morfología léxica en español:

- Capítulo 66. J. Pena: «Partes de la morfología. Las unidades del análisis morfológico».

- Capítulo 67. C. Piera y S. Varela: «Relaciones entre morfología y sintaxis».

- Capítulo 68. C. Pensado: «Morfología y fonología. Fenómenos morfofonológicos».

- Capítulo 69. R. Santiago Lacuesta y E. Bustos Gisbert: «La derivación nominal».

- Capítulo 70. F. Rainer: «La derivación adjetival».

- Capítulo 71. F. A. Lázaro Mora: «La derivación apreciativa».

- Capítulo 72. D. Serrano-Dolader: «La derivación verbal y la parasíntesis».

— Capítulo 73. J. Francisco Val Álvaro: «La composición».

— Capítulo 76. S. Varela y J. Martín García: «La prefijación».

— Capítulo 77. J. Portolés: «La interfijación».

- Capítulo 78. M. Casado Velarde: «Otros procesos morfológicos: acortamientos, formación de siglas y acrónimos».

Estos capítulos dedicados a morfología léxica gozan de una cierta uniformidad — quizás mayor que la conseguida en otras partes de la Gramática - en el tratamiento de los diversos procedimientos lexicogenéticos sometidos a examen y suponen un tratamiento ciertamente exhaustivo de los temas abordados. Desde su aparición, los diversos capítulos se han convertido en referencia inexcusable para aquellos estudiosos que han pretendido profundizar en aspectos específicos de la descripción o del análisis del componente morfológico léxico del español. 


\section{Jover, G. (1999): Formación de palabras en español (Curiosidad por el lenguaje), Barcelona, Octaedro}

Este librito presenta como objetivo expreso tratar de despertar una cierta curiosidad por el lenguaje en jóvenes de 14 o 15 años aunque, sin género de dudas, también puede resultar útil en la línea de aprendizaje del español como lengua extranjera. Presenta la peculiaridad de que está aligerado de carga teórica y de que contiene muchos ejemplos, artículos de prensa, dibujos, ejercicios y textos que pueden ser aprovechables directamente en la clase. Es este un trabajo muy singular en su género y, dentro de los claros límites que se fija, ciertamente de un enorme interés para favorecer un primer contacto con los procesos lexicogenéticos del español, los cuales suelen aparecer de modo disperso y torpe en los manuales escolares.

\section{Pérez Cino, W. (2002): Manual práctico de formación de palabras en español, vol. I, Madrid, Verbum}

En el año 2002 apareció el primer volumen de esta obrita (que no ha tenido continuidad desde entonces aunque se anunciaba un segundo volumen en el que se pretendía tener en cuenta factores que presupondrían un mayor conocimiento de la lengua). Es un monográfico que, desde una perspectiva eminentemente práctica, se dirige a los estudiantes de E/LE de niveles elemental y medio. Prescindiendo de complejas terminologías lingüísticas, se presentan grupos de prefijos, de sufijos y de formaciones compuestas acompañados de ejercicios no contextualizados y de corte muy tradicional.

16. Santana Suárez, O., F. J. Carreras Riudavets y J. R. Pérez Aguiar (2004-2006): Relaciones morfoléxicas sufijales para el procesamiento del lenguaje natural (2004), Relaciones morfoléxicas prefijales para el procesamiento del lenguaje natural (2005), Relaciones morfoléxicas parasintéticas para el procesamiento del lenguaje natural (2006), Madrid, Mileto 
En los años 2004-2006 se publicaron estas tres peculiares obras, dedicadas respectivamente a la sufijación, a la prefijación y a la parasíntesis del español (por lo que configuran, con la excepción de la composición, un estudio global de los procedimientos de creación léxica). Lo que se pretende en última instancia es obtener un conjunto de relaciones morfoléxicas (sufijales, prefijales y parasintéticas) entre las palabras del español y automatizarlas adecuadamente para que puedan ser tratadas en aplicaciones de procesamiento automático del lenguaje natural. Son estudios con la mirada puesta en el análisis automatizado de la morfología, de modo que los aspectos formales (e incluso teóricos) que en ellos se presentan no tienen por qué coincidir estrictamente con los de una descripción morfológicolingüística afinada.

\section{Varela Ortega, S. (2005): Morfología léxica: la formación de palabras, Madrid, Gredos (Colección "Enseñanza y lengua española»)}

Sucinta, básica y clara descripción de los procedimientos de formación de palabras en español que destaca por la ordenada presentación y tratamiento de los fenómenos descritos. No obstante, la auténtica eclosión de estudios de conjunto sobre los procedimientos lexicogenéticos del español que se ha producido en los últimos ańos, esta obra llena un hueco que era necesario y urgente completar. A pesar de la sencillez del manual, en él no se elude el tratamiento de algunos de los aspectos más complejos y controvertidos de algunos procesos morfológicos. Mérito indudable es lograr acomodar las necesarias explicaciones que exigen fenómenos de una cierta dificultad analítica a un nivel de simplicidad argumental —exigido por el tipo de público al que se dirige la obra - francamente plausible. Mención especial merecen los ejercicios prácticos y de reflexión que cierran cada uno de los capítulos, hasta el punto de que es el mejor compendio de ejercicios específicamente dedicados a la formación de palabras en español existente hasta la fecha.

18. Felíu Arquiola, E. (2009):

«Palabras con estructura interna», en E. de Miguel (ed.), Panorama de la lexicologia, Barcelona, Ariel: 51-82 
Se ocupa, desde la perspectiva de la morfología léxica, del conjunto de procedimientos formales empleados en español para crear, partiendo de unidades léxicas preexistentes, palabras nuevas que presentan una estructura interna más compleja que la de aquellas sobre las que se forman. Se subraya el carácter estructurado, dinámico y creativo del lexicón; y la autora se centra en el ámbito propiamente morfológico de la creación léxica. A pesar del obligado carácter descriptivo que domina el capítulo, no se desdeña plantear cuestiones polémicas: contraste entre morfología léxica y morfología flexiva, restricciones a las que se someten las reglas de formación de palabras, paradojas de encorchetado, delimitación entre prefijación y composición, problemas que plantea la parasíntesis...

\section{RAE (2009): Nueva gramática de la lengua española, Madrid, Real Academia Española y Espasa}

Estamos ante la más extensa y pormenorizada de las gramáticas académicas hasta ahora publicadas y la primera que otorga a la morfología léxica el papel cuantitativo y cualitativo que merece en una amplia descripción del español. A lo largo de 450 páginas se intenta ofrecer una descripción exhaustiva de los diversos procedimientos lexicogenéticos del español teniendo en cuenta facetas muy diversas: aspectos morfofonológicos, informaciones semánticas, peculiaridades formales, variantes dialectales, analogías y diferencias, alternancias afijales, dobletes morfológicos, incidencia de las perspectivas sincrónica y diacrónica en la interpretación de la estructura morfológica... Son siete los capítulos dedicados al tema:

- Capítulo 5. «La derivación nominal (I). Nombres de acción y efecto".

- Capítulo 6. «La derivación nominal (II). Otros derivados».

- Capítulo 7. «La derivación adjetival y adverbial».

- Capítulo 8. «La derivación verbal. La parasíntesis».

- Capítulo 9. «La derivación apreciativa».

- Capítulo 10. «La prefijación».

- Capítulo 11. «La composición».

La cantidad de fenómenos morfológicos sometidos a examen - y las propias limitaciones de una gramática académica, que no aspira a sustituir 
a monografías especializadas para temas concretos - trae consigo que los planteamientos presentados para determinados procesos morfológicos o las tomas de postura sobre la correcta interpretación de ciertas estructuras morfológicas puedan ser, en ocasiones, discutibles. No obstante es, obviamente, el tratamiento más reciente y pormenorizado de los procedimientos de creación léxica en español y, por ello, base inexcusable de cualquier acercamiento lingüístico a los mismos.

\section{Apéndice: revisiones y repertorios bibliográficos sobre formación de palabras en español}

Como puede deducirse del breve panorama esbozado en esta contribución, hace ya algunos años que la morfología léxica ha dejado de ser la pariente pobre de la lingüística española. El escaso interés que el tema de la formación de palabras suscitó en Menéndez Pidal fue decisivo para la cuasi nula atención que al mismo dedicaron sus discípulos y, en general, la investigación filológica española durante muchos años. La situación, por suerte - y por justicia-, ha ido cambiando notablemente. Basta consultar los repertorios bibliográficos de Bosque y Mayoral (1979), de Rainer (1993) o de García-Medall (1995) para darse cuenta de que es en los últimos decenios cuando ha (re)surgido el interés por estos temas. Y con las obras y artículos aparecidos desde 1994 (ańo en que se cierra el último de los repertorios bibliográficos citados) podría muy bien hacerse uno nuevo de considerable volumen: la bibliografía de García Medall (1995) recogía, para 1900-1994, unas 1300 referencias bibliográficas... pero el propio García Medall (según avisa en una publicación posterior), recogió, desde 1994 hasta 2002, casi 700 nuevas referencias sobre el tema. Y en los últimos años, suma y sigue. A falta de una actualizada y completa guía bibliográfica sobre los procedimientos de creación léxica en español — que hoy en día solo tiene sentido concebida como documento en red permanentemente renovado y puesto al día-, finiquitamos nuestra tarea listando algunos repertorios bibliográficos que pueden resultar de utilidad. A ellos unimos también dos breves pero sagaces revisiones sobre el estado de la cuestión bibliográfica en este campo que abarcan desde 1970 hasta 2003 (nos referimos a Varela Ortega 2000 y a Pena 2003), así como la reciente revisión bibliográfica — que comprende desde 1999 hasta 2009- propuesta en Pazó, Gil y Cano (2011). 


\section{Referencias (por orden cronológico)}

Sandru-Olteanu, T. (1972): «Bibliografía de los trabajos relativos a la formación de palabras en los idiomas iberorrománicos (1920-1970)», Boletín de Filología Española, 42-45: 13-35.

BosQue, I., y J. A. MaYoral (1979): «Formación de palabras. Ensayo bibliográfico», tirada aparte de los Cuadernos Bibliográficos, 38.

RAINER, F. (1993): «Setenta años (1921-1990) de investigación en la formación de palabras del español moderno: bibliografía crítica selectiva», en S. Varela (ed.), La formación de palabras, Madrid, Taurus: 30-70.

García-Medall, J. (1995): Casi un siglo de formación de palabras del español (1900-1994). Guía bibliográfica, Valencia, Universidad de Valencia.

Varela Ortega, S. (2000): «25 años de morfología española: la formación de palabras (1970-1995)», en M. Bargalló y C. Garriga (eds.), 25 años de investigación en la lengua española, Tarragona, Universitat Rovira i Virgili: 81-110.

GonzÁlez Aranda, Y. (2002): Lexicología y lexicografía del español. Repertorio bibliográfico (1990-2002), Almería, Servicio de Publicaciones y Universidad de Almería.

Díaz Hormigo, M. a T. (2003): Morfología, Cádiz, Servicio de Publicaciones y Universidad de Cádiz: 276-332.

Pena, J. (2003): «Los estudios de morfología del español en España durante los últimos 25 años (1979-2003)», Lingüistica Española Actual (LEA), XXV/1 y 2: 7-38.

Serrano-Dolader, D. (2009): «La morfología léxica y el español como lengua extranjera (selección bibliográfica comentada)», en D. Serrano-Dolader, M. ${ }^{a}$ A. Martín Zorraquino y J. F. Val Álvaro (eds.), Morfología y español como lengua extranjera (E/LE), Zaragoza, Prensas Universitarias de Zaragoza 177-195.

PAzÓ, J., I. Gil y M. a Á. CANo (2011): «Diez años de teoría morfológica en España», en J. Pazó, I. Gil y M. a Á. Cano (eds.), Teoría morfológica y morfología del español, Madrid, Servicio de Publicaciones de la Universidad Autónoma de Madrid: 19-58. 



\title{
ASPECTOS DE LA SUFIJACIÓN EN ESPAÑOL ${ }^{1}$
}

\author{
Félix Tadeo Monge Casao \\ (Universidad de Zaragoza)
}

Todos o casi todos ustedes saben que la formación de las palabras ha sido durante muchos años la Cenicienta de los estudios sobre lingüística española. En 1920 se publica el libro de José Alemany Bolufer Tratado de la formación de palabras en la lengua castellana, que refleja en realidad un estado de conocimientos muy anterior. Falta toda preocupación histórica y sistemática. Agrupa los sufijos por orden alfabético, y dentro de cada uno de ellos distingue las diferentes clases de palabras a que se añaden y las clases de palabras que resultan. Es un trabajo que podría haberse escrito perfectamente antes del siglo xIx. Para el lingüista de hoy, y a pesar de sus errores y lagunas, tiene el interés de aplicar un criterio predominantemente sincrónico. Coincide, pues, con la moda lingüística de nuestros días, y es lástima que sea tan poco utilizado. Su lectura puede deparar muchas sorpresas. Recomiendo su lectura vivamente, a pesar de ser obra resueltamente anticuada.

El poco interés que suscitó en Menéndez Pidal el campo de la formación de palabras, patente en la poca extensión que le dedica, tanto en el Manual de gramática histórica española como en el volumen de Gramática en su edición del Cantar del Cid, como en Orígenes del español, fue deter-

1 Reproducimos, con el permiso correspondiente, el artículo ya publicado en Revista Española de Lingüistica, 26.1 (1996): 43-56. 
minante, me parece, para la poca atención que posteriormente le dedicó su escuela y, en general, la investigación filológica española.

Un botón de muestra. Cuando en los años cincuenta se montó el plan de una Enciclopedia Lingüistica Hispánica, en seis o siete volúmenes (a tenor del único publicado, con más de quinientas páginas cada uno), a Cargo de Manuel Alvar, Antonio Badía, Rafael de Balbín y el portugués Lindley Cintra y publicado por el Consejo Superior de Investigaciones Científicas, se me invitó a redactar el apartado sobre formación de palabras. Y se me concedió para ello una extensión máxima de treinta páginas (quizá fueron cuarenta: no me acuerdo bien después de tantos años, pero, desde luego, no más de cuarenta).

Si comparan ustedes el caso con la Gramática de las lenguas romances de W. Meyer-Lübke, que de los cuatro volúmenes de que consta (o, si quieren ustedes, tres y medio, ya que la segunda mitad del cuarto volumen consiste únicamente en índices), dedica medio volumen a la formación léxica, el contraste resulta bien llamativo. Y la Grammaire historique de la langue française, de Nyrop, en seis volúmenes, dedica un volumen entero a la formación de las palabras.

Antes de 1920, habían aparecido (no aprovechadas o no bien aprovechadas por Alemany) la Gramática histórica de la lengua castellana (1913), de F. Hanssen, con un extenso capítulo sobre formación léxica, y las Apuntaciones criticas sobre el lenguaje bogotano, de R. J. Cuervo que, al ocuparse de estos problemas en el español americano, ofrece también abundantes y valiosísimas observaciones referentes a la lengua general. Leo Spitzer publicó también alguna contribución importante, y G. Sachs se ocupó brevemente de la formación de los gentilicios. Todos estos estudios eran, como correspondía a la época, de orientación historicista.

En 1935, publicó Amado Alonso su estudio clásico, de carácter estilístico, sobre los diminutivos españoles. Y en 1943 y 1944, aparecen en la ZRPh los «Ibero-romanische Suffixstudiem» de M. L. Wagner, en donde se ocupa de varios sufijos con apreciable aportación de datos dialectales y americanos. Rohlfs y otros estudiosos (los españoles en minoría) dedican trabajos monográficos a algunos prefijos y sufijos espańoles. En los diversos estudios sobre hablas locales se va dedicando una atención creciente a la formación de las palabras. 
Y, lo más importante, la abundante y eruditísima producción de Y. Malkiel, que dedica trabajos particulares a varios sufijos pero, sobre todo, una atención vigilante hacia todos los problemas relacionados con la formación de las palabras. En la mayor parte de sus trabajos hay alusiones y desarrollos referentes a este campo, apoyadas siempre en una sólida - a veces podría decirse abrumadora- documentación. El DCEC de J. Corominas - y, claro está, el Corominas-Pascual — es fundamental por ofrecer la fechación de muchos derivados. Y lo mismo, y por parecida razón, el Tesoro lexicográfico de S. Gili Gaya, desgraciadamente incompleto. El $D H L E$ de la $R A E$, en la pequeña parte publicada, es, por supuesto, imprescindible. Para el español de América, continúa siendo útil, aunque haya sido superado, el Cuestionario lingüístico hispano - americano (1943) de Tomás Navarro Tomás.

La investigación y el conocimiento fueron después mejorando, pero es lo cierto que en otras lenguas románicas, sobre todo en francés, la investigación y el conocimiento estaban mucho más avanzados. España estuvo muchos años casi a la cola de las lenguas romances en lo que al estudio de la formación léxica se refiere.

Hay que decir, por último, que se aprecia un interés renovado por la formación léxica entre los lingüistas españoles jóvenes (jjóvenes para mí!: voy a citar nombres de personas de alrededor de cuarenta y cincuenta años). Estoy pensando en Ignacio Bosque, Lázaro Mora, Martínez Celdrán, Pena Seijas, Hernán Urrutia, Soledad Varela, Vera Luján, etc. Y hoy, en definitiva, puede decirse que la formación léxica es un ámbito que está de moda. Quizá, al menos en parte, por lo poco atendida que estuvo antes.

En 1990, aparecen dos libros sobre este campo:

Varela Ortega, Soledad, Fundamentos de morfología, Madrid, Síntesis, que, independientemente del título, dedica atención preferente a la formación léxica. Es de orientación generativista, y atiende más a la teoría que a la aportación de materiales;

Lang, M. F., Spanish Word Formation, Routledge, Londres-Nueva York (traducción espańola en Cátedra 1992). Tiene más aportación de materiales, pero menos entidad teórica, y se resiente de no tener el autor el español como lengua materna. 
En 1992 aparece el librito, resueltamente modesto, pero con indudables méritos, J. Thiele, Wortbildung der Spanischen Gegenwartssprache, Langenscheidt Verlag Enzyklopedie Leipzig, Berlín, Múnich. Mucho más importante es Rainer, Franz, Spanische Wortbildungslehre, Tubinga, Max Niemeyer Verlag, 1993. Es un grueso volumen de 800 apretadas páginas y riquísima aportación de materiales que llena el gravísimo vacío existente hasta ahora de no disponer de una obra de conjunto sobre la formación de palabras en español. Estos últimos trabajos son, en general, de orientación generativista. La exposición que van a leer no tiene tal carácter. La verdad es que no soy muy ducho en gramática generativa, ni pienso que sea la doctrina más aconsejable. Por eso me ha parecido mejor presentarles algunos aspectos y problemas que plantea la sufijación en español, limitándome a una descripción, por fuerza, sucinta.

¿De qué se ocupa el estudio de la formación de las palabras?

Según Meyer-Lübke en su gramática histórica de la lengua francesa (vol. II, pág. 2): «Su objeto consiste en el estudio de los medios de que se sirve una lengua para enriquecer su vocabulario dentro de su propio sistema y sin recurrir a préstamos y del influjo de estos procedimientos de formación léxica en la significación de la palabra».

Dentro del ámbito del significado conviene hacer una distinción previa (debida a Pichon, 1942), entre vocablos «nativos» y vocablos «adultos» (distinción no apoyada en criterios cronológicos, sino semánticos).

Los vocablos nativos dependen todavía por su significación, de modo total, de la palabra de que han sido formados (y lo que permite reconocerlos es sobre todo el sentimiento lingüístico, en cuanto el derivado parece estrechamente dependiente de su base léxica). Es lo que ocurre, por ejemplo, con las parejas blanco/blancura, rendir/rendición, o zapato/zapatero.

Los vocablos adultos son aquellos en los que ha habido ya una especialización semántica o, en términos de Pichon, una «diferenciación secundaria». Sería el caso, por ejemplo, de cerradura o embutido, originariamente con sentido de acción y hoy con sentidos concretos en sus acepciones más usuales. Advierte Pichon que lo más frecuente es la conservación del sentido original junto a los especializados. Cuenta conserva hoy el sentido originario de acción, pero tiene también otros: sin duda, no son lo mismo las cuentas del rosario que las cuentas aritméticas, ni ambas, a su vez, que las cuentas de los restaurantes. 
Se forman palabras nuevas a partir de vocablos ya existentes por procedimientos de filiación léxica definidos. Es fundamental para nuestra consideración el saber si un procedimiento (o un elemento) de enriquecimiento está vivo o no. Está vivo cuando su valor semántico está lo bastante presente en el espíritu de los hablantes para que a cada instante puedan formarse nuevos términos por este medio. Es el problema general de la vitalidad de cada uno de los procedimientos (o elementos) de formación de las palabras.

Desde este punto de vista (el de la vitalidad), y especialmente en la sufijación, hay que distinguir - y es otra distinción de Pichon- entre una formación "espontánea» y otra «fabricada». Hay derivación «fabricada» cuando un técnico, de modo consciente, da un nombre a una noción científicamente individualizada. Así, cloroso, sulfoso, frente a clórico, sulfúrico. Es un modo de formación que no se apoya en el sentimiento lingüístico colectivo, y el resultado son vocablos adultos congénitos (incluso se les define para que tengan sentido).

La auténtica derivación es la espontánea, la que nace por necesidades generales de la expresión. Es además, con mucho, la más frecuente: barato/ abaratarlabaratamiento, Ilorar/llorón, cantar/canturrear, dormirldormitar, etc. En la formación espontánea el vocablo nuevo tiene, al menos inicialmente, el carácter de nativo. Su significado resulta de la adición del sentido de la base léxica y del valor vivo propio del formante. Y siendo el formante vivo, es decir, con un valor de captación inmediata por el hablante, está asegurada la inteligibilidad sin necesidad de definición previa. Después, pero solo después, pueden tener lugar los procesos de especialización semántica.

Hay, sin embargo, excepciones. Durante el descubrimiento y colonización de América se encontraron los españoles animales, vegetales y minerales desconocidos para ellos. En multitud de casos les dieron nombre añadiendo un sufijo al de la realidad europea que les parecía más próxima o semejante. Es el caso, p. ej., de platina (para designar al mineral platino, relacionándolo con plata) y de otros muchos. Fue una suerte de formación fabricada (y al mismo tiempo espontánea) con sufijos vivos en la lengua general, y las palabras resultantes fueron, claro está, adultas desde su nacimiento.

Puede ocurrir también que un sufijo de la lengua científica llegue a ser empleado en el habla común (generalmente son formaciones efímeras, coloquiales y de carácter humorístico). Así, el sufijo -itis, de origen 
griego y muy utilizado en la terminología médica (bronquitis, encefalitis, pleuritis), ha dado lugar a buen número de formaciones humorísticas (Beinhauer: holgazanitís, seguritis; Wagner: los americanismos arranquitis, cruditis, mieditis —esta también conocida en el español peninsular-; y yo mismo he oído a una seńora quejarse de padecer rositis, refiriéndose al hastío y molestia que le producía otra, llamada Rosa). Pueden verse más ejemplos de imitaciones humorísticas de la terminología técnica en Beinhauer, ob. cit.

La sufijación es uno de los procedimientos de que se sirve la lengua para enriquecer su vocabulario sin recurrir a préstamos: es, pues, procedimiento de formación de palabras.

Aparte de otros, hay que estudiar dos aspectos fundamentales:

a) el de la forma de los elementos de la nueva palabra (sobre todo las modificaciones que sufren la base léxica y el sufijo al unirse).

b) la significación y función del elemento sufijal añadido y del conjunto resultante.

A veces, en diacronía, no es fácil separar la sufijación de la composición. Buenamente, es hoy un adverbio con el sufijo -mente, pero hace 800 años era un procedimiento compositivo, y hace 1000 una construcción sintáctica. Pero claro que esto no es pertinente en la descripción.

La sufijación consiste así en añadir una secuencia fónica llamada sufijo al radical de un vocablo ya existente.

Desde un punto de vista estrictamente sincrónico puede considerarse que radical y sufijo representan en cierto modo un sintagma de dos elementos, en el que el sufijo tendría a su cargo modificar (¿orientar?) la significación del concepto nuclear.

Si tomamos como ejemplo una familia de palabras no muy abundante - la de ojo- y teniendo en cuenta solamente algunas de sus formaciones, se dibujan varias líneas de derivación:

Sobre ojal, 'hendedura para sujetar un botón', se forman al menos ojalador (-a), 'persona que hace ojales', y ojaladura, 'conjunto de ojales de un vestido'; Ojear tiene al menos dos acepciones: a) 'dirigir los ojos o mirar a determinada parte' y b) 'espantar la caza con ruidos'. 
Y sobre ojear, ojeada, 'acción' (ac. a), ojeador, 'persona' (ac. b), ojeo, 'acción' (ac. b).

Sobre ojera, 'coloración cárdena alrededor del párpado inferior', se forman ojeriza 'odio o mala voluntad contra uno', y ojeroso, 'que tiene ojeras'.

ojete es 'ojal redondo', y ojoso, 'que tiene muchos ojos o agujeros, como el pan, el queso', etc.

Imaginen ustedes lo que pasa en otras familias de palabras más abundantes (es fácil comprobarlo acudiendo al Diccionario ideológico, de Julio Casares).

Uno de los objetos fundamentales del estudio habrá de ser, precisamente, examinar la acepción y variabilidad semántica que se produce al añadir un sufijo a una base léxica determinada.

Por otra parte, para Bally ( $\$ 184)$, el sufijo, en general, indica en qué categoría nueva entra tal o cual lexema — que toma entonces la forma de un radical- y tiene por función especificar, determinar, esta categoría, como la especie determina al género:

trabajador: 'hombre - que trabaja'.

firmemente: 'de una manera (modo) - firme'.

Así pues, especifica, determina, la categoría en que se inscribe la nueva formación.

Ahora bien, si aceptamos las ideas de Bally ( $\$ 174 \mathrm{~B})$, las palabras sufijadas equivalen a un sintagma de rección en el cual el sufijo es el elemento determinado:

tintero $=$ 'Objeto - para la tinta'.

reglamentación = 'acción de - reglamentar'.

zapatero = 'el que hace, arregla - zapatos'.

O, como dice en otro lugar ( $\$ 387)$, las palabras sufijadas son sintagmas de secuencia regresiva, ya que el sufijo designa una idea general y categorial, determinada por el radical que precede:

llorón = 'el que (-ón) llora'.

cantador = 'el que (-dor) canta'. 
aterrizaje = 'acción de (-aje) aterrizar'.

arenoso $=$ 'que tiene (-oso) arena'.

claramente = 'de una manera, modo (-mente) claro'.

Gráficamente:

llor-rón

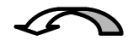

aren-oso, etc.

Así pues, los sufijos:

a) modifican la significación del radical: tinta / tintero;

b) son susceptibles de cambiar la clase de la palabra a que se ańaden: llorar / llorón (es decir, son determinantes desde el punto de vista categorial);

c) son determinados desde el punto de vista sintagmático: 'Ilorón = el que (-ón) llora'.

Todo esto es cierto para la gran mayoría de los sufijos. Pero hay un grupo importantísimo que presenta caracteres diferentes. Me refiero a los sufijos «apreciativos» (diminutivos, aumentativos, peyorativos).

¿Cuáles son sus caracteres?

a) Modifican el significado del primitivo, sí, pero solo de un modo cuantitativo (grande, pequeño) o cualitativo (agradable, desagradable, etc.). Es decir, que no resulta una significación nueva para designar una realidad o un concepto diferentes.

Existen, por supuesto, lexicalizaciones, formaciones (sobre todo en -illo, -illa) que han llegado a adquirir sentidos independientes (tomillo, colilla, gargantilla), pero entonces son palabras nuevas, y los sufijos no son ya sufijos apreciativos.

b) No modifican la clase de la palabra a que se ańaden (casa/casita, hombre /hombracho). Es decir, que no son determinantes desde el punto de vista categorial. Existen lexicalizaciones con aparente base verbal (dobladillo, picadillo, mezclilla), pero no contradicen esta afirmación, ya que en su mayor parte se trata de formaciones sobre nombres (así, existen o han existido doblado, picado, mezcla, con sentido idéntico o muy próximo). Y en todo caso, insisto, se 
trata ya de lexicalizaciones, formaciones, pues, que se han evadido del marco de la sufijación apreciativa.

c) No son determinados desde el punto de vista sintagmático, y no son sintagmas de secuencia regresiva.

Frente al caso general:

tintero $=$ 'objeto (ero) para la tinta'.

En los apreciativos:

casita $=$ 'casa pequeña (-ita)'.

caballejo = 'caballo de poco valor (-ejo)'.

Está, pues, claro que los apreciativos forman grupo aparte de los demás sufijos.

Advertíamos antes que un aspecto fundamental del estudio de la formación de las palabras era el de la vitalidad respectiva de los medios de enriquecimiento léxico, y que un medio de enriquecimiento léxico - procedimiento o formante- está vivo cuando su valor semántico está lo bastante presente en el espíritu del hablante para que a cada instante puedan formarse nuevos términos por este medio.

Así, p. ej., es sabido que, en español actual, tiene acusada vitalidad el esquema V + N. Para calificar a alguien de ser persona de poca importancia (un don nadie), se empleaban hace un siglo:

metesillas

pinchapeces

pinchauvas

tuercebotas

Nada menos que cuatro términos (¡y hubo otros!) para un mismo concepto. Como se podría comprobar también con otros ejemplos (p. ej., matasanos), la vitalidad del esquema $\mathrm{V}+\mathrm{N}$ se da sobre todo en la lengua de hoy en calificaciones con carga afectiva y con una cantidad variable de operación imaginativa o fantasística.

Ocurrió lo propio con tres denominaciones - frase del mundo automovilístico en los años posteriores a nuestra Guerra Civil. En ellas no se llegó a la unión en una palabra, pero ilustran especialmente porque nos muestran el inicio del procedimiento: 
(el) ahi te pudras (asientos traseros fuera de la capota en el Citroën dos plazas).

(un) vas o (u) vienes (Studebaker, 1946).

(un) quiero y no puedo (Biscúter).

No se precisan muchas aclaraciones si se piensa en que los ocupantes de los asientos traseros del coche Citroën iban a la intemperie, sin protección, que el modelo Studebaker 1946 tenía forma semejante por delante y por detrás, y que el Biscúter era vehículo más que modesto, además de bastante utilizado en los ańos cuarenta y cincuenta. Los tres sintagmas tienen carácter afectivo, y los tres muestran el inicio del procedimiento compositivo (compárese vas o vienes con vaivén), si bien su propio carácter efímero impidió que se llegara a una unión más completa.

Del mismo modo, para que un sufijo sea vivo es preciso que presente una idea neta al espíritu. Cualquier hispanohablante siente una relación entre campo y campiña, pero -iña no es un sufijo porque no cumple tal condición. Y además tiene que conservar capacidad para formar nuevos derivados: es lo que ocurre con -dad, -ero, -ista, -miento.

Y frente a lo actualmente fecundo, lo que va teniendo cada vez menos capacidad para formar derivados nuevos.

Habría que distinguir:

a) Sufijos perdidos o que ya no se sienten como tales: p. ej., el -ulus latino, de diminutivo, que en muchos casos fue sustituido por -ellu $>$-illo. Así canilla no viene de cannula, sino de un vulgar e hipotético cannella, ni rodilla de rotula, sino de rotella. Y las formas cánula y rótula, son de carácter técnico y el hablante no siente en ellas ningún sufijo.

b) Sufijos que se sienten como tales, pero han perdido o van perdiendo vitalidad. Así, el -iego de amplia vitalidad medieval y clásica (andariego, mujeriego, palaciego, solariego, veraniego). Continúa sintiéndose como tal sufijo, pero tiene escasa o nula fecundidad.

O la $-s$ final de las locuciones a ciegas, a horcajadas, a hurtadillas, a mujeriegas, a oscuras, a tontas y a locas. Jacinto Benavente comenzó un parlamento ante un público femenino: «Hablaré a tontas y a locas». Y claro que las señoras no pudieron molestarse, no al menos de manera "oficial». Esta $-s$, aunque originariamente fuera signo de plural, terminó funcionan- 
do como auténtico sufijo adverbial. Muy vivo en otro tiempo, y con poca o ninguna vitalidad actual.

c) Los sufijos actualmente fecundos. Y, por supuesto, lo que comienza a abrirse paso. Todos sabemos que se dice con frecuencia tricotar en lugar de los anteriores hacer punto y hacer media. Tricotar es, simplemente, un préstamo (del francés tricoter). Tiene más interés el término tricotosa, que en $D R A E 1992$ designa tanto a la 'máquina para hacer tejido de punto' como a la 'operaria que trabaja con esta máquina'. Tricotosa es también un préstamo del francés (tricoteuse), pero tiene más interés porque en español, que yo sepa, no se utiliza -osa para formar nombres de máquina o instrumento. En el caso de que se formasen más términos con tal sentido, -osa habría adquirido un nuevo valor.

Frente a la opinión de Bally, que considera que en francés la sufijación está en declive, Pichon considera que no, que no es deficiente más que en la medida en que el prejuicio antineológico mutila la lengua. $Y$ atribuye el aserto de Bally a su mayor respeto por lo libresco y académico, en definitiva, a su «helvetismo».

En español, la sufijación es procedimiento absolutamente vivo, con plena vida y fuerza expansiva, así que (lo mismo que en italiano o en portugués) una discusión semejante no tendría sentido.

La sufijación presenta irregularidades en español y, en general, en las lenguas naturales. Por lo demás, tal carácter — la irregularidad - se extiende al vocabulario en su conjunto. Una de sus causas es la invasión de cultismos, ya que provoca la convivencia de palabras cultas y populares - a veces de formas muy alejadas entre sí- en la misma familia de palabras, con o sin diferenciación semántica.

Así, sobre abrir, abertura y apertura (y abridura, en varios diccionarios del siglo pasado y en América);

sobre quemar, cremación, y quemadura;

junto a caballo, cabalgar y equitación;

sobre agua, acuoso y aguanoso;

sobre ojo, ocular y ojoso.

(se entiende, claro está, que no se establece relación genética entre las formas). 
La irregularidad tiene muy diversas manifestaciones, entre ellas la existente en la expresión de conceptos contrarios. Frente a aptitud, ineptitud pero también inepcia.

De la introducción de cultismos resulta un rejuvenecimiento del idioma.

La irregularidad tiene en la sufijación dos manifestaciones fundamentales:

a) Diversidad de valores en un mismo sufijo. Así, el frecuentísimo -ero puede indicar persona (librero, zapatero), lugar (gallinero, granero), objeto (cenicero, paragüero), árbol (melocotonero) y puede ser adjetivo, en variada relación semántica (según los casos) con su base (callejero, dominguero, cartagenero).

Ejemplos de polivalencia de sufijos pueden encontrarse en todas las lenguas naturales (no en las artificiales, claro está), sobre todo en los sufijos que han tenido una vida larga en la lengua.

b) Diversos sufijos para expresar una misma idea o valor. Para el español son un buen ejemplo las formaciones con valor genérico 'color próximo a': azulado, azulenco, blanquecino, blancuzco, negruzco, amarillento, grisáceo, rojizo, verdoso. En francés y en alemán en este caso habría uniformidad (-átre y -lich, respectivamente), pero se encontrarían fácilmente ejemplos de diversos sufijos para expresar un mismo valor.

Las diferentes clases de sufijos apreciativos ofrecen asimismo variedad de formantes. Claro que en español es -ito el sufijo por excelencia para formar diminutivos sobre nombres, pero hay también otros (-illo, ico, -uelo, -ete, -in, etc.), aunque claro que no son intercambiables. Aun prescindiendo de diferencias regionales y aceptando que -ito es el más frecuente y general, se da una variadísima casuística, en función sobre todo de la base léxica a que se ańade el sufijo y del «color» estilístico del texto, pero también de otros factores.

También hay variedad de sufijos en la derivación apreciativa sobre adjetivos (debilucho, feúcho, paliducho, beatón, santurrón). Y asimismo en la derivación más resueltamente peyorativa (-acho, -ucho, -astro, -ejo, etc.).

También para formar verbos de los llamados «diminutivos» por varios estudiosos: dormitar, carretear, lavotear, canturrear, lloriquear, besuquear. 
Y no digamos de la sufijación general, ya no apreciativa. Piensen ustedes - y no me extenderé en ello- en la variedad de sufijos de acción y efecto (-aje, -ción, -miento, etc.), de cualidad (-dad, -eza, etc.), gentilicios (-ano, -ino, -és, etc.).

Y claro que hay en algunos casos condicionamiento recíproco de los sufijos y de las bases léxicas a que se ańaden, aunque sean los menos. Pena Seijas (1976) señala con razón, por ejemplo, que los verbos en -ecer forman nombres en -miento (abastecimiento, acontecimiento), los en -izar, nombres en -ción (civilización, urbanización), los en -ificar, igualmente nombres en -ción (bonificación, clasificación).

Obsérvese que -iguar es el resultado español del sufijo latino -ificare, que da lugar en español al culto -ificar. Pues bien, los verbos en -iguar, que no son de carácter culto como los en -ificar y son, en general, más antiguos en la lengua, parecen tener tendencia a formar derivados en -miento o en otros sufijos, pero no en -ción (apaciguamiento, santiguada, santiguadera, santiguamiento, santigua - los cuatro últimos vocablos con sentido de acción). Es también cierto que, en los verbos en -ear el derivado habitual (único la mayoría de las veces) es el postverbal en -eo (balanceo, toreo). Pero ocurre asimismo que, en varios verbos, junto al derivado en -eo los hay también con otros sufijos (torpedeamiento/torpedeo, acarreamientolacarreo, cabezamiento/cabeceo, pateamiento/pateadura /pateo). Y en algunos casos, pocos, falta incluso la formación en -eo (boquear/boqueada, broncear/bronceado, cocear/coceamiento/coceadura, pelear/pelea, hermosear /hermoseamiento). Pero la tendencia mayoritaria de los verbos en -ear es la que queda dicha, es decir, formar derivados en -eo.

Estas irregularidades son resultado precisamente de una vitalidad. Pero también el resultado de las vacilaciones, de las alternancias y rivalidades entre sufijos diferentes, de las luchas entre ellos (y eran, desde luego, mucho mayores en la lengua medieval). Y en definitiva tal falta de regularidad sirve a la expresividad, ya que introduce variedad en el discurso.

Termino ya. Piensen ustedes en que la comprobación de qué sufijos se emplean en cada caso lleva aneja la comprobación de cuáles no se emplean. Es decir que, en cada caso, uno o varios (con o sin diferenciación semántica) derivados son posibles y otros no. El muy útil concepto generativista de «bloqueo» incide en este punto. 
A todos estos problemas debe aplicarse nuestro interés para que el estudio sea sobre la lengua española. Evidentemente puede haber distintas razones para seleccionar uno u otro formante. Desde morfológicas hasta semánticas (el carácter del predicado de base), pasando por la posible constitución de «familias" (verbos más o menos sinónimos o antónimos, con tendencia a la igualación o a la diferenciación). Y también, si no nos reducimos a la descripción, razones históricas.

Si prescindimos de estas últimas, y aun sin prescindir de ellas, ya que hemos planteado nuestro estudio como sincrónico, se aprecia sin más la dificultad de dar reglas aplicables a todos los casos. Hasta ahora, que yo sepa, no se ha conseguido en ninguna lengua natural, y desde luego no para el español, este ideal de exhaustividad. Personalmente, no creo que sea alcanzable.

\section{Referencias}

Alemany Bolufer, J. (1920): Tratado de la formación de palabras en la lengua castellana.

Alonso A. (1954): «Noción, emoción, acción y fantasía en los diminutivos», en Estudios lingüísticos. Temas españoles, Madrid, Gredos.

Bally, Сн. (1950): Linguistique générale et linguistique française, Berna, Francke Verlag. Beinhauer, W. (1973): El humorismo en el español hablado, Madrid, Gredos.

Bosque, I. y M. Pérez Fernández (1987): Diccionario inverso de la lengua española, Madrid, Gredos.

Corominas, J. (1954-1957): Diccionario crítico etimológico de la lengua castellana, 4 vols., Madrid, Gredos.

- y J. A. Pascual (1991): Diccionario crítico etimológico castellano e hispánico, 6 vols., Madrid, Gredos.

Cuervo, R. J. (1954): «Apuntaciones críticas sobre el lenguaje bogotano», en Obras, Instituto Caro y Cuervo, Bogotá, 1954, I: 1-906.

Fernández Ramírez, S. (1986): La derivación nominal, ordenado y dispuesto para la imprenta por Ignacio Bosque, Madrid, Anejos del BRAE, XL.

Gili GaYA, S. (1960): Tesoro lexicográfico, Madrid, CSIC.

Hanssen, F. (1913): Gramática histórica de la lengua castellana.

Lang, M. F. (1990), Spanish Word Formation. Productive derivational morphology in the modern lexis, Londres, Nueva York, Routledge, 1990 (hay traducción española en Madrid, Cátedra, 1992).

Meyer-Lüвкe, W. (1921): Historische Grammatik der Banzösischen Sprache, II, Heidelberg. 
Navarro Tomás, T. (1943): Cuestionario lingüístico hispanoamericano, Buenos Aires.

Pena Seijas, J. (1976): Usos anómalos de los sustantivos verbales en español actual, Universidad de Santiago de Compostela.

- (1980): La derivación en español. Verbos derivados y sustantivos verbales, Universidad de Santiago de Compostela.

Pichon, E. (1942): Les principes de la suffixation en français, París.

RaIner, F. (1993): Spanische Wortbildungslehre, Tubinga, Max Niemeyer Verlag.

Real Academia Española (1992): Diccionario de la lengua española, Madrid.

Thiele, J. (1992): Wortbildung der spanischen Gegenwartssprache, Langenscheidt Verlag Enzyklopedie, Leipzig, Berlín, Múnich.

Varela Ortega, S. (1990): Fundamentos de morfología, Madrid, Síntesis.

- (ed.) (1993): La formación de palabras, Madrid, Taurus.

Vera Luján, A. (1986): Aspectos sintáctico-semánticos de la sufijación, Universidad de Murcia.

WaGner, M. L. (1943-1944), «Iberoromanische Suffixstudiem», ZRPh, LXIII y LXIV. 



\title{
EL ELEMENTO CERO \\ COMO RECURSO MORFOLÓGICO \\ EN EL MODELO ITEM AND ARRANGEMENT
}

\author{
Jesús Pena \\ (Universidad de Santiago de Compostela)
}

El elemento cero, inventado ya por Panini en su gramática del sánscrito, se sigue utilizando en la morfología actual para analizar aquellas palabras en las que uno de sus significados parciales no está representado por ningún elemento formal manifiesto. ${ }^{1}$ El recurso conocido como elemento cero o nulo — sean morfos, variantes o realizaciones - aparece en representaciones de estructuras lingüísticas diseñadas en distintos marcos teóricos, pero concretamente en el análisis morfológico fue ampliamente desarrollado en el modelo de análisis conocido como Item and Arrangement (en adelante IA), elaborado por la lingüística distribucional norteamericana de los ańos cuarenta y cincuenta del siglo xx (Pena 1990).

El objetivo de esta contribución consiste en estudiar el desarrollo y aplicación de la noción de morfo cero en el modelo IA. El texto está estructurado como sigue: en el apartado 1 se exponen algunas de las características principales del modelo que desencadenan la utilización de elementos cero; en el apartado 2 se describe el recurso del morfo cero como procedi-

1 Haspelmath (2002: 33): «Another phenomenon that causes problems for segmentation is the existence of words in which a morfological meaning corresponds to no overt formal element; this is generally called zero expression». 
miento analítico en la versión inicial del modelo IA; en el apartado 3 se examinan las sucesivas restricciones a que es sometido el empleo del morfo cero ante las dificultades que plantea su aplicación indiscriminada en el análisis. Finalmente, en el apartado 4 se extraen algunas conclusiones.

\section{Principios fundamentales del modelo IA}

Los postulados del modelo IA figuran ya en Bloomfield (1926, 1935). Su desarrollo, en lo que a procedimientos analíticos se refiere, será obra de la lingüística postbloomfieldiana, representada por Harris, Hockett, Bloch, Wells, Nida, etc. ${ }^{2}$ En este modelo se supone que todo enunciado (utterance) está integrado en sus constituyentes últimos por morfemas en una determinada distribución mutua: ${ }^{3}$

One assumes that any utterance in a given language consists wholly of a certain number of minimum grammatically relevant elements, called morphemes, in a certain arrangement relative to each other. The structure of the utterance is specified by stating the morphemes and the arrangement (Hockett 1954: 212).

El análisis lingüístico consistirá, por tanto, en tomar un determinado enunciado e ir descomponiéndolo en sus constituyentes inmediatos sucesivos hasta llegar a delimitar las unidades significativas mínimas. El resultado final del análisis será una lista de morfemas concatenados en un determinado orden, que proporcionará la estructura lingüística del enunciado entendida como estructura distribucional de los morfemas que lo integran: "The linguistic structure of an utterance is presumed to be fully stated by

2 Como dice Hockett (1947: 213), «there are few full grammatical descriptions which illustrate IA in its purest form». Y es que, tanto en Bloomfield como en sus seguidores, la descripción de este modelo conlleva aparejadas nociones y técnicas del modelo IP (Item and Process). De entre los trabajos originales que describen el modelo IA de un modo más homogéneo, cabe destacar Harris (1942), Bloch (1947), Hockett (1947); de especial interés son Lounsbury (1953) y Hockett (1954), en los que se contrastan los modelos IA e IP.

3 En el modelo IA desaparece la distinción tradicional entre morfología y sintaxis pues, sea cual sea el grado de complejidad de la unidad gramatical, el procedimiento formal de análisis es siempre el mismo: «Any sentence, phrase, or complex word can be described as consisting of such-and-such morphemes in such-and-such an order; each morpheme has a meaning, and so also has the order in which they occur (the 'constructional meaning')» (Bloch 1947: 399-400). 
a list of the morphemes which constitute it, and by their order» (Harris 1948: 87). En este sentido, la igualdad o diferencia entre dos enunciados dependerá de la igualdad o diferencia de su "morphemic constituency» (Harris 1948: 87) o, dicho con otras palabras, de «their linguistic elements and the distributional relations among these elements» (Harris 1951: 16).

Las unidades gramaticales mínimas obtenidas en el análisis se denominan morfemas; las representaciones fonémicas de las palabras, los segmentos recurrentes, se denominan morfos. Las relaciones que en el interior de la palabra guardan entre sí tanto los morfemas como los morfos que los representan son de tipo secuencial o lineal.

La relación morfo-morfema es una relación de alomorfia o alternancia. Considerado el morfema como grupo de alomorfos, la relación de alomorfia se interpreta como la relación que existe entre un morfo y el morfema, concebido inicialmente como clase o grupo de alomorfos. Ahora bien, dentro del propio modelo, de la definición del morfema como 'clase o grupo de alomorfos' se pasa a la de morfema como 'entidad gramatical abstracta correspondiente al segmento fonémico recurrente mínimo'. De este modo, la relación de alomorfia pasa a concebirse como la relación que, en el interior de la palabra, hay entre los segmentos separados de la 'phonological word', los morfos, y los segmentos separados de la 'grammatical word', los morfemas. ${ }^{4}$ Gráficamente, el análisis de una palabra como writers puede representarse como sigue: ${ }^{5}$

4 La relación morfema-morfo suele plasmarse por medio de la expresión «el morfema está representado por un morfo o alomorfo", que es la misma que se emplea para expresar la relación fonema-fono (véase, por ejemplo, Hockett 1958). El propio Hockett (1961) presenta y discute una concepción diferente. Según él, hay dos métodos para pasar del morfema al fonema: el mórfico y el morfofonémico. En el primer caso se supone que los morfemas están representados por morfos y estos constituidos por fonemas; en el segundo caso se supone que los morfemas están constituidos por morfofonemas y estos representados por fonemas. Los elementos relacionados por constitución «are by definition elements of the same stratum of a language, but of different size-levels" (Hockett 1961: 41); los elementos relacionados por representación «are by definition elements of roughly the same size-level, though of different strata» (ibíd.). La relación morfema-fonema no puede ser una relación simple de composición ya que ambas unidades pertenecen a dos «strata of linguistic patterning, grammatical and phonological». El morfema no se compone de fonemas: se proyecta en (is mapped into) fonemas.

5 Sigo a Matthews $(1970,1974)$ en las convenciones gráficas utilizadas: vERSALITAS para los morfemas y cursiva para los morfos. 


\begin{tabular}{|l|c|c|c|}
\hline representación morfémica & WRITE & AGENTIVO & PLURAL \\
(palabra gramatical) & $\uparrow$ & $\uparrow$ & $\downarrow$ \\
& $\downarrow$ & $-e r-$ & $-s$ \\
representación mórfica & writ- & /er/ & /z/ \\
(palabra fonológica) & /rait/ & \\
\hline
\end{tabular}

Esquema en el que morfos y morfemas están ordenados secuencialmente y emparejados en una correspondencia uno a uno. Las relaciones sintagmáticas entre las unidades, tanto entre los morfemas como entre los morfos, son siempre de tipo secuencial. Así, en el ejemplo representado, el morfema WRITE precede al morfema AGENTIVO y este al morfema PLURAL; del mismo modo, el morfo writ- precede al morfo -er- y este al morfo -s. La relación alomórfica hace referencia al emparejamiento de morfos y morfemas «in an exhaustive one-to-one correspondence, according to the order in which they appear at their respective levels» (Matthews 1972: 4950); así, el segmento writ- es el alomorfo de WRITE, -er- el alomorfo de AGENTIVO y $-s$ el alomorfo de PLURAL.

La esencia del modelo radica precisamente en el concepto de relación alomórfica, que hace referencia al simple emparejamiento de morfos y morfemas en una exhaustiva correspondencia uno a uno entre morfo y morfema según el orden en que aparecen en sus respectivos niveles (gramatical y fonológico): en el análisis de la palabra, cada morfema debe estar representado por un segmento o morfo manifiesto y distinto de otro u otros.

\section{La noción de morfo cero en la versión inicial del modelo IA}

Uno de los recursos más empleados en el análisis, sobre todo en la versión inicial del modelo, es el del elemento cero para dar cuenta de aquellos casos en que, al segmentar la forma fonémica de una palabra en morfos y asignarlos como alomorfos a morfemas, aparece una posición donde no hay segmento fonémico que se pueda adscribir como alomorfo del morfema correspondiente en la representación gramatical, que sí hay en otras formas gramaticalmente paralelas u opuestas directamente. Así, en desk-s, gramaticalmente DESK + PLURAL, cada elemento gramatical o morfema tiene su representante mórfico o exponente; pero en desk, gramaticalmente DESK + 
SINGULAR, la segunda posición correspondiente al morfema SINGULAR no está ocupada por ningún segmento; está vacía. La ausencia, en esta posición, de un segmento que se pueda asignar como alomorfo del morfema SINGULAR se interpreta como elemento cero, denominado morfo cero o alomorfo cero, y suele simbolizarse por /Ø/. De este modo, el análisis mórfico de desk será /desk- Ø/; desk y desks son dos formas que gramaticalmente se oponen directamente y esa oposición se manifiesta mediante la presencia frente a la ausencia del morfo -s: /desk-s/ PLURAL frente a /desk- Ø/ singular. Ejemplificando con el español, en la forma flexiva amigos cada uno de sus tres significados parciales (AMIGO, MASCULINO y PLURAL) está representado por su morfo correspondiente (amig-, - o- y -s), pero en amigo la posición correspondiente a SINGULAR no está ocupada por ningún segmento: amig-o- $\varnothing$. Resulta evidente que el morfo cero es un elemento ficticio; se trata de un recurso en el análisis que, como se puede observar, sirve para preservar el requisito de la correspondencia uno a uno entre morfo y morfema.

También se utiliza el morfo cero en el análisis de las formas homónimas dentro de la flexión; en desk-s, PLural de desk, figura el morfo -s que representa PLURAL; pero en sheep, donde la misma forma fonémica puede representar tanto SINGULAR Como PLURAL, el morfema PLURAL no está representado por nada. Para seguir manteniendo en el análisis el paralelismo entre la representación gramatical o morfémica y la mórfica, se recurre al morfo cero $\left(\right.$ SHEeP + PLURAL $=/ \int \mathrm{i}: \mathrm{p}-\varnothing /$ ) y del morfo $/ \varnothing /$ se dice que es un alomorfo más, en este caso morfémicamente condicionado, de PLURAL junto con los alomorfos /-s/, /-z/ e /-iz/. En las palabras del español casa-s y cordel-es aparecen los alomorfos $-s$ y -es que representan PLURAL, pero en crisis, lunes o caries, donde la misma forma puede representar tanto el SINGULAR como el PLURAL, el morfema de PLURAL no está representado por nada. Para seguir manteniendo en el análisis el paralelismo entre el significante y el significado, se recurre al morfo cero: crisis- $\varnothing$, lunes- $\varnothing$, caries- $\varnothing$, y del morfo cero se dice que es un alomorfo más de PLURAL (en este caso fonológicamente condicionado: figura en palabras de dos o más sílabas no oxítonas acabadas en -s), junto con los alomorfos -s y -es: crisis- $\varnothing$, casa-s, mantel-es.

Otro ejemplo de homonimia en la flexión, en este caso flexión verbal, donde se recurre al morfo cero es el siguiente: en wait-ed, PASADO (o PARTICIPIO) de wait, aparece el morfo -ed/-id/ que representa el morfema PASADO (o PARTICIPIO); pero en bet, hit, let, set, etc., donde la misma forma 
fonémica es exponente de PRESENTE y PASADO (o PARTICIPIO), la posición correspondiente a PASADO (y PARTICIPIO) está vacía. Para seguir manteniendo el paralelismo entre la representación morfémica y la representación mórfica, se utilizará también el morfo cero (/bet- $\varnothing /$, /hit- $\varnothing /$, /let- $\varnothing /$, /set- $\varnothing /$ ) y se hablará del alomorfo /Ø/ de PASADo (y PARTICIPIO), también morfémicamente condicionado, al lado de los alomorfos fonémicamente condicionados /-d/, /-id/ y /-t/.

La flexión del verbo en español, más compleja que la del inglés, ofrece un terreno abonado para el recurso del elemento cero. En este caso ya se admite que el significante de una forma flexiva no siempre es descomponible en tantos morfos parciales cuantos contenidos parciales integran su significado global. En cant-á-se-mos, por ejemplo, -se-soporta los contenidos categoriales de modo y tiempo, y -mos los de número y PERSONA. Aún así, si contrastamos las formas flexivas cantásemos, cantamos, cantase y canta, vemos que cualquiera de los constituyentes flexivos puede faltar en una determinada forma verbal: ausencia del sufijo de MODO-TIEMPo (cant-a- $\varnothing$-mos), del sufijo de NúmERo- PERSONA (cant-a-se- $\varnothing$ ) y ausencia de ambos sufijos flexivos (canta-Ø-Ø). Esta última forma la encontramos en dos lugares distintos del paradigma (tercera persona singular del presente de indicativo y segunda persona singular de imperativo), de donde resulta que en canta- $\varnothing-\varnothing$ hay dos morfos cero homónimos. Este procedimiento analítico sigue hoy vigente en la Gramática de la $R A E$ (2009: 188-203), donde se sigue fielmente a Alcoba (1999). He aquí algunos ejemplos representativos de este modo de operar: amo /ám- $\varnothing-$-o- $\varnothing /$ - lám- $\varnothing-\varnothing-\mathrm{o} /$ ), ama (indicativo e imperativo presente) / ám-a-Ø-Ø/, ame lám-Ø-e-Ø/, amé /am-Ø-é-Ø/, etc.

Finalmente, también se recurre al morfo cero en el análisis de formas como men, PLURAL de man, y took, PASADO de take. La forma man representa MAN + SINGULAR y men MAN + PLURAL, y la oposición gramatical presente en ambas formas es la misma que se plasma en book books, desk desks, dog dogs, etc. ¿Dónde está representado el morfema PLuRAL en men? Hay una diferencia de timbre vocálico entre man y men pero, como no hay afijo en la posición correspondiente a PLURAL que sí hay en books, desks y dogs, esa diferencia de timbre se interpreta como un hecho de alomorfía y se considera que el PLuRAL está representado por el morfo cero. La forma men consta del morfo /men-/, alternante morfémicamente condicionado de MAN, y del alomorfo cero morfémicamente condicionado de PLURAL: /men- $\varnothing /$. 
Cabe interpretar del mismo modo una forma verbal como took: la oposición gramatical que expresan las formas take y took es proporcional a la de look looked, wait waited, etc. La diferencia de timbre se interpreta igualmente como alternancia entre los alomorfos del morfema TAKE (/teik/ y /tuk/) y el morfema de PASADO está representado por un morfo cero; la forma took, pues, consta del morfo /tuk-/, alternante morfémicamente condicionado de TAKE, y del alomorfo cero morfémicamente condicionado de PASADO.

\section{Sucesivas restricciones al empleo del morfo cero}

A la vista de los ejemplos expuestos, resulta evidente que el recurso del morfo cero se aplica a casos cuyo denominador común es la carencia, en determinadas posiciones, de algún morfo asignable como alomorfo de un morfema; tales casos presentan, sin embargo, notables divergencias hasta el extremo de que, de interpretar conjuntamente como morfos cero las tres aplicaciones detalladas en el apartado 2, se incurre en incongruencias evidentes. Así, si para la flexión nominal se habla de un morfo cero de sINGULAR, tendremos tanto en desk como en sheep un morfo cero; si, por otro lado, para sheep PLURAL se habla también de un alomorfo cero, resulta que en sheep tanto SINGULAR como PLURAL están representados por /Ø/; si, por el contrario, se utiliza el morfo cero para el PLURAL de sheep y no para el SINGULAR, resulta que la oposición SINGULAR/PLURAL se plasma en la diferencia existente entre la ausencia y la presencia del morfo cero, lo cual no deja de ser un contrasentido (véase Matthews 1974: 117). El uso del morfo cero, útil en principio en cuanto que sirve para plasmar el paralelismo gramatical entre formas mórficamente diferentes, puede convertirse en un recurso complejo y débil si se usa de un modo tan libre o heterogéneo, pues no hay límite que lo acote. De ahí que se haya intentado establecer ciertas reglas para restringir su empleo.

Una de las reglas indica que no debe usarse el morfo cero cuando este resulte ser el único alomorfo del morfema; dicho con otras palabras, un morfema no puede aparecer representado siempre como cero. ${ }^{6}$ Por consi-

6 Esta restricción, que ya aparece en Bloch (1947), será mantenida en general en el análisis morfémico. En Bloomfield (1926) y Harris (1942) se habla de un morfo cero para desk pero no en Bloomfield (1935) ni en Harris (1951). 
guiente, debe descartarse el uso de cero para el primer caso ejemplificado: en desk no hay un morfo cero de singular pues sería el único alomorfo de dicho morfema; la forma desk debe considerarse monomórfica.

Otra de las reglas recomienda no emplear el morfo cero en aquella forma flexiva que no se oponga a otra con la presencia de un morfo en la posición correspondiente; dicho de otro modo, no debe recurrirse al morfo cero para expresar los dos miembros de una oposición gramatical (Haas 1957, Saporta 1959, 1964). Debe eliminarse, pues, el morfo cero en el análisis de las formas homónimas dentro de la flexión, tipo sheep SINGULAR y PLURAL o bet PRESENTE, PASADO y PARTICIPIO, ya que este morfo cero se opondría a su ausencia y la regla precisamente impide que el cero se oponga a la ausencia de cero.

Por último, otra de las restricciones formuladas para el uso de cero afecta al tercer caso, el ejemplificado con men PLural y took pasado. Dice así: no debe proponerse en una forma fonémica un morfo cero si ello conlleva considerar el segmento restante (o uno de ellos) como alomorfo particular de otro morfema; dicho de otro modo, no debe emplearse un morfo cero cuando en la forma fonémica hay alguna diferencia patente a la que asignar el morfema (Nida 1948, Lounsbury 1953). Proponer un morfo cero en men (/men- $\varnothing /)$ implica considerar el segmento restante $(/ \mathrm{men}-/)$ como alomorfo particular, junto con /man-/, del morfema MAN; de igual modo, defender un morfo cero en took (/tuk- $\varnothing /$ ) supone postular un alomorfo particular/tuk-/ de TAKE, que alterna con /teik-/; pero, tanto en men con respecto a man, como en took con respecto a take, hay una diferencia fonémica patente, el timbre vocálico, e intentar asignar la oposición SINGULAR/ PLURAL O PRESENTE/PASADO a un morfo cero cuando hay una diferencia fonémica manifiesta supone despreciar una diferencia fonémica patente y crear a cambio una que se supone latente (Nida 1948).

Si se aplican las tres restricciones descritas, resulta que desaparece del análisis el morfo cero como recurso analítico en los tres casos ejemplificados. Hay que decir a este respecto que no hay uniformidad en la aplicación del morfo cero y, por tanto, tampoco en las restricciones de uso; de ahí que hayamos expuesto el recurso del morfo cero en sus dos vertientes extremas: posibilidades de empleo y restricciones potenciales en su utilización. Queda por examinar cuáles son las posibilidades de análisis si se evita el recurso del morfo cero en los tres casos mencionados, de acuerdo con las tres res- 
tricciones formuladas. En los dos primeros casos —el de desk SINGULAR y el de bet, hit, let, set, etc., PASADO y PARTICIPIO- el problema se resuelve tratando dichas formas como formas monomórficas, de donde se infiere que ya no se mantiene el requisito inicial del modelo consistente en mantener la correspondencia uno a uno entre morfo y morfema.

El análisis que presenta una solución más compleja atañe a unidades como men y took; la diferencia fonémica con man y take, respectivamente, resulta evidente y, por ello, no parece tener sentido recurrir al morfo cero; pero, ¿cómo se debe interpretar esa diferencia de timbre vocálico? Han sido varias las soluciones apuntadas y ninguna de ellas parece totalmente adecuada dentro del modelo IA. ${ }^{7}$ Ejemplificando solamente con took, se podría interpretar también took como forma monomórfica; pero esta alternativa parece de difícil aceptación porque o es alternante de take, en cuyo caso tiene el mismo significado, o no es un alternante de take, en cuyo caso tiene un significado distinto. Resulta evidente que ninguna de las dos opciones es adecuada: take y took no tienen ni el mismo significado ni significados distintos, sino un significado en parte común y en parte diferente (Bloch 1947).

Habrá que considerar entonces took como forma bimórfica. También aquí caben varias interpretaciones. En primer lugar, cabe considerar en took/tuk/ un morfo discontinuo/t-k/ como alomorfo de TAKE y un infijo /-u-/ como alomorfo de PASADo, solución que no suele tenerse muy en cuenta por considerar que la infijación no es un procedimiento regular en inglés y porque tal solución obligaría a segmentar también la forma take en /t-k/ y /ei/, lo que nunca se hace (véase Hockett 1954). En segundo lugar, se puede interpretar took como un 'portmanteau morph': dos morfemas representados normalmente por dos morfos separables (cf. sail-ed, work-ed, wait-ed, etc.) aparecen aquí representados por un solo morfo; esta solución adolece del mismo defecto que la del morfo cero pues ambas descartan la diferencia fonémica existente entre take y took. ${ }^{8}$ Por último, hay que mencionar la solución que ha sido más utilizada dentro del modelo: en took hay dos morfos, uno take, alomorfo de TAKE, y otro /ei/ $\rightarrow$ /u/, morfo

7 Las posibles soluciones están recogidas en Bloch (1947) y más tarde en Hockett (1954).

8 Esta es la solución aportada por Hockett (1947: 339-340; 1954: 223-224); pero el propio autor la descarta por la razón indicada. 
de PASADO, que debe leerse «/ei/ es sustituido por /u/»; este morfo se denomina 'morfo sustitutivo' ('replacive morph'); 9 ' pero, paradójicamente, esta interpretación resulta inadmisible si se quiere mantener un mínimo de coherencia dentro del modelo: hablar de sustitución de unos fonemas por otros no es hablar de morfos y alomorfos o alternantes sino de procesos mediante los cuales una forma se convierte en otra y en eso consiste precisamente la técnica de análisis propia del modelo IP. ${ }^{10}$ En definitiva, casos como los de man men y take took resultan de difícil análisis para el modelo IA. Quizá la solución más coherente dentro del modelo sea la consistente en un morfo discontinuo y un infijo (véase Hockett 1954: 224).

\section{A modo de conclusión}

Las dificultades con las que tropieza el modelo IA son evidentes y provienen del intento, fallido por otra parte, de mantener los principios básicos del análisis morfémico según la versión inicial. El propósito de preservar en el análisis el principio de la relación alomórfica —entendida como el emparejamiento morfo-morfema en la correspondencia uno a uno- supone un coste notable para el método, pues hay bastantes fenó-

9 Esta interpretación la utiliza ya Bloomfield, quien, a propósito de los plurales tipo men, dice: «In these plurals a grammatical feature, phonetic modification, expresses a meaning (namely, the sememe 'more than one object') which is normally expressed by a linguistic form (namely, the morpheme $[-\mathrm{ez},-\mathrm{z},-\mathrm{s}]$ ). We may say that «substitution of [ij]» in geese, teeth, feet, "substitution of [aj]» in mice, lice [...] are alternants of the normal pluralsuffix: substitution-alternants or substitution-forms» (Bloomfield 1935: 216). A igual explicación acude Harris: «In took we have two morphemes: take, and /ej/ /u/ 'past time'. The latter occurs also in shook as compared with shake. It is a combination of negative and additive sequences: dropping /ej/ and adding/u/. Another negative-additive morpheme is /a/ /e/ 'plural', which occurs in men as compared with man» (Harris 1942: 171).

10 El mismo comentario merece el denominado 'morfema sustractivo' (substractive morph o minus-morph), que consiste en restar en una forma un segmento para obtener otra forma distinta. El procedimiento ya aparece en Bloomfield (1935: 217) para describir la flexión del adjetivo en francés: se toma como base la forma femenina y de ella se obtiene la forma masculina mediante elisión de la consonante final: platte/plat/ $\rightarrow$ plat/pla/; el morfo sustractivo es /t/ $\rightarrow / \varnothing /$, que se lee así: /t/ es sustituido por cero.

Bloch es uno de los pocos estudiosos que no admite esta técnica de análisis: «if a morpheme is ultimately a combination of phonemes, then it is clear that vowel change, a process, is not a morpheme» (Bloch 1947: 400). Para este autor, en el análisis morfémico se debe evitar «all reference to the process by which the form is derived» (Bloch 1947: 401). 
menos que contradicen dicho principio: el recurrir dentro del modelo a nociones como morfo cero, morfo vacío, morfo redundante, morfo acumulativo, etc., muestra con claridad hasta qué punto resulta inadecuado el principio de la relación alomórfica. De los recursos utilizados, solo el morfo cero y el morfo vacío intentan preservar el principio de un morfo por morfema pero, como acabamos de mostrar, a costa de un uso complejo y heterogéneo del elemento cero, que acaba por convertir el análisis en algo bastante artificial. Los demás recursos suponen contravenir el modelo IA en sus aspectos esenciales (véase Pena 1990): la no correspondencia uno a uno entre morfo y morfema (morfo superpuesto, acumulativo y redundante), el carácter no discreto de los morfos (morfo superpuesto), el carácter no discreto de los morfemas y, por consiguiente, la no determinabilidad de sus relaciones secuenciales (morfo acumulativo) o la definición del morfo, no en términos de fonemas y de combinaciones de fonemas, sino en términos de procesos que cambian una forma fonémica en otra (morfo sustitutivo y morfo sustractivo).

\section{Referencias}

Alcoba, S. (1999): «La flexión verbal», en I. Bosque y V. Demonte (dirs.), Gramática descriptiva de la lengua española, Real Academia Española, colección Nebrija y Bello, Madrid, Espasa Calpe: 4915-4991.

BLoch, B. (1947): «English verb inflection», Language, 23: 399-418.

Bloomfield, L. (1926): "A set of postulates for the science of language», Language, 2: 153-164.

- (1935): Language, Londres, Allen and Unwin.

HaAs, W. (1957): «Zero in linguistic description», Studies in Linguistic Analysis, Oxford, Blackwell: 33-53.

HARrIs, Z. S. (1942): «Morpheme alternants in linguistic analysis», Language, 18: 169-180.

- (1948): "Componential analysis of a hebrew paradigm», Language, 24: 87-91.

- (1951): Methods in Structural Linguistics, Chicago, University of Chicago.

Haspelmath, M. (2002): Understanding Morphology, Londres-Nueva York, Oxford University Press.

Hocketт, C. (1947): «Problems of morphemic analysis», Language, 23: 321-343.

- (1954): «Two models of grammatical description», Word, 10: 210-231.

- (1958): A Course in Modern Linguistics, Nueva York, Macmillan.

- (1961): «Linguistic elements and their relations», Language, 37: 29-53. 
Lounsbury, F. G. (1953): Oneida Verb Morphology, en Yale University Publications in Anthropology, 48, New Haven, Yale University Press.

Matthews, P. H. (1970): «Recent developments in morphology», en J. Lyons (ed.), New Horizons in Linguistics, Harmondsworth, Penguin Books: 96-114.

- (1972): Inflectional Morphology: a theoretical study based on aspects of Latin verb conjugation, Cambridge, Cambridge University Press.

- (1974): Morphology: an introduction to the theory of word-structure, Cambridge, Cambridge University Press.

NidA, E. (1948): «The identification of morphemes», Language, 24: 414-441.

PenA, J. (1990): «Sobre los modelos de descripción en morfología», Verba, 17: $5-75$.

Real Academia Española (2009): Nueva gramática de la lengua española, Madrid, Espasa.

Saporta, S. (1959): «Morpheme alternants in Spanish», en H. R. Kahane y A. Pietrangeli (eds.), Structural Studies in Spanish Themes, Salamanca: 19-162.

- (1964): "On the use of zero in morphemics», en H. Lunt (ed.), Proceedings of the Ninth International Congress of linguists, La Haya, Mouton: 228-231. 


\title{
EL SIGNIFICADO PROCEDIMENTAL: RUTAS HACIA UNA IDEA ${ }^{1}$
}

\author{
Manuel Leonetti \\ (Universidad de Alcalá) \\ M. Victoria EsCANDELL-VIDAL \\ (UNED)
}

\section{El significado como conjunto de instrucciones}

El problema de cómo se deben entender las distinciones Gramática / Pragmática y Semántica / Pragmática ha ocupado un lugar destacado en el desarrollo de la teoría pragmática desde las propuestas iniciales de Austin, Searle y Grice. Es lógico que haya sido así, ya que sobre las distinciones citadas se asienta la posibilidad de definir con nitidez el ámbito de la Pragmática como disciplina independiente. Ariel (2010) ofrece un excelente estudio de esta cuestión en el que se defiende de manera convincente la que parece ser la única solución razonable para el problema de la delimitación del campo: la equiparación del ámbito de la Gramática / Semántica con lo codificado, por un lado, y del ámbito de la Pragmática con lo inferido, por otro (tal y como se había propuesto en Sperber y Wilson 1986). La postura expuesta en Ariel (2010) lleva a descartar criterios de delimitación clásicos, pero problemáticos, como la distinción entre contenidos

1 Este trabajo forma parte de la investigación desarrollada en el proyecto financiado FFI2009-07456 (SPYCE II: «Semántica procedimental y contenido explícito II»). 
veritativo-condicionales y no veritativo-condicionales, y permite plantear con claridad nuevas preguntas y debates. Una de estas preguntas es la de si todos los contenidos codificados son del mismo tipo. Es aquí donde la idea de significado procedimental, tema central de este trabajo, adquiere una relevancia especial.

Por significado procedimental (o de procesamiento, o instruccional) se entiende un contenido lingüístico que no corresponde a conceptos ni a imágenes mentales, sino a algo habitualmente no accesible a la introspección: se trata de instrucciones relativas a las operaciones inferenciales que deben realizarse en la interpretación de un enunciado, fundamentalmente para seleccionar los supuestos contextuales necesarios para tal interpretación (Blakemore 1987). El significado procedimental indica cómo procesar y combinar entre sí las representaciones conceptuales. Al imponer condiciones sobre la fase inferencial de la interpretación, las instrucciones de procesamiento requieren una representación proposicional sobre la que operar, pero no son ellas mismas constituyentes de la proposición expresa$\mathrm{da}-\mathrm{y}$ en esto difieren sustancialmente de los contenidos semánticos que denominamos conceptuales - Se ha atribuido un contenido procedimental o instruccional a elementos lingüísticos cuyo significado es, en general, difícil de tratar en términos conceptuales, como los marcadores discursivos, la entonación, o los adverbios focales. El análisis semántico de estos elementos, pues, consistirá en precisar qué instrucción o conjunto de instrucciones codifican, y cómo se combina este contenido con el de otras piezas del sistema gramatical (véanse Portolés 2004: cap. 14, EscandellVidal, Leonetti y Ahern 2011 y Wilson 2011 para un panorama más completo).

La justificación fundamental para tratar de definir qué es el significado procedimental radica en la dificultad de analizar todos los significados lingüísticamente codificados en una lengua como si fueran del tipo conceptual. En estas páginas vamos a dar por supuesto que de hecho esto no es posible, y que ciertos significados solo pueden tratarse como (conjuntos de) instrucciones. Sin embargo, nuestro interés no se concentrará en mostrar por qué necesitamos la noción de significado procedimental, sino en analizar de qué forma se ha presentado esta noción en diferentes modelos lingüísticos en las últimas décadas. Si bien es posible rastrear una conexión clara entre la distinción procedimental / conceptual en Lingüística y la dis- 
tinción computación / representación en el ámbito de la inteligencia artificial y la psicología cognitiva (cf. Thagard 2005), nuestro repaso no incluirá la historia de esa conexión, sino que tomará como punto de partida ciertas propuestas en la lingüística francesa de los años setenta, para compararlas con otros desarrollos más recientes. Las páginas que siguen están dedicadas a revisar la historia (reciente) de la idea de significado procedimental.

\section{Tres caminos}

\subsection{La Teoría de la Argumentación}

La Teoría de la Argumentación desarrollada por Oswald Ducrot y Jean-Claude Anscombre (cf. Anscombre y Ducrot 1983) presenta una formulación explícita de la noción que nos interesa: la significación de una expresión lingüística es un conjunto de instrucciones para asignar un sentido (una interpretación) a su uso en un enunciado. Se llega a esta conclusión a partir de la observación del uso de elementos lingüísticos como casi o apenas, que introducen en el discurso restricciones sobre el tipo de conclusiones hacia las que se orientan los enunciados que los contienen. Dichas restricciones se explican en términos de instrucciones relativas al potencial argumentativo delos enunciados. En otras palabras, la caracterización semántica de las expresiones incluye indicaciones sobre cómo contribuyen a la orientación argumentativa. Mientras que en las primeras versiones de la teoría de Anscombre y Ducrot el componente argumentativo estaba presente en la descripción semántica junto con un componente informativo o descriptivo (veritativo-condicional), en versiones sucesivas lo argumentativo se convierte en primordial y básico, tanto que el valor semántico de las expresiones consiste en la capacidad de suscitar «la adopción de puntos de vista argumentativos» y de condicionar la dinámica discursiva. Este argumentativismo radical lleva a suponer que los significados de las palabras — de todas ellas - no son constituyentes de la proposición expresada por un enunciado, sino instrucciones para legitimar encadenamientos argumentativos (en términos de Anscombre y Ducrot, "haces de topoi», o sea, de principios que garantizan la obtención de conclusiones a partir de argumentos). La conclusión inevitable es que, en algún sentido, todo el significado es argumentativo, así como procedimental —aunque en 3.2 matiza- 
remos esta equiparación-, por lo que los aspectos informativos (es decir, de representación del mundo) del significado quedan desterrados de la Semántica, a favor de la problemática noción de topos.

Las consecuencias para la teoría semántica son graves, como hace notar Iten (1999: 71-73): entre otras cosas, se hace imposible afrontar el problema de la composicionalidad, y distinguir entre conocimiento lingüístico y conocimiento enciclopédico, dado el estatuto híbrido de los topoi (cf. Portolés 2004: 240-241). Además, esta postura entra en contradicción con la premisa de que la Teoría de la Argumentación es una teoría exclusivamente semántica. No es nuestra intención comentar aquí las dificultades a las que ha de enfrentarse la teoría de Anscombre y Ducrot. Nos basta con señalar que en ella el papel fundamental concedido a la argumentatividad conduce a sostener que el significado de las palabras en general -y no solo de algunas de ellas- corresponde a (conjuntos de) instrucciones, entendidas como topoi. Este es, pues, uno de los caminos que podemos seguir para integrar la idea de significado procedimental en la Semántica.

\subsection{Sintaxis Dinámica}

El modelo teórico denominado Sintaxis Dinámica (Dynamic Syntax) ha sido desarrollado en las dos últimas décadas por Ruth Kempson y sus colaboradores (cf. Kempson 2000, y Kempson, Cann y Purver en prensa, para una presentación). Supone un intento explícito y formalizado de dar cuenta de cómo los hablantes construyen la interpretación de los enunciados de forma incremental basándose en información lingüística y en información contextual. La sintaxis se concibe como el proceso por el que se construyen representaciones semánticas a partir de las instrucciones asociadas a las palabras y de la información contextual. Tales instrucciones guían el desarrollo incremental de la representación y pueden acceder a datos contextuales. Lo que distingue al modelo de Kempson de otros enfoques formales es que en él la sintaxis se identifica con el procesamiento de las secuencias y con los procedimientos de actualización progresiva de interpretaciones parciales. No es casual que los datos a los que se ha aplicado con mejores resultados tengan que ver con anáfora, elipsis y estructura informativa, fenómenos caracterizados por una fuerte dependencia del contexto. 
Esta brevísima presentación del modelo es obviamente insuficiente para entender su funcionamiento, pero basta para comprobar que la idea de instrucción o procedimiento desempeńa en él un papel primordial. Según Kempson, muchas palabras contribuyen a la interpretación con la especificación (parcial) de algún concepto, pero TODAS ELLAS codifican procedimientos o instrucciones: "[...] all words provide a set of procedures relative to which a hearer progressively constructs a structure corresponding to the proposition expressed» (Kempson 2000: 423). El sistema gramatical entero es un conjunto de instrucciones para la construcción de proposiciones (cf. también Espinal 1996).

No hay, pues, una distinción teórica entre elementos con significado conceptual y elementos con significado procedimental, ya que los contenidos conceptuales están asociados también a instrucciones para su elaboración en el contexto. Los pronombres y los marcadores discursivos codifican restricciones e instrucciones que determinan solo parcialmente la interpretación, como se suele suponer, y lo hace también el resto de las palabras, incluyendo las que solemos considerar de contenido conceptual, así como las reglas de la sintaxis. El enfoque de Kempson aboga por un uso generalizado de la idea de significado como conjunto de instrucciones, y en este sentido acaba coincidiendo - por lo menos de forma superficialcon la perspectiva defendida en las versiones avanzadas de la Teoría de la Argumentación. Los motivos que subyacen a esta postura, sin embargo, son muy diferentes en los dos modelos.

\subsection{La Teoría de la Relevancia}

Es en la Teoría de la Relevancia, presentada como modelo cognitivo de la comunicación humana en Sperber y Wilson (1986), donde la distinción entre significado conceptual y significado procedimental se ha explorado con mayor interés. La justificación teórica de la existencia de contenidos procedimentales está en el supuesto de que el significado codificado en el sistema lingüístico determina solo parcialmente la interpretación global de los enunciados, es decir, solo proporciona indicios fragmentarios de cuáles son los pensamientos que deseamos comunicar a nuestro interlocutor: ello implica que la interpretación, tanto en el nivel de la explicatura (la proposición explícitamente comunicada) como en el de las implicaturas, se obtiene siempre por vía inferencial y es fuertemente dependiente del con- 
texto, lo que a su vez hace que sea previsible que una parte del significado codificado tenga como función la de orientar, restringir y hacer menos costosa la omnipresente inferencia pragmática.

Los trabajos desarrollados hasta ahora en el seno de la Teoría de la Relevancia suelen concebir la distinción como una separación estable y nítida (es decir, no gradual) entre dos clases de contenidos semánticos, y a veces incluso entre dos grandes grupos de clases de palabras (cuando se acepta la idea de que las categorías funcionales de la sintaxis son procedimentales, cf. Escandell Vidal y Leonetti 2000, Leonetti y Escandell Vidal 2004). Esto ha llevado a muchos investigadores a suponer que, en principio, la distinción debería ser excluyente, de modo que las palabras no pudieran contener al mismo tiempo los dos tipos de significado. Otros autores han criticado este punto de vista intentando mostrar que hay palabras que son tanto conceptuales como procedimentales (Fraser 2006): por ejemplo, se ha dicho que en numerosos marcadores, del tipo de por consiguiente, en consecuencia y no obstante, debe subsistir una porción de significado conceptual. Recientemente, Wilson (2011) ha sostenido que la visión de la distinción en la Teoría de la Relevancia no es en modo alguno incompatible con esta última posibilidad, y que de hecho postular que los dos tipos de significado puedan coexistir bajo una misma entrada léxica puede ayudar a entender mejor ciertos datos, como las conocidas diferencias de orientación argumentativa entre poco y un poco, ya señaladas por O. Ducrot: las dos expresiones podrían compartir un contenido conceptual básico de cantidad limitada, y diferir en sus rasgos procedimentales. Wilson (2011) retoma además una propuesta original de D. Sperber, en lo esencial coincidente con la postura de R. Kempson mencionada anteriormente y con las ideas de Anscombre y Ducrot, según la cual todas las palabras codifican instrucciones en algún sentido. Este supuesto está ligado a las investigaciones que se han desarrollado en el campo de lo que se denomina Pragmática léxica (el estudio de los procesos pragmáticos que se activan en la interpretación de los elementos léxicos con contenido conceptual): así como en la Teoría de la Relevancia el papel del significado lingüístico de un enunciado no es el de codificar el contenido comunicado por el hablante, sino proporcionar al oyente pruebas de su intención comunicativa, el papel de las palabras con significado conceptual no consiste exactamente en codificar un concepto, sino en ofrecer un esquema o una indicación del concepto que se pretende comunicar. De esta forma es 
posible afrontar el problema básico de la variación contextual del significado léxico (por ejemplo, el problema de cómo es posible que crudo no signifique lo mismo en todos los contextos en los que se usa). El concepto pleno que la palabra consigue expresar cuando es usada en un contexto - lo que a menudo se denomina concepto ad hoc- se obtiene al desarrollar inferencialmente el esquema incompleto y parcial codificado por el elemento léxico. De aquí a suponer que lo que las palabras conceptuales codifican son instrucciones solo hay un paso: se trata de instrucciones para activar y construir inferencialmente un concepto ad hoc explotando la información contextual disponible.

Este punto de vista es más bien especulativo, por el momento, y suscita un buen número de preguntas sobre la naturaleza del significado léxico que, obviamente, no pretendemos examinar ahora. Lo importante es que conduce a Wilson a aceptar, por un lado, que muchas palabras pueden ser al mismo tiempo procedimentales y conceptuales, y, por otro, que todas las palabras codifican instrucciones en algún sentido (no necesariamente del mismo tipo en todos los casos: véase Curcó 2011 para una sugerencia que se aparta de la propuesta de Wilson, y más adelante, 3.2).

\section{Perspectivas}

La conclusión inmediata que se obtiene después de un rápido repaso a tres modelos teóricos que han explotado la noción de significado procedimental es que se produce una coincidencia llamativa y sorprendente entre ellos: en todos se acaba extendiendo la idea, por diversos motivos, a la totalidad de las piezas léxicas, en contra de lo inicialmente establecido. La tendencia resultante refleja un vuelco radical para las teorías tradicionales del significado: la identificación clásica del significado léxico con los conceptos no solo se ve limitada por la existencia de palabras cuyo contenido lingüístico es puramente procedimental (sin restos de contenido conceptual), sino que incluso resulta afectada por la irrupción del significado procedimental en las categorías léxicas más claramente conceptuales, es decir, los nombres, los adjetivos y los verbos. No es fácil prever hacia dónde nos pueden llevar en el futuro las propuestas que hemos reseñado. Por el momento, nos limitaremos a comentar algunos puntos que pueden perfilar algo mejor el alcance de ciertas hipótesis. 


\subsection{La distinción sigue en pie}

La separación entre significado conceptual y significado procedimental parece difuminarse por completo tanto en las últimas versiones del enfoque de Anscombre y Ducrot, donde todas las expresiones se asocian con instrucciones, como en el de Kempson y en el de Sperber y Wilson, donde las palabras conceptuales son a la vez también procedimentales. Ante una situación como esta es quizá natural pensar que la distinción original se ha abandonado o está en vías de desaparición. Sin embargo, creemos que, por un lado, la distinción debe mantenerse, por múltiples razones que no podemos enumerar aquí (cf. Leonetti y Escandell-Vidal 2004, Escandell-Vidal y Leonetti 2011, Curcó 2011, Saussure 2011), y por otro lado, sigue siendo compatible con la reciente tendencia a la generalización de lo procedimental. Para entender este último punto, es fundamental precisar que en ningún momento se ha propuesto que deba existir una mezcla indiscriminada de conceptos e instrucciones. Parece claro que esto no nos llevaría muy lejos. Lo más razonable, por el contrario, es adoptar una visión más restrictiva y suponer que si hay contenido de los dos tipos en una misma palabra, debe estar ordenado jerárquicamente. Siguiendo a Saussure (2011: 60-66), si las instrucciones definen operaciones sobre representaciones conceptuales, pero los conceptos no pueden operar sobre las instrucciones, como es bien sabido, es lógico pensar que las instrucciones deben ser jerárquicamente superiores o previas a los estratos de representaciones conceptuales. Concretamente, lo conceptual debe estar subordinado a lo procedimental, y actuar como un parámetro que lo especifique: es la función, por ejemplo, del contenido de género en un pronombre personal como ella, que es una unidad procedimental; lo mismo sucede en algunos marcadores del discurso, como el francés puisque, donde el concepto básico de 'causa' está incrustado en una instrucción que obliga a tomar la oración subordinada como información consabida o mutuamente manifiesta. Las expresiones supuestamente «mixtas» son, pues, esencialmente procedimentales. Además, la combinación de instrucciones y conceptos bajo una misma entrada léxica debe tomarse, según Saussure (2011: 60), como un caso marcado y excepcional.

Por otra parte, no está claro cómo debe entenderse la afirmación de Kempson y Wilson de que todas las palabras, incluso las conceptuales, contienen instrucciones. No parece que esas instrucciones para elaborar conceptos ad hoc se puedan identificar con las instrucciones específicas de 
los elementos propiamente procedimentales. Debería tratarse más bien de procedimientos no específicos de cada palabra que reflejan simplemente el funcionamiento de principios pragmáticos generales (Saussure 2011: 6364), o quizá de «disposiciones causales» atribuibles al sistema pragmático (Curcó 2011: 48-50). Son los principios pragmáticos generales, y no los rasgos codificados en cada palabra, los responsables de los procesos de modulación contextual del significado léxico. No deben confundirse las inferencias resultantes de estos principios generales con las inferencias específicamente activadas y controladas por los elementos procedimentales, ya que lo característico de estas últimas es precisamente que no pueden derivarse de principios generales. De ello se deduce que si el contenido conceptual también lleva asociadas instrucciones interpretativas, desde luego no son equiparables a lo genuinamente procedimental, por lo que la generalización de la noción de 'significado como instrucciones' a todas las piezas léxicas debe tomarse con muchas precauciones. La conclusión es que la distinción original no se difumina en absoluto, ni siquiera asumiendo que puede haber contenidos de los dos tipos en una misma palabra.

\subsection{Procedimental y argumentativo}

En ciertas ocasiones se ha criticado la distinción conceptual / procedimental argumentando que todos los elementos lingüísticos generan inferencias pragmáticas a lo largo del proceso interpretativo, y que en ese sentido cualquier elemento conceptual es capaz de restringir los esquemas de inferencia y la orientación argumentativa (cf. la diferencia entre tener, acarrear y atesorar comentada en Portolés 2004: 273). De nuevo conviene hacer algunas aclaraciones a favor del carácter nítido de la distinción.

Es cierto - y trivial — que cualquier elemento lingüístico dotado de significado orienta en cierto sentido la interpretación. No obstante, como ya hemos recordado anteriormente, no se debe confundir el conjunto de inferencias ligadas al procesamiento de un término conceptual con el conjunto de inferencias controladas y activadas por un término procedimental. Las primeras derivan de la acción de principios generales y de la interacción de los rasgos conceptuales con la información contextual, y por supuesto pueden afectar a la orientación argumentativa. Sin embargo, esto no implica que se deban a instrucciones codificadas como parte del significado. Las inferencias controladas por un elemento procedimental, en 
cambio, sí están restringidas por instrucciones específicas. En consecuencia, la orientación argumentativa no siempre está determinada por instrucciones codificadas, y por lo tanto no es lícito postular una conexión sistemática entre lo primero y lo segundo. Valor argumentativo no implica necesariamente contenido procedimental. Esta es la razón por la que las conclusiones alcanzadas en la teoría de Anscombre y Ducrot sobre la orientación argumentativa no pueden traducirse automáticamente a conclusiones sobre semántica procedimental en la teoría de Sperber y Wilson.

\section{El estatuto de la semántica procedimental}

Las aportaciones que hemos revisado permiten concluir que hoy la idea de significado procedimental está sólidamente asentada en varias teorías lingüísticas. Esta noción ha tenido una importancia decisiva en el desarrollo de tales teorías y ha contribuido a arrojar luz sobre muchos fenómenos gramaticales y discursivos. Su papel ha sido tan destacado que en la actualidad podemos manejar hipótesis más precisas y explícitas sobre la codificación de instrucciones que sobre la codificación de datos conceptuales. A ello ha contribuido también el hecho de que el significado procedimental ha resultado más fácil de capturar en los modelos formales, incluso en el caso de los contenidos no veritativos. Como ya sugeríamos en Leonetti y Escandell-Vidal (2004: 1732), «la semántica procedimental es la semántica lingüística en estado puro». No está vinculada a contenidos representacionales, ni al conocimiento enciclopédico. Es la semántica conceptual, inevitablemente "contaminada» por el conocimiento del mundo, la que representa el terreno más oscuro e inseguro para el análisis. Algo difícilmente imaginable hace unas décadas...

\section{Referencias}

Anscombre, J.-C. y O. Ducrot (1983): L'argumentation dans la langue, Bruselas, Mardaga.

Ariel, M. (2010): Defining Pragmatics, Cambridge, Cambridge University Press. Blakemore, D. (1987): Semantic Constraints on Relevance, Oxford, Blackwell. Curcó, C. (2011): «On the Status of Procedural Meaning in Natural Language», en Escandell Vidal, Leonetti y Ahern (eds.) (2011): 33-54. 
Escandell-Vidal, M. V. y M. Leonetti (2000): «Categorías funcionales y semántica procedimental», en M. Martínez Hernández et al. (eds.), Cien años de investigación semántica: de Michel Bréal a la actualidad, Madrid, Ediciones Clásicas: 363-378.

- (2011): "On the Rigidity of Procedural Meaning», en Escandell-Vidal, Leonetti y Ahern (eds.) (2011): 81-102.

- M. Leonetti y A. Ahern (2011): «Introduction: Procedural meaning», en Escandell-Vidal, Leonetti y Ahern (eds.) (2011): xvii-xviii.

- M. Leonetti y A. Ahern (eds.) (2011): Procedural Meaning: Problems and Perspectives, Bingley, Emerald.

Espinal, M. T. (1996): "On the Semantic Content of Lexical Items within Linguistic Theory», Linguistics, 34: 109-131.

Fraser, B. (2006): "On the Conceptual/Procedural Distinction», Style, 40.

Iten, C. (1999): «The Relevance of Argumentation Theory», UCL Working Papers in Linguistics, 11: 41-79.

Kempson, R. (2000): «Pragmatics: Language and Communication», en Aronoff, M. y J. Rees-Miller (eds.), The Handbook of Linguistics, Oxford, Blackwell: 394-427.

Kempson, R., R. Cann y M. Purver (en prensa): «Talking and Listening: Dialogue and the Grammar-Pragmatics Interface», en M. Hackl y R. Thornton (eds.), Asserting, Meaning and Implying, Oxford, Oxford University Press.

Leonetti, M. y V. Escandell-Vidal (2004): «Semántica conceptual/Semántica procedimental», en M. Villayandre Llamazares (ed.), Actas del V Congreso de Lingüistica General, Madrid, Arco: 1727-1738.

Portolés, J. (2004): Pragmática para hispanistas, Madrid, Síntesis.

Saussure, L. (2011): «On Some Methodological Issues in the Conceptual/Procedural Distinction», en Escandell-Vidal, Leonetti y Ahern (eds.) (2011): 55-79.

Sperber, D. y D. Wilson (1986): Relevance, Oxford, Blackwell.

Thagard, P. (2005): Mind: Introduction to Cognitive Science, 2. ${ }^{\mathrm{a}}$ ed., Cambridge (Mass.), MIT Press.

Wilson, D. (2011): «The Conceptual-Procedural Distinction: Past, Present and Future», en Escandell-Vidal, Leonetti y Ahern (eds.) (2011): 3-31. 



\title{
ENTRE KUFA Y BASORA: NOMBRES, VERBOS Y RAÍCES
}

\author{
Antonio FÁbregas \\ (IS, Universitet i Tromsø)
}

\section{Una historia antigua con connotaciones modernas}

La rivalidad que se establece en la actualidad entre las escuelas lingüísticas no es precisamente nueva. En la época de Harun al-Rashid, Bagdad fue la sede de un debate entre los máximos representantes de las dos escuelas lingüísticas más importantes de la época, enfrentadas hasta el extremo: la escuela de Kufa y la de Basora. En el rincón de la izquierda, nacido en Kufa y representando a la escuela epónima, se encontraba Kisa’i, que, por cierto, era el tutor de los hijos de Harun al-Rashid. En el rincón de la derecha, nacido en Bayza (Persia) y como representante de la escuela de Basora, Sibawaih. Las peleas entre ambas escuelas habían llegado al punto de que lo que Basora dictaba como una regla era rápidamente negado por Kufa mediante el hallazgo de varias excepciones tomadas de la lengua de algunas tribus beduinas, que los kufíes, automáticamente, convertían en el patrón para dictar una regla distinta, de sentido opuesto a la de Basora. Es posible que esto resulte familiar; es posible que no.

No tenemos demasiados datos reales sobre este debate, que al parecer trató en buena parte sobre el uso correcto de las formas de pasado, pero sí sabemos cómo acabó. Al parecer, el visir Yajya Ibn Jalid, al que Harun 
al-Rashid había encargado organizar todo, recibió indicaciones superiores de que no se vería con buenos ojos que el tutor de los hijos del califa perdiera el debate, y al parecer el tribunal — formado en su mayoría por beduinos de las tribus del Nadid, Hiyaz y Tihama - recibió ciertos incentivos especiales para votar a favor de Kita'i y declararlo vencedor. Otros dicen que el soborno no fue necesario, porque estas eran precisamente las tribus con las que Kita’i había estudiado la lengua árabe; es decir, en términos modernos, eran sus propios informantes y naturalmente tendían a estar de acuerdo con los datos que ellos mismos le habían dado a Kita’i, y sobre los que precisamente iba el debate. Sea como fuere, Sibawaih perdió el torneo por votación mayoritaria, se fue de Bagdad y según algunos el disgusto fue tan grande que anticipó su muerte.

Este debate suele citarse frecuentemente —al menos, tan frecuentemente como suelen citarse los incidentes lingüísticos- como un ejemplo de juego sucio en ciencia, y la reputación de Kisa’i ha quedado asociada a este episodio para siempre. Incluso recientemente, por ejemplo en la Enciclopedia del Islam, en el artículo sobre Kisa'i se afirma, de pasada y sin que sea estrictamente necesario hacerlo, que pese a la opinión de sus contemporáneos, este autor tenía un conocimiento superficial de la gramática, que comenzó a estudiar tarde. Es posible que en esta opinión moderna influya el hecho de que en la actualidad los volúmenes de la gramática de Sibawaih (el Kitab) se consideran canónicos y por tanto se supone que él debería haber ganado el debate.

Este ejemplo viene al caso por el aspecto gramatical en el que más claramente contrastaban las propuestas de Kufa y de Basora: ¡cuál es la forma básica de una palabra? Como es bien sabido, en la morfología semítica hay dos clases bien diferenciadas de unidades con propiedades morfológicas, fonológicas y semánticas bien distintas. Por un lado, tenemos raíces (en su mayor parte formadas por tres consonantes), carentes de categoría y con una semántica muy subespecificada; por otro lado, tenemos patrones morfológicos (binyanim en hebreo y 'awza: $n$ en árabe), formados fundamentalmente por vocales largas y breves, que se intercalan entre las consonantes de la raíz para darle a esta una categoría y un significado específico. La raíz nunca puede aparecer sola; desde un punto de vista fonológico, es casi impronunciable en aislamiento; por su significado, carece de uno determinado hasta que se combina con un binyan; en su 
sintaxis, no pertenece a ninguna clase de palabras. Por ejemplo, a partir de la misma raíz triconsonántica, $\sqrt{K T B}_{\mathrm{KT}}$, surgen distintas palabras, algunas de ellas nombres (entre las que destaca el masdar, que ahora llamaríamos 'nombre de evento') y algunas de ellas verbales. No mencionamos los adjetivos en aras de la simplificación.

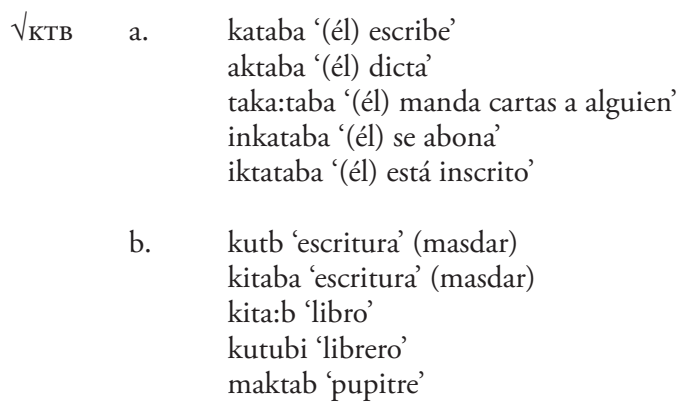

Pese a que la raíz mantiene habitualmente cierto núcleo conceptual, en los ejemplos de (1a), todos verbales, y los de (1b), todos nominales, se observa que el significado final de la palabra es concretado siempre por el wazn.

Aunque ambas escuelas aceptaban que las formas se construían sobre una raíz subespecificada, la cuestión sobre la que se debatió fue si los awzan verbales derivaban los nominales o viceversa, sobre todo en la cuestión de si la forma llamada masdar, que ahora llamaríamos 'nombre de acción' o 'nombre de evento', era más o menos básico que el verbo. Esta era la vieja pregunta sobre cómo se relacionan las categorías gramaticales entre sí, cuestión que, como veremos, sigue estando abierta a debate en la actualidad.

La escuela de Kufa proponía que las formas verbales eran el origen del masdar y las otras formas nominales que tuvieran un componente de acción en su significado. Su argumento es que el verbo expresa la acción, y la mente humana puede aprehender la acción (digamos, atacar) antes que el nombre abstracto que se usa para referirse a ella (digamos, ataque). La escuela de Basora, como no podía ser de otro modo, proponía lo contrario: el wazn nominal es más básico que el wazn verbal, porque el nombre de acción (ataque) designa lo mismo que el verbo (atacar), solo que en una forma más básica y desprovista de aditivos, carente del ligado temporal y 
aspectual. Como se ve, el debate se centró en aspectos semánticos, lo cual no es ninguna sorpresa — ni ninguna reliquia — en los estudios lingüísticos. En el pasado, Aristóteles había utilizado el mismo criterio, y en la actualidad, autores como Langacker (2000) utilizan aún criterios fundamentalmente conceptuales para definir las categorías y las relaciones que se establecen entre ellas.

Estas ideas, sin embargo, han perdurado hasta la actualidad, aunque en otra forma. En el resto de este trabajo mostraremos cómo los puntos de acuerdo y desacuerdo entre Kufa y Basora siguen siendo parte activa del debate sobre la definición de las categorías gramaticales y la relación entre morfología y sintaxis, y cómo sus acuerdos y sus desacuerdos siguen estando presentes en los debates lingüísticos.

\section{La herencia de Kufa y Basora en odres nuevos}

Kufa defendía que el nombre de acción viene derivado del verbo; es decir, la estructura verbal está completa y sobre ella se deriva un sustantivo. Esta idea, con modificaciones técnicas, está en la base de dos tipos de aproximación a la gramática de los nombres de acción: la propuesta de Lees (1960), en el marco de la semántica generativa, y, con matices diferentes, la propuesta de Grimshaw (1990) en el marco de la morfología lexicalista.

La idea de Lees es notablemente similar a la de la escuela de Kufa: semánticamente, un nombre de acción es la forma de manifestar dentro de la categoría nominal las mismas nociones semánticas que transmitimos con una oración completa, incluyendo información sobre la estructura argumental, el aspecto y el tiempo. Simplificando los aspectos técnicos un poco y traduciendo la estructura de Lees a una notación más moderna, su idea es que sobre una proyección equivalente por su significado a una oración completa se construye un sustantivo (2).

$[\mathrm{SN}$

[SC

$[\mathrm{ST}$

[SV]]]]

No parece justo, para establecer la comparación, utilizar argumentos morfofonológicos a favor o en contra de una teoría, ya que la materialización de las piezas léxicas es radicalmente distinta en las lenguas semíticas y 
en las indoeuropeas. Basta, sin embargo, observar la estructura de (2) para observar algunos de sus problemas, que sí podrían extenderse a la propuesta de Kufa, porque no se apoyan sobre la morfofonología. Una de ellas es por qué, si los nombres de acción contienen tiempo, no contienen morfemas temporales (frente a morfemas aspectuales, que sí se observan en el interior de una nominalización, por ejemplo, en las lenguas eslavas). Sin embargo, la propuesta no está exenta de ventajas. Uno de los problemas abiertos en el estudio de los nombres de acción es por qué permiten — cuando hay modificadores de tiempo dependiendo de ellos- que su anclaje temporal no sea idéntico al del verbo de la oración en la que aparecen, como se ve en (3).

[Las declaraciones el martes del ministro del interior] despertaron una fuerte protesta el jueves, cuando se filtraron a la prensa.

Notablemente, en (3) no se sigue que la acción de despertar una fuerte protesta y la de declarar sucedieran en el mismo punto temporal; la presencia de los modificadores de tiempo fuerza a que se interpreten como sucedidas en distintos momentos, lo cual es perfectamente posible.

La presencia de complementantes, que en la moderna teoría sintáctica se consideran el elemento que encabeza toda oración que pueda constituir un enunciado, tiene similares ventajas y desventajas a la idea de que las nominalizaciones contienen tiempo. Por un lado, cabe preguntarse por qué no aparecen morfemas de complementante en el interior de las nominalizaciones - aunque debe decirse que en ciertas lenguas esto es posible, como en turco, sin que de forma obvia la nominalización se comporte externamente como una oración subordinada - Por otro lado, parece claro que las nominalizaciones pueden expresar valores ilocutivos, dependiendo del valor modal del predicado principal. En (4a), la acción se interpreta factivamente; en (4b), como irrealis; en (4c), como realis.
a. [La destrucción de la ciudad] es lamentable.
b. [La destrucción de la ciudad] es deseable.
c. [La destrucción de la ciudad] causó muchos muertos.

La propuesta de Grimshaw fundamentalmente se enmarca dentro de la tradición de Kufa. Aunque en su análisis los nombres de acción carecen de tiempo y de aspecto, sí contienen una estructura argumental que procede directamente del verbo. Así, si un nombre de acción como destrucción 
puede llevar los modificadores que marcamos en (5), esto se debe a que está construida sobre un verbo que define una estructura argumental en el léxico.

la destrucción de la ciudad por parte del ejército enemigo desde tierra, mar y aire

Un problema que se ha encontrado a este argumento, sin embargo, es que se basa sobre todo en una noción semántica conceptual, y en ese mismo sentido semántico y conceptual otros nombres no relacionados con verbos pueden llevar modificadores semánticamente equivalentes, aunque la preposición empleada tiene que ser distinta en lenguas como el español, lo cual tal vez marque una diferencia profunda que confirme la distinción establecida por Grimshaw. En efecto, cuadro puede llevar un modificador que indica el paciente, otro para el agente y otro para el lugar en que se localiza.

el cuadro de Carlos IV de Goya del Museo del Prado

Otras teorías modernas caen más bien del lado de Basora. Entre ellas destacan las de Alexiadou (2001) y Borer (2010), que se apoyan más en lo que a un nombre de acción le falta para ser un verbo pleno que en lo que tiene de él. Ambas teorías parten de la idea de que un nombre de acción es una parte (relativamente pequeña) de la estructura que normalmente se manifiesta como un verbo. A esa estructura, generalmente, se le ha eliminado el tiempo, el modo, las proyecciones que legitiman al complemento directo e incluso la proyección que cierra la estructura argumental introduciendo el agente. Alexiadou destaca la relación que tiene una nominalización con un verbo inacusativo, que carece de agente y cuyo único argumento no puede recibir caso en el interior del sintagma verbal. En (8) se observa que lo que en la versión verbal puede aparecer como acusativo (8a) debe manifestarse como genitivo - caso prototípicamente nominal- en (8b) y que el agente no es obligatorio (cf. 8b), pero cuando aparece (8c) se realiza igual que en una voz pasiva (8d). Estas equivalencias sugieren que la estructura verbal ha sido recortada y la nominalización implica la supresión de estructura verbal, como decía también la escuela de Basora.
a. Juan asesinó a Pedro
b. el asesinato de Pedro
c. el asesinato de Pedro por Juan
d. Pedro fue asesinado por Juan 
Borer (2010) cae más aún en el modelo de Basora, en tanto que llega al extremo de proponer que ciertas nominalizaciones se obtienen cuando se reduce la estructura verbal a un mínimo, que elimina incluso la estructura argumental, y en tales casos no es necesario ni siquiera nominalizar; la estructura puede combinarse directamente con proyecciones funcionales del sustantivo, como el número y los clasificadores nominales, porque ha perdido casi por completo su naturaleza verbal. (9a) muestra que ciertas nominalizaciones del inglés, aun siendo eventivas en su significado - como muestra la compatibilidad con el predicado take place - no pueden llevar estructura argumental (9b), pero sí número (9c); como se ve, no hay morfema alguno que corresponda en este caso al nominalizador.
a. The parade took place at noon. el desfile tuvo lugar a mediodía
b. *the parade by the soldiers for several hours *el desfile por los soldados durante varias horas
c. Military parades always take place at noon militares desfiles siempre tienen lugar a mediodía
'Los desfiles militares siempre tienen lugar a mediodía'

\section{Tendiendo un puente entre Kufa y Basora}

Hay dos formas en las que Kufa y Basora podrían haber empatado: ambas se equivocaban o ambas tenían razón. En esta sección vamos a explorar cómo estas coincidencias se pueden plasmar en la actualidad.

Una de las ideas en las que estaban completamente de acuerdo es la noción de que la raíz siempre es previa al wazn; una posibilidad sería decir que ambas escuelas se equivocaban en intentar derivar un wazn del otro y que en ambos casos las formas se derivaban directamente de la raíz. Esta propuesta ha sido enunciada modernamente como el análisis no direccional de la conversión: la forma nominal no viene de la verbal, y la verbal no viene de la nominal. Ambas formas son primitivas (Lieber 1980) o, más en la línea que une a Kufa y Basora, ambas formas derivan directamente de la raíz, sin pasar por una forma intermedia, como se representa en (10).
a. $[\mathrm{N} \quad[\sqrt{ }]]$
-e atak-
b. $\left[\begin{array}{ll}\mathrm{V} & {[\sqrt{ }]}\end{array}\right]$
-a atak- 
Esta forma se ha empleado modernamente para evitar un problema en el que tanto Basora como Kufa caen: el criterio semántico para determinar la dirección de un proceso morfológico. Dicho de otro modo, ¿es atacar la acción de realizar un ataque, o, por el contrario, es ataque lo que se produce cuando se ataca? Este problema, que surge cuando la dirección de un proceso no es obvia desde el punto de vista formal, se repite infinidad de veces: ¿es una compra lo que se obtiene de comprar o es comprar la acción de hacer compras?; ¡es un baile lo que sale cuando se baila o es bailar la acción de hacer un baile? Este enigma, de difícil resolución práctica, desaparece si admitimos que ambas formas vienen derivadas de la misma raíz, como en (10), y ninguna debe contener el significado de la otra.

Sin embargo, para cerrar el artículo, querríamos defender brevemente otra posibilidad distinta que también une a Kufa y Basora, pero por sus aciertos más que por sus errores y, de paso, explica una diferencia entre distintas clases de nominalizaciones cero. Existe la posibilidad de que tanto unos como otros tuvieran razón, y, dependiendo de cada raíz, su historia derivativa la haga pasar — en unos casos- primero por ser nombre y luego por ser verbo y —en otros casos - cubrir el recorrido contrario. Uno de los puntos de debate entre las dos escuelas era precisamente que la relación entre los 'awza:n que explicaban elegantemente el paso de una a otra para una raíz requerían idiosincrasias y reglas extrańas para explicar ese mismo paso con otra raíz. Bien pudiera ser que la dirección no fuera siempre la misma, y eso es precisamente lo que trataremos de defender brevemente en esta sección tomando casos de nominalizaciones cero (tipo ataque) en espańol. Este caso es significativo, porque el sustantivo y el verbo contrastan superficialmente solo en que la desinencia sustituye a la vocal temática (o viceversa, naturalmente). Por ello, en estos casos no hay pistas morfofonológicas que pudieran inclinarnos por una de las dos derivaciones. Al mismo tiempo, estos ejemplos resultan significativos porque son casos muy comunes en español, en absoluto excepcionales. Nuestra propuesta es que nombres como los de (11) son kufíes, es decir, hacen lo que Kufa predice, ya que parecen ser nombres deverbales. Los que son como (12), en cambio, son basríes, porque en ellos el nombre es más básico que el verbo.

ataque, acuerdo, siembra, compra, desguace, transporte, reconquista, abandono baile, asiento, cuento, carga, choque, galope, toque, roce, mordisco, insulto 
¿Cómo sabemos esto? La diferencia fundamental entre (11) y (12) es que los nombres de (11) admiten estructura argumental como los verbos. Preposiciones como por en interpretación de agente o las preposiciones locativas hacia, para, en y hasta, son siempre rechazadas por los nombres que no se relacionan con verbos, aunque denoten eventos (13), lo cual indica que cuando aparecen, lo hacen porque están legitimadas por un verbo (14).

Pues bien: los nombres de (11) legitiman estas preposiciones (cf. 15), pero los de (12), no (cf. 16). Esto indica que los nombres de (11) son deverbales y en ellos hay que seguir una derivación de Kufa (verbo > nombre), mientras que los de (12) siguen la derivación que hubiera complacido a Sibawaih (nombre $>$ verbo).

\section{el ataque a los judíos por los alemanes en Europa}

*el baile de la polka por Eleuteria en su habitación

Si queremos traducir esto a términos más conceptuales, como los manejados por las dos escuelas lingüísticas, la idea sería que raíces como $V_{\text {ATAK- se asocian a nociones que los hablantes ven más como acciones que }}$

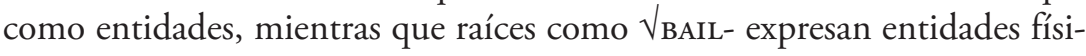
cas que luego pueden emplearse para definir acciones. Esto, naturalmente, debe tomarse en términos muy intuitivos, ya que hemos observado que una raíz no tiene una semántica muy definida y debe combinarse con otros elementos para obtener un significado completo, por lo que probablemente es una simplificación asociar directamente raíces con significados.

Sin embargo, el procedimiento que hemos seguido no ha sido conceptual, sino formal: ciertas preposiciones — no las nociones conceptuales que introducen - solo son posibles como modificadores nominales cuando están legitimados por estructura verbal. Este es, probablemente, el aspecto más destacado que ha sido modificado de manera sustancial desde los tiempos de Kufa y Basora: en la actualidad, la metodología que se utiliza no es simplemente conceptual (aunque las aportaciones conceptuales no se rechazan y siguen ocupando un lugar central en una buena parte de las escuelas lingüísticas actuales), sino que trata de considerar al mismo tiem- 
po los aspectos formales de cómo esos conceptos se manifiestan a través de marcas morfológicas, categorías gramaticales y operaciones formales de concordancia, régimen o desplazamiento. Es verdad que no hay mucho nuevo bajo el Sol, pero también es verdad que la forma de presentar y argumentar las ideas antiguas se ha hecho algo más sofisticada, prestando más atención a rasgos de lenguas tipológicamente remotas y enunciando teorías sobre bases más tangibles que la mera predisposición de la mente humana a considerar más básicas las acciones abstractas o las acciones ligadas temporalmente.

\section{Conclusiones}

Ya acabamos. Creemos que de este estudio pueden salir inmediatamente dos conclusiones, que probablemente sean obvias. La primera es que es difícil que una idea sea completamente nueva, al menos enunciada en su forma más intuitiva; las diferencias surgen cuando observamos los detalles y, sobre todo, cuando controlamos la metodología que se emplea para defenderla. La segunda conclusión puede parecer una moraleja: cuando hay un debate científico que dura más de cinco minutos, suele ser porque los dos bandos tienen algo de razón y tal vez el esfuerzo pueda conducirse de forma hábil si se trata de encontrar algún punto común de acuerdo sobre la naturaleza de los datos que vaya más allá de los lenguajes técnicos particulares que cada teoría propugna. No llegamos a tiempo de estar en aquel tribunal de Bagdad, y tampoco parece que nadie hubiera estado satisfecho si se hubiera declarado un empate, pero a juzgar por los datos en español actual, habrían acabado en tablas.

\section{Referencias}

Alexiadou, A. (2001): Functional Structure in Nominals: Nominalizations and Ergativity, Ámsterdam/Nueva York, John Benjamins.

Bearman, P. J., Th. Bianquis, C. E. Bosworth, E. van Donzel y W. P. HeinRICHS (eds.) (1962-2005): Encyclopaedia of Islam, Leiden, E. J. Brill.

Borer, H. (2010): «In the event of a nominal», ejemplario de una ponencia invitada en Workshop on Verb Meaning, Event Semantics and Argument Structure, Universidad Autónoma de Barcelona, 2-3 de diciembre de 2010. 
Grimshaw, H. (1990): Argument Structure, Cambridge (Mass.), MIT Press.

Langacker, R. (2000): Grammar and conceptualization, Berlín, Mouton de Gruyter.

Lees, R. B. (1960): The grammar of English Nominalizations, La Haya, Mouton de Gruyter.

Lieber, R. (1980): On the Organization of the Lexicon, tesis doctoral, Cambridge (Mass.), MIT. 



\title{
EN EL PRINCIPIO ERA EL VERBO. LA CATEGORÍA VERBAL EN LAS OBRAS DE PORT-ROYAL ${ }^{1}$
}

\author{
María del Carmen Horno Chéliz \\ (Universidad de Zaragoza)
}

No deja de ser sintomático de la formación que una ha recibido del maestro que aquí nos reúne, el hecho de que, ante la perspectiva de hacer un trabajo de historiografía, haya elegido volver los ojos a los gramáticos de Port-Royal. No es, obviamente, que desconozca las ventajas del trabajo empírico. Las reconozco, como todos los que actualmente tratamos de hacer ciencia, y no evito el trabajo corpóreo (de corpus) de los datos. Será precisamente por eso, por vivir habitualmente en el terreno de las verdades probables de la ciencia empírica, que una siente tanto placer al volver al mundo de las verdades absolutas y necesarias de los maestros franceses.

Volvamos, pues, a Port-Royal una vez más. Si hay algo que destaca de los estudios lingüísticos que nos aportan estos autores en sus obras ${ }^{2}$ es que en ellas no quieren dar pautas de conducta (alejándose, así, de las obras normativas, tan frecuentes, por otra parte), ni tampoco se limitan a describir los hechos gramaticales. Por el contrario, su ambición es tal que tratan de enten-

1 Este trabajo se encuadra dentro del proyecto $M o v E s$, financiado por el Ministerio de Ciencia e Innovación del Gobierno de España (FFI2010-14903).

2 La teoría del verbo aparece tanto en la gramática como en la lógica sin modificaciones importantes, por lo que hablamos de «las obras de Port-Royal» en general. 
der los motivos por los que los hechos lingüísticos 'son lo que son'. ${ }^{3}$ El lector del siglo XXI encuentra así en estas obras una reflexión más que interesante sobre la relación entre la lógica y la gramática. Sirva de ejemplo para mostrar esto la caracterización que estos autores dan de la categoría verbal.

Los maestros de Port Royal se proponen dar una definición de verbo. Conscientes de su labor, repasan las definiciones que otros dieron y las rechazan una a una bien por exceso (entran en la categoría más elementos de los que deberían), bien por defecto (no entran en la definición algunos elementos que deberían estar). Por este doble motivo, rechazan la definición de verbo como elemento temporal. De este modo, lejos de las caracterizaciones al uso, donde el verbo es definido en virtud de su adscripción temporal o aspectual, los autores de Port-Royal afirman que:

Et c'est proprement en quoi consiste ce que l'on appelle verbe, qui n'est rien autre qu'un mot dont le principal usage est de signifier l'affirmation, c'est-àdire, de marquer que le discours où ce mot est employé, est le discours d'un homme qui ne conçoit pas seulement les choses, mais qui en juge et qui les affirme (Arnauld y Lancelot 1660/1968: 175-176).

Como podemos ver en la cita anterior, la caracterización de una categoría gramatical se convierte en estas obras en una teoría gramatical en sí misma. A lo largo de las breves páginas que componen esta contribución, trataremos de mostrar las implicaciones teóricas que podemos extraer de esta definición. Y, a partir de ahí, nuestro propósito es reconsiderar algunos de los temas de la lingüística actual. ¿Hasta qué punto la definición de verbo de los maestros franceses nos ayuda a entender problemas actuales de la ciencia lingüística?

\section{Estructura profunda frente a estructura superficial}

Basados en la reflexión anterior, los autores de Port-Royal distinguen entre «verbo sustantivo», esto es, la cópula, definida como «un mot qui signifie

3 Una posible explicación de que la gramática de Port-Royal supere la descripción y la prescripción gramatical es, según Donzé (1970), el tipo de público al que va dirigido. Un público culto, que conoce varias lenguas clásicas y es capaz de entender una gramática de este tipo: «Con destino a este lector, Arnauld y Lancelot han pensado con razón que entre la tendencia descriptiva o normativa de las Observaciones, de las Dudas, de las Recomendaciones, había lugar para una gramática explicativa fundada en el procedimiento de la demostración» (Donzé 1970: 15). 
l'affirmation" (Arnauld y Lancelot 1660/1968: 180) y "verbo adjetivo», que responde a la unión de la cópula con el atributo y se define como «un mot qui marque l'affirmation de quelque attribut, avec designation de la personne, du nombre et du temps» (Arnauld y Lancelot 1660/1968: 181). Ante esto, llegan a la conclusión de que, si lo más propio del verbo es la afirmación, el verbo más puro es el verbo ser en tercera persona en presente, voz activa y modo indicativo. Y que al resto se le han ańadido elementos ajenos al propio verbo:

Si l'on s'était contenté de donner au verbe la signification générale de l'affirmation, sans y joindre aucun attribut particulier, on n'aurait eu besoin, dans chaque langue, que d'un seul verbe, qui est celui qu'on appelle substantif (Arnauld y Lancelot, 1660/1968: 176-177).

Como siglos más tarde reconocería el fundador de la Gramática Generativa, en las palabras del párrafo anterior encontramos un precedente indudable de la distinción formal entre la estructura profunda, ligada a la interpretación semántica de las oraciones, y la estructura superficial, más ajustada a la información morfológica y fonológica de los enunciados:

In short, language has an inner and an outer aspect. A sentence can be studied from the point of view of how it expresses a thought or from the point of view of its physical shape, that is, from the point of view of either semantic interpretation or phonetic interpretation.

Using some recent terminology, we can distinguish the «deep structure» of a sentence from its «surface structure». The former is the underlying abstract structure that determines the phonetic interpretation and which relates to the physical form of the actual utterance, to its perceived or intended form (Chomsky 1966: 33).

4 Hemos de advertir que, pese a la gran importancia de Port-Royal, su definición de verbo no es en absoluto original, pues se puede encontrar en otras obras de la época. Y no solo nos referimos a autores influidos por las obras de Port-Royal, como Benito de San Pedro (véase, al respecto, Lliteras 1992). Seis años antes de la publicación de la Gramática de Port Royal, en 1654, Caramuel escribía: «Mal se define al verbo cuando se dice que «significa tiempo», puesto que también siglo, edad, olimpíada, año, mes, día, hora, aunque son nombres, significan tiempo y sin embargo no son verbos» (Caramuel 1654/2000: 85). Poco después, añade: «El verbo-sustantivo es la cópula propia de los nombres [...]. El verbo-adjetivo equivale a cópula y predicado. Como cuando decimos Pedro lee; pues el lee es lo mismo que está leyendo, es lector» (Caramuel 1654/2000: 86). Otro asunto distinto es de dónde procede esta propuesta, pues, como afirma Laborda Gil (1981): «en este punto hay feliz acuerdo entre Wilkins y Port-Royal» (Laborda Gil 1981: 154). Sobre la relación entre Caramuel y Port-Royal, en concreto en torno a esta propuesta de la naturaleza del verbo, véase Gutiérrez Cuadrado 1980: 64-65). Y para un estudio sobre el origen de la propuesta en general, véase Pamparacuatro Martín 2009). 
Así, si superficialmente una palabra como corre en Juan corre tiene la apariencia de verbo, en realidad los maestros de Port Royal reconocen en ella dos unidades distintas amalgamadas: el verbo, que no es otra cosa que la propia afirmación de verdad, y la cualidad de «ser corredor», que es el atributo. La labor del lingüista torna así, no en describir la superficialidad de las lenguas, sino en descubrir su verdadera estructura profunda (oculta) y explicar el paso de dicha estructura a la superficie morfo-fonológica.

The deep structure that expresses the meaning is common to all languages, so it is claimed, being a simple reflection of the forms of thought. The transformational rules that convert deep to surface structures may differ from language to language (Chomsky 1966: 35).

Esta propuesta de que las lenguas difieren solo superficialmente no está en la actualidad exenta de controversia. Por el contrario, parece haber en los últimos tiempos un resurgir importante de la vieja tesis relativista, conocida como Hipótesis de Sapir-Whorf, según la cual la lengua antecede y condiciona el pensamiento. En este sentido, la definición de verbo de los gramáticos de Port-Royal enlaza bien con una de las discusiones teóricas más actuales. Si no aceptamos que la diferencia entre las lenguas es superficial, dicha definición carece de sentido alguno.

\section{Ni sujeto (persona), ni tiempo}

Aceptando que existe una estructura profunda de la que se derivan las superficiales, aceptar que la cópula es en Juan es corredor no tiene información de atributo y que esta información se incorpora en el verbo corre de Juan corre no presenta, creemos, problema alguno. Otro asunto distinto es que se considere que en es no hay información ni de tiempo ni de persona. En principio, podríamos decir que, al menos formalmente, la forma es tiene información de persona (tercera) y tiempo (presente). Por ello, cabe preguntarse en qué sentido están afirmando los maestros de Port-Royal que en la cópula no existe tal información.

Comenzando por el principio, parece desprenderse de la afirmación de los maestros de Port Royal que la tercera persona es la «no persona». Según Hernández Alonso (1975: 127-130), quien se apoya en Benveniste (1966) y Alarcos (1970), hay varias razones para aceptar esto. En primer 
lugar, la naturaleza deíctica de la información de persona parece perderse en la tercera, pues si la primera se relaciona con el hablante y la segunda con el oyente, la tercera se vincula negativamente con no ser hablante ni oyente. Esto es, no tiene una vinculación deíctica concreta. Esto está relacionado, en segundo lugar, con el hecho de que en no pocas lenguas la tercera persona se relacione con el oyente en los contextos formales, para marcar cortesía. La propuesta es que, al tratarse de una forma no-personal, se refuerza la idea de alejamiento y por ende de cortesía. Por último, hay que tener en cuenta el hecho de que es propio de la tercera persona ser la forma para la impersonalidad. De ahí que se considere la no-persona o la forma impersonal. ${ }^{5}$

En resumen, pues, podemos considerar que lo que los autores mantienen es que en la cópula no hay información de persona, puesto que lo que conocemos como 'tercera persona' en realidad no es sino 'ausencia de información de persona'. Esto es muy interesante porque nos presenta un análisis binario de una información habitualmente considerada como terciaria. No hay que hablar, pues, de un sistema con tres posibilidades (primera, segunda y tercera), sino de un sistema binario, en el que el verbo puede contar con información de persona (+) o no (-). En el caso de que cuente con ella, la elección es entre primera y segunda. En el caso de que no, se marca con la habitualmente denominada tercera.

Por otra parte, de la misma manera que la tercera persona se considera "la no-persona», el presente se ve como «el no-tiempo». Una explicación de esto podría ser la siguiente:

Se ha dicho, con razón, que el presente es el no tiempo, o el elemento no marcado de la oposición temporal. Es decir, solo cuando se acota, se limita, la duración del presente aparecen el pasado y el futuro. De ahí que el presente pueda tener un valor general o persistente en frases como «El perro es el mejor amigo del hombre» en donde no existe más noción temporal que el presente (Ariza Viguera 2005: 6).

A partir de las palabras de Ariza, podemos considerar que con el tiempo presente puede pasar algo similar como con la tercera persona. Como

5 Por otra parte, desde el punto de vista formal, interlingüísticamente es habitual que se marquen la primera y la segunda persona en el verbo y no se marque la tercera. En lenguas como el inglés sucede justo al revés, dado que la única que se marca es esta última. En cualquier caso, es habitual que la tercera persona se comporte diferencialmente. 
recuerda Omar (2010: 132), «los enfoques lingüísticos tradicionales y estructuralistas caracterizan el tiempo como deíctico». Así, se puede proponer que esta naturaleza deíctica de la información de tiempo marca un límite temporal anterior (para el pasado) o posterior (para el futuro), mientras que no existe tal límite en el tiempo presente. De este modo, el presente es aquello que no se ha demostrado que sea ni pasado ni futuro y, por ende, puede ser considerado la marca de ausencia de tiempo explícito. En segundo lugar, desde el punto de vista formal, interlingüísticamente es habitual que se marquen pasados y futuros con una marca concreta y que no se marque presente. Por último, es propio del presente ser la forma para las verdades atemporales. De ahí que se considere el no-tiempo o la marca de atemporalidad.

De un modo paralelo al caso anterior, en el ámbito de las lenguas romances de nuevo aquí tenemos la posibilidad de pasar de un sistema terciario (presente-pasado y futuro) a un sistema binario, en el que la primera decisión es si se está marcando límite temporal (+) o no (-). En el primer caso, la decisión está entre el pasado y el futuro. En el segundo, aparece lo que conocemos como presente. Si abrimos un poco el elenco de lenguas revisadas, y buscamos un comportamiento más universal, el rasgo ligado a tiempo podría ser el de $+/$ - pasado (Omar 2010: 132). Sea como fuere, el presente sería un ítem no marcado.

En resumen, la definición de verbo en las obras de Port-Royal parte de la idea de que aparecer en presente y en tercera persona no supone presentar información ni de tiempo ni de sujeto, puesto que son precisamente marcas de no-tiempo y no-persona, respectivamente. Así, al pasar a presentar información de sujeto (en primera o segunda persona) o información temporal (en pasado o en futuro), ocurre lo mismo que cuando se amalgama al verbo su atributo: que hemos pasado de la estructura profunda, a la estructura superficial. Y si bien la estructura superficial admite n-elementos, la profunda es eminentemente binaria en naturaleza.

\section{Los límites de la semántica y la pragmática}

A diferencia de lo que ocurre con el tiempo y la persona, Arnauld y Lancelot sí consideran que la cópula est presenta información de modo (indicativo) y voz (activa). De hecho, es en virtud de esta información que 
el verbo significa la afirmación. El modo indicativo se ha concebido desde la Antigüedad como «el modo 'recto' sin matices modales» (Jiménez Juliá 1989: 176), frente al resto, que expresa elementos adicionales:

J'ai dit que le principal usage du verbe était de signifier l'affirmation, parce que nous ferons voir plus bas que l'on s'en sert encoré pour signifier d'autres mouvements de notre âme, comme ceux de désirer, de prier, de commander, etc.; mais ce n'est qu'en changeant d'inflexion et de mode: et ainsi nous ne considérons le verbe, dans tout ce chapitre, que selon sa principale signification, qui est celle qu'il a à l'indicatif (Arnauld y Lancelot 1660/1968: 176).

Esta aparentemente inocente definición de verbo está, de este modo, estableciendo los límites entre lo que siglos más tarde se conocerá como semántica oracional (terreno de las condiciones de verdad) y pragmática (ámbito de los denominados "Actos de Habla»). La idea de fondo podría ser que sin verbo no hay proposición, con sus condiciones de verdad y su compromiso de realidad. Por el contrario, el resto de información que aportan otros modos y voces queda fuera de la semántica oracional, pasando al terreno de la pragmática.

Ahora bien, si esto es así, y no estamos extrayendo conclusiones precipitadas, podemos dar un paso más y considerar que el hecho de que las referencias al tiempo y al sujeto (a la persona) queden fuera de la definición de verbo se pueden entender del mismo modo: esto es, que la referencia al tiempo y a la persona no se incluyen en la definición de verbo porque no pertenecen al terreno de la semántica (gramática), sino al de la pragmática. Enunciado desde perspectivas actuales como la Teoría de la Relevancia de Sperber y Wilson, podríamos decir que tiempo y persona pertenecen al ámbito de las explicaturas, esto es, el tipo de información que ha de enriquecerse con información sobre el mundo referencial. Tanto es así que, tal y como explica Omar (2010), en ocasiones el valor de las marcas temporales en contexto deja de ser estrictamente temporal para pasar a ser, por ejemplo, modal.

Que las explicaturas queden fuera de los límites de la semántica oracional parece, no obstante, a algunos, incompatible con el hecho de que su enriquecimiento sea el único modo de llegar a que la proposición tenga un valor en condiciones de verdad (Antonio Fábregas, comunicación personal). El problema residiría en que la base de la semántica oracional y del razonamiento estaría basada en un enriquecimiento pragmático, lo que ralentiza- 
ría innecesariamente el proceso de interpretación. No obstante, el problema desaparece si uno considera que a la semántica oracional y al razonamiento no le interesa la verdad del mundo, en realidad. Dicho de otro modo, se puede mantener en suspenso si la proposición es verdadera o falsa y actuar como si fuera verdadera a todos los efectos, dado que se puede aceptar que toda proposición, salvo las contradicciones, tienen al menos un mundo posible en la que su valor es 1 . Pero aun podríamos ir más lejos y considerar que las diversas formas de enriquecimiento posterior de las explicaturas parten de la premisa de que la proposición es verdadera en el mundo real, de modo tal que, en el caso de que sea incompatible dicha veracidad con una determinada interpretación, se cambia esta última.

De este modo, podemos considerar que existe un modo de salvar la contradicción aparente de que el valor de verdad final surja del enriquecimiento pragmático y que el valor de verdad de las oraciones sea la base de la semántica oracional, al tiempo que se mantiene que la pragmática enriquece a la semántica. Para la semántica, todas las oraciones son verdaderas, porque existe un mundo en el que son verdaderas. Que sean o no verdaderas en el nuestro es otro asunto. A todos los efectos actuaremos como si fuera verdadero porque así lo dice el emisor (con su compromiso de verdad). Él es el aval. Y lo hace porque utiliza un verbo. Superado este problema teórico, las explicaturas pueden quedar fuera del valor de verdad de las proposiciones, fuera de la base gramatical, tal y como parecen indicar los autores de Port-Royal.

\section{Predicación, categorías gramaticales y Aktionsarten}

Un último asunto al que queremos referirnos en estas páginas es al tipo de relación que se establece entre predicación-categoría y Aktionsarten. Si uno reflexiona acerca de la propuesta que sobre el verbo dan los maestros franceses, podría resumirla al modo de las reglas transformacionales típicas de la primera gramática generativa como: «si tiene usted un sujeto y un verbo (sea este un estado como conocer, una actividad como correr, un logro como enfermar o una realización como asesinar), en realidad esta estructura superficial proviene de una estructura profunda en la que usted tiene un sujeto, una cópula y un atributo (adjetivo y estado)». Así, Juan conoce la verdad es en realidad Juan es conocedor de la verdad, Juan corre es Juan es 
corredor, Juan enfermó es Juan está enfermo y Juan asesinó a Pedro es Juan es el asesino de Pedro. Dicho de otro modo, lo que indica su propuesta es que consideran que en el ámbito de la predicación, el aspecto léxico más básico es el de estado (hasta el punto de que todo evento se puede expresar como tal) y la categoría gramatical más simple es la de adjetivo, lo que no deja de ser acorde con las propuestas más actuales sobre predicación (véase, por ejemplo, Moreno Cabrera 2003; Baker 2003).

\section{Conclusiones}

Analizada brevemente la definición de verbo en las obras de PortRoyal, podemos tratar de contestar a la pregunta que nos hacíamos al principio de esta contribución: ¿Hasta qué punto la definición de verbo de los maestros franceses nos ayuda a entender problemas actuales de la ciencia lingüística? Creemos haber mostrado que su definición de verbo encierra una toma de partido en varias de las polémicas de la lingüística actual: frente al relativismo, apoya la existencia de una GU, en la que imperan las estructuras de naturaleza binaria, en la que el proceso de enriquecimiento de explicaturas queda fuera y en la que la estructura predicativa básica se organiza en torno a un predicado estativo y categorialmente adjetivo. Asuntos todos estos que todavía hoy, en pleno siglo xxI, continuamos discutiendo.

\section{Referencias}

Alarcos, E. (1970): Estudios de gramática funcional del español, Madrid.

Ariza Viguera, M. (2005): El indicativo, Biblioteca de Recursos Electrónicos de Humanidades E-ExceLence, Madrid, Liceus.

ARnAuld y LANCELOT (1660): Grammaire générale et raisonnée [citado por la edición facsímil de Bailly (1968): Grammaire générale et raisonnée de Port Royal, Ginebra, Slatkine Reprints].

Arnauld y Nicole (1662): La lógica o el arte de pensar, Madrid, Alfaguara, 1987. Baker, M. C. (2003): Lexical Categories.Verbs, Nouns, and Adjectives, Cambridge, Cambridge University Press.

Benveniste, E. (1966): Problèmes de linguistique générale, París.

Caramuel, J. De (1594/2000): Gramática audaz, Pamplona, Ediciones de la Universidad de Navarra. 
Сномкку, N. (1966): Cartesian Linguistics. A chapter in the history of Rationalist thought, Nueva York y Londres, Harper \& Row.

Donzé, R. (1970): La gramática general y razonada de Port-Royal. Contribución a la historia de las ideas gramaticales en Francia, Buenos Aires, Editorial Universitaria de Buenos Aires.

Gutiérrez Cuadrado, J. (1980): «Juan Caramuel y su teorema fundamental», Llull, 3: 39-107.

Hernández Alonso, C. (1975): «Las categorías de persona y número en el verbo español», Revista Española de Lingüistica, 5.1:121-137.

JimÉNEZ Juliá, T. (1989): «Modalidad, modo verbal y modus clausal en español», Verba: Anuario Galego de Filoloxia, 16: 175-214.

LABORDA GIL, X. (1981): Racionalismo y empirismo en la lingüística del siglo XVII: John Wilkins y Port-Royal, tesis doctoral, Universidad de Barcelona.

Lliteras, M. (1992): «Benito de San Pedro frente a la tradición nebrisense», en Bulletin Hispanique, 94.2: 505-527.

Moreno Cabrera, J. C. (2003): Semántica y gramática. Sucesos, papeles semánticos y relaciones sintácticas, Madrid, Antonio Machado Libros.

Omar Romero, D. (2010): «El tiempo verbal en la interpretación de enunciados", Pragmalingüistica, 18: 130-144.

Pamparacuatro Martín, J. (2009): «Aspectos cartesianos de la teoría del lenguaje de Port-Royal», Éndoxa. Series Filosóficas, 23: 101-138. 


\title{
PARTE III
}

\author{
LA EVOLUCIÓN \\ DE LA LINGÜÍSTICA APLICADA: \\ COMPARACIÓN, ENSEÑANZA \\ Y APRENDIZAJE DE LENGUAS
}





\section{LISTAS DE LENGUAS EN EL SIGLO XVIII. IDEOLOGÍA Y TAXONOMÍA EN LOS VOCABULARIOS POLÍGLOTOS DE PALLAS Y HERVÁS (1787)}

Juan Carlos Moreno Cabrera (Universidad Autónoma de Madrid)

\section{La cultura de las listas de lenguas: taxonomía e ideología}

La elaboración y propuesta de listas es uno de los elementos constantes de la cultura tanto literaria como científica. En la tradición occidental se hallan en la Biblia (en las genealogías, por ejemplo) y también en Homero. Este asunto ha sido tratado recientemente por Umberto Eco en un interesante libro (Eco 2009). No todas las listas son iguales, ni persiguen los mismos propósitos. Eco distingue dos tipos fundamentales de listas: la práctica y la poética. La primera tiene una utilidad determinada (por ejemplo, la lista de la compra o el catálogo de una biblioteca) y la segunda tiene una naturaleza estética, religiosa o relativa a alguna elaboración cultural concreta. Para Eco, las listas prácticas, entre las que se encuentran los dos vocabularios políglotos que vamos a examinar en este trabajo, poseen tres características (Eco 2009: 113). En primer lugar, tienen una función referencial, es decir, se refieren a objetos que se pretenden nombrar, enumerar y clasificar. Es el aspecto clasificatorio de las listas. En segundo lugar, estas listas son finitas, dado que tienen un ámbito de aplicación determinado y, por tanto, pueden considerarse más o menos completas. La completitud es 
el segundo de los aspectos característicos de las listas prácticas. En tercer lugar, no son alterables, pues solo se pueden completar si no son exhaustivas, pero no modificar o alterar. Es el carácter inmutable y cerrado de estas listas.

En otro lugar de su libro, Eco (2009: 133-134) nos describe la retórica de la enumeración. Un aspecto importante de esa retórica es la secuencia y combinación de términos lingüísticos pertenecientes a la misma esfera conceptual. Esta característica es típica de los vocabularios políglotos, en los cuales, se acumula una gran cantidad de palabras de varios idiomas que están en una misma esfera conceptual. Una figura retórica que cae en este ámbito es la congerie, que es una secuencia de palabras o frases que significan todas lo mismo y en la que se reproduce el mismo pensamiento bajo diversos aspectos. Los vocabularios políglotos entran de lleno dentro de esta figura retórica, aunque en el ámbito descriptivo y taxonómico, no poético.

En los vocabularios políglotos que vamos a examinar interactúan dos listas: una lista de palabras y una lista de lenguas. La lista de palabras genera una nueva lista de palabras para cada lengua de la lista de lenguas. Cada una de esas nuevas listas es equivalente, respecto los significados de las palabras, a los de la lista de palabras generatriz, que se toma como base. Por consiguiente, existe una lista de palabras que genera nuevas listas de palabras en función de una lista de lenguas. En los dos vocabularios que vamos a examinar brevemente podemos comprobar que las columnas están dominadas por la palabra de la lista generatriz y las filas por las lenguas en las que se encuentra una palabra equivalente a la palabra de esa lista generadora. Es importante tener en cuenta que hay una lengua que no aparece en la lista: se trata de aquella a la que pertenece la lista generatriz. Es la lengua que sirve de base de comparación, dado que las palabras cuyas correspondencias han de encontrarse en el resto de los idiomas pertenecen a esa lengua que sirve de punto de partida. Ella, además, es la meta-lengua en la que se redacta la lista y las explicaciones de ella. Es evidente que, a partir de aquí, se produce una imposición etnocéntrica: han de encontrarse las palabras que traducen en los distintos idiomas las palabras de la lengua de partida y, de paso, también los conceptos de la sociedad que la usa. Para evitar el etnocentrismo o, por lo menos, para disimularlo, se recurre a la utilización de palabras que denotan conceptos que parecen comunes a todas las sociedades, tales como las partes del cuerpo humano o los acciden- 
tes geográficos y otros elementos del medio ambiente. Sin embargo, como vamos a comprobar, siempre se cuelan en estos vocabularios palabras que denotan conceptos claramente dependientes y definibles solo dentro de una cultura determinada, por lo que los aspectos ideológicos nunca están ausentes de estas listas. Es más, estas listas son necesariamente etnocéntricas, pues la lista generatriz de palabras es la de la lengua que se toma como punto de partida para la consideración de los vocablos de los demás idiomas. Esto se deriva de que la propia actividad enumerativa y acumulativa está determinada por una cultura y una ideología específicas, que son las que dan sentido a estas abultadas nóminas. Las listas acumulativas, en las que algunos han visto uno de los orígenes posibles de la escritura, surgen de un tipo de civilización urbana en la que se producen concentraciones importantes de personas, bienes y productos de todo tipo. Esta tendencia se vio claramente favorecida por el desarrollo de las fuerzas productivas típicas del mercantilismo y del capitalismo.

He aquí una indicación de las causas que explican cómo surgió la escritura en Mesopotamia:

The growth of civilization required yet another advance in technology. The complex society of a city-state requires administration, and administrations requires record keeping. Early attempts to meet this need included the working out of a numerical tally system and perhaps the use of tokens, which stood for farm animals, quantities of grain, trade goods, or other objects that needed to be recorded. But these advances were not enough to meet the culture's growing bureaucratic needs. The technology that emerged to meet those needs — writing — filled a prosaic but essential purpose: accounting (Gnanadesikan 2009: 13-14).

En el caso de las listas que comparamos en esta contribución, surge la necesidad de hacer un inventario de los pueblos y lenguas sometidos a un imperio colonial, tal como se afirma explícitamente en la breve introducción del vocabulario de Pallas.

\section{La lista científica del siglo XVIII}

Las dos listas de palabras que examinamos en este artículo están inscritas dentro de un importante cambio de mentalidad que se opera en las sociedades europeas a partir del Renacimiento y que una historiadora de la lingüística ha caracterizado de la siguiente manera: 
Roughly in the middle of the fifteenth century a far-reaching change took place. The western European attitude to the outer world was transformed. Interest shifted from the universal and transcendental to the particular, visible, material phenomena all around us (Law 2003: 213).

Este cambio de actitud ante el mundo ocasionado, entre otras razones, por los descubrimientos derivados del colonialismo, lleva a plantearse la necesidad de hacer inventarios y taxonomías. Quizás el ejemplo más paradigmático en el siglo xviII sea el del científico sueco Carlos Linneo (1707-1778) y su taxonomía de los seres vivos: una lista estructurada jerárquicamente. Su obra Systema naturae, sive regna tria naturae systematice proposita per secundum classes, ordines, genera, et species, cum characteribus, differentiis, synonymis, locis fue publicada originalmente en 1735 y su última edición de 1770, constaba de tres mil páginas. Es uno de los ejemplos más importantes e influyentes de lista taxonómica estructurada que sirvió de modelo a las clasificaciones de las lenguas, tal como se afirma en la siguiente cita:

Some scepticism towards the repeated claim about a concrete influence of the sciences on linguistic thought or methodology is justified, but there is one field in which the connections between linguistics and scientific (mainly biological) work are real. The explosion of new linguistic material inevitably called the attention of those interested in language to the problems of classification and here they found themselves confronted with the much wider range of discussions about taxonomic principles which had dominated the study of plants and animals for more than a century. The Linnean classification, which gained incredible fame starting with the first part of the eighteenth century, was based on a series of hierarchical categories [...] The young Rask proposed a categorization of languages into race, class, stock, branch, language and dialect which deliberately matched that of Linnaeus. [...] Pott (1856, 191) wished for a linguistic Linnaeus who would classify the languages of the world (Morpurgo Davies 1998: 91, negrita de la autora).

Esta nueva mentalidad científica surgida en el siglo Xvi supuso un enfoque empírico de la realidad natural que también se extendió a la cultural. De hecho, autores como Thomas Linacre (1460-1524), J. Dubois (1478-1555), Julio César Escalígero (1484-1555), C. Gesner (1516-1665) o H. F. d'Acquapendente (ca. 1533-1619) tenían formación científica pero hicieron contribuciones significativas al estudio de la lengua (Law 2003: 222-223). Entre ellos podemos situar precisamente a P. S. Pallas (17411811), el famoso naturalista y zoólogo que compiló el vocabulario que lleva su nombre. Ya Leibniz consideró que la comparación entre lenguas 
(collatio linguarum) es la manera más eficiente de arrojar luz sobre el origen de los pueblos. En sus Desiderata detallaba un plan para la recogida de datos y solicitaba una colección de traducciones del padrenuestro en las diferentes lenguas (Simone 1998: 188). Estas colecciones de la oración dominical empezaron a realizarse antes de la propuesta de Leibniz y fueron ampliándose gradualmente con el correr de los años. He aquí una pequeña lista de estas colecciones con indicación del número de lenguas a las que se traduce el padrenuestro (Law 2003: 218): 1555: C. Gesner (22); 1593: J. Megiser (40); 1680: A. Muller (90); 1715: J. Chamberlayne (150); 1787: Lorenzo Hervás y Panduro (300); 1806-1817: Adelung y Vater (500). Esta empresa no se ha visto interrumpida con el correr de los siglos. Hoy mismo, en la siguiente dirección de Internet: http://www.christusrex.org/ www1/pater/index.html, puede encontrarse esta oración en 1662 lenguas. Estas colecciones provienen de una iniciativa claramente etnocéntrica, según la cual la religión cristiana es la única religión verdadera, lo que lleva a la necesidad imperiosa de imponerla a todos los pueblos, que no pueden ser privados de este supuesto bien espiritual. Estamos ante los restos de una civilización medieval entroncada de forma radical en el poder espiritual y que constituye lo que Anderson (1983: 30-39) denomina comunidad religiosa.

\section{Dos vocabularios políglotos del siglo XVIII}

El zar Pedro I fundó en 1724 la Academia de Ciencias rusa (RAN), uno de cuyos primeros cometidos fue explorar etnográficamente las áreas marginales menos conocidas del imperio ruso. La misma línea de investigación fue impulsada por Catalina II, quien, en 1784, tomó la iniciativa para hacer un vocabulario polígloto proponiendo una lista de unas trescientas palabras que deseaba que se tradujeran a unas 200 lenguas. Los materiales obtenidos fueron dados en 1785 a P. S. Pallas y en 1787 apareció el primer tomo de la primera parte del Linguarum totius orbis vocabularia comparativa Augustissimae cura collecta. Sectionis primae. Linguas Europae et Asiae complexae, Petropoli: Typis Iohannis Caroli Schnoor (1787) que contenía una lista de unas 300 palabras en doscientas lenguas (Simone 1998: 188). No voy a tener en cuenta aquí el segundo tomo, publicado dos años después, ni tampoco los dos tomos más de que constó la edición am- 
pliada de 1790-1791 al cuidado de F. I. Jankovic de Mirievo, ya que solo la primera parte del primer tomo apareció en el mismo año que la compilación de Hervás y Panduro.

Exactamente del mismo año es el Vocabolario Poligloto (1787) de Lorenzo Hervás y Panduro. Mientras que el vocabulario polígloto de la reina Catalina tenía un fin cultural-político (se trataba de comprobar la diversidad lingüística del imperio ruso), el de Hervás tiene un carácter mucho más cultural-lingüístico. De hecho, Hervás no se sentía satisfecho con la mera recopilación de listas de palabras (Morpurgo Davies 1998: 38), tal como se puede apreciar en el vocabulario de Pallas. Para él una lengua se define por su vocabulario, sus características fonológicas y, sobre todo, por su artificio gramaticale, es decir, aquella parte de la lengua que no admite cambios fundamentales (Morpurgo Davies 1998: 39). La importancia del artificio gramatical en Hervás había sido puesta de manifiesto antes por Val Álvaro (1986: 1235ss.) y Breva Claramonte (1991: 770ss.).

La estructura formal de los vocabularios es la misma. Constan de: una serie de palabras de un vocabulario básico universal de la lengua de partida (el ruso en el caso de Pallas y el italiano, en el caso de Hervás); unas columnas que forman una clase de equivalencia de vocablos de $n$ lenguas con respecto a cada una de las palabras del vocabulario básico universal; y una agrupación en forma de partición de esa clase de equivalencia sobre la base de una afinidad lingüística de tipo genético; la partición anterior está basada en otra clase de equivalencia: la formada por las lenguas que pertenecen al mismo grupo.

Los términos que sirven de base en el vocabulario de Pallas en su primer tomo, que es el publicado en 1787, son ciento treinta. Aparecen en la lista de la figura 1 con su traducción latina.

Por su parte, el Vocabolario de Hervás consta de los siguientes sesenta y tres vocablos:

Acqua, anima, animale, anno, bianco, bocca, braccio, capelli, capo, casa, chiaro, cielo, ciglio, collo, corpo, coscia, cuore, demonio, dente, dio, dito, dolce, donna, faccia, fronte, fulmine, fuoco, gamba, giorno, giù, gorgia, labbro, lago, lingua, luna, madre, mano, mese, miele, naso, nero, notte, occhio, odoroso, oscuro, padre, pesce, petto, piede, pioggia, rosso, sasso, selva, sole, spalla, stella, strada, sù, terra, uccello, vento, ventre, uomo. 


\section{FIGURA 1}

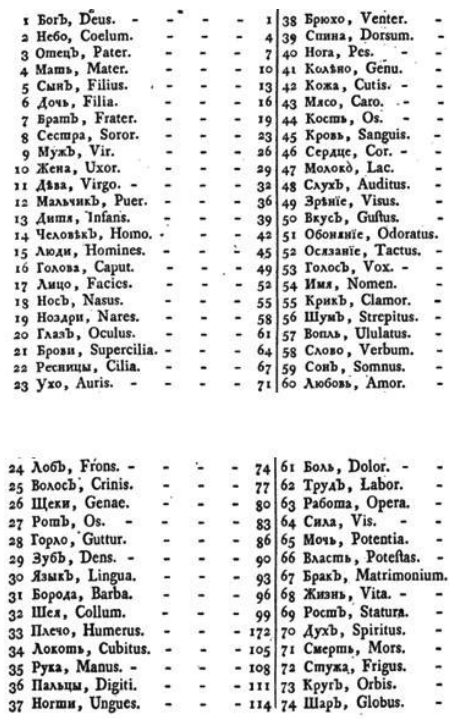

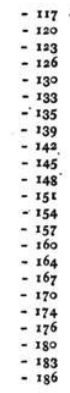

75 Conmue, Sol.
76 Micsub, Luna

77 3ntsaa, Stella.

78 Aysb, Radius.

79 Bimpb, Ventus.
80 Buxps, Turbo.

80 Buxps, Turbo.
81 Byps, Procella.

82 Aoxab, Pluvia.

83 Moxiix, Fulgur.

85 Caerb, Nix. -

86 Meab, Glacies.

82 \ень, Dies. -

83 Hors, Nox.

89 У

9t Xsmo, Aeltas.

92 Becha, Ver.

93 Ocens, Autumn

94 3asa, Hiems.
95 ToAb, Annus.

96 Bpews, Tempus.

97 3emax, Terra.
98 Bosa, Aqua.

99 Mope, Mare.

100 Ptra, Fluvius.

189 101 BОана, Unda.

- 193 103 Tutra, Argilla.

- 196204 Muess, Pulvis.

- 199105 r 106 rosb, Lutum.

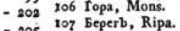

\begin{tabular}{l}
-205 \\
107 \\
\hline
\end{tabular}

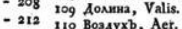

-212
-215
-210

- 218 112 Oroub, Ignis.

$\begin{array}{lll}-221 & 113 & \text { Жарь, Aeflus. } \\ -224 & 114 & \text { ГАубина, Profund } \\ -227 & 115\end{array}$

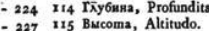

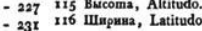

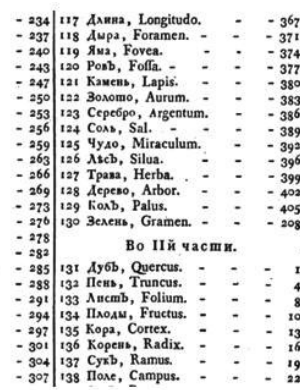

- 310|139 Ayrb, Pratum. - - 26

- 313 140 Knino, Frumentum. - - 29

- 316 141 Poxs, Secale.

\begin{tabular}{l|l}
-319 & 142 Osect, Avena. \\
-323 & 143 Buнorpasb, Uva.
\end{tabular}

\begin{tabular}{l|l}
-323 & 143 Buworpasb, U. \\
\hline-326 & 144 Pu6a, Piscis.
\end{tabular}

\begin{tabular}{l|l}
-326 & 144 Pw6a, Piscis. \\
-329 & 145 पepab, Vermis. \\
\hline
\end{tabular}

$33^{2} 146$ Myxa, Musca.

$3361473 \mathrm{ssps}$, Fera.

- 339148 Бuxb, Bos. -

\begin{tabular}{l|l}
-342 & 149 Kopona, Vacca. \\
-346 & 150 Баравb, Aries.
\end{tabular}

\begin{tabular}{l|l} 
- 346 & 150 Барakb, Aries. \\
- 349 & $15 t$ Porb, Cornu. \\
\hline
\end{tabular}

\begin{tabular}{r|ll}
-349 & $15 t$ Porb, Cornu. \\
-352 & 152 Korb, Eqvus.
\end{tabular}

- 355 153 Canss, Sus.

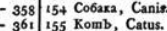

\begin{tabular}{l|l} 
- 361 & 155 Komb, Catus. \\
- 364 & 156 Mumb, Mus.
\end{tabular}

Como ya he señalado antes, se eligen términos básicos de carácter anatómico o ambiental que se consideran existentes en todas las comunidades humanas, tales como mano, pecho, pie, pierna, cabeza, frente, boca, lengua, dedo, uña, hombro, agua, animal, luna, pez, fuego, piedra, sol, dí, noche, cielo. Pero, junto a estos, hay términos claramente culturales como demonio (solo en Hervás), dios (en los dos vocabularios), matrimonio (en Pallas), amor (en Pallas) y milagro, prodigio o maravilla (en Pallas), correspondiente al vocablo ruso 125 (chúdo). Los términos de parentesco, que son comunes a ambos vocabularios, también son claramente culturales. Se observa, por consiguiente, que estas listas presentan aspectos claramente etnocéntricos. En el apéndice se reproducen las entradas para la palabra cielo en ambos vocabularios (figura 3 y figura 4). Como puede apreciarse, en el catálogo de Pallas, todas las lenguas están transcritas en la versión del alfabeto cirílico vigente en la época.

En el prólogo de su vocabulario, Pallas pasa revista a las familias de lenguas que va a incluir en las listas. En cuanto a las lenguas eslavas, establece una justificación para las hablas pequeño-rusas, que incluyen las hablas ucranianas y después justifica la inclusión del suzdalés, variedad en la que ve palabras griegas formadas según el modelo del ruso y palabras alemanas introducidas por la po- 
blación judía. A continuación, avisa de que el vascón ha sido puesto al lado de las lenguas celtas, pero no la variedad de España, sino la de Francia. Probablemente se refiera a lo que se conoce actualmente como gascón. No hay ninguna discusión lingüística detenida acerca de la filiación genética de las lenguas. Simplemente se presentan de forma sumaria y rápida algunos aspectos de la clasificación que se sigue. La agrupación de las doscientas lenguas elegidas es la siguiente:

Lenguas eslavas: eslavo, eslavo-húngaro, bohemio, serbio, véndico, sorabo, polabo, casubo, polaco, pequeño-ruso, suzdalés. Lenguas celtas: celta, bretón, irlandés, erse-escocés, galés, cornuallés. Lenguas helénicas: Griego, griego moderno. Lenguas romances: latín, italiano, napolitano, español, portugués, francés antiguo, francés moderno, valón. Lenguas germánicas: gótico, anglo-sajón, teutón, bajo-alemán, alemán, címbrico, danés, islandés, sueco, holandés, frisón. Lenguas bálticas: letón, lituano, livonio. Albanés, válaco (voloshski), húngaro. Avar, kubachín, lezguio. Lenguas fino-úgricas: Estonio, carelio, olonés, ziriano, permiako, mordovo, moksha, cheremiso, chuvacho, votiako, vogul ostiako. Lenguas iranias: persa, curdo, afgano, oseta. Lenguas semitas: hebreo, judío, caldeo, sirio árabe, maltés, asirio. Lenguas túrquicas: turco tártaro, kangato, teleuto, kirguiso, turcomano, yakuto. Lenguas del Cáucaso: Armenio, georgiano, esván, circasiano, abaza checheno, inguso, andi, kumiko. Lenguas samoyedas: tauguí, kamasa, karasi, mongol, kalmiko, tunguso, lamuto, chapoguir, yukaguiro, koriako, chukoto, kamchandal. Japonés, kurilés, chino, tangut. Lenguas indo-arias e iranias: romaní, indio, hindostaní, persa, cingalés. Lenguas drávidas: coreano, kanarés, malabar, tamil. Lenguas malayo-polinesias: boma, siamés, toakiano, malayo, javanés., cabuano, kapampangan, tagalo, neoguineano, neocaledonio, neozelandés, neoholandés, neocaledonio, lenguas de la isla de Tanna.

En contraste con el vocabulario de Pallas, la recopilación de Hervás contiene unos prolegómenos que son mucho más extensos que el vocabulario propiamente dicho. En ellos, se analizan detenidamente los criterios de la selección de las palabras y se estudia en detalle la afinidad lingüística de las familias consideradas. Estamos, pues, ante la obra de un lingüista, frente a la obra de Pallas, que era naturalista y no lingüista y que, razonablemente, se limita a recoger vocablos sin investigar las consecuencias lingüísticas de las afinidades o diferencias entre ellos. Merece la pena destacar que Hervás reconoce y detalla las afinidades entre las lenguas fino-úgricas incluyendo el húngaro y el finés, a diferencia del vocabulario de Pallas (Hervás 1787: 100-110) o entre las lenguas de la familia malayo-polinesia, incluyendo el malgache, también ausente en el vocabulario de Pallas (Hervás 1787: 37-44).

Las lenguas europeas y asiáticas incluidas en el vocabulario del Hervás son las ciento doce siguientes (excluimos las americanas porque no aparecen en el vocabulario de Pallas): 
Lenguas malayo polinesias: tahitiano, neoholandés, tagalo, visayo, malayo, capul, tidor, javanés, malgache. Chino, tonkinés, peguán, birmano. Lenguas indo-arias y drávidas: malabar, kanarés, maharati, hindostani, tail, telugu, sánscrito, guyarati. Kamchadal, koriako, kurilés, manchú. Lenguas del Cáucaso: Zan, georgiano, lezguio, armenio. Japonés, tibetano, mongol, kalmuko, persa, turco. Semiticas: hebreo, caldeo, siriaco, sarraceno, fenicio, árabe, egipcio, maltés. Griego clásico, vulgar, griego siciliano. Lenguas ugro-finesas: húngaro, lapón, finés. Eslavas: ruso, moscovita, polaco, bohemio, dálmata. Germánicas: gótico, anglosajón, teutón, címbrico, islandés, sueco, danés, inglés, flamenco, alemán, suizo-alemán. Celtas: céltico, bretón, galés, irlandés, erse. Bascuence, vizcaíno. Romances: latín, italiano, español, valenciano, catalán, portugués, francés, provenzal, rético (tres variedades), genovés, piamontés, tirolés, véneto, boloñés, lazio, etrusco, siciliano, válaco y romaní.

Si observamos el número de las lenguas eslavas y romances en los dos vocabularios podemos comprobar el sesgo localista de ambos. En el vocabulario de Pallas se enumeran once lenguas de la primera familia, frente a las cinco del vocabulario de Hervás. Exactamente lo contrario ocurre con la familia romance. Pallas incluye ocho lenguas romances en su vocabulario; Hervás, en contraposición, enumera veintiún idiomas romances. En los dos casos, se pueden encontrar más del doble de lenguas de una u otra familia en estos vocabularios.

En este breve artículo, he intentado situar de forma sucinta y concisa algunas de las propiedades de dos famosos vocabularios políglotos del siglo XVIII en su contexto cultural y lingüístico, señalando unos pocos aspectos notables ideológicos e historiográficos.

\section{Referencias}

Anderson, B. (1983): Comunidades imaginadas. Reflexiones sobre el origen y la difusión del nacionalismo, Méjico, Fondo de Cultura Económica.

Breva Claramonte, M. (1991): «Las ideas lingüísticas del siglo xviII en Lorenzo Hervás: la descripción de las lenguas del mundo", Anuario del Seminario de Filología Vasca "Julio de Urquijo", xxv-3: 769-781.

Eco, U. (2009): El vértigo de las listas, Barcelona, Lumen.

Gnanadesikan, A. E. (2009): The writing revolution, Oxford, Wiley-Blackwell. Hervás y Panduro, L. (1787): Idea dell'universo che contiene storia della vita dell'uomo, viaggio estatico al mondo planetario, e storia della terra, e delle lingue. Tomo XX. Vocabolario Poligloto, Cesena, en Lorenzo Hervás y Panduro. I. Vocabulario Poligloto (1787). II. Saggio Pratico delle Lingue (1787), estudio introductorio y edición facsímil de M. Breva-Claramonte y R. Sarmiento, Madrid, SGEL, 1990, 39-286. 
Law, W. (2003): The history of Linguistics in Europe. From Plato to 1600, Cambridge, Cambridge University Press.

Lepschy, G. (ed.) (1998): History of Linguistics. III. Renaissance and Early Modern Linguistics, Londres, Longman.

Morpurgo Davies, A. (1998): Nineteenth-Century Linguistics, Londres, Longman. Pallas, P. S. (1787): Linguarum totius orbis vocabularia comparativa. Augustissimae cura collecta. Sectionis primae. Linguas Europae et Asiae complexae, 2 vols., Petropoli, Schnoor.

Ротт, A. F. (1856): Die Ungleichheit menschlicher Rassen, hauptsächlich vom sprachwissenschaftlichen Standpunkte unter besonderer Berücksichtigung von des Grafen von Gobineau gleichnamigem Werke. Mit einem Überblicke über die Sprachverhältnisse der Völker. Ein ethnologischer Versuch, Meyer, Lemgo y Detmold.

Simone, R. (1998): «The Early Modern Period», en G. Lepschy (ed.) 1998: 149-236. Val Álvaro, J. F. (1986): «Sobre lengua e historia en el Catálogo de las lenguas de Lorenzo Hervás", en Estudios en Homenaje al doctor Antonio Beltrán Martínez, Zaragoza, Universidad de Zaragoza: 1231-1239.

\section{Apéndices}

\section{FIGURA 2}

Portada del vocabulario de Pallas
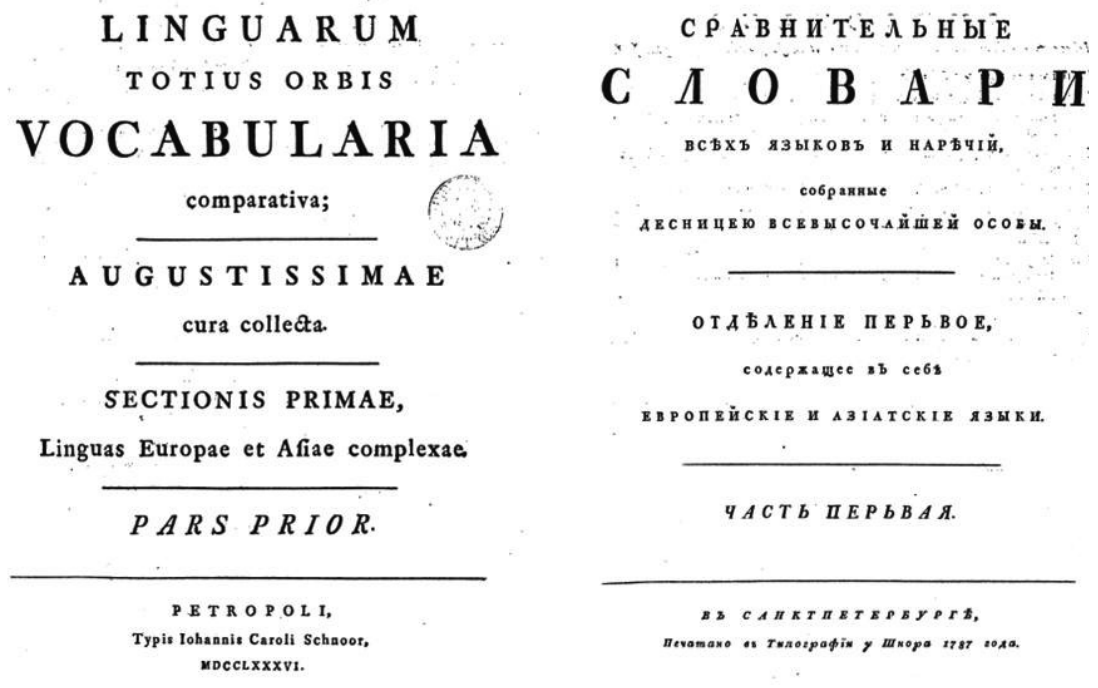

всьхъ языковъ И НАРвчІй,
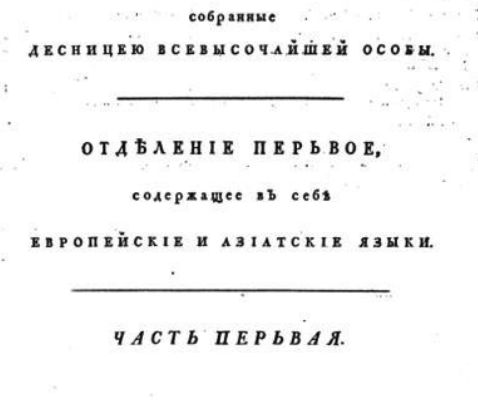

MDCCLXXXV1.

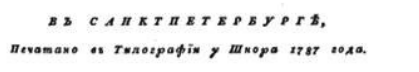




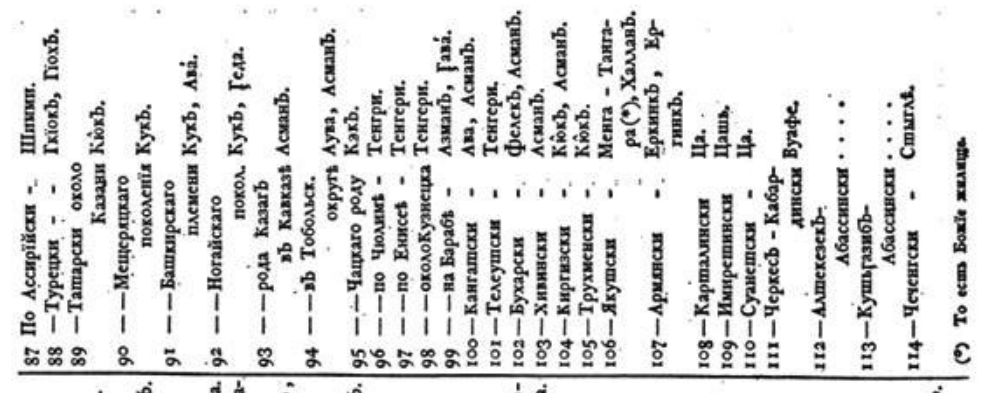

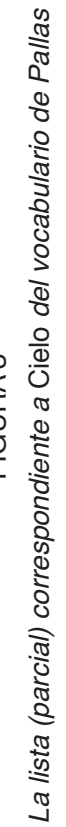
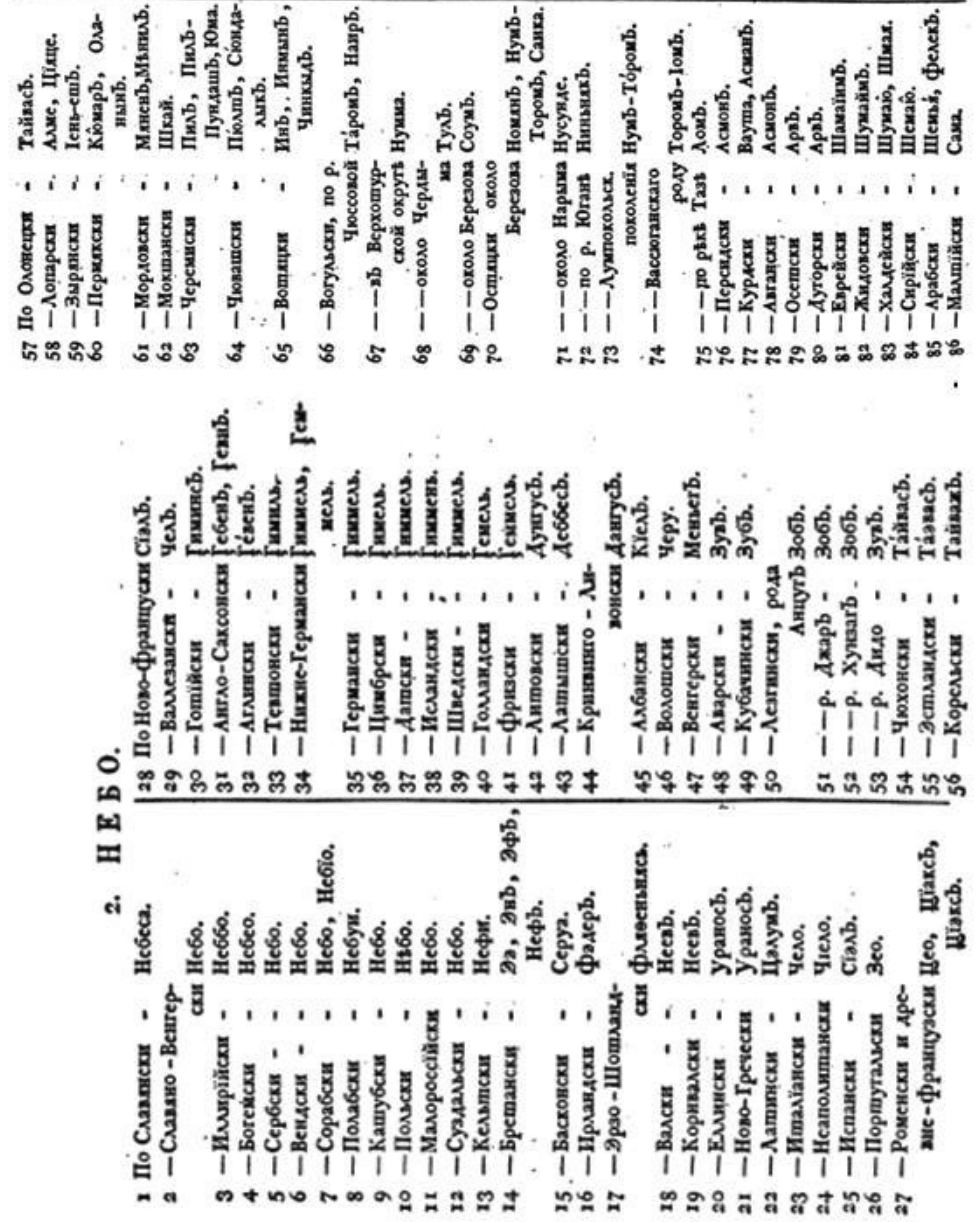


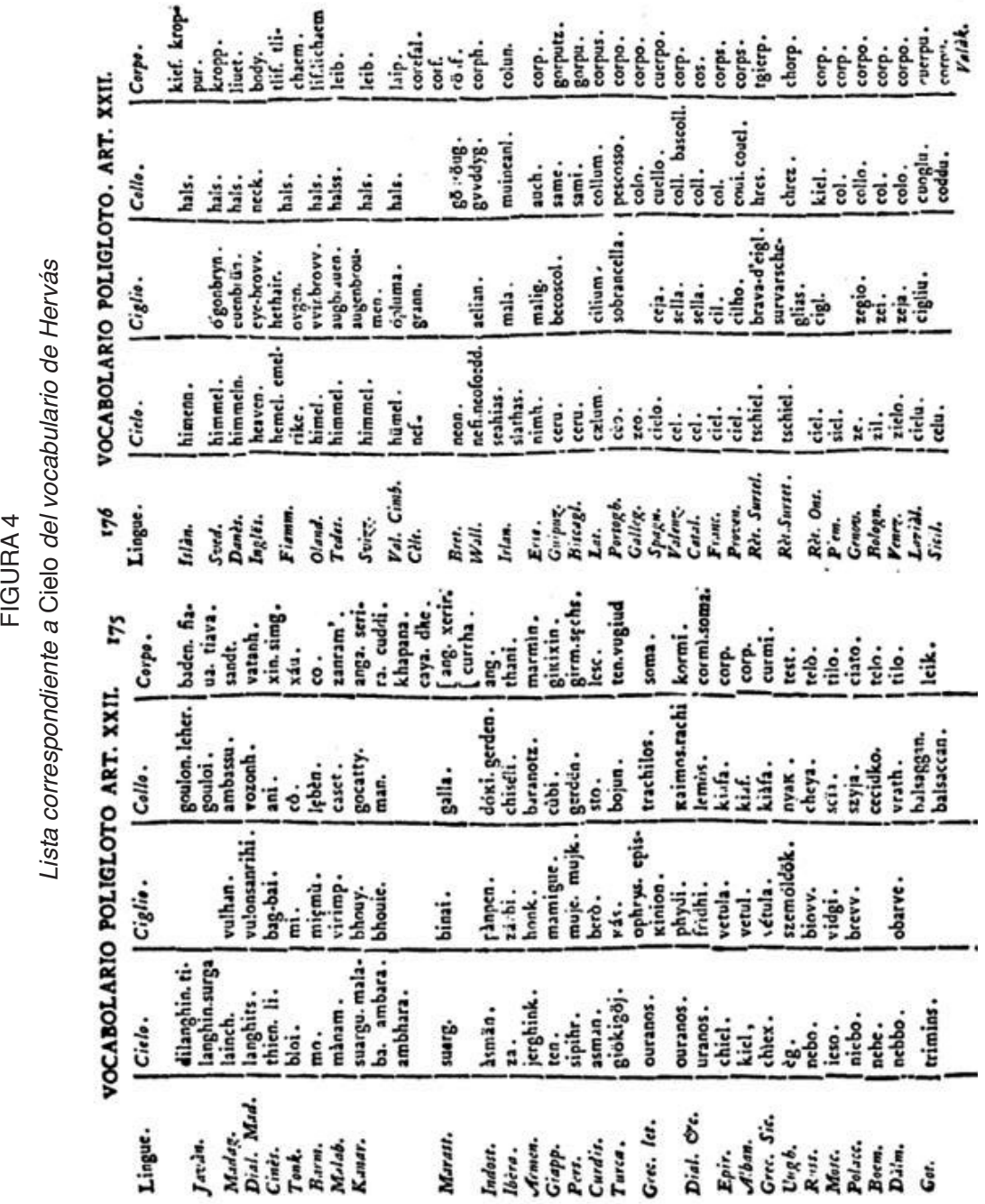




\title{
LA ACTUACIÓN LINGÜÍSTICA DE LOS MISIONEROS ESPAÑOLES «ARABISTAS» EN EL SIGLO XVI
}

\author{
Federico Corriente \\ (Universidad de Zaragoza)
}

La historia del arabismo lingüístico es un asunto que probablemente interese a la mayoría de los intelectuales occidentales tan superficialmente como, en general, la totalidad de disciplinas relacionadas con las que se considera culturas exóticas. ${ }^{1}$ Incluso dentro de los estudios árabes e islámicos, a los que algunos hemos dedicado la práctica totalidad de nuestros esfuerzos profesionales, son pocos los colegas que han estudiado a fondo la ciencia lingüística

1 Pues, al parecer, ya pocos creen en aquello de nibil humanum alienum mihi puto. De lo que ha sido prueba palmaria, en nuestro entorno más inmediato, la reciente sigilosa supresión del Instituto de Estudios Islámicos y del Oriente Próximo de Zaragoza, patrocinado y luego abandonado por las Cortes de Aragón, Consejo Superior de Investigaciones Científicas y Universidad de Zaragoza, a pesar de una brillantísima trayectoria de diez años, sin que ello mereciese una mención de la lamentable verdad, una mezcla de insidia y desidia, ni siquiera en la prensa local. En un terreno más exclusivamente académico, hemos tenido que aludir con cierta frecuencia al descuido de muchos romanistas en cuanto se relaciona con el importante papel de los ingredientes semíticos de sus disciplinas, la última vez en Corriente (2010), para señalar que en obra tan grandiosa y excelente no había habido atisbo de atención, ni consulta a otros especialistas, en las frecuentes entradas de étimos árabes, hebreos, etc. Es indudable que vivimos años aciagos para el conjunto de las humanidades, que programas como el llamado «plan Bolonia» tratan de reducir a mínima expresión, pero el campo de los estudios semíticos sufre muchísimo más esa tendencia que puede acabar con los rasgos más brillantes y universales de nuestra civilización. 
árabe, ${ }^{2}$ particularmente interesante e innovadora durante la Edad Media, con algunos autores como el genial Ibn Ğinnī, precursor de la gramática generativa, ${ }^{3}$ o el zaragozano Ibn Bārūn, iniciador de la lingüística semítica comparada, ${ }^{4} \mathrm{y}$ ello dentro del olímpico desinterés que suelen sentir los efímeros dominadores hacia los dominados, peligrosa actitud que Occidente ha adoptado hace siglos y que no sabemos cómo cambiar por otra más realista y positiva.

Pero en esta gozosa ocasión del homenaje al Prof. Val no pretendemos ni podemos profundizar en cuestiones de tal enjundia, a las que se han dedicado con afán, más que éxito, investigadores más comprometidos en macroanálisis socio-culturales, sino que las circunstancias nos aconsejan circunscribirnos a un asunto, por una parte más cercano en el tiempo, el espacio e incluso la dedicación, ya que en él, por otra parte, hemos tenido que intervenir en alguna ocasión anterior. ${ }^{5}$ Nos referimos a las características de la labor desarrollada en el siglo Xvi por algunos misioneros españoles entre moriscos, impulsados por su celo evangélico, o por el interés de sus obispos, en un peculiar marco histórico, a intentar la conversión al catolicismo de la población musulmana que había venido a quedar sometida al poder cristiano tras la Reconquista, particularmente de los reinos de Valencia y Granada.

Siguiendo un modelo que se remonta inmediatamente a precedentes medievales, ${ }^{6} \mathrm{y}$ en el fondo a una lógica intemporal, la predicación encami-

2 Con honrosas aunque escasas excepciones, como Carter (1981) y, en nuestro país, Ferrando (2001).

3 A ello aludimos en Corriente (1976: esp. p. 68, n. 1), al comentar su explicación de las formas reconstruidas y advertir de que tales formas originales no habían tenido a menudo nunca existencia real con las palabras: «What Ibn Jinnī had in mind was a generative transformational phonology, not a historical phonetics with room for a succession of actual forms in usage».

4 A la que dedicó un trabajo de alta divulgación nuestro colega de la Universidad de Granada, Martínez Delgado (2006), obra editada por el Instituto de Estudios Islámicos y del Oriente Próximo dentro de las varias e interesantes publicaciones de esta institución, que no han servido para ganarle el respeto de sus patrocinadores, ni el reconocimiento a la conveniencia de que siguiera existiendo.

5 Particularmente, al editar los materiales de P. de Alcalá (Corriente 1988) y al recensionar la edición de la Recopilación de algunos nombres arábigos de Diego de Guadix, por Elena Bajo y F. Maíllo, en la revista del mencionado Instituto de Estudios Islámicos y del Oriente Próximo, única en su campo de nuestro país (Corriente 2005). Anteriormente, habíamos dedicado algunas líneas al mismo asunto en Corriente (2008).

6 El más notorio el Vocabulista in arabico del siglo XIII, atribuido a Raimon Martí, conocido personaje del entorno dominicano de Mallorca, alumbrado por Raimon Lull, y 
nada a dicho objetivo se intentó, para hacerla más eficaz, que fuera en la lengua nativa de los catequizados, el árabe en su variedad andalusí, lo que, ante la inoperancia del don de lenguas que habría asistido a los apóstoles cristianos de los primeros tiempos, exigía la utilización de catequistas nativos y, para formarlos y controlarlos, la instrucción de misioneros supervisores en dicha lengua, así como la creación de unos instrumentos pedagógicos, fundamentalmente escritos, o sea, gramáticas, diccionarios y traducciones de los textos doctrinales. Ello supuso la implicación en tareas lingüísticas innovadoras de personas no habituadas a tales menesteres, más allá de la rudimentaria formación en latín y su gramática que proporcionaban los seminarios eclesiásticos a los futuros clérigos, con el limitado objetivo de que entendieran los textos litúrgicos fundamentales: el modo en que desempeñaron esta impuesta tarea no carece de interés científico ya que tuvo consecuencias científicas e históricas, cuya duración no se limitó a las escasas décadas que duró aquel intento de proselitismo, pronto abandonado como tarea imposible y sustituido por el decreto de expulsión de 1611, sino que se extendió por asimilación a las tareas similares de sus correligionarios en el continente americano, cuyas secuelas llegan prácticamente hasta nuestros días.

Tres fueron los misioneros «arabistas» del siglo xvi que dejaron obra escrita, el más notable por la extensión de su obra, que incluye arte, vocabulista y doctrina, el jerónimo Pedro de Alcalá (1505), ${ }^{7}$ a instancias del primer arzobispo de Granada, Hernando de Talavera, aún no cumplido el decenio desde la conquista de la ciudad; luego, el clérigo diocesano Bartolomé Dorador (1544), al servicio del obispo de Guadix, Martín de Ayala, autor el primero de la versión al árabe de una doctrina cristiana que el segundo no tuvo empacho en atribuirse, impulsando luego, ya arzobispo de

cuyo objetivo proselitista es claramente expuesto en su prólogo. Fue publicado por C. Schiaparelli en Florencia en 1871, estudiado por D. Griffin 1961, y de sus materiales hicimos un repertorio léxico en Corriente 1989. Su caso no es comparable al del llamado Glosario de Leiden, en realidad un diccionario de latín para mozárabes arabófonos toledanos, analizado por Van Koningsveld 1977, y cuyos materiales editamos y anotamos en Corriente 1991.

7 Los escasos ejemplares que sobreviven de las dos ediciones que se hicieron se han convertido hace mucho tiempo en tesoros de las bibliotecas que los poseen, por lo que esta obra es generalmente consultada en su edición por P. De Lagarde (1883) y su reimpresión de Osnabrück, O. Zeller, 1971. No es de fácil manejo por su pequeño tamaño la reproducción facsímil de la Hispanic Society of America, Nueva York, 1928. 
Valencia, otra similar, publicada en 1566 , sin que en este caso conozcamos siquiera el nombre del verdadero autor. ${ }^{8}$ En todo caso, las dos últimas obras son de escasa extensión y dudosa utilidad, incluso doctrinal, por esa misma brevedad e imperfecta hechura, mientras que la de Alcalá ha sido de siempre reconocida como notable, tanto por el cúmulo de materiales, de distinta calidad, que contiene, como por haber servido de puente entre la nueva escuela gramatical, preconizada por Nebrija y las gramáticas, diccionarios y textos de valor lingüístico de los misioneros del Nuevo Mundo, conexión estudiada con tanto ahínco por nuestro colega y amigo, O. Zwartjes. ${ }^{9}$

Al tratar esta cuestión, de la cual naturalmente nos interesan sobre todo las facetas puramente lingüísticas de esta actividad imprescindible, pero ajena a la naturaleza intrínseca del proselitismo religioso, conviene deslindar los predios de mayor rendimiento informativo científico, a saber:

1) Extracción social, étnica y cultural de las personas que emprenden esta labor.

2) Formación previa o especial que adquieren para ella.

3) Dedicación con que la realizan, a causa de determinadas motivaciones, y

4) Calidad de los resultados científicos obtenidos en su labor.

Probablemente este cuestionario sería rechazado en nuestros días como "políticamente incorrecto», si se intentara aplicar a alguna persona para juzgarle con vistas a un empleo o designación, pero las exigencias de la ciencia son diferentes de las de la política y sus modas, y el hecho es que ninguna de esas facetas es prescindible para obtener el análisis de datos que nos interesa.

8 Véase Díaz (1973: 29-30), con algunas referencias a las opiniones vertidas por determinados arabistas españoles acerca de estas obras. La obra de Dorador fue objeto de la tesis doctoral de M. a Paz Torres Palomo en la Universidad de Granada, quien comentó sus peculiaridades léxicas en las Actas del Congreso Internacional sobre interferencias lingüisticas arabo-romances y paralelos extra-íberos (pp. 201-9), celebrado en Madrid, 10-14/12/1990, publicadas en Zaragoza 1974, pero circunstancias personales no le han permitido la prometida publicación del ms. 1389 de la Biblioteca Nacional de Argel. En cuanto a la Doctrina Christiana de Valencia, nos ha llegado fundamentalmente en la edición facsímil de Roque Chabás, Valencia 1911.

9 Por ejemplo, en Zwartjes (2000). Las referencias al papel de puente de la obra de Alcalá se repiten en otras publicaciones suyas, como Zwartjes (1993, 1994). El mismo autor amplía su estudio y proporciona más bibliografía en Zwartjes (1988). 
Para empezar, la extracción social, étnica y cultural de aquellos misioneros no carecía de significado en la España de entonces, más bien lo tenía en una medida muy superior a lo que sería el caso en la actualidad. No es necesario recordar que las diferencias de clase, etnia y cultura en los siglos xVI y XVII, que particularmente nos interesan, eran enormes en nuestro país, entre nobles y plebeyos, cristianos viejos, nuevos, judíos y moriscos, cultos e incultos, y que ni siquiera las carreras universitaria, militar y eclesiástica, tradicionales atajos del ascenso social, permitían obviarlas, salvo en una reducida medida. Parece evidente que los jerarcas eclesiásticos que intentaron la cristianización mediante la predicación en lengua vernácula escogieron a los ejecutores en esta tarea por criterios de posible eficacia, y no de piedad, elocuencia sagrada ni otras virtudes, sino por su capacidad lingüística, probada o potencial. ${ }^{10}$ Ello dio lugar, cuando se empezó a analizar desde un ángulo lingüístico las obras que produjeron, ${ }^{11}$ a la temprana sospecha de que se tratara de conversos arabófonos, moriscos, como sospechaba Díaz ${ }^{12}$ o judíos, según su propuesta para el Glosario de Leiden, ${ }^{13}$ ya

10 No hay menciones particulares de atisbos de santidad o, al menos, ejemplaridad moral en ninguno de estos autores y, en el caso concreto de Diego de Guadix, su semblanza moral es bastante negativa (véase Corriente 2005: 102-3 y 112). Alcalá es, al menos, más humilde, pero suple a menudo su ignorancia con descaradas invenciones, descalificadoras en un hombre de ciencia, que han confundido a los investigadores hasta fechas recientes (véase Corriente 1988: I-IV y vi).

11 Como intentaron los arabistas Codera y Ribera de manera poco crítica, puesto que carecían de metodología apropiada y de conocimientos suficientes del árabe andalusí, cuya primera gramática completa, hay que recordar, fue nuestro A gramatical sketch of the Spanish-Arabic dialect bundle (Corriente 1977).

12 "En efecto, que un cristiano conociera en tan poco tiempo y con tanta perfección la lengua hablada de Granada... permite hacer elucubraciones sobre el posible origen del fraile jerónimo" (Díaz 1973: 68). Naturalmente, luego hemos sabido que los conocimientos de árabe granadino o literal de Alcalá estaban muy lejos de ser tan perfectos.

13 "Aunque el nombre del autor es desconocido, se podría sospechar con fundamento que era un judío, porque al final del códice y tras el "Glosario" se encuentran los nombres árabes y hebreos de las piedras preciosas, todo ello en caracteres árabes de la misma mano que el resto del libro, y también los nombres latinos y árabes de los planetas y de los signos del Zodiaco, con su traducción en hebreo en caracteres hebraicos, aunque la tinta de estos últimos es diferente y quizá sean debidos a otra mano» (Díaz 1973: 28). Bien es verdad que luego concede la posibilidad de suponer «que el autor del Glosario profesaba la religión cristiana y que era un mozárabe o bien un judío converso docto en ambas lenguas, árabe y latina y quizá también en hebreo». No es muy verosímil que un judío de la Península Ibérica transcribiese a la sazón el hebreo en grafía árabe, como sí hacían los caraítas de Oriente, no faltan voces hebreas transcritas en grafía árabe en algunas obras científicas de autores musulmanes, como los tratados botánicos (por ejemplo, el de Al'Idrīsī, que actualmente 
que no parecía creíble que personas totalmente ajenas a la arabofonía, como a la sazón eran prácticamente todos los cristianos viejos, por propia repugnancia a lo islámico, y por forzada prudencia ante el Santo Oficio, ${ }^{14}$ adquiriesen suficiente dominio del árabe en poco tiempo, por buenos que fueran los maestros nativos que los obispos les procuraban.

Es perfectamente comprensible que, en aquellas circunstancias, los estamentos marginados de la sociedad, musulmanes, judíos y conversos, tratasen de mejorar sus posiciones de cualquier manera: mediante alianzas matrimoniales con hidalgos venidos a menos, o gracias a carreras administrativas, militares o eclesiásticas, intentando ocultar sus orígenes y hacerse pasar por cristianos viejos, de todo lo cual hay sobrada evidencia y no nos concierne más ahora, y por medio de la posesión de cultura, estudios o habilidades especiales cotizadas, en el arte, la artesanía, ejercicio de la medicina, o de la interpretación de lenguas, uniendo a veces varias de estas capacidades. ${ }^{15}$ Esto vuelve a dirigir nuestra vista a la seria posibilidad de que algunos de estos misioneros «arabistas» fuesen conversos, del judaísmo o del islam, probablemente no sinceros, sino llevados por la marea de los acontecimientos a buscar un asidero vital tras el colapso de la sociedad en que ellos y sus inmediatos ascendientes, habían vivido. En el caso de Alca-

editamos), y es bien sabido que obras muy usadas se copiaban y pasaban de mano en mano y de comunidad en comunidad recibiendo interpolaciones, por lo que la autoría del Glosario de Leiden puede y parece ser mozárabe, con interpolaciones en el ejemplar conocido de un usuario judío. Algo parecido ocurre, por ejemplo, con el Lapidario de Alfonso X, cuya autoría es indudablemente árabe e islámica, pero cuyo ejemplar utilizado para la versión castellana que nos ha llegado era, sin duda, judeo-árabe, y que solo la grafía hebrea puede explicar buena parte de las deturpaciones de los nombres generalmente griegos de las piedras, como hemos estudiado recientemente en un artículo aún inédito, del que hay muestras en el arriba mencionado trabajo sobre el Diccionario de Kasten y Nitti.

14 Es bien sabido lo peligroso que podía ser cualquier conocimiento relativo al judaísmo o el islam, susceptible de ser interpretado como signo de herejía. Lo que nos recuerda que, en tiempos aún cercanos, durante nuestra última dictadura, el mero hecho de adquirir una gramática de ruso podía acarrear una visita de la policía, deseosa de conocer los motivos de tan subversiva afición lingüística.

15 Es bien conocido el caso del morisco Alonso del Castillo, médico, y en algún momento intérprete de Felipe II, estudiado por Cabanelas (1991), y de cuya sincera conversión al cristianismo hay que sospechar si, como parece seguro, fue uno de los autores de la falsificación de los famosos Libros Plúmbeos. En realidad, se trataba de personas llevadas por fatales circunstancias a un cripto-agnosticismo y que trataban de sobrevivir con los suyos plegándose al viento que soplaba, en este caso el servicio de las potencias cristianas y de la religión correspondiente. 
lá, no solo su ambiguo apellido, con una estructura frecuente entre los marranos, sino algunos extraños conocimientos, reflejados en su obra, de cultura hebrea, como los nombres que cita, sin venir a cuento, de las vocales dageš y qameș, de los "candilejos" (șubühiyyah = variedad de menorah o candelabro) y de la festividad de las "cabañuelas de Judíos» (nawwālah = sukkot), ${ }^{16}$ nos han sugerido que sea converso judío, entre los muchos que trataron de diluir su ascendencia mediante una carrera eclesiástica: en todo caso, no parece posible que pudiera ser morisco ya que, frente a lo que opinaba Díaz, su ignorancia de la lengua árabe es tan notoria, a pesar de indudables esfuerzos y la ayuda de nativos, obligados a ello por el arzobispo de Granada, que no parece posible pudiera nunca comunicarse en ella con los musulmanes granadinos, ni se concebiría que hubiera de inventar alguno de los disparates que le hemos localizado en su obra (Corriente 1988: ii-iv), aunque sin llegar ni de lejos al descaro de Diego de Guadix en su Recopilación, que hemos comentado en el artículo citado.

Tampoco puede haber ninguna duda de la ascendencia judía de este último, intérprete de la Inquisición, como hemos demostrado (Corriente 2005: 101-5), basándonos de nuevo en sus escasos conocimientos de árabe, que hacen imposible se trate de un morisco de Guadix, de donde él se daba por natural, en contraste con la notable corrección de los datos hebreos que facilita y, finalmente, por lo que se refiere a Bartolomé Dorador, es bien poco lo que de él sabemos, pero tampoco desentona su apellido con la descendencia judía prácticamente demostrada para Alcalá y Guadix. De donde podemos colegir que esta comunidad, tradicionalmente bien fami-

16 Bien es verdad que todas estas voces vienen en el Vocabulario español-latino de Nebrija (Madrid, Real Academia Española 1989), que le sirve de falsilla, y habría que preguntarse por qué están allí, pero no es lo revelador para nuestro propósito actual su presencia, sino las equivalencias que él les encuentra, particularmente en los dos últimos casos, ya que, admitiendo que en su escaso latín entendiese scenophagia o festum tabernaculorum, o le acercase a su realidad el castellano "cabañuelas» o que, aun sin ser judío ni converso, tuviese conocimiento de esta fiesta que traduce tan exactamente por el andalusí nawwála, ya no es posible ni que entendiese el rarísimo y algo deturpado eneamixos de Nebrija, "de nueve mechas», más griego (= ennea myxia) que latín, ni que conociera en tal caso el término $s u b h \bar{i}, \tan$ característico del judeo-árabe que solo figura, como tal, en el recientemente publicado diccionario de J. Blau (2006: 360), que recensionamos en Corriente (2007). Incidentalmente, sugiriendo una pronunciación doblemente errada, çubukía, típicamente andalusí y que excluye la transmisión libresca, aunque Dozy la corrigiera en su Supplément, gracias a sus conocimientos de árabe medieval. 
liarizada con el conocimiento del árabe, parece haber sido un filón importante, si no único, de misioneros «arabistas». Por otra parte, es bien sabido que la comunidad judía, tanto la de la Península Ibérica durante las Edades Media y Moderna, como en otras partes del mundo, era mucho más políglota que los cristianos y musulmanes de su entorno, por cuanto las frecuentes persecuciones que por doquier sufrieron les inclinaban a facilitar urgentes migraciones a zonas heteroglóticas más seguras: es bien sabido que muchos de los traductores del entorno de Alfonso X pertenecían a dicha comunidad, y que autores hebreos tan tardíos como el de la «Medicina castellana regia», del siglo xIV ${ }^{17}$ tuviesen el árabe como lengua vehicular de sus obras de medicina a pesar de ejercer en el entorno castellano, ya lejos geográfica y cronológicamente de las zonas de dominio islámico.

Pasando a la segunda cuestión que nos interesa, la eventual formación previa o especial que poseían o adquirían para ella estos misioneros, tendríamos que hacer un estudio exhaustivo de la profundidad de los estudios humanísticos en los seminarios diocesanos y regulares de la época en la Península Ibérica, algo que obviamente no podemos abordar aquí y ahora. Es previsible que la situación no fuese uniforme según los casos pero, para nuestro objetivo, sería suficiente investigar los casos particulares conocidos de los clérigos «arabistas» conocidos, e incluso, a causa de la escasa información que tenemos sobre Bartolomé Dorador y el anónimo traductor de la Doctrina Christiana de Valencia, nos podemos circunscribir a la competencia lingüística demostrada por los casos mejor documentados de Alcalá y Guadix. Del escaso talante moral y científico del primero creemos haber dicho lo suficiente en la citada recensión de la edición de su recopilación; en cuanto a Alcalá y a pesar de su indudable aprovechamiento de la doctrina lingüística de Nebrija, y de sus ocasionales citas latinas, hay que reconocer que sus conocimientos en este campo, como en los de lengua árabe, parecen haber sido poco profundos, como decíamos en la edición de sus materiales (p. ii): no es nada refinado su castellano, ni sólida su información gramatical, como demostró al confundir pronombres personales y relativos (p. 14 de la edición de Lagarde), o al pretender enunciar reglas, como la de la acentuación de patronímicos (p. 6) o la formación del segundo gerundio (p. 25), totalmente desmentidas por sus propios ejemplos, lo

17 Véase García Ballester y Vázquez de Benito (1990). 
que se junta al descaro con que pretende suplir su ignorancia, al fabricar imperativos pasivos y plurales imposibles, y su incapacidad de reconocer y evitar erratas, meramente gráficas, ${ }^{18}$ deslindar registros dialectales y clásicos, ${ }^{19} \mathrm{o}$ incluso a evitar alguna zancadilla tendida por sus auxiliares nativos que parecen haber querido burlarse de él en algún caso. ${ }^{20}$

La dedicación con que se entregaron estos misioneros a su labor parece haber sido intensa, con independencia de los motivos que los animaran, amor propio, deseo de no perder el aprecio de sus superiores y la situación privilegiada que disfrutaban mientras tanto, honradez y profesionalidad, etc. Volviendo al caso típico de Alcalá, no muy distinto en este aspecto del de Guadix, es indudable que dedican muchas horas de esfuerzo a la producción de sus obras, con independencia de que la metodología utilizada y su preparación previa fuesen las más adecuadas para llevarlas a buen puerto.

Ello nos lleva directamente al último de los cuatro epígrafes planteados, la calidad de los resultados científicos obtenidos en su labor. En este terreno, y en contraste con las críticas y reservas que hemos hecho en el caso de los anteriores, es de toda justicia reconocer que los misioneros «arabistas», y particularmente Alcalá, tuvieron varios aciertos notables, que serían precedentes metodológicos importantes, a saber:

a) Crear un sistema de transcripción latina de lenguas poseedoras de otra grafía, algo tanto más necesario por cuanto la árabe habitual, más bien una estenografía, deja a la reconstrucción del lector gran parte de la información fonológica. El sistema ideado por Alcalá,

18 Verbigracia su carquit 'pulpo', mera mala lectura del >qarnit < del Vocabulista in arabico, errata que ya detectara Simonet, producida por el parecido gráfico de las letras qäf y nün en el árabe occidental, sin que, por otra parte, reconozca nunca haber tenido a su disposición tal fuente.

19 De algún modo alcanzó el conocimiento de la diferencia de registros, de manera que sus diálogos doctrinales y guía de la confesión se ajustan bastante bien al granadino, mientras que las oraciones litúrgicas intentan acercase al árabe clásico, pero con notables oscilaciones en ambas direcciones, aunque parece haber utilizado algunas fuentes escritas, no solo el Vocabulista in arabico, sino también alguna fuente cristiana oriental para dichos casos.

20 Por ejemplo, no hay ninguna otra documentación de que el imperfectivo del verbo amár 'ordenar' fuese *yamír, sino siempre yamúr, por lo que resulta probable que dicha forma sea en realidad lo que significa 'dar pienso a una cabalgadura'. 
al parecer totalmente original y suyo, luego imitado en la Doctrina Christiana valenciana, es aún bastante imperfecto, pero constituye un avance cualitativamente importante sobre las transcripciones anteriores del árabe a la grafía latina, y fue el precedente de las transcripciones científicas del XIX y posteriores.

b) Reconocer el interés lingüístico de los registros bajos, no literarios ni clásicos de la lengua árabe, con lo que se puso los cimientos de la dialectología de esta lengua, bastantes décadas antes de que se escribiera la obra de Dombay, ${ }^{21}$ por no hablar de los dialectólogos del XIX y continuadores hasta hoy.

c) Utilizar la encuesta lingüística con hablantes nativos, bien es verdad que de una forma rudimentaria, alejada de los cuestionarios utilizados en el siglo $\mathrm{xx}$, pero en todo caso con una constancia notabilísima, que permitió a Alcalá concretamente dejarnos un diccionario del granadino que, con todas sus imperfecciones, ha sido fuente importantísima de la lexicología andalusí y del árabe occidental.

d) En el campo de la lingüística aplicada o teórica ya hemos avanzado que la preparación de estos misioneros era demasiado somera para esperar de ellos grandes contribuciones, puesto que incluso su conocimiento de la gramática latina o castellana en la forma preconizada por Nebrija era limitado. Sin embargo, hay que reconocer, por ejemplo, a Alcalá, su clarividencia de que toda lengua, incluso vulgar, tiene una gramática formada por reglas que pueden ser enunciadas, y no son corrupciones desordenadas de la lengua culta que las precede.

Los esfuerzos de Alcalá no cayeron en saco roto, aunque precisamente no fue en nuestro país donde más se los apreciara y utilizara, ya que el siguiente misionero arabista importante español, el franciscano Lerchundi, ${ }^{22}$ no se aprovecha del avance supuesto por los grafemas especiales de transcrip-

21 Grammatica linguae mauro-arabicae juxta vernaculi idiomatis usum: accésit vocasbularium latino-mauro-arabicum. Opera et studio Francisci de Dombay, Viena, 1800, que fue el siguiente eslabón en el estudio de la dialectología árabe.

22 En sus famosos Rudimentos del árabe vulgar que se habla en el Imperio de Marruecos (Madrid, 1872) que en sucesivas ediciones sirvió durante décadas a cuantos españoles se interesaron por aprender el árabe marroquí. 
ción inventados por Alcalá, cuya obra conoce perfectamente, y vuelve a un sistema medieval de diagramas y ambigüedades, que no serían superados entre nuestros arabistas universitarios hasta la adopción, ya por Asín, entrado el siglo xx, de una extrańa adaptación del sistema centro-europeo, que sigue en vigor sorprendente y retrógradamente entre la mayoría de los arabistas españoles ya del siglo xxi, a pesar de las advertencias que han recibido sobre la inoportunidad de aquella "nacionalización» de un sistema internacional. Como a menudo sucede en nuestro país con las agudezas e invenciones de sus hijos, al tiempo que la "Escuela» universitaria española despreciaba olímpicamente estas contribuciones a la dialectología, fueron algunos investigadores de allende nuestras fronteras, como el alemán C. Brockelmann en su monumental obra sobre las lenguas semíticas (Brockelmann 1800), o el gran conocedor del árabe occidental G. Colin, en su clásica entrada lingüística para el artículo Al-Ándalus de la Encyclopédie de l'Islam (Colin 1960) quienes sacaron mayor fruto de los datos de Alcalá, aun sin poder someterlos a escrutinio profundo, que habría de esperar aún bastantes décadas.

\section{Referencias}

Blau, J. (2006): Milon lètẹssțim Sarbiyim yěhudim mi-yĕmē ha-bènayim (A Dictionary of Mediaeval Judaeo-Arabic texts), Jerusalén, The Israel Academy of Sciences and Humanities.

Brockelmann, C. (1908-13): Grundriss der vergleichenden Grammatik der semitischen Sprachen, Leipzig.

Cabanelas, D. (1991): El morisco granadino Alonso del Castillo, Granada, Patronato de la Alhambra y el Generalife.

CARTER, M. (1981): Arab linguistics: an introductory classical text with translation and notes, Ámsterdam.

Colin, G. (1960): «L'arabe hispanique», Encyclopédie de l'Islam, Brill, 2 I: 516-519.

Corriente, F. (1976): «From Old Arabic to Classical Arabic through the preIslamic koiné: some notes on the native grammarians' sources, attitudes and goals», Journal of Semitic Studies, 21: 62-98.

- (1977): A gramatical sketch of the Spanish-Arabic dialect bundle, Madrid, Instituto Hispano-Árabe de Cultura.

- (1988): El léxico árabe andalusí de P. de Alcalá, Madrid.

- (2005): «Reseña a E. Bajo y F. Maíllo: Recopilación de algunos nombres arábigos de Diego de Guadix", Estudios de Dialectología Norteafricana y Andalusí, 9: 93-114. 
Corriente, F. (2007): «Notes on a basic work for the study of Middle Arabic: J. Blau's Milon lèteqsstim Sarbiyim yěhudim mi-yèmè ha-bènayim (A Dictionary of Mediaeval Judaeo-Arabic texts)», Collectanea Christiana Orientalia, 4: 311-355.

- (2008): «Missionary's Middle Arabic: the case of Late Andalusi», en Moyen Arabe et variétés mixtes de l'arabe à travers l'histoire. Actes du Premier Colloque International (Louvain-la-Neuve, 10-14/4/2004), Louvain-la-Neuve, Université Catholique, Institut Orientaliste: 87-98.

- (2010): «Apostillas etimológicas a las voces orientales del Diccionario de la prosa castellana de Alfonso X de Kasten y Nitti», Revista de Filología Española, 90.1: 47-106.

De Lagarde, P. (ed.) (1883): Petri Hispani de lingua arabica libri duo, Gotinga, A. Hoyer

DíAz, V. A. (1973): El dialecto árabe hispánico y el "Kitâb fì laḥn al-âmma» de Ibn Hišâm al-Lajmî, tesis doctorales de la Universidad de Granada 56, Universidad de Granada.

Ferrando, I. (2001): Introducción a la historia de la lengua árabe. Nuevas perspectivas, Zaragoza.

García Ballester, V. L. y M. C. Vázquez de Benito (1990): «Los médicos judíos castellanos del siglo XIV y el galenismo árabe: El Kitāb al-qaštälī almulūkī (libro de medicina castellana regia)», Asclepio, 1: 119-147.

Martínez Delgado, J. (2006): La semitística comparada en Alándalus. De los origenes a Ibn Brūn, Zaragoza, Instituto de Estudios Islámicos y del Oriente Próximo.

Zwartjes, O. (1988): «La estructura de la palabra según las primeras gramáticas de lenguas mesoamericanas y la tradición greco-latina», en Estudios de Lengua y Cultura Amerindias II, Valencia, Universidad de Valencia: 99-121.

- (1993): «El artículo en las gramáticas pioneras de Antonio de Nebrija y Pedro de Alcalá y las gramáticas de la tradición grecolatina», en Diálogos Hispánicos, 11, España: ¿Ruptura 1492?, Ámsterdam/Atlanta, Rodopi: 261-286.

- (1994): «Tradición e innovación en las gramáticas pioneras de A. De Nebrija y P. de Alcalá: La categoría del pronombre», en Actas del Congreso Internacional de Historiografía Lingüistica. Nebrija V Centenario 1492-1992, Murcia: 651-665.

- (2000): «Modo, tiempo y aspecto en las gramáticas de las lenguas mapuche, millcayac y guaraní de Luis de Valdivia y Antonio Ruiz de Montoya: La categoría de los 'tiempos mixtos'", en Las gramáticas misioneras de tradición hispánica (siglos XVI-XVII), Ámsterdam/Atlanta, Rodopi: 205-256. 


\title{
DOS LENGUAS Y UNA MENTE. HISTORIA DE LA INFLUENCIA INTERLINGÜÍSTICA EN LA ADQUISICIÓN DE SEGUNDAS LENGUAS*
}

\author{
Alberto Hijazo Gascón \\ (Universidad de Zaragoza)
}

\section{Introducción}

¿Qué ocurre en nuestra mente cuando nos comunicamos en una segunda lengua? ¿Por qué cuesta tanto librarnos de nuestra lengua materna cuando aprendemos una segunda? La adquisición de segundas lenguas es un fenómeno muy complejo en el que intervienen numerosos factores. Uno de ellos es el que intenta dar respuesta a estas preguntas. Se trata de la influencia que ejerce una lengua sobre otra cuando un hablante, que conoce las dos, se comunica en una de ellas. Este fenómeno ha recibido varios nombres a lo largo de la historia, como señala Odlin (2003): transferencia, interferencia lingüistica, papel de la lengua materna, influencia de la lengua nativa, mezcla de lenguas, etc. En este artículo, utilizaremos de manera intercambiable dos términos: transferencia (en inglés transfer) e influencia interlingüistica (en inglés crosslinguistic influence) porque son los más utilizados en la bibliografía especializada. La transferencia se puede definir de la siguiente manera:

* Este trabajo se ha llevado a cabo gracias a la financiación del proyecto MovEs del Ministerio de Ciencia e Innovación (FFI2010-14903). 
The influence resulting from the similarities and differences between the target language and any other language that has been previously (and perhaps imperfectly) acquired. [La influencia que resulta de las similitudes y diferencias entre la lengua meta y cualquier otra lengua que ha sido adquirida previamente (y quizás de forma imperfecta) (Odlin 1989: 27, traducción nuestra)].

El término tradicional, interferencia, propuesto por Weinreich (1953), se ha abandonado por las connotaciones conductistas del término y por implicar una visión negativa del fenómeno. Kellerman y Sherwood Smith (1986) proponen el término influencia interlingüistica por ser un término neutral desde un punto de vista teórico y por ser adecuado para definir la gran variedad de maneras en las que el conocimiento de una lengua puede afectar el conocimiento y uso de otra lengua.

Todas las teorías de adquisición de segundas lenguas admiten que la transferencia es una cuestión importante. Este fenómeno debe entenderse como complementario de los procesos cognitivos generales y las variedades del aprendiz (Ellis 1994, Perdue 2000), es decir, otras cuestiones que podemos observar en los procesos de adquisición de una segunda lengua (L2), que no se deben a la lengua materna (L1). En esta contribución explicaremos brevemente la historia de los estudios sobre la influencia interlingüística y apuntaremos las direcciones de la investigación futura en esta línea.

\section{Tipos de influencia interlingüística}

El fenómeno de la transferencia es complejo y en numerosas ocasiones ha supuesto problemas el aproximarse a él desde una perspectiva simplista. Para dar una visión panorámica del fenómeno, presentamos los distintos tipos de influencia interlingüística atendiendo a varios factores.

La clasificación clásica de Odlin (1989) se basa en el nivel de la lengua en el que se produzca la transferencia. Esta está presente en todos los niveles. Por ejemplo, se da en la pragmática en cuestiones de cortesía en relación con el rostro de los interlocutores (Brown y Levinson 1987) en actos de habla como peticiones, disculpas y saludos. También en cuanto a los estilos conversacionales y narrativos se observa la influencia de la L1. En la semántica, señala el beneficio de reconocer los cognados (cognates), términos con parecido formal y de significado en la L1 y la L2. Un conocido 
caso de influencia interlingüística es el uso de los falsos amigos, que implican utilizar una palabra de la L2 que es similar en forma a la de la L1 pero cuyo significado no coincide. Piénsese por ejemplo en el italiano imbarazzata 'avergonzada' y el español embarazada. Sin embargo, en el plano de la semántica también pueden darse transferencias positivas favoreciendo la comprensión lectora, por ejemplo, de hablantes de L1 sueco al leer textos en inglés.

En cuanto a la morfosintaxis, se ha considerado que es el plano del lenguaje en el que menos se da la transferencia. Sin embargo, encontramos algunos casos de transferencia positiva. Por ejemplo el uso de artículos en una L2 cuando también están presentes en la L1. Además, se ha observado transferencia en otras cuestiones como la formación de oraciones relativas. Por último, en la fonética y fonología es donde más clara parece la existencia de transferencia y es más difícil su erradicación, piénsese por ejemplo en la /e/ protética de los hispanohablantes ante /s-/ inicial en L2 inglés. En numerosas ocasiones estas transferencias negativas acaban en casos de fosilización.

La complejidad del fenómeno de la influencia interlingüística ha supuesto que se hagan muchas clasificaciones de los tipos de transferencia, abordados desde distintas perspectivas. Una de las cuestiones que se han tratado recientemente, los tipos de transferencia en función de la direccionalidad, puede resultar de especial interés. Jarvis y Pavlenko (2008) utilizan tres términos: transferencia hacia delante (forward transfer), transferencia reversa (reverse transfer) y transferencia lateral (lateral transfer). Tradicionalmente se ha observado la transferencia que se produce desde la L1 de los hablantes a su L2, pero también podemos observar el sentido contrario, es decir, cómo influye la L2 en una L1. Por ejemplo, si una hablante espańola viviendo en Italia dice que va a meterse la chaqueta (por mettersi la giacca) en lugar de ponérsela.

Por otra parte, también podemos encontrarnos con influencias entre una L2 y una L3, lo que se entiende como transferencia lateral. ${ }^{1}$ Por ejemplo un hablante de inglés como L3 que tiene como L1 el euskera, pero también habla español puede realizar transferencias desde su L2. También

1 Véanse los trabajos recogidos en Cenoz, Hufesein y Jessner (2001) para una visión más pormenorizada de este tipo de transferencia. 
puede ser entre una L3 y una L1, etc. Es importante resaltar que no siempre diferenciamos la L2 y la L3 en función del orden en el que se adquieren estas lenguas. Por ejemplo un hablante de L1 español puede estudiar inglés en el colegio y después ir a vivir a Francia. Posiblemente la L2 de esa persona sea el francés, ya que vive en un entorno de inmersión, mientras que el inglés lo tendrá relegado a un tercer lugar. En definitiva, el orden de adquisición es uno solo de los factores relevantes como el nivel de competencia en esa lengua, si el uso de esa lengua es frecuente y/o reciente y si es similar a su lengua materna. De hecho, los últimos estudios, entre ellos los de transferencia reversa (Bylund y Jarvis 2009), parecen demostrar que la L1 no debe entenderse como inalterable sino que su estatus es variable (Gullberg 2011).

Finalmente, queremos llamar la atención sobre un tipo especial de influencia interlingüística, que destacaremos por su relevancia en los últimos estudios del fenómeno. Se trata de la transferencia conceptual. Según el criterio de nivel cognitivo, Jarvis y Pavlenko (2008) señalan la diferencia entre transferencia lingüística y transferencia conceptual. Sobre todo, consideran que es importante diferenciar entre transferencia semántica y transferencia conceptual. La primera es aquella que trata con fenómenos relacionados con el sistema lingüístico, en concreto con el significado. Por otra parte, la transferencia conceptual se define como la influencia que una lengua puede ejercer sobre otra en los diferentes niveles cognitivos. En este sentido está muy presente la teoría neorrelativista de Slobin (1996), por la que tendríamos tres niveles cognitivos: (a) pensar, (b) pensar para hablar y (c) hablar. El pensar para hablar (Thinking for Speaking) consiste en la actividad mental que entra en funcionamiento en el proceso comunicativo. Con la investigación que se ha realizado hasta el momento, parece ser que la influencia interlingüística se produce en los dos últimos niveles: el hablar y el pensar para hablar, pero no en el pensar, desechando la idea relativista de que la lengua que hablamos condicione nuestro pensamiento.

Estos autores señalan que en casos como He bit himself in the language 'Se mordió en el lenguaje' en lugar de He bit himself in the tongue 'Se mordió en la lengua' por parte de un hablante de finés, la transferencia producida es semántica, porque en finés solo hay una palabra polisémica para ambos significados (kieli 'lengua, lenguaje'). La transferencia se produce en el nivel semántico y no en el nivel conceptual. Sin embargo, Jarvis y 
Pavlenko (2008: 120) explican que cuando un aprendiz de ruso con L1 inglés pide una chashka 'copa' en relación con un vaso de plástico, la transferencia es semántica pero también conceptual, porque no conoce los contenidos de la categoría conceptual. En ruso este tipo de contenedor de líquido pertenece a la categoría de los vasos (stakany), mientras que en inglés los contenedores de plástico y papel para bebidas son miembros periféricos de la categoría de las copas. Así, aunque ambas lenguas tengan equivalentes en la traducción, las categorías conceptuales mediadas por estas palabras son diferentes en cuanto a los miembros periféricos. Jarvis y Pavlenko (2008) entienden que la adquisición de una L2 también incluye reestructurar las categorías conceptuales existentes en la L1. A este tipo de influencia interlingüística la llaman transferencia conceptual, porque se origina con las representaciones conceptuales, aunque también implique representaciones semánticas (es decir, uniones entre conceptos y palabras). Hay que destacar que no solo se da transferencia conceptual en los elementos periféricos de las categorías, también en elementos centrales. Por ejemplo, los autores señalan casos como la diferencia entre ser y estar en español como L2 por parte de hablantes anglófonos.

Una vez aclarado en qué consiste la influencia interlingüística y los distintos tipos que podemos encontrar según varios factores, explicaremos brevemente en el próximo apartado la historia de los estudios de transferencia.

\section{Un breve recorrido por los estudios sobre influencia interlingüística}

El interés por la relación entre la lengua materna y la segunda lengua ha estado presente desde el mismo momento en el que los hombres comenzaron a hablar otras lenguas que no eran la suya. Son interesantes en este sentido los estudios sobre la transferencia en el Mundo Antiguo (Adams, Janse y Swain 2002). De hecho, el término bárbaro en griego se refería al extranjero, más concretamente a aquel que hablaba "mal griego", es decir, que hablaba griego como segunda lengua con influencia de la primera. La visión tradicional acerca de las transferencias de la L1 a la L2 fue relacionarlas con la estupidez, la torpeza en el aprendizaje de lenguas o la lentitud mental. No fue hasta los años cuarenta y cincuenta con los estudios de Fries (1945), Weinreich (1953), Haugen (1953) y Lado (1957) 
cuando se pasó a considerar la transferencia como una característica inevitable e intrínseca del aprendizaje de lenguas, fundamental para comprender numerosos fenómenos socio y psicolingüísticos. Odlin (2003) señala que el primer lingüista en tratar de forma autónoma el fenómeno fue Weinreich en Languages in Contact (1953). Este autor estudia fundamentalmente los casos de interferencia, es decir, los casos en los que la lengua materna supone dificultades en el discurso de la lengua segunda. Actualmente, como ya indicamos, se ha abandonado este término, por considerar que tiene connotaciones negativas y que obvia los casos en los que la influencia de la lengua materna es positiva y facilita el aprendizaje. Hoy en día se prefiere el término de transferencia por ser más neutro.

Jarvis y Pavlenko (2008) repasan la historia de la disciplina de investigación en torno a la transferencia y señalan cuatro grandes fases. En la primera fase se reconoce el fenómeno y se estudia su papel como factor en procesos como el de adquisición de segundas lenguas. Estaríamos en los albores de un estudio sistemático de la transferencia, desde las observaciones anotadas ya en la filología del siglo XIX y pasando por las teorías conductistas de adquisición del lenguaje, hasta la consolidación del generativismo. Como señala Ellis (1994), el término de interferencia fue una noción crucial en los años cincuenta y sesenta con el Análisis de Errores. Los lingüistas del momento identificaban diferencia con dificultad, una idea que todavía sigue presente en el imaginario colectivo, aunque no es siempre acertada. De hecho, la hipótesis del Análisis Contrastivo (Contrastive Analysis Hypothesis) se basaba en la asunción de Lado (1957: 2) de que los elementos similares a la lengua nativa son los fáciles para el aprendiz y los diferentes son los difíciles. Los académicos de los sesenta siguieron esta línea de investigación, buscando diferencias entre las lenguas europeas que llevasen a la producción de errores.

En una segunda fase, a partir de los ańos setenta del siglo xx se investiga el fenómeno como un ámbito de estudio en sí, con sus propias variables y explicaciones. A diferencia de la etapa anterior, la identificación entre diferencia y dificultad que proponía la hipótesis del análisis contrastivo fue decayendo. La razón fundamental fue la constatación de que muchos errores no los causaba la transferencia y que los errores que predecía el análisis contrastivo no necesariamente se cumplían. Además, el ascenso del generativismo también supuso un cambio en el interés en los estudios de adquisi- 
ción de segundas lenguas, que pusieron el énfasis en los procesos generales de adquisición y consideraron que la influencia de la lengua materna era menor. Odlin (2003) señala que los investigadores interesados en la Gramática Universal no focalizan su atención en la transferencia aunque reconocen su importancia. Este autor señala que la influencia interlingüística no supone ni un apoyo ni un rechazo a la cuestión del acceso a la Gramática Universal, más bien se mantiene al margen. Por lo tanto, pese a la importancia teórica del generativismo que abarcó todas las áreas de la lingüística, se siguió trabajando en el ámbito de la transferencia y la influencia interlingüística, al entenderse que se trataban cuestiones diferentes. Eso sí, se reconoció que la hipótesis del Análisis Contrastivo era demasiado simplista y restrictiva. También se empezó a adoptar otra perspectiva, al trabajar también con el concepto de transferencia positiva y observar las ventajas que en ocasiones proporciona el conocimiento de la lengua materna.

Durante los ańos ochenta y noventa comienza una tercera fase en la que se desarrollan teorías específicas que buscan explicar los fenómenos en relación con las restricciones sociales, situacionales y mentales. Se desarrollan modelos teóricos que explican cómo, cuándo y por qué se da la transferencia y qué tipos se dan. Se plantean ya hipótesis específicas y comprobables acerca de la influencia interlingüística y se intentan comprobar. Una de las propuestas más interesantes es la de la transferencia a alguna parte (transfer to somewhere) de Andersen (1983). Este principio tiene dos componentes: (a) cualquier elemento de la L1 debe ser compatible con los principios naturales de adquisición para transferirse a la L2 y (b) el input en la L2 debe facilitar la generalización de un elemento de la L1. Si se cumplen estas condiciones, es fácil que se dé la transferencia. Uno de los ejemplos clásicos que ilustran el principio de transferencia a alguna parte es el trabajo de Zobl (1980). Los hablantes de inglés L1 producen un sobreuso del orden SVO en francés L2, incluso en casos en los que el objeto antecede al verbo, como en las construcciones con pronombres clíticos. Así, es frecuente que los hablantes anglófonos hagan una transferencia de su L1:

(1)
a. L1: I see him
yo ver.PRS él.AC
'Lo veo'
b. L2: *Je vois le
yo ver.PRs.1sG él.AC
'Lo veo' 
Sin embargo, los hablantes francófonos no realizan esta transferencia en su L2 inglés, ya que no encuentran casos de SOV en el input que reciben en inglés. Por lo que nunca realizan una transferencia del tipo de $(2 \mathrm{~b})$ :
a. L1: Je le vois
yo él.AC ver.PRS. ISG
'Lo veo'
b. L2: *I him see
yo él.AC ver.PRS
'Lo veo'

En todo caso, el fenómeno de la influencia interlingüística va más allá y parece claro que además del principio formulado por Andersen (1983) es posible realizar transferencias según otros factores, por ejemplo, la similitud tipológica de las lenguas en cuestión. Ringbom (1987) en sus estudios sobre el inglés de fineses bilingües de L1 finés (L2 sueco) o de L1 sueco (L2 finés), señala la importancia de la transferencia positiva, ya que pese a que los dos grupos de hablantes recibían la misma instrucción en inglés como L2, los hablantes de sueco tenían ventaja al menos en las primeras etapas del proceso de adquisición. Esto supone una influencia interlingüística clara, favorecida por el parecido tipológico entre las dos lenguas germánicas frente al finés que pertenece a una familia lingüística diferente a la indoeuropea. Además, se observó que los hablantes de finés tenían en su output en inglés L2 más influencia del sueco que de su propia lengua materna, mientras que los hablantes de sueco no utilizaban transferencias del finés al inglés. Sus resultados muestran que no siempre la lengua materna determina la influencia y que el papel de la distancia entre lenguas que perciben los hablantes (lo que Kellerman en 1977 denomina psicotipología) juega un papel determinante en los elementos que pueden transferirse o no. Además dejaba claro que era necesario ampliar el principio de transferencia a alguna parte, ya que se demostraba que cualquier lengua conocida por el hablante (la domine o no) puede servir para iniciar una transferencia.

Con el fin de complementar el trabajo de Andersen (1983), Kellerman (1995) propone el principio de transferencia a ninguna parte (transfer to nowhere):

This principle states that there can be transfer which is not licensed by similarity to the L2, and where the way the L2 works may very largely go unheeded. [Este principio postula que puede haber transferencia que no se deba a las si- 
militudes con la L2, y en la que se ignore totalmente el funcionamiento de esta segunda lengua (Kellerman 1995: 137, traducción nuestra)].

En este caso, las diferencias entre las lenguas sí que provocan dificultades. Eso sí, este principio no se refiere tanto a diferencias en la forma gramatical sino en el modo en el que los hablantes conceptualizan la experiencia. Kellerman (1995) se basa en la teoría del pensar para hablar de Slobin $(1991,1996)$, para ilustrar cómo funciona el principio. Slobin (1993) considera que las categorías del pensar para hablar son muy resistentes a cambiar al adquirir una segunda lengua. Esto no significa que todas las diferencias lingüísticas constituyan una gran dificultad en la adquisición de una segunda lengua. Como señala Slobin, algunas categorías de la segunda lengua pueden adquirirse sin problemas, aunque no estén presentes en la lengua materna, cuando son fácilmente perceptibles. Por ejemplo, en el caso del plural. En japonés el plural no se marca en los sustantivos, pero a sus hablantes no les causa problemas marcar el plural con una -s en su L2 inglés. En cambio, otras distinciones pueden resultar más complejas, como en el caso de la expresión de la contigüidad de un objeto a una superficie en holandés. Como señala Kellerman (1995), para aprendices anglófonos de holandés como L2 es difícil prestar atención a esta noción, tal y como hacen los holandeses al utilizar los verbos de posición leggen 'poner en posición horizontal' y zetten 'poner en posición vertical'. ${ }^{2}$ Este principio complementa al de la transferencia a alguna parte, ya que explica que los aprendices pueden no ser capaces de sacar provecho de correspondencias interlingüísticas porque el pensar para hablar podría estar por encima de la consciencia individual. Dicho de otro modo, el modo específico de cada lengua de conceptualizar la experiencia llevaría a la transferencia a ninguna parte.

Finalmente, Jarvis y Pavlenko (2008) señalan que en el siglo xxi estamos avanzando hacia las explicaciones acerca de cómo el fenómeno tiene lugar en el cerebro. Se encuentran pruebas de conexiones neurológicas interlingüísticas en la memoria a largo plazo de una persona y cómo esas conexiones se forman, se cambian y se mantienen. También pruebas de cómo las lenguas se activan en el cerebro y como el conocimiento de una

2 Para un estudio pormenorizado en torno a esta cuestión en la adquisición de holandés como L2 teniendo en cuenta también el componente gestual, véase Gullberg (2009). 
lengua puede activarse e interferir con su uso de otra lengua. En este sentido, las técnicas psico y neurolingüísticas como el eye-tracking ('seguimiento de los ojos') o la electroencefalografía, ya aplicadas en otros campos lingüísticos como el estudio de afasias o el procesamiento del lenguaje, pueden ser de gran utilidad. Además permiten observar la influencia interlingüística no solo en tareas de producción, sino también de comprensión. El movimiento de los ojos puede explorar la relación entre el lenguaje y otras habilidades cognitivas, como la atención y la memoria. Se ha utilizado esta técnica en cuestiones como los aspectos perceptuales de la identificación de palabras o la comprensión de metáforas (Richardson, Dale y Spivey 2007). La electroencefalografía por su parte mide la actividad electrofisiológica del córtex en respuesta a estímulos lingüísticos. Puede ser de especial interés para observar cómo los aprendices procesan su segunda lengua en relación con los nativos y para observar si la L1 tiene un efecto en el procesamiento de la segunda lengua.

\section{Conclusiones}

Nos queda todavía mucho para saber cómo las lenguas interactúan en la mente de un individuo. Como señala Gullberg (2011) uno de los retos de la disciplina será ver en qué dominios la transferencia conceptual tiende a ocurrir y qué tipos de transferencia son posibles en cada fase y cuáles no. Además, el estudio del componente gestual, que por falta de espacio no hemos tratado aquí con detenimiento, añade detalles a nuestro entendimiento de las conceptualizaciones de los hablantes de segundas lenguas. Por ejemplo, parece que estamos más dispuestos a abandonar una categoría de la L1 que a añadir nuevas categorías de la L2 o a ampliar/dividir categorías de la L1 para alinearlas con la L2 (Gullberg 2011: 161). Otra cuestión fundamental es si una vez que se desarrolla una representación nueva en la L2 esta coexiste con la previa en la L1, en relación también con los estudios de bilingüismo.

Con nuevas técnicas y con un desarrollo considerable en los estudios en esta área, la investigación futura, incluyendo distintas lenguas, con distintos tipos de transferencia y en distintas direcciones, puede ayudar mucho al desarrollo de este campo. No solo eso sino que, como hemos visto, los avances en los estudios de transferencia suelen beneficiar a otras disci- 
plinas lingüísticas como la sociolingüística, el bilingüismo, la psicolingüística y la neurolingüística. En definitiva, se trata de observar qué ocurre cuando dos lenguas conviven en una sola mente. Una pregunta difícil que, por el momento, solo nos ofrece un reto investigador como respuesta.

\section{Referencias}

Adams, J. N., M. Jansen y S. Swain (eds.) (2002): Bilingualism in Ancient Society. Language Contact and the Written World, Oxford, Oxford University Press.

Andersen, R. (1983): «Transfer to somewhere», en A. Valdman y A. Highfield (eds.), Theoretical orientations in creole studies, Nueva York, Academic Press: 273-295.

ByLund, E. y S. JARVIS (2009): «L2 effects on L1 event conceptualization», Bilingualism: Language and Cognition, 12: 305-322.

Brown, P. y S. Levinson (1987): Politeness: Some Universals in Language Usage, Cambridge, Cambridge University Press.

Cenoz, J., B. Hufesein y U. Jessner (2001): Cross-linguistic influence in third language acquisition: Psycholinguistic perspectives, Clevedon, Multilingual Matters.

ElLIs, R. (1994): The study of second language acquisition, Oxford, Oxford University Press.

Fries, C. (1945): Teaching and learning English as a foreign language, Ann Arbor, University of Michigan Press.

Gullberg, M. (2009): «Reconstructing verb meaning in a second language: How English speakers of L2 Dutch talk and gesture about placement», Annual Review of Cognitive Linguistics, 7: 222-245.

- (2011): «Thinking, Speaking and Gesturing about Motion», en A. Pavlenko (ed.), Thinking and Speaking in Two Languages, Clevedon, Multilingual Matters: 143-169.

Haugen, E. (1953): The Norwegian language in America, Filadelfia, University of Pennsylvania Press.

Jarvis, S. y A. Pavlenko (2008): Crosslinguistic Influence in Language and Cognition, Nueva York y Londres, Routledge.

Kellerman, E. (1977): «Towards a characterization of the strategy of transfer in second language learning», Interlanguage Studies Bulletin, 2: 58-145.

- (1995): "Crosslinguistic influence: Transfer to nowhere?», Annual Review of Applied Linguistics, 15: 125-150.

- y M. Sherwood Smith (eds.) (1986): Crosslinguistic influence in second language acquisition, Oxford, Pergamon. 
Lado, R. (1957): Linguistics across cultures, Ann Arbor, University of Michigan Press.

OduIn, T. (1989): Language transfer: Cross-linguistic influence in language learning, Cambridge, Cambridge University Press.

- (2003): «Crosslinguistic influence», en C. Doughty y M. Long (eds.), The handbook of second language acquisition, Oxford, Blackwell, 436-486.

Perdue, C. (2000): «Organising principles of learner varieties», Studies in Second Language Acquisition, 22(3): 299-305.

Richardson, D., R. Dale y M. J. Spivey (2007): «Eye movements in language and cognition: A brief introduction», en González-Márquez, Coulson, Mittelberg y Spivey (eds.), Methods in Cognitive Linguistics, Ámsterdam y Filadelfia, John Benjamins.

Ringbom, H. (1987): The role of the first language in foreign language learning, Clevedon, Multilingual Matters.

SLOBIN, D. (1991): «Learning to think for speaking. Native language, cognition and rhetorical style», Pragmatics, 1: 7-29.

- (1993): «Adult language acquisition: A view from child language study», en C. Perdue (ed.), Adult language acquisition: Cross-linguistic perspectives, Cambridge, Cambridge University Press: 239-252.

- (1996): "From "thought and language" to "thinking for speaking"», en J. Gumperz y S. Levinson (eds.), Rethinking linguistic relativity, Cambridge, Cambridge University Press: 70-96.

Weinreich (1953): Languages in contact, La Haya, Mouton.

ZoвL, H. (1980): «The formal and developmental selectivity of L1 influence on L2 acquisition", Language Learning, 30: 43-57. 


\section{LAS ACTIVIDADES DE PRÁCTICA \\ GRAMATICAL EN LA ENSEÑANZA \\ DEL ESPAÑOL COMO LENGUA EXTRANJERA}

Enrique Aletá Alcubierre

(Universidad de Zaragoza)

\section{Introducción}

En este trabajo efectuaremos una presentación de las actividades destinadas a la práctica de la gramática dentro de cada una de las metodologías que suelen distinguirse en la enseñanza de lenguas extranjeras y, en concreto, en la enseñanza de ELE: Gramática y Traducción, Método Directo, Paradigma Estructural y Paradigma Comunicativo.

Las cuatro metodologías mencionadas presentan en común la ausencia de una reflexión para fijar pautas adecuadas para el diseño de los ejercicios de gramática. En efecto, cada uno de los modelos parte de un particular modo de concebir la gramática y su enseńanza-aprendizaje y elabora actividades para la práctica gramatical que resulten coherentes con esos presupuestos. Se busca, ante todo, la homogeneidad del modelo con sus actividades correspondientes y no es habitual que se reflexione sobre la forma más adecuada de presentar el input gramatical de manera que favorezca el proceso de adquisición por parte del alumno de lenguas extranjeras.

Será con el Modelo de Procesamiento del Input, elaborado a partir de la década de los noventa, cuando proliferen investigaciones centradas en el 
diseño de actividades gramaticales que desarrollan propuestas que no buscan crear una nueva metodología de enseńanza sino encontrar el tipo de ejercicio gramatical que resulte eficaz para el proceso de aprendizaje-adquisición de la gramática.

\section{Gramática y Traducción}

El concepto de lengua en el que se fundamenta este modelo es puramente intuitivo, sin base científica alguna. Se concibe la lengua como un conjunto de palabras, de reglas y de excepciones. El concepto de aprendizaje es consecuente con el concepto de gramática expuesto: aprender una lengua consiste en memorizar esas palabras, reglas y excepciones, explicadas en la lengua materna del estudiante. Por tanto, se considera que un alumno ha aprendido una segunda lengua cuando es capaz de expresar en esta lengua (es decir, de traducir) todo lo que puede decir en su lengua materna.

A partir de estos planteamientos, es esperable el tipo de actividades que se proponen para la ejercitación gramatical: se explican reglas gramaticales sin ningún tipo de orden o secuenciación y se ponen en práctica a base de actividades de traducción como la siguiente:

Ejercicio de conjugación

1. I take the book. 2. You (= tú) take the book. 3. You (= usted) take the pen. 4. The pupil takes an exercise-book. 5. We take the plate, etc. (Moll 1954: 27).

De este tipo de ejercicios se desprende una consecuencia negativa. El estudiante se ve obligado a establecer un paralelismo exacto entre las estructuras de su lengua materna y las de la lengua que está aprendiendo dando lugar a analogías inapropiadas. En el ejemplo que se indica, el alumno siempre traducirá al español el sujeto de la oración, obligatorio en inglés (yo cojo el libro, tú coges el libro...), cuando en español el sujeto es una función que se puede omitir en determinadas condiciones. Pero este rasgo del español no puede percibirse a partir de la simple traducción de una lista de oraciones. En definitiva, el estudiante inevitablemente incurrirá en el fenómeno denominado transferencia negativa o interferencia, traduciendo literalmente estructuras lingüísticas propias de su lengua materna al 
español, produciendo secuencias lingüísticas posibles pero que los hablantes nativos no utilizan y que les resultan casi incomprensibles, como por ejemplo, ¿Puedo conseguir yo la factura, por favor?, traducción literal de la fórmula empleada habitualmente en inglés para pedir la cuenta en un bar o restaurante (Can I havelget the bill, please?).

\section{Método Directo/Paradigma estructural}

Aunque ambos paradigmas parten de fundamentos teóricos sobre el concepto de lengua y de aprendizaje totalmente distintos, comparten muchos rasgos en la tipología de las actividades gramaticales que emplean.

El concepto de aprendizaje que subyace en el Método Directo considera, de forma puramente intuitiva y sin base científica, que el proceso de aprendizaje de una lengua extranjera es semejante al proceso de adquisición de la lengua materna. Dicho proceso consiste en la imitación de modelos lingüísticos, asociación del léxico a imágenes u objetos y en la inducción de las reglas gramaticales a partir de la observación de ejemplos. No hay explicaciones gramaticales explícitas, las reglas se obtienen a partir de la realización de las actividades sin referencia alguna, como es lógico, a la lengua materna del estudiante. Sin embargo, esta metodología carece de una teoría explícita sobre la naturaleza de la lengua, simplemente la trata de forma semejante a la metodología de Gramática y Traducción, es decir, como un simple conjunto de reglas y de vocabulario.

Partiendo de estas bases, el tipo habitual de ejercicio gramatical consiste en presentar un modelo lingüístico. Para que el estudiante lo asimile e induzca o extraiga la regla correspondiente debe repetirlo un número no determinado de veces en actividades como la siguiente:

¿De qué color es?

Ejemplo: cigarrillo/blanc El cigarrillo es blanco

1. mesa/negr.

2. lápiz/roj.

3. llave/amarill.

(Método Berlitz 1971: 24) 
Se espera que, mediante la repetición del modelo, el estudiante llegue a comprender la concordancia del sujeto con el atributo adjetivo en las oraciones copulativas.

El Paradigma Estructural es la primera metodología que parte de unos fundamentos científicos basados en la Lingüística y en la Psicología. El concepto de lengua parte de la lingüística estructural: una lengua es un sistema formado por un conjunto de unidades formales que están en relación de oposición. El concepto de aprendizaje parte de la psicología conductista: el aprendizaje de una lengua, un producto externo al individuo, consiste en adquirir hábitos lingüísticos a través de un proceso mecánico compuesto por tres etapas, estímulo-respuesta-refuerzo. Aunque estas bases son diferentes de los presupuestos del Método Directo, sin embargo, conducen a la misma concepción del proceso aprendizaje de una lengua extranjera: el estudiante debe realizar un proceso de inducción de las reglas a partir de la exposición a un número indefinido de input. Por esta razón, como ya se ha mencionado, el tipo de actividad gramatical es muy semejante al del Método Directo. Se presenta una estructura determinada y el estudiante la repite una serie variable de veces en ejercicios como el siguiente:

¿Cómo está Luis? Luis está bien

1. ¿Y tú?

2. ¿Y los niños?

3. ¿Y María?

4. ¿Y vosotros?

(Sánchez et al. 1974: 26)

La tipología de las actividades tanto del Método Directo como las del Paradigma Estructural presentan en común aspectos inadecuados. El primero de ellos, y el más importante, es la atención exclusiva a la forma dejando al margen el significado. En efecto, estos ejercicios de huecos consisten en la práctica puramente formal de una clase de palabra (un verbo, una preposición, etc.) o de un tipo determinado de estructura. De hecho, teniendo a la vista el modelo lingüístico para practicar, el estudiante puede resolver el ejercicio aunque haya significados que desco- 
nozca. No tiene que comunicar nada, simplemente debe repetir el modelo porque se le proporciona todo lo que necesita: la pregunta y la respuesta que ha de dar. Por otra parte, se muestra un uso de la lengua muy alejado de la realidad. Por citar algunos ejemplos, a la pregunta ¿Cómo está Luis?, la respuesta habitual no es Luis está bien sino simplemente bien, o a la pregunta ¿Cómo estás tú? la respuesta que suele darse en clase de ELE atendiendo al modelo es Tú estás bien, secuencia formalmente correcta pero incoherente desde el punto de vista del intercambio comunicativo. Por otra parte, ejercicios de este tipo carecen de toda coherencia o cohesión interna, no son nada más que un conjunto de oraciones cuyo número es indeterminado y depende del criterio del autor de los materiales.

La consecuencia de todo lo expuesto es que estos ejercicios solo tienen por objeto que se resuelvan de modo correcto, sin que el estudiante tenga la oportunidad o necesidad de comunicar nada, de entender y hacerse entender sobre algo que realmente sea de su interés. El alumno se convierte en un experto en resolver ejercicios, en conjugar o realizar bien las concordancias, en repetir modelos lingüísticos, etc. Pero a la hora de comunicarse en la segunda lengua encuentra serios obstáculos.

\section{Paradigma comunicativo}

Los tres paradigmas anteriores coinciden en la hipótesis de que una vez que el estudiante domine la gramática de una lengua extranjera podrá, como lógica consecuencia, comunicarse en esa lengua. Sin embargo, la realidad muestra que ese proceso habitualmente no tiene lugar. La evidencia de que el alumno de lenguas extranjeras no solo ha de aprender su gramática sino también a comunicarse en esa lengua fue uno de los desencadenantes del surgimiento del Paradigma Comunicativo.

El fundamento lingüístico del Paradigma Comunicativo se basa en las teorías mentalistas y cognitivas, que rechazan la hipótesis conductista sobre el aprendizaje de una lengua. Sin embargo, ambas corrientes lingüísticas discrepan en cuanto al modo de producirse ese aprendizaje. La teoría mentalista mantiene que existe una organización modular de la mente en la que se encuentra la facultad innata del lenguaje, que consis- 
te en un dispositivo de adquisición del lenguaje independiente de otros sistemas cognitivos involucrados en el uso de ese conocimiento lingüístico. Los modelos cognitivos, en cambio, consideran que la adquisición de una lengua es un proceso de aprendizaje basado en los mismos mecanismos en los que se fundamenta la construcción de cualquier otro conocimiento.

El concepto de aprendizaje del Paradigma Comunicativo procede de la psicología constructivista, teoría enmarcada dentro de la psicología cognitiva. El constructivismo concibe el aprendizaje humano como un proceso de constante construcción o reestructuración del conocimiento en general. La asimilación de un nuevo conocimiento se produce cuando el individuo puede conectarlo a un conocimiento previo, dando lugar así a un nuevo estado de conocimiento. Aplicando este planteamiento al aprendizaje de una lengua extranjera, este consiste en un proceso de reestructuración constante de un sistema lingüístico denominado interlengua. Esta interlengua se compone de una sucesión de estadios intermedios que se van reorganizando a medida que se asimilan nuevos conocimientos de la segunda lengua.

El proceso de aprendizaje de una lengua se activa a partir de su uso como sistema de comunicación, es decir, cuando se utiliza para transmitir significados. En este proceso el hablante recibe input y produce output. Por esta razón, las actividades para el aprendizaje de lenguas extranjeras del Paradigma Comunicativo pretenden generar situaciones comunicativas. Para el diseño de estas actividades se parte de un elenco de funciones lingüísticas (saludar y despedirse, dar y pedir información, expresar gustos...) y nociones asociadas a ellas, dando lugar a exponentes lingüísticos, es decir, expresiones lingüísticas que el estudiante de lenguas extranjeras ha de saber utilizar adecuadamente para conseguir sus intenciones comunicativas. Todo ello puede comprobarse en la actividad siguiente:

Levántate y pregunta la profesión a tus compañeros. Pregúntales también por qué quieren aprender espańol. Mira primero el ejemplo:

¿A qué te dedicas? Soy estudiante

¿Y por qué quieres aprender español?

Para viajar

(Equipo Entinema 2011: 8) 
Sin embargo, esta renovación profunda en el diseño de las actividades para practicar funciones lingüísticas no suele afectar a los ejercicios destinados en exclusiva a la práctica de la gramática. Estos suelen presentar una forma muy semejante a la de los modelos estructuralistas, como puede observarse en estas actividades:

Completa estos diálogos (con el artículo). Cuidado, también puede ser $\emptyset$.

1. ¿Está - señorita Hidalgo?

2. Buenos días, - señora Martínez.

3. Adiós. Hasta pronto, - señor Solchaga.

4. ¿- señores Martín, por favor?

5. Por favor, - señor Lozano?

etc.

(Miquel/Sans 1989: 27)

Completa con ser, estar, tener.

1. (yo) — un amigo muy simpático.

2. (tú) - mucho tiempo.

3. - médico cirujano. Trabaja en el hospital Gregorio Marañón.

4. (él) — africano. De Angola.

5. - 34 años, tres más que su mujer.

etc.

(Equipo Prisma 2002: 78)

Este tipo de actividades contribuye poco al aprendizaje de la gramática ya que proporciona un input disperso e inconexo. Obsérvese, por ejemplo, cómo en el ejercicio de Equipo Prisma la oración 1 puede resolverse de dos formas posibles: soy un amigo muy simpáticoltengo un amigo muy simpático.

Volvemos a encontrarnos con actividades cuya finalidad consiste en ser resueltas correctamente. El único camino que puede seguir el estudiante es el de recordar unas reglas previamente establecidas e intentar no equivocarse al aplicarlas para rellenar el hueco correspondiente. Esta práctica contribuye de manera insuficiente a una asimilación efectiva de la gramática. 


\section{Modelo de Procesamiento del Input}

El Modelo de Procesamiento del Input centra su investigación en el análisis de la primera etapa del proceso de la adquisición de una segunda lengua, es decir, el momento en el que el estudiante procesa el input de la lengua extranjera que aprende. El punto de partida de este modelo es la evidencia de que únicamente comprender el input no es garantía de que se produzca la adquisición de las formas gramaticales, dado que a menudo el estudiante lo procesa solo parcialmente.

Esta manera parcial de procesar el input se debe a ciertas estrategias que el alumno tiende a poner en marcha de modo intuitivo y casi automático y que suelen conducirlo a error. El Modelo de Procesamiento del Input describe cuáles son estas estrategias en una serie de principios como, por ejemplo, 'El Principio del Primer Sustantivo', según el cual los estudiantes tienden a interpretar el primer sustantivo o pronombre de una oración como el sujeto o agente. En un enunciado como Lo besa ella el estudiante extranjero tenderá a identificar el pronombre átono como el sujeto de la oración.

Para evitar esta manera de procesamiento no adecuada inducida por estas estrategias es necesario diseñar actividades gramaticales capaces de modificar y reconducir este modo de proceder del estudiante en su interpretación del input. De esta labor se ocupa la denominada Instrucción de Procesamiento, cuyo objetivo es proporcionar una instrucción gramatical en la que el input se manipule para que resulte más eficaz para la adquisición de la forma gramatical o, dicho de otro modo, manipular el input para que el estudiante no pueda recurrir a sus estrategias intuitivas para resolver el ejercicio.

Este tipo de ejercicios se denominan actividades de input estructurado. En estas actividades la novedad consiste en que no se propone una regla y a continuación se pone en práctica mediante la producción (output) del alumno, como sucede en los modelos anteriores que hemos revisado, en los que el estudiante practica los usos de una determinada forma gramatical pero sin entender su valor lingüístico. En las actividades de input estructurado, en cambio, el centro de atención es el input que reciben los estudiantes, cuyo valor o significado tendrán que interpretar o procesar sin exigirles todavía ningún tipo de producción de una determinada forma gramatical. Podemos ver una muestra de ello en el ejemplo siguiente: 
Decide qué forma verbal se corresponde con cada interpretación, como en el ejemplo.

Ayer iba a la farmacia, y cuando cruza-

ba / crucé la calle, escuché una voz que me llamaba...

Cuando volvíamos / volvimos a casa nos encontramos un maletín lleno de joyas...

Cuando la llevábamos / llevamos al hospital, dijo que ya se sentía bien y volvimos a casa... a. crucé Ya estaba al otro lado de la calle.

b. cruzaba No había terminado de cruzar.

a.............. El maletín estaba en su casa.

b............. El maletín estaba en la calle.

a............ Llegaron al hospital.

b............. No llegaron al hospital.

(Alonso et al. 2005: 129)

En esta actividad el estudiante no tiene que producir ninguna forma del indefinido o imperfecto sino que solamente debe interpretar su significado. Se le ofrece un mismo enunciado en el que las dos formas verbales son posibles; el alumno no dispone de más información en la frase o en el contexto que la contenida en la morfología de la propia forma gramatical. En consecuencia, si no se interpreta de modo correcto la forma verbal en cuestión no será posible resolver con éxito el ejercicio. Esta conexión de forma y significado constituye el objetivo de la Instrucción de Procesamiento para el diseño de actividades gramaticales y es la responsable de que se produzca la adquisición de una forma lingüística.

La Instrucción de Procesamiento realiza, como podemos comprobar, un cuidadoso diseńo de las actividades gramaticales que no se limita a ofrecer un repertorio de frases con huecos para completar. Cada uno de los ítems que componen una actividad de input estructurado está elaborado a partir de una serie de pautas que lo hagan eficaz.

\section{Conclusión}

La renovación de la gramática que se ha producido en los últimos ańos en la enseńanza de lenguas extranjeras con la elaboración de reglas gramaticales pedagógicas se extiende, con el Modelo de Procesamiento del Input, al diseño de las actividades de práctica gramatical. Efectivamente, estas no pueden seguir concibiéndose como un simple instrumento para la ejercitación o evaluación de los conocimientos de un 
alumno sino que deben integrarse en el proceso de enseñanza-aprendizaje como un procedimiento más que favorezca la adquisición de la lengua por parte del estudiante.

\section{Referencias}

Alonso, R. et al. (2005): Gramática básica del estudiante de español, Barcelona, Difusión.

BRUCART, J. (1998): «Gramática y adquisición en la enseñanza del español como lengua extranjera», en Actas del VII Congreso de ASELE: 17-43.

Doughty, C. y J. Williams (1998): Atención a la forma en la adquisición de segundas lenguas en el aula, Madrid, Edinumen, 2009.

Equipo Entinema (2011): Etapas. Etapa 1. Cosas, Madrid, Edinumen.

Equipo Prisma (2002): Prisma A1. Comienza, Madrid, Edinumen.

GARCía, S. (2001): «El papel y el lugar de la gramática en la enseñanza de E/LE», Forma, 1: 9-21.

Gómez del Estal, M. (2004): «La enseñanza de la gramática dentro del enfoque por tareas», Forma, 8: 82-107.

Martín Peris, E. (coord.) (2008): Diccionario de términos clave de ELE, Madrid, SGEL (versión on-line en http://cvc.cervantes.es/ensenanza/).

Matte Bon, F. (1999): «¿Cómo debe ser una gramática que aspire a generar autonomía y adquisición?», en Actas del IX Congreso Internacional de ASELE: 57-78.

Melero, P. (2000): Métodos y enfoques en la enseñanzalaprendizaje del español como lengua extranjera, Madrid, Edelsa.

MÉTodo Berlitz (1971): Español 1, Lausana, Berlitz.

Miquel, L. y N. Sans (1989): Intercambio 1, Barcelona, Difusión.

Moll, F. (1954): Curso breve de español para extranjeros, Palma de Mallorca, Moll.

Richards, J. y T. Rodgers (1986): Enfoques y métodos en la enseñanza de idiomas, Madrid, Edinumen, 2003.

SÁnchez, A. (1992): Historia de la enseñanza del español como lengua extranjera, Madrid, SGEL.

- et al. (1974): Español en directo 1, Madrid, SGEL.

VanPatten, B. (1996): Input Processing and Grammar Instruction: Theory and Research, Norwood, New Jersey, Ablex Publishing Corporation.

- (ed.) (2004): Processing Instruction: Theory, Research, and Commentary, Mahwah, New Jersey, Lawrence Erlbaum Associates. 


\title{
LA CALIDAD DE LA DESCRIPCIÓN EN LA PEDAGOGÍA DE MODELO \\ DE LA PARFAICTE MÉTHODE POUR ENTENDRE, ESCRIRE, ET PARLER LA LANGUE ESPAGNOLE (1596)
}

\author{
Covadonga López Alonso \\ (Universidad Complutense de Madrid)
}

La noción de 'calidad' aplicada a los estudios gramaticales ha evolucionado con el devenir de los siglos desde de la Antigüedad grecolatina, los escolásticos de la Edad Media y los grandes humanistas del Renacimiento (Ahlqvist 1992; Auroux 1992, 1994); estos últimos se alejan de la noción de una gramática reflejo de la realidad y una percepción universalista del lenguaje — con sus cinco etapas en la relación 'ratio'/'modus' essendi, intelligendi, signandi, significandi, consignificandi- y renuevan en el XVII la enseñanza de las lenguas vernáculas, lo que implicará una regresión del latín clásico a favor del uso de las lenguas modernas y, en consecuencia, empezarán a aparecer descripciones morfológicas y sintácticas propias de cada una de las lenguas aunque imitando, en su mayoría, los modelos grecolatinos. La gramática de la que hoy nos ocupamos está a medio camino entre ambas tendencias. Por una parte, tal como se desprende de su análisis, nos encontramos con una obra en la que se latiniza la descripción del español —endogramaticalización (Auroux 1992, López Alonso y Séré 2000: 122-124)—, falseando, en consecuencia, la percepción semántica de 
los procedimientos descritos; por otra parte, este método del español como lengua extranjera para los franceses, aunque corresponde, sin lugar a dudas, a una pedagogía de modelo, anuncia (i) una defensa del aprendizaje de las lenguas, y (ii) una didáctica de la comprensión escrita en la que se busca la integración de los conocimientos gramaticales del español con los usos, costumbres y cultura del país.

Voy a presentar, en primer lugar y muy brevemente, la evolución de las propuestas educativas en la didáctica de las lenguas extranjeras hasta el siglo XVII; en segundo lugar, haré una breve descripción del latín como modelo de enseñanza de las lenguas extranjeras en Francia, con referencia expresa al español, para centrarme, finalmente, en La Parfaicte Methode y la relación que se establece entre una gramática de autoridades y su contextualización en los ejemplos, anunciando los nuevos modelos metodológicos del siglo XVII.

\section{Sociedad y política en la enseñanza de las lenguas extranjeras hasta el siglo XvII}

Los orígenes de la enseñanza de las lenguas extranjeras (LE) se remontan a la maldición de Babel y a una Mesopotamia que fue escenario multilingüe en el antiguo Oriente ante la necesidad de hablar y entender las lenguas, ya sea por cuestiones de prestigio, culturales, económicas, comerciales, militares, diplomáticas, religiosas o, simplemente, por razones sociales de comunicación (López Alonso 2006).

Los primeros testimonios escritos sobre la didáctica de las LE podemos localizarlos en el tercer milenio antes de nuestra era, en acadio, lengua materna de asirios y babilonios, y que, según prestigiosos investigadores, pudo servir inicialmente como lingua franca en los intercambios comerciales entre los mercaderes en el Mediterráneo oriental compuesto de diferentes etnias y culturas durante unos siete siglos. El acadio era la lengua diplomática de Egipto hasta Anatolia y Levante (Manqueen y Asher 1994) y esta lengua, tal como se conserva en las tablillas de arcilla encontradas en las ruinas de las antiguas ciudades, fue enseñada por los escribas como lengua extranjera en las escuelas extramesopotámicas, iniciando a los alumnos en el arte de aprender en acadio la escritura cuneiforme, su pronunciación, el vocabulario y la gramática, al tratarse de una lengua escrita de contacto más que una lengua de uso (Márquez 2004). 
El estudio de las LE puede rastrearse también desde la Antigüedad a la Edad Media a través del mundo clásico y el ámbito de influencia del griego en el Imperio Romano, de la pluralidad lingüística del Imperio Bizantino, del universo musulmán o de las pizarras visigodas que abren la puerta a los pergaminos altomedievales del castellano (Velázquez Soriano 2004, Bádenas et al. 2004). En Europa, hasta el siglo IX, el latín y el griego eran las dos lenguas clásicas que se estudiaban por excelencia, centrándose estas reflexiones en la transmisión, recepción y circulación de los textos antiguos; recuérdese la clasificación de las lenguas en bárbaras y sagradas o cultas — griego, latín, hebreo-y de qué manera la administración romana, que solo consideraba al latín como la lengua nacional académica y comunicativa, valoraba la enseñanza del griego como segunda lengua, ignorando las restantes (Marrou 1960, Percival 1992, Germain 1993).

El Renacimiento rompe con el modelo grecolatino, inaugura el estudio de las lenguas vernáculas (Ahlqvist 1992) y el latín pierde su estatuto social y lingüístico, pasando a la categoría de lengua no hablada. Hasta el siglo XVII, con excepción del latín eclesiástico, el latín sigue siendo el modelo de descripción gramatical de enseñanza de las lenguas y disciplina necesaria para la formación del espíritu, de lo que es buena prueba la importancia de Aristóteles y Platón en la filosofía del Renacimiento o la función del latín en la difusión del Humanismo en Europa como materia obligada en la educación renacentista, según se desprende, a modo de ejemplo, de los Ensayos de Michel de Montaigne (Livre I, cap. Xxvi). En ese periodo renacentista, además del estudio real de las lenguas, aparecen nuevas teorías sobre la diversidad y el origen de las lenguas y esas propuestas de clasificación sientan las primeras bases del comparativismo (Metcalf 1974; Germain 1993; López Alonso y Séré 2000).

\section{El latín, modelo de enseñanza de lenguas extranjeras en Francia en el siglo XVI. El caso de La Parfaicte Methode (1596)}

Como es bien conocido, el establecimiento del francés y su enseñanza tiene como fecha de nacimiento Les Serments de Strasbourg —año 842 - documento en el que se oficializa como lengua popular de uso, 
pasando el latín a convertirse en lengua extranjera culta, situación que se va asentando definitivamente en los siglos siguientes. Bajo el reinado de Louis XII y la Ordonnance de Villiers-Cotterêts (1539), el francés se convierte en la lengua obligada de uso administrativo y civil, aunque el estudio del latín sigue ocupando un lugar preferente en la enseñanza de las altas clases sociales y hasta la segunda mitad del siglo XVII no se implantará definitivamente el estudio del francés como lengua materna ni se fomentará el aprendizaje de las lenguas extranjeras (Cohen, 1973, Puren 1988).

Siguiendo a P. Riché (1979), gran especialista de estos estudios, en la enseñanza del latín como lengua segunda se aplica una pedagogía de modelo con un medio de enseñanza por inmersión, ya que casi toda la docencia se hacía en latín, canalizado su estudio en cuatro grandes campos: (i) la lectura, (ii) el latín oral (iii) la gramática y (iv) el vocabulario. En la lectura, se continúan las orientaciones de las escuelas romanas: de la letra a la sílaba; de la sílaba a las palabras y, de estas últimas a las frases, aprendiéndose de memoria los Salmos que los estudiantes recitaban y cantaban al mismo tiempo. El latín oral se aprende con textos, proverbios y diálogos contextualizados que se memorizan, utilizando también para ello el procedimiento pregunta/respuesta. Las gramáticas Donat y la de Prisciano son, a su vez, los modelos seguidos, identificando las ocho partes del discurso, los géneros, los casos y las conjugaciones. En cuanto al vocabulario, el estudio de glosarios alfabéticos o temáticos con palabras bíblicas o de uso general se continuaba con pequeños textos que se recitaban también de memoria.

Este modelo de enseñanza del latín como lengua extranjera es el que va aplicarse en la enseñanza/aprendizaje de las lenguas vivas a lo largo de toda la Edad Media e incluso hasta los albores del siglo XVII, lo que marcará esos estudios por la importancia que se da a las reglas gramaticales y al uso del vocabulario que, desde el plan metodológico, seguirán una pedagogía de modelo de las escuelas romanas a las que acabo brevemente de referirme y, tal como vamos a ver, marca la obra de Charpentier.

La BICRES (Niederehe 1994: nota 806, p. 255) recoge dos ediciones de La Parfaicte méthode; una datada de 1596, siguiendo las indicaciones de Morel Fatio (1900:93) y Ramajo Caño (1987:239), de la cual se 
conservan dos ejemplares en la Biblioteca Nacional de Paris (BNP); otra, de la que existe un solo ejemplar, en la Biblioteca Nacional de Madrid de 1597. ${ }^{1}$ La obra se presenta como anónima y consta de 97 folios y uno de erratas. Su título completo es La parfaicte méthode povr entendre, escrire et parler la langue Espagnole, diuisée en deux parties. La première contient briefvement les reigles de Grammaire. La seconde, les recherches des plus beaux enrichissemens de la langue que seruent à la composition et traduction. Premiere partie. A Paris, chez Lucas Breyel, au Pallais, en la gallerie par où va à la Chancellerie, M.D.XCVII. En ambas bibliotecas no se conserva más que la primera parte.

La autoría de esta obra, atribuida a Nicolás Charpentier, se basa en una anotación hecha a mano por el impresor en la copia que se conserva en la Biblioteca Nacional de París. Morel-Fatio (1900) señala que el nombre de Charpentier coincide con el de un ahorcado que había formado parte de un complot pro-español en 1597; de ser así, el texto tendría que ser anterior a 1597, y podría, a su vez, explicar el ostracismo al que fue sometido.

Esta obra se ofrece al lector como la primera gramática del español para franceses con un enfoque pedagógico que, como veremos a continuación, responde a las condiciones sociohistóricas de la época, marcadas por una pedagogía de modelo de excelente calidad que explica la preceptiva gramatical y la selección de los ejemplos (Alonso 1951; López Alonso y Séré 2000).

\section{La pedagogía de modelo en La parfaicte Methode pour entendre, escrire et parler la langue espagnole (1596)}

Un estudio de la didáctica de las lenguas (López Alonso 2006) exige detenerse, al menos, en dos tipos de observaciones: (i) qué finalidad tiene la obra y su orientación gramatical, y (ii) cuál es la función del ejemplo; estos dos parámetros son la base de las relaciones pedagógicas que definen a este método.

1 Texto por el que cito. 


\subsection{Función de la gramática}

Si nos atenemos al paratexto de la obra (Genette 1981, 1987), ${ }^{2}$ el título en sí mismo marca su carácter y finalidad: se trata de una metodología de la comprensión y expresión escritas, en la medida en la que el término 'parler?' aparece marcado con interrogación en el prefacio al lector. El carácter normativo orienta y sintetiza la finalidad del método y el paratexto autorial es una figura retórica propia de la época: «m’estất tombé entre les mains ce premier traicté de la langue Espagnole». Los títulos de los capítulos y sus apartados son, a su vez, temáticos y dan cuenta del objeto de la descripción lingüística de modo que el estudioso pueda seguir sin dificultad la relación que se establece entre la definición y uso gramaticales y su función didáctica. A su vez, el prólogo al lector señala la funcionalidad de la obra en su conjunto, siendo una forma didáctica de introducir al estudiante en la dimensión científica del objeto de estudio y contribuyen a la importancia y seriedad del método.

En un manuscrito de la Biblioteca de Berna del siglo $\mathrm{Ix}^{3}$ se define la gramática como «la ciencia del bien decir [...] de bien escribir y de bien hablar $[\ldots]$ que consiste en un arte de preceptos y de reglas». Esta antigua noción preceptiva preside el título de Charpentier en el que el aprendizaje de la gramática se impone como método no solo para escribir sino también para comprender correctamente la lengua proponiendo (i) la función de la memoria y la repetición en el aprendizaje, y (ii) el modelo de las descripciones latinas y griegas como imitación (pp. 27-28).

Or des trois fortes d'accens que pratiquent les Grecs, nous nous contenterons de cognoistre simplement la place $\&$ le lieu de l'aigu: car quant au graue $\&$ circonflexeils ne viennent à propos en ce lieu.

No debe olvidarse, además, la importantísima relevancia que tiene el descubrimiento de América para el aprendizaje del español, lo que explica que a finales del siglo Xvi esta lengua se convierte en un instrumento de comunicación imprescindible. Comprender español, además, responde no

2 Aplico la definición de G. Genette (1981) que considera que esta noción remite a toda una serie de elementos (nombre del autor, título de la obra, de los capítulos, dedicatoria, prefacios, epígrafes, notas, edición, tipo de colección, ilustraciones...) que dan forma al texto y lo convierten en libro.

3 Reproducido en Riché (1979: 231). 
solo a una necesidad de saber sino, sobre todo, entenderse con otros mundos y culturas. Este imperativo comunicativo, sin embargo, no se refleja en el método que, siguiendo los modelos gramaticales de los siglos anteriores, se centra en la lengua escrita y en el empleo de ejemplos de proverbios y de textos literarios (p. 64)

Mais auant que passer aux coniuguaisons, faut noter la difference qu'il y a entre ce verbe soy \&t estoy, d'autant que soy signifie \&t denote la substance \& qualité de la chose, comme es bueno, il est bon: mais estar signifie lieu, comme estoy en casa, la distinction se verra aisément par cest exemple de Boscan.

Del cocodrilo es su uida que de dia esta en la tierra

Nous le tournerions ainsi, c'est la vie du Cocodrile d'estre de iour en terre: [...]

El autor recurre a la analogía como procedimiento descriptivo, imitando las propuestas de E. A. de $\mathrm{Nebrija}^{4}$ con agudas críticas a las Osservationi (1565) de Miranda (p. 63):

Le Miranda estimant (à mon aduis) que ce verbe n'aye point de gerondif usité en cette langue non plus qu'en la Latine, n'en faict aucune mention. Mais la lecture des Autheurs nous enseigne le contraire.

Y siêdo el lleuador sere el lleuado.

Esta pedagogía de modelo, tanto de la gramática de Nebrija como de las latinas y griegas, se observa no solo en el metalenguaje empleado sino, muy especialmente, en la manera de tratar las categorías gramaticales, presentando las reglas y la comparación entre las dos lenguas 5 (p. 51):

Le relatif que, sert aucunefois de particule et non de relatif, ce qui ne sçauroit se cognoistre par aucune regle certaine, sinon que nous pouuốs dire qu'il sert de particule toutes \& quátefois qu'il vient apres un verbe, comme en cest exêple de Boscá.

$\mathrm{Vi}$ que cuando me formara

ningun estado me diera.

Que nous pouuons ainsi tourner,

Je vis que quand il me formoit

Aucun estat ne me donnoit.

4 No cita, sin embargo, a Villalón, aunque utiliza algunas de sus descripciones y ejemplos. Por cuestiones de espacio, no puedo abordar en este estudio la influencia de estas gramáticas ni sus críticas continuas al Osservationi de Miranda (cf. López Alonso y Séré 2000: 123-124).

5 Para una visión detallada de la organización gramatical de la obra, cf. López Alonso y Séré (2000: 125-130). 
El estudio contrastivo del español en relación con el francés se apoya en una pedagogía de modelo como principio de autoridad, de la que destacaría las seis características siguientes:

(i) se trata de una descripción del español que, imitando los modelos grecolatinos y españoles, se compara siempre con el francés por medio de la traducción;

(ii) tiene un marcado carácter preceptivo aunque, en relación con otras obras de la época, se evita el abuso de reglas y se intenta que sea un reflejo de la realidad de la lengua más que la normativa de un sistema gramatical;

(iii) los títulos de los capítulos siguen las obras al uso: una primera parte de ortografía y fonética y una segunda que corresponde a las partes de la oración; ${ }^{6}$

(iv) las descripciones están orientadas a la escritura;

(v) se parte de las nociones y propiedades generales de las categorías gramaticales y se concentra, a continuación, en aspectos más particulares; $y$

(vi) como veremos a continuación, los ejemplos son proverbios y citas literarias de autores consagrados; sin embargo, las explicaciones están aplicadas a la lengua en general en un intento de contextualizarla y, sin duda, esto es uno de los mayores intereses de la obra.

\subsection{El uso del ejemplo literario}

La Parfaicte Methode recurre a cuatro tipos de ejemplos: (i) palabras, (ii) frases, (iii) proverbios (López Alonso y Séré 2000: 130-131), y (iv) prosa y verso literario. Voy a referirme a estos últimos.

Los ejemplos literarios, como ya he señalado, se utilizan para ilustrar una regla general del español y se ofrecen siempre con la traducción en francés, procedimiento que al mismo tiempo facilita (i) un conocimiento y divulgación del espańol, y (ii) el acceso a una cultura ilustrada.

6 En la segunda parte desaparecida se anuncia la sintaxis y los ejercicios de composición y de traducción. 
Un breve recorrido sobre la gramatología del siglo xvi y, en especial, en la enseñanza del español, ${ }^{7}$ refleja cómo el contexto sociohistórico y una pedagogía de modelo grecolatino impiden, en una cierta medida, un movimiento gramatical renovador, de ahí que no es extraño que esta obra utilice el ejemplo literario para dar forma a una didáctica prescriptiva de la lengua. Si bien la literatura como autoridad y conducta que debe imitarse es consecuencia de los modelos anteriores, en La Parfaicte Methode se ofrece como un medio de adquisición de (i) un uso normativo del español para conservar su perfección y, al mismo tiempo, (ii) un instrumento indispensable para la adquisición de la lengua literaria, aspecto este último que sin duda se desarrollaría en la segunda parte de la obra, tal como parece anunciar en la advertencia al lector:

[...] ie mes-forceray de ne vous faire gueres attendre apres l'autre, lequel n'estant rempli des difficultez de Grammaire, comme le present, ains des plus belles $\&$ curieuses recherches de cette lágue, fera sans doubte aussi bien, ou mieux receu en vostre endroict, que ce premier.

Las explicaciones gramaticales —apartado 3.1- aseguran un buen aprendizaje del sistema de la lengua — no exento de comparaciones innecesarias con el latín y el griego-, con una progresión y coherencia correctas $\mathrm{y}$, además, la traducción al francés facilita al estudiante una intercomprensión modélica que le servirá de apoyo para el buen uso. Servirse de

7 En la BICRES se encuentra una excelente bibliografía cronológica de gramáticas y lexicografía del español publicadas en España y en Europa, con fuentes bibliográficas del siglo XVI, estudios e índices que hemos consultado para este trabajo y de la que destacaremos que las primeras gramáticas del español como lengua extranjera (ELE) aparecen en los Países Bajos, sin duda debidas a razones de tipo sociopolítico: Util y breve institución para aprender los principios y fundamentos de la lengua Española (Anónimo 1555), Gramatica de la Lengua Vulgar de España (Anónimo 1559); Gramática castellana. Arte breve y compendiosa para saber hablar e escribir en la lengua castellana congrua y deçentemente (Villalón 1558); y Conjugaciones, règles et instructions moult propres et nécessairement requises pour ceux qui désirent apprendre francois, espagnol, italien et flamen (Meurier 1558). En las décadas siguientes, surge un gran número de estudios sobre el español motivadas también por la necesidad de entender y hablar esa lengua - como Osservationi della lingua Castigliana, di Giovanni Miranda, divise en cuatro libri: en quali s'enseigna con gran facilita la perfetta lingua Spagnuola. Con due tavole: l'una de capi essentialli \& l'altra delle cose notabili (Miranda 1565) — Retenemos la fecha de 1597, año de publicación de las gramáticas de Charpentier y de Oudin - Grammaire espagnolle expliquée en françois_, gramáticas destinadas a la enseñanza del español para franceses. Por cuestiones de espacio no me es posible abordar la diferencia entre estas dos gramáticas (cf. B. Lepinette 2000). 
obras y autores clásicos para establecer un modelo de lengua es una práctica pedagógica que se encuentra en los primeros manuales didácticos de la historia y, en este sentido, es el procedimiento que sigue este método, proponiendo la autoridad para alcanzar el conocimiento lingüístico. Por ello, la literatura se utiliza como texto ideal para ejercitarse en las tareas de 'entender' y 'escribir' la lengua: el método defiende, en primer lugar, que es imprescindible un dominio del sistema gramatical para, en un segundo lugar, apoyarse en la lengua literaria como modelo. Esta propuesta didáctica obliga al estudiante a ejercitarse en la comprensión escrita aunando, con eficacia, el aprendizaje del sistema gramatical con la imitación del buen uso literario.

La presencia de autores y textos a los que se recurre demuestra que el autor no solo tiene un excelente conocimiento del español, sino también de su literatura. Se indica, además, de continuo, la finalidad didáctica como objetivo prioritario y se logra, en consecuencia, un equilibrio entre las descripciones gramaticales y la finalidad educativa perseguida. El ejemplo literario (i) justifica el interés social y cultural del método y sus fines, (ii) no entorpece la reflexión gramatical, (iii) es un referente privilegiado para la explicación de la cultura, y (iv) sirve para justificar el uso y defensa de la lengua. Creo, por ello, que estos testimonios literarios tienen también en común la pretensión de realzar los fundamentos y la profundidad de la obra. Los autores se utilizan con una erudición muy controlada privilegiando la historia de la lengua, su unidad, valores e importancia. El ejemplo, por ello, no es gratuito, inútil o excesivo; su función es, a la vez, formativa e informativa en la medida en la que (i) cubre una función explicativa que, partiendo de la categoría gramatical, da cuenta del uso, (ii) tiene una función erudita y divulgativa, ya que se presenta como una muestra de perfección, elegancia y buen uso de la lengua.

Charpentier recurre a su extenso conocimiento humanístico y cita, por orden de aparición a Boscán, don Alfonso el Sabio, La crónica de Don Rodrigo, las Partidas de don Pedro el Cruel, Alonso de Ercilla — «que se peut appeller le Ronsard des Espagnols»—, la Diana de Montemayor, las Epistolas de Guevara, La Celestina, el Romance de Belardo, Garcilaso de la Vega, Juan de Mena y romances como el Romance de Antequera y el de la Crónica de Troya. Los ejemplos más frecuentes y atinados son de Boscán y, a pesar de que este autor no sea hablante nativo español, es muy alabado 
por Charpentier. Conoce muy bien su obra y de sus citas se desprende que valora el verso endecasílabo («Abría los sus ojos ciegamente»); sin duda, su verso claro, diáfano y sencillo, sin apenas artificio literario, debe responder al ideal de lo natural, tal como puede observarse en este ejemplo del poema Hero y Leandro:

Los nombres de los quales eran estos.

era Leandro el del y el della Hero

El autor demuestra un excelente conocimiento del espańol, selecciona cuidadosamente los ejemplos literarios para que no sean una transgresión del orden sintáctico ni se vea alterado el orden canónico de la frase: son textos concisos, que focalizan muy bien el uso de la lengua, presentando, en primer lugar, la forma gramatical y, a continuación, el ejemplo en su empleo habitual. Del análisis se desprende que se defiende un empleo normativo de la lengua ratificado con un uso literario sin afectación alguna.

\section{A modo de conclusión}

La Parfaicte Methode se dirige a un público ilustrado y su finalidad es el acceso a la expresión y comprensión escritas, siguiendo una pedagogía de modelo grecolatino aplicado al español en contraste con el francés, con cuidadosas descripciones que muestran las semejanzas y diferencias de los dos sistemas lingüísticos y sus posibles interferencias, siendo un buen ejemplo de calidad normativa y descriptiva.

La obra utiliza tres tipos de ejemplos: de la lengua general, proverbios y literarios. Todos ellos se ofrecen como modelos de regularidad, sirven para definir y analizar el sistema lingüístico y son una buena ayuda para entender la organización y estructuras gramaticales, cumpliendo una triple función didáctica: formativa, informativa y de estilo. Estos tres valores se conjugan sabiamente en la presentación de las categorías gramaticales: se introduce la noción del objeto de estudio y se describe y se contextualiza. La utilización del ejemplo literario no es gratuita, falsa o simplemente erudita, sino que se entabla un diálogo productivo entre el sistema y el uso, ayudando, en muchos casos, a entender la complejidad del fenómeno.

Creo que la calidad y pertinencia didáctica del ejemplo literario en $\mathrm{La}$ Parfaicte Methode es uno de los aciertos de la obra que la hace menos pres- 
criptiva y más descriptiva. Habrá, sin embargo, que esperar hasta finales del siglo Xviı para que la didáctica de las lenguas adquiera el estatuto de una disciplina propia y se elaboren con rigor una ciencia de la educación y una teoría general de la enseñanza de las lenguas extranjeras que sostienen que (i) es necesario un buen conocimiento de la lengua materna para poder interesarse en el estudio de otras lenguas, (ii) deben ser aprendidas no solo por razones culturales sino también por necesidades sociales y de comunicación, (iii) el aprendizaje tiene que hacerse según el uso y no las reglas gramaticales, (iv) los ejemplos no deben ser solo literarios sino de la lengua general, y (v) hay que abandonar las pedagogías de modelo, esbozándose unas orientaciones sociopragmáticas que alcanzarán su pleno rendimiento en el siglo xx.

\section{Referencias}

Ahlqvist, A. (1992): «Les premiers grammaires des vernaculaires européens», en S. Auroux (ed.), Histoire des idées linguistiques, París, Mardaga, vol. 2: 107-114.

Alonso, A. (1951): "Gramáticos espańoles y franceses de los siglos XVI, XVII y XVIII», Nueva Revista de Filología Hispánica, 5: 1-37.

Auroux, S. (1992): «Introduction. Le processus de grammatisation et ses enjeux», en S. Auroux (ed.), Histoire des idées linguistiques, París, Mardaga, vol. 2: 11-64.

- (1994): La révolution technologique de la grammaticalisation, Lieja, Mardaga. Bádenas de la Peña, P., S. Torallas Tovar, R. E. Luján y M.a A. Gallego (eds.) (2004): Lenguas en contacto. El testimonio escrito, Madrid, Consejo Superior de Investigaciones Científicas.

Cohen, M. (1973): Histoire d'une langue: le français, París, Éditions Sociales.

Genette. G. (1981): Palimpsestes, París, Seuil.

- (1987): Seuils, París, Seuil.

Germain, C. (1993): Évolution de l'enseignement des langues: 5000 ans d'histoire, París, CLE International.

Lepinette, B. (2000): "À propos de deux grammaires pour l'enseignement de l'espagnol aux Français», en B. Bagola (ed.), La Lingüistica española en la época de los descubrimientos, Romanistik in Geschichte und Gegenwart, Beiheft 5, Hamburgo, Helmut Buske Verlag: 107-120.

López Alonso, C. (2006): «La enseñanza de lenguas extranjeras: de la pedagogía del modelo a la pedagogía del proyecto», Caminos actuales de la Historiografía Lingüistica, vol. II: 927-941. 
López Alonso, C. y A. Séré (2000): «La parfaicte méthode (1596): Primer método de español como lengua extranjera para franceses», en B. Bagola (ed.), La Lingüistica española en la época de los descubrimientos, Romanistik in Geschichte und Gegenwart, Beiheft 5, Hamburgo, Helmut Buske Verlag: 121-133.

Manqueen, J. G., y R. E. Asher (eds.) (1994): Encyclopedia of Language and Linguistics, vol. 1, Oxford.

MÁrquez Rowe, I. (2004): «Reflexiones sobre el acadio como lengua de contacto en el Antiguo Oriente», en Bádenas et al. (eds.), Lenguas en contacto. El testimonio escrito, Madrid, Consejo Superior de Investigaciones Científicas: $17-34$

Marrou, H.-I. (1960): Histoire de l'éducation dans l'Antiquité, París, Seuil.

Metcalf, G. J. (1974): «The Indo-European Hypothesis in the Sixteenh and Seventeenth Centuries», en D. Hymes (ed.), Studies in the History of Linguistics. Traditions and Paradigms, Bloomington y Londres, Indiana University Press.

Morel-Fatio, A. (1900): Ambrosio Salazar et l'étude de l'espagnol en France sous Louis XIII, París, Picard et Fils.

Niederehe, H.-J. (1994): Bibliografía cronológica de la lingüistica, la gramática y la lexicografia del español (BICRES). Desde los comienzos hasta el año 1600, Ámsterdam-Filadelfia, J. Benjamins.

Percival, W. K. (1992): «La connaissance des langues du monde», en S. Auroux (ed.), Histoire des idées linguistiques, vol. 2, París, Mardaga: 226-238.

Puren, Ch. (1988): Histoire des méthodologies de l'enseignement des langues, París, Nathan-CLE International.

Ramajo Caño, A. (1987): Las gramáticas de la lengua castellana desde Nebrija a Correas, Salamanca, Universidad.

Riché, P. (1979): Les écoles et enseignement dans l'Occident Chrétien de la fin du $V^{e}$ siècle au milieu du XI siècle, París, Aubier Montaigne.

Velázquez Soriano, I. (2004): Las pizarras visigodas. (Entre el latín y su disgregación. La lengua hablada en Hispania, siglos VI-VIII), Beltenebros, 8, Fundación Instituto Castellano y Leonés de la Lengua y Real Academia Española. 



\title{
NOTAS SOBRE LA SINTAXIS DE DOERGANGK
}

\author{
Emilio Ridruejo Alonso \\ (Universidad de Valladolid)
}

\section{Introducción}

Heinrich Doergangk (muerto aproximadamente en 1617) es autor de tres gramáticas de lenguas romances, del francés, del italiano y del español, las tres destinadas a la enseñanza a alumnos alemanes. Las obras, escritas en latín, fueron publicadas en Colonia, las Institvtiones in lingvam gallicam (ILG) y las Institvtiones in lingvam italicam (ILI) en 1604; las Institvtiones in lingvam hispanicam (ILH) en 1614. Las gramáticas tienen una base teórica común, pero también características distintas en su extensión (mucho mayor en las obras sobre el francés y el español), en su composición (con capítulos específicos en cada obra) y en los enfoques descriptivos de algunos apartados. Aunque van fechadas en el mismo año, 1604, ${ }^{1}$ las Institvtiones in lingvam gallicam debieron recibir una redacción anterior a las Institvtiones in lingvam italicam, pues en esta última obra hay frecuentes remisiones a lo incluido en el tratado sobre el francés, y no de carácter genérico, sino mediante la cita exacta a las páginas correspondientes. La gramática francesa parece ser que también sirve de modelo a la española, en su organización y en una parte importante de los contenidos. No obstante lo anterior, hay diferencias en las tres obras: el tratado italiano constituye

1 La epístola dedicatoria de $I L G$ está datada el 1 de febrero de 1604 y el Prólogo de ILI el 29 de marzo del mismo año. 
esencialmente un resumen de la obra sobre el francés y la gramática del español supone, tal como hemos señalado en otro lugar (Ridruejo 2010a y b), la incorporación al mismo esquema de materiales diferentes que proceden de otros tratados sobre el español.

\section{La organización de la materia gramatical}

Frente a las gramáticas latinas, ${ }^{2}$ las obras destinadas a la enseñanza de lenguas modernas publicadas a lo largo de los siglos XVI y XVII prestan escasa la atención a la sintaxis, en comparación con la morfología. ${ }^{3}$ Sin embargo, Doergangk en sus tratados dedica a la sintaxis una autonomía y una atención mucho mayor de lo habitual (Swiggers 2008: 372). Ya en el apartado preliminar, idéntico en las tres obras, Doergangk incluye la sintaxis entre los componentes necesarios que debe conocer un lingüista (ILG: 28; ILH: 1; ILI: 6). Además, la extensión de las secciones de sintaxis es muy considerable: en las Instituciones francesas abarca desde la página 312 hasta el final del libro (pág. 523); en las Instituciones italianas, el apartado comienza en la página 81 e igualmente llega hasta la invocación final de la página 114 y en la obra sobre el español, la sintaxis abarca desde la página 143 hasta la página $224 .^{4}$

En las tres gramáticas se define la sintaxis de manera similar, aunque no exactamente igual: "congrua \& recta dictionum inter se coniunctio» (ILG: 28); «recte inter se dictionum compositio \& structura» (ILI: 6) «legitima structura \& compositio verborum \& dictionum» (ILH: 1). Es decir, se propone la sintaxis de manera no muy diferente a como lo hacen algunas gramáticas latinas, ${ }^{5}$ siempre teniendo en cuenta la combinación de pala-

2 El libro cuarto de las Introductiones latinae de Nebrija se dedica a «la construction de las partes de la oracion entre si» (Nebrija 1996 [ca. 1488]: 130) y en la Gramática del jesuita Manuel Alvares, De Institvtione grammatica libri tres (1596 [1572]), la obra de gramática latina más al uso en las escuelas católicas fuera de España, todo el libro segundo, el central de la obra, está dedicado a «De octo partium orationis constructione», a la sintaxis. Lo mismo sucede en la gramática latina de Ramus.

3 Vivier (1566) no se ocupa de la sintaxis y Garnerius (1591: 77) deja su conocimiento al uso: «non potius $\&$ exercitatione quam arte acquiritur».

4 No faltan tampoco las observaciones sintácticas en otros apartados, especialmente en el último, «De partibus indeclinabilibus».

5 Por ejemplo, Alvares: «recta partium orationis inter se compositio» (1596 [1572]: 257). 
bras y el criterio de corrección o adecuación. Doergangk excluye, sin embargo, lo que tradicionalmente se denominaba sintaxis figurada (solecismo, zeugma, silepsis, etc.). ${ }^{6}$

\section{El orden}

En la presentación de la construcción que realiza Doergangk son centrales, como no podía ser menos, los componentes clásicos de la sintaxis latina: el orden, la concordancia y el régimen. Los capítulos de sintaxis comienzan en las gramáticas francesa y española con una regla general que trata del orden de las partes de la oración: «De ordinatione partium orationis inter se» (ILG: 312; ILH: 243). Señala el gramático en la obra francesa que el nombre en nominativo se antepone siempre al verbo y tras el verbo aparecen el adverbio y las preposiciones (si es que están presentes); a continuación se pone el caso oblicuo (genitivo, dativo, ablativo, acusativo). Esta misma regla es repetida en la otra gramática aunque, obviamente, no es la más adecuada para dar cuenta del orden de palabras del español. En el tratado sobre el italiano falta la regla general, aunque sí que se expone lo básico de su contenido al ocuparse del nombre. ${ }^{7}$ Así como Ramus en su Grammaire (1572) sobre el francés dedicaba, siguiendo a Varrón, largos capítulos a la anomalía (Chevalier 1968: 270), Doergangk, una vez formuladas las reglas generales, presenta con detalle los casos especiales. Las reglas del orden son precisadas con numerosas observaciones que, por ejemplo, para el francés atañen a la posición del nombre en la interrogación (ILG: 417), a los mandatos (ILG: 313; 499) o a construcciones pronominales (ILG: 441).

La posición de los elementos oracionales no agota el orden y, tras este apartado de carácter general, en las tres obras continúa la sintaxis, tal como hacen otros tratados gramaticales, latinos como los de Nebrija, Alvares, o

6 No obstante, Doergangk trata de la elipsis. Describe como supuestos de elipsis en español aquellas construcciones en las que el artículo está presente junto a un complemento preposicional, pero falta el sustantivo, referido previamente: «He leydo los libros de Plato, mas los de Mariana no he visto. Los de Mariana, pro los libros" (ILH: 146). Este tipo de construcciones son comparadas con las correspondientes del francés, lengua en la que es exigida la presencia de un pronombre demostrativo: ceux de Mariana.

7 «Nominatiui \& vocatiui semper poni ante verbo, \& obliqui... post verba» (ILI: 89). 
la sintaxis latina de 1555, con arreglo a las diferentes partes de la oración. De tal manera que vuelve a tratarse de nuevo el orden de cada clase de palabras con respecto a otras. Doergangk, por ejemplo, apunta que el adverbio francés se suele colocar tras el verbo (aunque no faltan excepciones) (ILG: 497) y sobre la negación del español sugiere esta regla: «no ante verbum \& jamas post» (ILH: 273). Aunque esta regla no es exacta con respecto a la posición de la forma jamás, que en los ejemplos parece ser utilizada solo como refuerzo de la negación, la observación debía de ser útil para aprendices de lengua alemana, quienes tenderían a utilizar una doble negación.

\section{La concordancia}

La concordancia y el régimen, a diferencia del orden, no reciben en los distintos tratados un capítulo específico. Con respecto a la concordancia, Doergangk presenta las variaciones morfológicas que resultan de la combinación en el discurso de las diferentes clases de palabras: por ejemplo, en francés, en italiano y en español, el artículo, el sustantivo y el adjetivo han de concordar en género, en número y caso. De la misma manera, en el apartado de sintaxis de los verbos Doergangk trata de la concordancia entre nombre y verbo que se establece en número y persona: «eiusdem numeri \& personae, ut apud latinos» (ILH: 187). La concordancia (o su ausencia) es empleada por Doergangk en alguna ocasión como el recurso que le permite distinguir un elemento de un paradigma de los otros que lo forman. Este procedimiento es el que utiliza para caracterizar qualsivoglia en italiano, pronombre que se diferencia de otros por su ausencia de moción (IL: 88).

También con respecto a la concordancia, como sucede con relación al orden, en las tres gramáticas se detallan las anomalías, los supuestos de ruptura. Así, al mostrar la alteración de la concordancia entre sujeto y verbo, el autor estudia con atención el empleo de pronombres de cortesía en las tres lenguas descritas: $e l$, vos o vuestra merced para referirse al interlocutor que requiere segunda persona. Doergangk no solo señala las posibles variantes del posesivo: vuestra(s), vuessas(s), vueza(s), sino que se extiende en el empleo de los recursos de cortesía verbal que se asocian a determinados actos de habla como el saludo (ILH: 145). Igualmente, en el caso de 
los verbos impersonales españoles, amanece, anochece, haze oscuro, es bueno, etc., el autor destaca que, mientras que italianos, franceses y alemanes emplean un sujeto (egli, il, es) los españoles los construyen como los latinos, sin ningún sujeto explícito.

A pesar de la existencia de reglas tan detalladas, o quizá por ello, el autor no distingue bien cuándo las variaciones tienen lugar como consecuencia de determinaciones semánticas o incluso pragmáticas o cuando son resultado de la simple yuxtaposición de los significantes. Describe, por ejemplo en español, el empleo del artículo $e l$ ante palabras femeninas que comienzan por -a: el antigua Iglesia Romana (ILH: 144) o la alteración de la forma del imperativo más pronombre, escribilde (ILH: 224).

\section{El régimen}

El tercer componente de la sintaxis, nuclear en la descripción del latín y del griego, así como en la de otras lenguas con casos, es el del régimen. Dado que consiste en la descripción del caso que los nombres y pronombres asumen en su combinación con verbos, preposiciones o con otros nombres y puesto que en las lenguas románicas no hay formulación morfológica del caso en el nombre, Doergangk, como otros muchos gramáticos, ${ }^{8}$ supone que el caso es una categoría de naturaleza semántica y se funda en la equivalencia que un nombre o pronombre presenta con las formas casuales latinas en virtud de su significado. Los casos así caracterizados son expresados mediante preposiciones (o mediante su ausencia).

La noción de régimen referida al verbo se vincula en la gramática latina frecuentemente con la noción de transitividad, de manera que se establecen diversas estructuras (en algunos gramáticos denominadas noticias), según las diferentes construcciones de un verbo con acusativo, sin él. No obstante, la mayor parte de las gramáticas latinas entienden que existe régimen en cualquier combinación de diferentes partes de la oración, algo que también acepta Doergangk. De una parte, nuestro autor recoge las combinaciones de dos nombres e incluye ahí, no solo los supuestos casos

8 Doergangk explica cómo entiende el caso y la declinación: «casus cognoscuntur ex structura orationis vel ex his praefixis notis $d e, d u$, des, ̀̀, au, aux» (ILG: 112). 
de dos nombres vinculados, sino también las construcciones partitivas, las de los superlativos y de los comparativos (ILI: 83). De otro lado, el régimen de los verbos se constituye en un componente central. Aparte de los verbos que se construyen con pronombre, son examinadas las construcciones que exigen otros verbos, de los que establece largas clasificaciones según su significado y su régimen preposicional. Esta transposición de las reglas de la gramática latina es aplicada por Doergangk al francés, al italiano y al español: tal como ya había hecho Caucius (1570: 216-222), se detallan los supuestos casos que rige cada verbo, se indica para cada construcción la preposición que corresponde y a la vez se explican los diferentes sentidos (modo, instrumento, causa, parte, etc.) como resultantes del empleo, no solo de la preposición, sino también de ese supuesto caso.

Para Doergangk la rección se extiende incluso a las partes indeclinables de la oración: adverbio, preposición, conjunción e interjección. En cuanto a las conjunciones, observa que siempre vinculan elementos coincidentes en el caso. En las interjecciones, en cada una de las lenguas, cree el autor reconocer diferentes combinaciones casuales, de dativo, acusativo, vocativo. La justificación de tal supuesto régimen casual se deriva de su empleo con preposición o sin ella y se muestra mediante ejemplos: «o regit accusatiuum vel vocatiuum» (ILH: 265); «ay, vae, regit accusatiuum vel ablatiuum», y, más adelante, también vocativo (ILH: 289). En relación con los adverbios igualmente se indica el caso de los nombres con que se combinan: «Aduerbia \& praepositiones quando componuntur cun $a u$, vel quando eis praeponitur au, plerunque regunt genitiuum, ut Allez au devant d'eux» (ILG: 498).

\section{Las reglas de construcción}

Mientras que los primeros tratados destinados a la enseñanza de lenguas modernas extranjeras, como las gramáticas anónimas de Lovaina o el tratado de Vivier (1566), se centraban solo en la presentación de los paradigmas de la morfología, posteriormente se habían ido incluyendo contenidos novedosos o más complejos sobre el artículo (Meigret 1888 [1550]: 26-27, Ramus 1572: 128-134; Ramus 1590: 79-82), el empleo de los pronombres (Caucius 1570: 89 y ss.; H. Estienne 1582: 20-30), los adverbios pronominales (Ramus 1590: 117, Dolce, Ruscelli) (Kukenheim 1932: 
139), las comparaciones y las locuciones adverbiales (Miranda 1998 [1550]: 289-300; Oudin 1597: 156-166) así como los tiempos verbales o las perífrasis. Doergangk, a partir de este acervo descriptivo de las diferentes lenguas que estudia, incorpora a la sintaxis un conjunto de asuntos que no siempre atañen directamente a la construcción. Además su organización de la sintaxis con arreglo a las diferentes partes de la oración le facilita el tratamiento de esos componentes adicionales, pues puede precisar su descripción precisamente cuando trata de la parte de la oración a la que corresponde. El capítulo más destacado redactado con este procedimiento es el del artículo tal como aparece en la gramática francesa. En él el autor pretende estudiar en 21 reglas no solo los empleos del artículo en combinación con muy diversas clases de palabras, sino también el sentido que resulta de su utilización: "Articvli officivm est rem certam denotare, itaque cum infinite \& confusum loquimur non vtimur anrticulo» (ILG: 323). ${ }^{9}$

El gramático advierte que en ocasiones la posibilidad de combinación sintáctica de un elemento no existe para otro relacionado y procura explicar estos hechos en virtud del significado de uno de los constituyentes. Este recurso se utiliza al tratar de los relativos: la descripción de las construcciones en que se puede incluir al relativo cui es el recurso utilizado para caracterizarlo frente a otros como colui. $\mathrm{Al}$ mismo tiempo, la construcción puede ser utilizada por el gramático para establecer los rasgos propios de una clase de palabras o de un constituyente dentro del paradigma al que pertenece. Por ejemplo, la diferencia entre las partículas $v i$, $c i$, ne y los pronombres voi, moi, etc., del italiano es fijada por Doergangk en virtud de su combinación con preposición (ILI: 96-108).

En su examen de las combinaciones sintácticas, Doergangk atiende, de una parte, a aquellas en las que un constituyente modifica el significado de otro, tal como sucede con las preposiciones y el artículo en la construcción con infinitivo: (IL: 94; ILH: 208-210). Pero también se examinan construcciones que dan como resultado unidades con un significado propio diferente de la suma del de sus constituyentes. Es el caso de los pronombres compuestos como esto otro, cual quiera, etc., de los verbos pronominales y de las perífrasis verbales. Sobre los pronombres, Doergangk ya en

9 Frente a lo que sucede en la gramática francesa, en la española las líneas dedicadas al artículo son muy escasas y falta casi por completo su estudio en la gramática italiana. 
las Instituciones sobre el francés establece con extremo cuidado el inventario de las diferentes formas y para cada una de ellas se estudian sus combinaciones con otras partes de la oración. Pero, además de los inventarios, Doergangk presta también atención a las combinaciones de verbo con pronombre átono, redundante o no, de las que aporta numerosísimos ejemplos, si bien no sabe explicar por qué en unos casos se presenta la duplicación pronominal del tipo llegarl llegarse y en otros no (ILH: 194).

Doergangk no siempre distingue adecuadamente reglas de combinación sintáctica en virtud del significado y la función de los constituyentes de lo que son simples variaciones morfológicas resultantes del condicionamiento sintáctico, que no conllevan ningún cambio de significado en los elementos de la combinación. De esta manera describe el apócope de numerales y cuantitativos espańoles como cien, tan, quan, a los que dedica varios párrafos, o el de gran frente a grande. Tampoco separa con claridad lo que es una construcción sintáctica de lo que es un compuesto léxico. La descripción de las posibles construcciones y sus limitaciones alcanza, por ejemplo, a la secuencia de dos adverbios en -mente, de tal suerte que el primero de ellos pierde el afijo: «quando duo adverbi qualitativi in mente coniunguntur tunc a priori tollitur mente» (ILH: 272).

\section{Significado y construcción}

Al considerar la sintaxis como construcción de unas partes de la oración con otras, Doergangk no solo expone los esquemas constructivos existentes, sino que muestra cómo lo que determina esa construcción puede ser el significado de los elementos que la integran. Ciertas construcciones solo se presentan en virtud del significado léxico de uno de sus constituyentes, fundamentalmente el verbo. Este hecho que, en definitiva, es también el que determina los fenómenos de régimen, se tiene muy en cuenta para presentar las construcciones de verbos pronominales y en las tres gramáticas se aportan largas listas de verbos que se construyen con pronombre (ILI: 96; ILH: 194-196).

Además, el gramático observa que de la propia construcción resultan significados particulares. En el caso de las conjunciones, pues, que, para que, aunque, tal como se describen en el apartado titulado «De sintaxis temporum», nuestro autor presenta los modos y tiempos con los que se 
combinan, pero también el significado que resulta de cada construcción. Se trata, así, de un apartado que, en definitiva, viene en gran medida a formular los esquemas y el significado de las oraciones subordinadas. ${ }^{10}$

Un rasgo común a todos estos materiales es que las construcciones se describen, no solo en virtud de los constituyentes que las integran, sino también por el significado que resulta de la combinación. De esta manera, la sintaxis de Doergangk da cabida también a la presentación de los significados, que se producen con los verbos pronominales o las perífrasis verbales. Ha de describir para ello el uso de los auxiliares avoir, être (ILG: 473 y ss.), o haber y tener (ILH: 199) y ser y estar (ILH: 199-203) y explicar las funciones de cada uno de ellos y sus diferencias interlingüísticas. De la misma manera se incorpora en las tres obras la presentación del empleo de los tiempos del verbo y muy especialmente de las equivalencias posibles de los pretéritos con los tiempos del latín y del alemán (ILG: 470; ILI: 106; ILH: 221).

Frecuentemente en la explicación del significado se recurre a las equivalencias con otras lenguas, del latín (por ejemplo, de preposición más infinitivo romance equivale al gerundio latino $)$ o bien del alemán $(a+$ infinitivo se corresponde con $z u$ más infinitivo del alemán; si del italiano, se del español, on del francés se hace equivaler a man del alemán en la expresión de la impersonalidad) (ILI: 104). ${ }^{11}$ Este mismo recurso es utilizado por Doergangk para señalar el valor del italiano esso, frente a otros pronombres, o en la descripción de los pretéritos del italiano y del español frente a al francés. $^{12}$

La sintaxis queda configurada con componentes más complejos, nuevos no solo con respecto a lo que era habitual en gramáticas de lenguas modernas, sino también con relación a lo tradicional en la gramática lati-

10 Es posible que semejante capítulo tenga relación con el que aparece en el libro de sintaxis de Alvares con el título de "coniunctionis constructio», pues en él se recogen combinaciones de conjunciones latinas con formas verbales, así como el sentido que de ello resulta.

11 El empleo de equivalencias de tipo contrastivo se presenta no solo en la caracterización de constituyentes sino también para describir el valor de algunas construcciones (ILH: 214).

12 En el tratado sobre el español, tras haber señalado las equivalencias de los demostrativos y de los relativos con otras lenguas, el latín, el francés o el alemán, lo que hace es poner ejemplos — muy extensos— de su empleo. 
na, pues se formulan las reglas de construcción en virtud del significado y la función de los constituyentes, y esa explicación del significado corresponde no solo a las construcciones en sí, sino a los elementos que las integran. Incluso se piensa necesario dar cuenta en la sintaxis de los significados especiales que resultan en frases hechas y locuciones. La fraseología queda incorporada a la sintaxis.

\section{Resumen y conclusiones}

Las tres gramáticas de Heinrich Doergangk conceden a la sintaxis una extensión que supera ampliamente lo que es habitual en los tratados para extranjeros de fines del siglo XVI y principios del XVII. Las gramáticas de Doergangk definen la sintaxis como la correcta construcción y proporcionan reglas de combinación de las partes de la oración. Los contenidos que son comunes en la gramática latina, el orden, la concordancia y el régimen, se completan en ellas con extensas descripciones de empleos y valores de unidades gramaticales ausentes en la gramática latina, del artículo, los tiempos compuestos y las perífrasis verbales entre otros.

Nuestro autor utiliza tales descripciones e introduce en la sintaxis la presentación del valor de numerosos elementos gramaticales ajenos a la gramática latina y lo hace frecuentemente con carácter contrastivo al comparar la lengua que se describe con el latín, el alemán o con las otras dos lenguas románicas.

De esta manera ya en las tres gramáticas de Doergangk tiene lugar la inclusión en la sintaxis, no solo de las reglas de combinación de palabras, sino también la explicación del significado de las unidades gramaticales proponiendo una extensión de la sintaxis que plantea el problema de sus fronteras con la morfología.

\section{Referencias primarias}

Alvares, M. (1596 [1572]): De Institvtione grammatica libri tres, Olyssipone, excudebat Ioannes Barrerius, Typographus Regius, Comprobae.

CAUciUs, A. (1570): Grammatica gallica, suis partibus absolutior, quam ullus ante hunc diem ediderit, Basileae, per Samvelem Regum, Anno mDLxx. 
DoergangK, H. (1604): Institutiones In Linguam Gallicam: Admodum Faciles, Quales ante hac nunquam visae. Quibus omnes eius linguae difficultates ad viuum quàm luculentissimè resecantur \& dissoluuntur, adeò vt diligens ac generosus proprio eam Marte ex his addiscerè possit. Germanos in primis, qui eius linguae flagrant desiderio, explebunt gaudio, \& reliquis nationibus multum poterunt adferre fructus, imprimebat Ioannes Christophori, sumptibus ipsuismet authoris.

- (1604): Institutiones in linguam italicam admodum faciles, quales antehac nunquam visae. Germanos, Gallos et Hispanos, qui eius linguae flagrant desiderio, repleturae gaudio, \& reliquae nationes valde refocillatura, imprimebat Ioannes Christophori, sumptibus ipsuismet authoris.

- (1614): Institvtiones in lingvam hispanicam ad modvm faciles, qvales ante hac nunquam visae... Coloniae, Petrus à Brachel.

Estienne, H. (1582): Hypomneses de Gallica lingua peregrinis eam discentibus necessariae: quaeda vero ipsis etiam Gallis multum profuturae... Genève, Slatkine reprints.

GarnerIUS, J. (1591): Institvtio gallicae linguae in vsvm ivventvtis germanicae, Geneva, apud E. Vignon.

Meigret, L. (1888 [1550]): Le tretté de la grammere françoese, Louis Meigret, lionies, a París Ches Chrestien Weckel, Neu herausgegeben von Wendelin Foerster, Heilbronn, Gebr. Henninger.

Miranda, G. (1998 [1566]): Osservationi della lingua castigliana, di Giovanni Miranda, divise in quatro libri: ne quali sinsegna con gran facilita la perfetta lengua Spagnuola. Con Privilegio. In Venegia appresso Gabriel Giolito de Ferra$r i$, edición facsímil de la impresión de 1569 y estudio de Juan M. Lope Blanch, Méjico, UNAM.

Nebrija, E. A. de (1996 [ca. 1488]): Introducciones latinas [...] contrapuesto el romance al latín, Zamora, edición de Miguel Ángel Esparza y Vicente Calvo, Münster, Nodus Publikationen.

Oudin, C. (1597): Grammaire et observations de la langue espagnolle, recueillies \& $t$ mises en Francois, Paris, chez Marc Orry.

Ramus, P. [Pierre de la Ramée] (1572): Grammaire, Paris, de l'imprimerie d'André Wechsel.

- (1590): Grammatica latino-francica a Petro Ramo Francice scripta, Latine vero facta. Annotationibusque illustrata, per Pantaleonem Theveninum Commerciensem Lotharingum, editio secunda. Francofurti. Apud Joannem Wechelum.

Vivier, G. du (1566): Grammaire Françoise tovchant la Lecture, declinaisons des Noms \& Coniugaisons des Verbes. Le tout mis en François \& Allemang par Gerard du Vivier Gantois, Maistre d'Escole Françoise, en caste Ville de Coloigne, Devant les Freres Mineurs [M. Cholinum (Gedruckt zü Cöllen)]. 


\section{Referencias secundarias}

Chevalier, J.-C. (1968): Histoire de la syntaxe. Naissance de la notion de complément dans la grammaire française (1530-1750), Ginebra, Librairie Droz.

Kunenheim, L. (1932): Contributions à l'histoire de la grammaire italienne, espagnole et française à l'époque de la Renaissance, Ámsterdam, N. V. NoordHollandsche Uitgevers-Maatschappi.

Ridruejo, E. (2010a): "Miranda, Oudin y Doergangk: relaciones y diferencias», en Carlos Assunção, Gonçalo Fernandes e Marlene Loureiro (eds.), Ideias Linguisticas na Península Ibérica (séc. XIV a séc. XIX), Münster, Nodus Publikationen, vol. II: 755-768.

- (2010b): Las Institutiones in lingvam hispanicam (1614) de Henrich Doergangk, Madrid, Ministerio de Asuntos Exteriores y Cooperación-AECID.

Swiggers, P. (2008): "Las gramáticas españolas de Doergangk, 1614; De la Porte, 1659; y Sobrino, 1697. El foco belga-renano», en J. J. Gómez Asencio (ed.), El castellano y su codificación gramatical II, De 1614; B. Jiménez Patón; a 1697. F. Sobrino, Salamanca, Instituto Castellano y Leonés de la Lengua: 351-386. 


\title{
LA ENSEÑANZA DE LA LENGUA ESPAÑOLA EN EL PLAN VILLALOBOS (1934): CARACTERÍSTICAS, FUNDAMENTOS Y PROYECCIÓN POSTERIOR ${ }^{1}$
}

\author{
María Antonia Martín Zorraquino \\ (Universidad de Zaragoza)
}

\section{El llamado Plan Villalobos (1934): el Bachillerato de la II República Española}

La promulgación de un nuevo Plan de Bachillerato en la II República Española se produjo en 1934, durante el llamado Bienio Conservador, siendo ministro de Instrucción Pública Filiberto Villalobos, de ahí que tales estudios secundarios se conozcan habitualmente como el «Plan Villalobos».

1 Una primera versión del presente trabajo fue leída en el II Congreso sobre el Bachillerato en Aragón celebrado en Zaragoza en abril de 2011. Me ha parecido que el tema refleja muy bien las preocupaciones y las ilusiones que hemos compartido, durante tantos ańos, mi buen amigo José Francisco Val y yo y, por ello, he querido dedicarle estas líneas en este tan merecido Homenaje. Deseo expresar, asimismo, mi gratitud a nuestro amigo y colega Luis Santos Río, catedrático de Lingüística General de la Universidad de Salamanca, que me proporcionó el valioso y extenso catálogo de la exposición Sueños de concordia. Filiberto Villalobos y su tiempo histórico (1900-1955) (cf. Francia Sánchez / Rodríguez de las Heras, eds., 2005), que me ha sido de enorme utilidad para realizar la presente aportación. Vaya mi agradecimiento también al Dr. Guillermo Vicente, organizador del Congreso en cuyo marco presenté la primera versión de este modesto trabajo, por su atento apoyo y estímulo. 
El nuevo Bachillerato (que sustituía al Plan Callejo de 1926) comprendía siete cursos, como este, subdividido en dos ciclos. Seguía el Proyecto de Segunda Enseñanza impulsado por Fernando de los Ríos en 1932 (Hernández Díaz, 2005: 381) y mantenía un decidido eclecticismo entre las humanidades y las ciencias, al tiempo que introducía de nuevo dos idiomas modernos y el estudio de las ciencias sociales en los dos últimos cursos (ibídem).

Como han destacado diversos historiadores y pedagogos, la reforma de la educación fue planteada por el gobierno de la II República desde los comienzos del nuevo régimen, no solo en cuanto una tarea esencial para conseguir la democratización del país, sino también como una herramienta fundamental para la socialización política de sus ciudadanos (cf. Puelles, 1991: 159-160). Para ello, la República, desde los primeros meses de gobierno, promulgó diversos decretos y, sobre todo, plasmó en los artículos 48 y 49 de la Constitución de 1931 las líneas maestras del sistema educativo que postulaba. Puelles (1991) considera, sin embargo, que, a pesar de su ingente esfuerzo y de muchos logros en diferentes ámbitos (aumento espectacular de la creación de puestos de maestros y de la construcción de escuelas; medidas para la formación del profesorado; avance extraordinario en la escolarización de los espańoles; asistencia y protección del medio rural - a través de la escuela y muy especialmente, para los lugares más recónditos, gracias a la actuación de las Misiones Pedagógicas-, etc.), el sistema educativo republicano quedó en un proyecto frustrado.

Tengo para mí, no obstante, que el Plan Villalobos representó, pese a las críticas que ha recibido por parte de algunos estudiosos, una contribución importante para la educación secundaria en España. Y, asimismo, pudo constituir un punto de referencia benéfico al fin de la Guerra Civil.

\section{Características del Plan Villalobos con referencia especial a la enseñanza de la lengua española}

Conviene recordar que Villalobos, un ilustre médico salmantino, gran amigo de Unamuno, y político muy respetado y querido en su tierra, era miembro del Partido Reformista, en el que militó casi toda su vida (Este- 
ban de Vega, 2005: 181-182) y, sin ser propiamente un institucionista ni hallarse en contacto directo con Giner o Cossío, por su amistad con Unamuno y, sobre todo, por su conducta en la educación de sus propios hijos, podemos deducir que conocía bien las ideas institucionistas en materia educativa y que las apreciaba: llevó a su hija Carmen al Instituto-Escuela (fundado en 1918) y esta, más tarde, vivió en la Residencia de Señoritas; Carmen Villalobos fue después (terminada la guerra civil) profesora de Física y Química en el colegio Estudio, dirigido por Jimena Menéndez Pidal (Esteban de Vega, ibídem). De otro lado, Villalobos apoyó, como ministro, a varias de las instituciones y actividades más afines a la Institución Libre de Enseñanza (ILE) (las Misiones Pedagógicas, la Junta para Ampliación de Estudios —Hernández Díaz, 2005: 375 y ss.— y, en particular, el Centro de Estudios Históricos: favoreció la implantación de su Sección de Estudios Clásicos, solicitada con gran empeño por Menéndez Pidal; cf. Pérez Villanueva, 1991: 277). Por otra parte, la actuación de Filiberto Villalobos al frente del Ministerio de Instrucción Pública concitó apoyos, pero también muchas críticas: en el seno de sus adversarios y en el de sus compañeros de coalición, frente a quienes impuso su propio respeto por la escuela pública y laica. Por ello, Preston (2005: 281) lo considera un representante prototípico de la «Tercera Espańa».

Son varios los Decretos que dieron forma a los nuevos estudios: Decreto 26.07.1934 (que regula el sistema de exámenes y determina que los alumnos libres y colegiados han de ir a Institutos Nacionales de Segunda Enseñanza y presentarse ante un tribunal conformado ad casum, y prohíbe que un profesor de segunda enseñanza pueda exigir o imponer los libros de texto o de lectura); Decreto 6.08.1934 (por el que se crean Institutos $\mathrm{Na}$ cionales e Institutos Elementales) y Decreto 29.08.1934, que articula propiamente los estudios (siete cursos en dos ciclos, como en el Plan Callejo de 1926: en primer lugar, un ciclo elemental de tres ańos, que permitiera el enlace con la enseñanza primaria; en segundo lugar, un ciclo superior, de cuatro años, subdividido, a su vez, en otros dos: el primero, con disciplinas eminentemente formativas, y el segundo, más especializado, preparatorio para la Universidad, con tres exámenes de conjunto al término de cada uno de los períodos indicados: elemental, primer ciclo superior y segundo ciclo superior; y, de otro lado, por supuesto - en consonancia con el art. 48 de la Constitución de 1931—, no incluía la religión como materia de clase, hecho que debe subrayarse, ya que le granjeó a Villalobos una fuerte opo- 
sición por parte de muchos de los integrantes y de los partidarios del Gobierno de coalición del que formaba parte en el bienio 1933-1934). Por otra parte, los Cuestionarios de cada materia del Bachillerato se publicaron en la Gaceta de Madrid el 1.10.1934. De entre ellos, me parece de especial interés e importancia el que afecta a la enseñanza de la lengua espańola como lengua materna.

En lo que se refiere a la lengua española y su literatura, el Plan colocaba a la disciplina en el primer lugar del currículo: la declaraba obligatoria en todos los cursos con una gradación cíclica, cuidadosa, de sus contenidos, combinando armónicamente las prácticas de lectura, dictado, redacción, análisis gramatical e iniciación al estudio de los textos literarios a lo largo de los cuatro primeros años, para ir ampliando - y profundizandoprogresivamente, en los tres últimos, el comentario gramatical, la explicación de textos literarios, la disertación literaria, el estudio histórico de la lengua y el de la literatura española en todos sus géneros y periodos, con referencia igualmente a las obras más significativas de la literatura universal (Martín Zorraquino, 1999/2000: 75). En especial, en lo que se refiere a la enseńanza de la gramática histórica de la lengua, como ya he indicado en otro lugar (Martín Zorraquino, 1999/2000: 76):

[...] se incluía en el sexto curso; contaba con una hora semanal que complementaba la otra asignada a la disciplina, destinada al estudio de una serie de autores de la literatura española que habían de elegirse de una lista que comenzaba con el anónimo autor del Cantar del Cid y llegaba hasta Ganivet; la selección de un texto medieval era obligada "para poder practicar el análisis histórico del idioma dentro de los límites elementales que aquí se señalan».

Como señala C. López Ferrero (1997: 17 y ss.), en la etapa republicana que nos ocupa, la enseñanza de la lengua española se concibe como la transmisión y el aprendizaje de una habilidad, un hecho vivo, práctico, separado de la gramática, que implica una abstracción. Este es uno de los principios propugnados por la pedagógica "escuela unificada» y que, a mi juicio, tiene muchos puntos de contacto con el pensamiento de Américo Castro para la enseñanza de la lengua materna (Castro, 1922 y cf. infra) (cf. igualmente, Martín Zorraquino y Cuartero Sánchez, 2005: 1240). Como indica López Ferrero (1997: 19-22), la gramática se empezará a percibir como ciencia lingüística más adelante, entre 1939 y 1956 (en 1951 se publicarán las conocidas gramáticas de Salvador Fernández Ramírez, esencialmente descriptiva, y la de Emilio Alarcos Llorach, de corte 
claramente estructuralista, inspirada en los principios de la glosemática danesa); de hecho, el paradigma estructuralista dará lugar a numerosos libros de texto entre 1956 y 1969, y, a partir de los años setenta se irán incorporando teorías diferentes en la enseńanza de la lengua (gramática generativa, lingüística del texto, pragmática, etc.), hasta llegar a los años finales de la década de los ochenta y, sobre todo, a los ańos noventa del siglo pasado, que han visto renacer de nuevo el interés por la práctica real de la lengua, pero, ahora, en el marco de nuevas teorías sobre la comunicación (López Ferrero, 1997: 22-25).

\section{Fundamentos del Plan Villalobos}

El Plan de 1934 reconocía, así, la importancia capital de la enseñanza de la lengua materna en la formación de los ciudadanos, en consonancia, por ejemplo, con el bachillerato francés (en especial, en lo referente a las técnicas de trabajo para la práctica de la lengua y respecto al estudio de los autores y de las obras literarias). Conviene recordar (cf. Puelles, 1991: 162, n. 11) que la analogía entre la II República española y la III República francesa ha sido suficientemente destacada (no solo en lo tocante a la enseñanza de la lengua materna, por supuesto): Puelles (1991), por ejemplo, insiste en el paralelismo diacrónico que existe en el ámbito de la política de formación de maestros entre el modelo de la República española y el de la francesa:

El modelo francés inspiró, sin duda, el sentido de misión que los republicanos españoles intentaron dar a la formación de los nuevos maestros, auténticos sacerdotes laicos destinados a difundir el nuevo evangelio republicano (ibídem).

De otro lado, el Plan Villalobos simbolizaba el triunfo de las ideas en materia de pedagogía lingüística de algunos de los representantes más conspicuos de la Escuela española de Filología, especialmente don Américo Castro (maestro, por ejemplo, de don Rafael Lapesa y director de su tesis doctoral), claramente vinculado a la ILE, quien, entre 1919 y 1924, había gastado muchas energías, en forma de conferencias, artículos de periódico e incluso libros, para denunciar los graves defectos que presentaba en Espańa la enseñanza de la lengua materna (así como la programación del bachillerato y la organización de las Facultades de Letras), al tiempo que ofrecía orientaciones muy claras para su reforma (cf. Castro, 
1922 y 1924; Martín Zorraquino, 1999/2000). Por otra parte, el Plan Villalobos venía a representar también el triunfo oficial de la Escuela española de Filología en la enseñanza de la Literatura: consagraba la conexión inseparable entre lengua y literatura (sostenía la dimensión creadora de la actividad lingüística) y reconocía la necesidad de la perspectiva histórica para comprender adecuadamente la actividad del hombre (Martín Zorraquino, 1999/2000: 76-77).

En realidad, el Plan Villalobos se inspiraba, y lo respetaba claramente en gran medida, en el Proyecto de Bases para la Segunda Enseñanza que el ministro Fernando de los Ríos había remitido a la Cámara de Diputados en marzo de 1933 (Fernando de los Ríos había leído en dicho lugar el propuesto para la enseńanza primaria el 9 de diciembre de 1932, en el primer aniversario de la Constitución republicana). Y elaboró, igualmente, unas bases para la reforma universitaria.

En lo tocante a la enseñanza secundaria, según destaca Puelles, y como habría de reflejar en buena medida el Plan Villalobos, el Proyecto de Fernando de los Ríos ofrecía una concepción humanista del Bachillerato (según se cita en Puelles, 1991: 169):

El bachillerato ha de aspirar a dotar de una cultura suficiente y sustantiva a quienes terminen este periodo de la enseñanza, mas sus normas pedagógicas no sólo deben proponerse una formación intelectual, sino una edificación de alto valor humano.

De otra parte, siguiendo la mejor tradición del liberalismo español, las Bases presentaban el bachillerato como una prolongación de la enseñanza primaria (no era, pues, una barrera de clase) (ibídem); ofrecía, en fin, tal y como he subrayado, un currículo moderno, ajustado a las tendencias europeas, pues distinguía entre un ciclo de formación básica, común, y un ciclo de semiespecialidad (los tres últimos cursos) y, sobre todo, incluía la enseñanza de idiomas modernos (uno, obligatorio: francés, alemán o inglés) y la de materias de tipo social, como la Economía o el Derecho (preveía, igualmente, enseñanzas complementarias de trabajo manual) (apud Puelles, 1991: 170).

Volviendo al Plan Villalobos, hay que destacar que gozó y, especialmente, ha gozado, con el paso del tiempo, de enorme aceptación, hasta el punto de que ha sido considerado como modélico por su nivel de exigencia 
y racionalidad (Hernández Díaz, 2005: 381). Con todo, ha sido también criticado por algún pedagogo mucho más recientemente (por ejemplo, por Antonio Molero, cf. Hernández Díaz, 2005: 381-382). Así, Molero nos dice (1991: 72-73, cit. también por Hernández Díaz, 2005: ibídem):

El nuevo plan tenía un diseño netamente conservador y clásico, sin ninguna atención al bloque de materias técnico-profesionales ni a las actividades creativas, salvo las alusiones al dibujo y a los juegos y deportes, que sustituían a la educación física de los antiguos planes de enseñanza.

Para Molero (ibídem), el nuevo bachillerato cometía, sobre todo, dos errores considerables: al colocar el ingreso del bachillerato en los diez años, superponía los niveles formativos del nińo, y, especialmente, liquidaba la homologación de los estudios de Magisterio con los de nivel universitario, puesto que los estudiantes de las Escuelas Normales accedían a estas tras el quinto curso del bachillerato (al terminar este, recibían un certificado de estudios elementales de segunda enseñanza válido para el ingreso en aquellas). Por ello, siempre según Molero, los nuevos estudios de bachillerato se ajustaban de nuevo «a una clase social determinada» (ibídem).

La crítica al Plan Villalobos no debe serlo, sin embargo, solo al propio Plan, sino que ha de proyectarse igualmente al Proyecto de Bases de Fernando de los Ríos, pues, como subraya Puelles (1991: 170), «este proyecto, de notables influencias institucionistas, tiene también aspectos negativos, algunos de ellos, incluso desconcertantes».

Para Puelles (lo subraya también Molero para el de Villalobos, según hemos indicado), el bachillerato previsto por de los Ríos (plasmado luego por Villalobos) presentaba el contrasentido político, ideológico y pedagógico de programar el comienzo del bachillerato a los diez años de edad (aun con pasarelas de acceso de la primaria a la secundaria), lo que implicaba una estructura bipolar: algunos nińos seguirían la enseñanza primaria, mientras que otros ingresarían en la enseñanza secundaria y superior, con la creación de facto de dos compartimentos estancos y discriminatorios (Puelles, 1991: ibídem). La motivación de tal desajuste estaba, sin duda, condicionada por los propios presupuestos, los cuales, al parecer, podían garantizar una educación primaria hasta los doce-trece años para todos los españoles, pero, en cambio, no alcanzaban para una educación secundaria con bachillerato. 


\section{Proyección del Plan Villalobos}

Desgraciadamente, el Bachillerato de Villalobos no pudo apenas ponerse en práctica. En el territorio de los sublevados, Pedro Sainz Rodríguez, como ministro de Educación Nacional de Franco, presentó en 1938 un nuevo Plan de Bachillerato, que sería de aplicación al término de la Guerra Civil.

En efecto, el $B O E$ de 23 de septiembre de 1938, en la España de Franco, publicó un nuevo Plan de Bachillerato, que mantenía los siete cursos, pero con un examen final de Estado, ante un tribunal formado por profesores universitarios. Los cuestionarios que desarrollaban la programación de las diversas materias se publicaron, como suplemento del $B O E$ del 14 de abril de 1939 (en el octavo aniversario de la proclamación de la República). Recién terminada la Guerra Civil, los planteamientos de Sainz Rodríguez parecían convertir al estudiante de bachillerato en un hombre del renacimiento español (quizá, más bien, de la Contrarreforma española). La lengua y la literatura españolas habían cedido el puesto a la filosofía y a la religión; se incrementaba considerablemente la presencia de las lenguas clásicas, y planeaba siempre la preocupación por la formación moral del alumno en materia de lecturas: se indicaba explícitamente que se cuidara especialmente que en las obras literarias que habrían de leerse no se reflejaran conductas desviadas, etc. La presencia de la gramática histórica se mantenía, pero, no en el sexto año, sino en el cuarto curso (Martín Zorraquino, 1999/2000: 77, y, sobre todo, n. 29).

El nuevo bachillerato volvía a orientarse casi con exclusividad a las clases medias. Y reflejaba la visión cultural de los vencedores. Sería injusto, con todo, no reconocer que fue obra, en buena medida, de profesores prestigiosos y que quienes lo fueron impartiendo, catedráticos de Enseñanza Media, constituyeron, en su mayor parte, un cuerpo profesional de extraordinario nivel científico y humano. Entre ellos, se encontraban, por ejemplo, en el ámbito de la Lengua y la Literatura espańolas, don Rafael Lapesa, que, precisamente, en 1943, publicó su Formación e historia de la lengua española (cf. Lapesa, 1943) como manual para estudiantes de bachillerato, o don José Manuel Blecua, quien en 1937, y en colaboración con don Rafael Gastón Burillo, había publicado (ajustándose al Plan Villalobos), unas Nociones de gramática histórica española editadas en Zaragoza, Librería General, y destinadas igualmente a los bachilleres. 


\section{Conclusión}

Pues bien, quiero subrayar, como conclusión, que tengo para mí que, más allá de las reservas que suscita el propio Plan de 1938, la existencia de un Plan como el de 1934, el bachillerato de la II República, como referencia precedente, benefició a la formación humanista de los estudiantes y determinó que estos hubieran de adquirir hábitos de trabajo y de valoración del esfuerzo que dieron muy buenos resultados con el tiempo: contribuyeron a formar a grupos sociales de espańoles que hicieron posible, por ejemplo, la Transición, tras la muerte de Franco. Ciertamente, tengo también para mí, que, si el Bachillerato de Villalobos hubiera seguido vigente tras el término de la Guerra Civil, la educación de los jóvenes españoles hubiera bebido en aguas mucho más tolerantes y liberales. Villalobos era un político con profunda dimensión moral, que se comprometía, en su trabajo, con sus semejantes y con las ideas en las que creía sinceramente. Sirva, pues, este modesto trabajo sobre el Plan de Bachillerato que Villalobos sacó adelante en momentos nada favorables a su propio estilo, para rendir homenaje a un lingüista ejemplar, ejemplar no solo en su trayectoria docente e investigadora, sino en la vida diaria: en la rectitud en el obrar y en la generosidad para con los colegas, discípulos y amigos. Gracias, querido Pepe: ad multos annos!

\section{Referencias}

Alarcos Llorach, E. (1951): Gramática estructural (según la Escuela de Copenhague y con especial atención a la lengua española), Madrid, Gredos.

Castro, A. (1922): La enseñanza del español en España, Madrid, Victoriano Suárez.

- (1924): Lengua, enseñanza y literatura (Esbozos), Madrid, Victoriano Suárez. Esteban Vega, M. (2005): «El reformismo educativo y la Institución Libre de Enseñanza en la España del primer tercio del siglo xx», en I. Francia Sánchez / A. Rodríguez de las Heras (eds.), Sueños de concordia. Filiberto Villalobos y su tiempo histórico, 1900-1955, Salamanca, Caja Duero: 181-197.

Fernández Ramírez, S. (1951): Gramática española. Los sonidos, el nombre y el pronombre, Madrid, Revista de Occidente.

Francia Sánchez, I. y A. Rodríguez de las Heras (eds.) (2005): Sueños de concordia. Filiberto Villalobos y su tiempo histórico, 1900-1955, Salamanca, Caja Duero. 
Gastón Burillo, R. y J. M. Blecua (1937): Nociones de gramática histórica española, Zaragoza, Librería General.

Hernández Díaz, J. M.a (2005): «Villalobos, ministro de Instrucción Pública», en I. Francia Sánchez / A. Rodríguez de las Heras (eds.), Sueños de concordia. Filiberto Villalobos y su tiempo histórico, 1900-1955, Salamanca, Caja Duero: 363-390.

LAPESA, R. (1943): Formación e historia de la lengua española. Obra aprobada por el Ministerio de Educación Nacional. Adaptación para Cuarto Año de Bachillerato. Madrid, Librería Enrique Prieto.

López Ferrero, C. (1997): La gramática en la enseñanza secundaria. Las nociones de irregularidad y dependencia en las gramáticas pedagógicas de lengua española (1901-1981): estudio de su transposición didáctica. Tesis doctoral. Universitat Pompeu Fabra, Barcelona (CD-ROM).

Martín Zorraquino, M.a A. (1999/2000): «El legado de aquellos maestros: la enseñanza de la gramática histórica desde el bachillerato. (A propósito de una obra de Rafael Gastón Burillo)", Archivo de Filología Aragonesa. Homenaje a don Antonio Llorente Maldonado, LVI: 63-77.

- y J. M. Cuartero Sánchez (2005): «Educación e historia de las lenguas: dominio español y catalán», en G. Ernst, et al., Romanische Sprachgeschichte / Histoire linguistique de la Romania, Berlín / Nueva York, Walter de Gruyter, II: 1232-1247.

Molero Pintado, A. (1991): Historia de la educación en España. IV. La educación durante la Segunda República y la Guerra Civil, Madrid, Ministerio de Educación y Ciencia (MEC).

Pérez Villanueva, J. (1991): Ramón Menéndez Pidal. Su vida y su tiempo, Madrid, Espasa-Calpe.

Preston, P. (2005): «Filiberto Villalobos y la Tercera España», en I. Francia Sánchez / A. Rodríguez de las Heras (eds.), Sueños de concordia. Filiberto Villalobos y su tiempo histórico, 1900-1955, Salamanca, Caja Duero: 277-297.

Puelles Benítez, M. (1991): «El sistema educativo republicano: un proyecto frustrado", Historia contemporánea, 6: 159-171. 
Este libro

se terminó de imprimir

en los talleres del Servicio de Publicaciones

de la Universidad de Zaragoza

en marzo de 2012

$\mathrm{COCOS}$ 




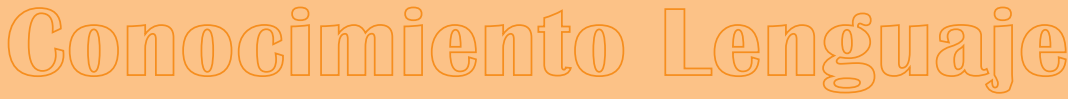 Comunicación

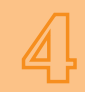

The Knowledge-Language-Communication series has been established in order to provide a forum for discussion on what we know about language; more concretely, on issues such as how we, human beings, acquire this knowledge, how it is used in verbal communication, and what the grammatical mechanisms underlying this system of knowledge and its usage are.

La serie Conocimiento-Lenguaje-Comunicación ha sido creada para proporcionar un foro en el que debatir acerca del conocimiento del lenguaje, sobre cómo los seres humanos adquirimos este conocimiento, cómo se manifiesta en la actividad verbal y cuáles son los mecanismos gramaticales que constituyen la base de ese sistema de conocimiento y su uso.

Observar sin pensar es tan peligroso como pensar sin observar. La hipótesis es nuestra mejor herramienta intelectual.

Santiago Ramón y Cajal

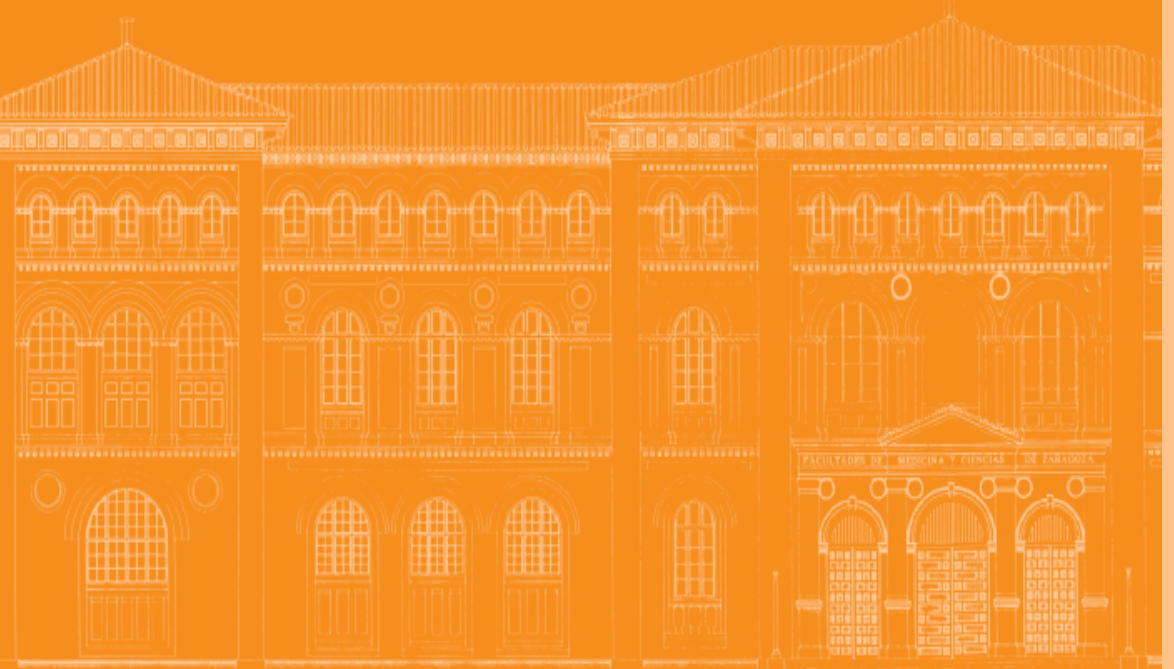

